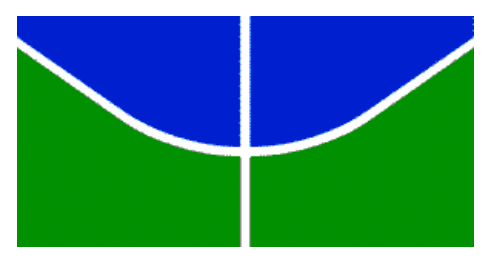

\author{
Universidade de Brasília \\ Instituto de Relações Internacionais \\ Programa de Pós-Graduação em Relações Internacionais
}

\title{
Análise das Relações Comerciais do Brasil com a África durante os governos de Fernando Henrique Cardoso (1995-2002) e Luiz Inácio Lula da Silva (2003-2010)
}




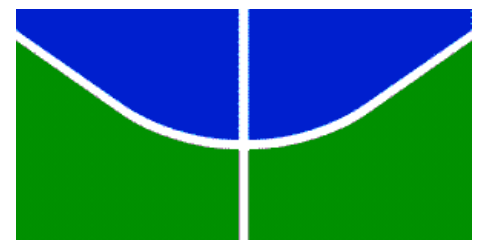

Universidade de Brasília

Instituto de Relações Internacionais

Programa de Pós-Graduação em Relações Internacionais

\section{Análise das Relações Comerciais do Brasil com a África durante os governos de Fernando Henrique Cardoso (1995-2002) e Luiz Inácio Lula da Silva (2003-2010)}

Gislene Nogueira Lima

Dissertação apresentada ao Programa de Pós-Graduação em Relações Internacionais da Universidade de Brasília como requisito parcial para a obtenção do grau de Mestre.

Área: Relações Internacionais - Política Internacional e Comparada.

Orientador: Prof. Dr. Pio Penna Filho

Brasília 


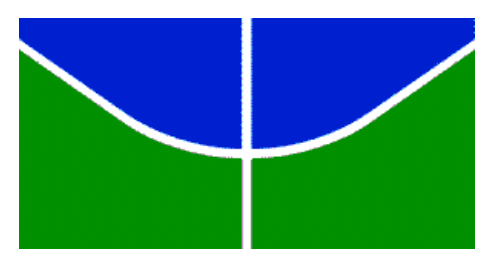

Universidade de Brasília

Instituto de Relações Internacionais

Programa de Pós-Graduação em Relações Internacionais

Defesa da dissertação de mestrado de Gislene Nogueira Lima, intitulada: "Análise das Relações Comerciais do Brasil com a África durante os governos de Fernando Henrique Cardoso (1995-2002) e Luiz Inácio Lula da Silva (2003-2010)", orientada pelo Professor Dr. Pio Penna Filho, apresentada à banca examinadora designada pelo Colegiado do Programa de Pós-Graduação em Relações Internacionais da Universidade de Brasília, em 24 de abril de 2015.

Os membros da Banca Examinadora consideraram a candidata Gislene Nogueira Lima APROVADA

\section{Banca Examinadora:}

Dr. Pio Penna Filho - Instituto de Relações Internacionais da UnB

Dr. José Flávio Sombra Saraiva - Instituto de Relações Internacionais da UnB

Dr. Victor Gomes e Silva - Departamento de Economia da UnB 


\section{AGRADECIMENTOS}

A conquista do título de mestre jamais teria se concretizado sem a força criadora, o amor pela docência, o apoio e a paciência do professor Dr. Pio Penna Filho, meu orientador. Felizes os alunos que, como eu, encontram professores talentosos e generosos pelo caminho acadêmico.

Minha gratidão aos professores da Universidade de Brasília pela oportunidade de conquista de conhecimento. Em nome de todos, agradeço aos professores Dr. José Flávio Sombra Saraiva e ao professor Dr. Victor Gomes e Silva pelos comentários e apontamentos feitos na defesa da minha tese. Obrigada ao professor Roberto Goulart Menezes, pela experiência de um rico estágio de docência.

Agradeço aos meus pais, Maria Mídian e José Arisson, e às minhas irmãs Gisele, Ellen, Elaine e Deise, pela confiança, pela motivação e por tudo o que fizeram e fazem por mim todos os dias. Muito obrigada ao meu marido Saint-Clair e meu filho Lucas, que me deram amor e apoio, mesmo durante as minhas tristes ausências. Eternamente grata à Deus pela luz de todas essas pessoas na minha vida. 


\section{RESUMO}

O objetivo dessa pesquisa é analisar as relações comerciais do Brasil com a África nos governos de Fernando Henrique Cardoso (1995-2002) e Luiz Inácio Lula da Silva (2003-2010). No período analisado, houve um incremento significativo da corrente de comércio entre os dois lados do Atlântico. No entanto, os superávits comerciais do Brasil com o continente africano se transformaram em déficits.

O trabalho apresenta a evolução da balança comercial brasileira com a África, aponta os principais parceiros e mostra o perfil dos produtos exportados e importados. Observa-se que as trocas comerciais têm alta concentração de commodities nos dois lados do comércio. A pesquisa revelou também os principais parceiros e fornecedores do Brasil no continente africano, os produtos mais procurados e os países com os quais o Brasil tem uma balança comercial mais favorável.

O estudo apresenta as características principais da política externa do Brasil para a África. Entre as iniciativas dessa relação multilateral, está a proposta brasileira de perdoar ou renegociar dívidas de países africanos. O levantamento mostrou que as dívidas se referem a compras de mercadorias brasileiras não pagas pelos africanos.

Finalmente, argumenta-se que são inúmeras as oportunidades para o Brasil na África. Rotas marítimas diretas atravessam o Atlântico em direção à África Ocidental. O Brasil tem uma grande oportunidade de conquistar o mercado dos países com os quais tem uma balança comercial deficitária e aproveitar o momento de crescimento econômico experimentado por diversos países africanos. 


\begin{abstract}
The objective of this research is to analyze the commercial relations between Brazil and Africa during the governments of Fernando Henrique Cardoso (1995-2002) and Luiz Inacio Lula da Silva (2003-2010). In the analyzed period, there was a significant increase in trade flow between the two sides of the Atlantic. However, the trade surplus between Brazil and the African continent turned into deficits.

The work presents the evolution of the Brazilian trade balance with Africa, points out the main partners, and disclosure the profile of exported and imported products. It is observed that trade dynamics have high concentration of commodities on both sides. The research also reveals Brazil's key partners and suppliers in Africa, the most sought-after products, and countries with which Brazil has a more favorable trade balance.

The study also presents the main aspects of Brazil's foreign policy towards Africa. Among the initiatives of this multilateral relationship, lies the Brazilian proposal to forgive or renegotiate debts of African countries. The study showed that the debts refer to Brazilian goods purchases not paid by African countries.

Finally, we argue that there are countless opportunities for Brazil in the African continent. Direct sea routes cut across the Atlantic towards West Africa. Brazil has a great opportunity to secure the market of the countries with which it has a deficit trade balance and benefit from the moment of economic growth experienced by many African countries.
\end{abstract}




\section{LISTA GRÁFICOS}

Gráfico 1: Participação do Brasil no Comércio Mundial ..............................................14

Gráfico 2: Evolução do Comércio Exterior do Brasil a partir de 1989 ...............................25

Gráfico 3: Exportações brasileiras por fator agregado (1989-2014)...............................27

Gráfico 4: Participação das exportações para África no total das exportações do Brasil (1995-

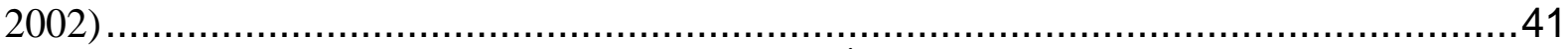

Gráfico 5: Perfil das exportações do Brasil para a África (1995-2002) ............................42

Gráfico 6: As principais commodities vendidas para a África no governo FHC (1997*-2002)

Gráfico 7: Perfil dos principais produtos vendidos para África do Sul (1997-2002) ............48

Gráfico 8: Perfil dos principais produtos vendidos para Angola (1997-2002)....................49

Gráfico 9: Perfil dos principais produtos vendidos para Argélia (1997-2002) .....................49

Gráfico 10: Perfil dos principais produtos vendidos para o Egito $(1997-2002)$...................50

Gráfico 11: Perfil dos principais produtos vendidos para o Marrocos (1997-2002) .............51

Gráfico 12: Perfil dos principais produtos vendidos para a Nigéria $(1997-2002)$..................52

Gráfico 13: A balança comercial do Brasil com os principais compradores de mercadorias na

África: África do Sul, Angola, Argélia, Egito, Marrocos e Nigéria (1995-2002) .................56

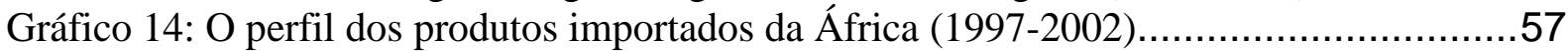

Gráfico 15: As principais commodities compradas da África (1997-2002).......................58

Gráfico 16: A balança comercial do Brasil com a África (1989-2002) ..............................59

Gráfico 17: Participação das exportações para África no total das exportações do Brasil

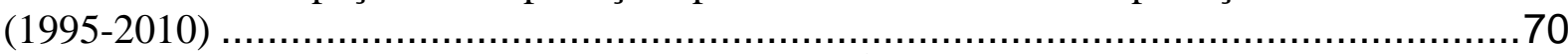

Gráfico 18: Participação das importações feitas da África no total das importações do Brasil

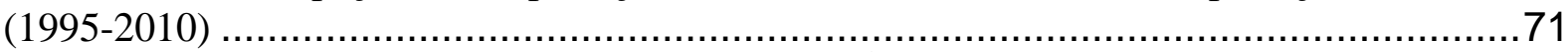

Gráfico 19: Perfil das exportações do Brasil para a África $(1995-2010)$............................72

Gráfico 20: As principais commodities vendidas para a África no governo Lula (2003-2010)

Gráfico 21: Perfil dos principais produtos vendidos para África do Sul (2003-2010) ..........77

Gráfico 22: Perfil dos principais produtos vendidos para Angola (2003-2010) ...................78

Gráfico 23: Perfil dos principais produtos vendidos para Argélia $(2003-2010) \ldots \ldots \ldots \ldots \ldots \ldots . .78$

Gráfico 24: Perfil dos principais produtos vendidos para o Egito $(2003-2010) \ldots \ldots \ldots \ldots \ldots \ldots . . . . .79$

Gráfico 25: Perfil dos principais produtos vendidos para o Marrocos $(2003-2010)$..............81

Gráfico 26: Perfil dos principais produtos vendidos para a Nigéria (2003-2010) ................81

Gráfico 27: A balança comercial do Brasil com os principais compradores de mercadorias na

África: África do Sul, Angola, Argélia, Egito, Marrocos e Nigéria (2003-2010) ................85

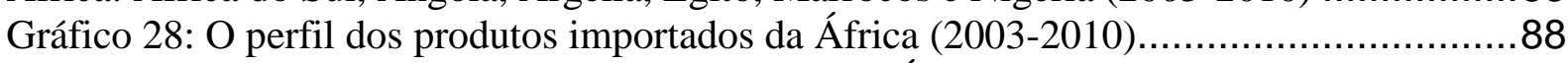

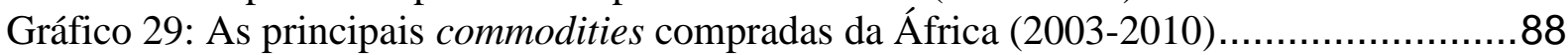

Gráfico 30: Principais mercados de destino das exportações brasileira em $2010 \ldots \ldots \ldots \ldots \ldots \ldots . . . . . . .89$

Gráfico 31: Principais mercados fornecedores do Brasil em 2010.................................89

Gráfico 32: A balança comercial do Brasil com a África (1989-2010) .............................90

Gráfico 33: O avanço da corrente de comércio entre o Brasil e a África (1995-2010) ..........91

Gráfico 34: Os dez principais compradores de mercadorias da África no mundo (US\$

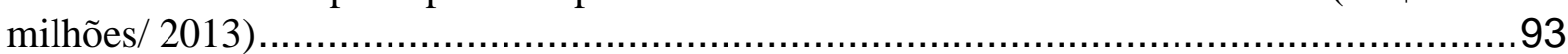

Gráfico 35: Os principais países de origem de produtos comprados pela África (US\$ milhões/

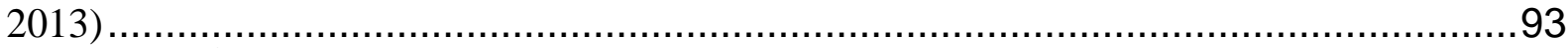

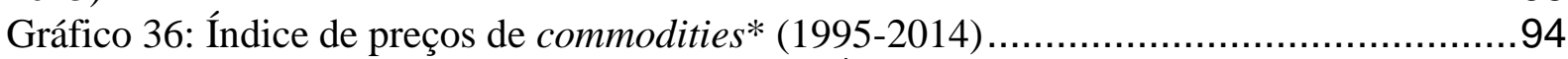

Gráfico 37: A balança comercial do Brasil com a África (1989-2014) ............................97

Gráfico 38: Participação das exportações para África no total das exportações do Brasil 
(1995-2014)

Gráfico 39: Participação das importações feitas da África no total das importações do Brasil (1995-2014)

Gráfico 40: Perfil das exportações do Brasil para a África (1995-2014) 100

\section{LISTA DE TABELAS}

Tabela 1: Exportações Brasileiras por tipo de produto (1940-1999) ...............................23

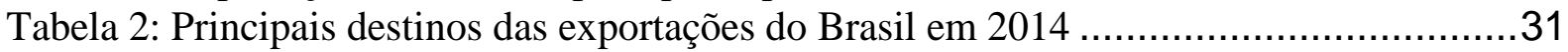

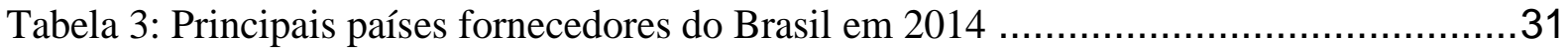

Tabela 4: Principais mercados fornecedores do Brasil em 2014....................................32

Tabela 5: Viagens do presidente Fernando Henrique Cardoso à África ............................35

Tabela 6: Número de resoluções referentes à renegociação de dívidas de países com o Brasil

Tabela 7: Descrição das dívidas de países da África com o Brasil negociadas pelo presidente

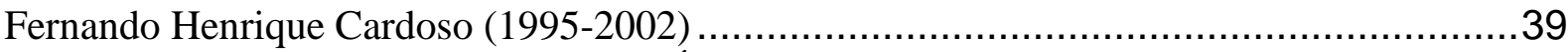

Tabela 8: O comércio entre o Brasil e a África nos anos de governo FHC (1995-2002) .......40

Tabela 9: Perfil das exportações do Brasil para a África em porcentagem (1995-2002).......42 Tabela 10: Lista dos vinte produtos mais vendidos para a África no governo FHC (1997*_

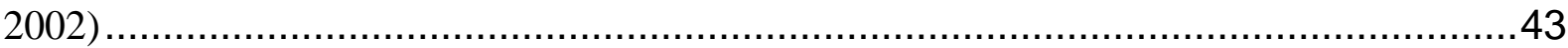

Tabela 11: Os cinco principais destinos das mercadorias brasileiras na África entre $1995 \mathrm{e}$ 2002 / Valores de exportação em dólar (US\$ FOB) ...................................................46

Tabela 12: Lista dos principais produtos vendidos para África do Sul (1997-2002) ............48

Tabela 13: Lista dos principais produtos vendidos para Angola (1997-2002) ....................49

Tabela 14: Lista dos principais produtos vendidos para Argélia (1997-2002).....................50

Tabela 15: Lista dos principais produtos vendidos para o Egito (1997-2002) .....................51

Tabela 16: Lista dos principais produtos vendidos para o Marrocos $(1997-2002)$................52

Tabela 17: Lista dos principais produtos vendidos para a Nigéria (1997-2002) .................53

Tabela 18: Os cinco principais mercados fornecedores do Brasil na África entre 1995 e 2002.

Valores de importação em dólar (US\$ FOB) .......................................................55

Tabela 19: Os dez principais produtos importados da África pelo Brasil (1997-2002) ........57

Tabela 20: Viagens do presidente Luiz Inácio Lula da Silva à África ..............................64

Tabela 21: Descrição das dívidas da África com o Brasil negociadas pelo presidente Luiz

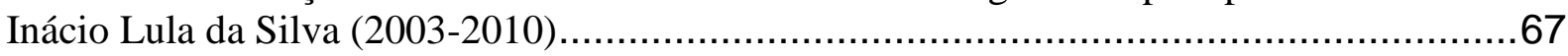

Tabela 22: Descrição de valores de dívida, perdão e reescalomento de dívidas de países da

África com o Brasil / Luiz Inácio Lula da Silva $(2003-2010)$......................................68

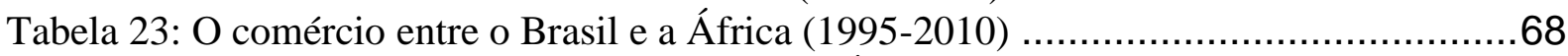

Tabela 24: Perfil das exportações do Brasil para a África $(1995-2010)$.............................72

Tabela 25: Lista dos vinte produtos mais vendidos para a África no governo Lula (2003-2010)

Tabela 26: Os cinco principais destinos das mercadorias brasileiras na África entre 2003 e 2010 / Valores de exportação em dólar (US\$ FOB) ........................................... 76

Tabela 27: Lista dos principais produtos vendidos para África do Sul (2003-2010) ............77

Tabela 28: Lista dos principais produtos vendidos para Angola (2003-2010) ....................78

Tabela 29: Lista dos principais produtos vendidos para Argélia $(2003-2010) \ldots \ldots \ldots \ldots \ldots \ldots \ldots . . . . . .79$

Tabela 30: Lista dos principais produtos vendidos para o Egito $(2003-2010)$..................... 80

Tabela 31: Lista dos principais produtos vendidos para o Marrocos (2003-2010) ...............81

Tabela 32: Lista dos principais produtos vendidos para a Nigéria (2003-2010) ..................82 Tabela 33: Os cinco principais mercados fornecedores do Brasil na África entre 2003 e 2010. 
Valores de importação em dólar (US\$ FOB)

Tabela 34: Balança comercial do Brasil com a África para todos os países e também o total sem Argélia e Nigéria (2003-2010)

Tabela 35: Os dez principais produtos importados da África pelo Brasil (2003-2010) ........87

Tabela 36: O comércio com a África nos anos FHC, Lula e Rousseff (1995-2014)..............96

Tabela 37: Perfil das exportações do Brasil para a África (1995-2014) ............................99

Tabela 38: Descrição das dívidas da África com o Brasil negociadas pela presidente Dilma

Rousseff (2011-2014)

Tabela 39: Descrição de valores de dívida, perdão e reescalomento de dívidas com o Brasil /

Dilma Rousseff (2011- )

\section{LISTA DE FIGURAS}

Figura 1: Rota de transporte marítimo operada pela Maersk Line ...............................28

Figura 2: Rota de transporte marítimo operada pela Nile Dutch ..................................29

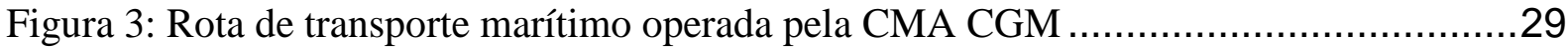

Figura 4: Rota de transporte marítimo operada pela Hamburg Süd ................................30 
ÍNDICE

INTRODUÇÃO 11

1. O BRASIL NO COMÉRCIO COM O MUNDO E COM A ÁFRICA..........................14

2. O COMÉRCIO EXTERIOR DO BRASIL COM A ÁFRICA NO GOVERNO FERNANDO HENRIQUE CARDOSO (1995-2002).

3. O COMÉRCIO EXTERIOR DO BRASIL COM A ÁFRICA NO GOVERNO LUIZ INÁCIO LULA DA SILVA (2003-2010) 61

4. OS INDICATIVOS DO COMÉRCIO EXTERIOR DO BRASIL COM A ÁFRICA NO PRIMEIRO MANDATO DE DILMA ROUSSEFF (2011-2014) . .96 CONCLUSÕES. 104 REFERÊNCIAS BIBLIOGRAFIAS .110 


\section{INTRODUÇÃO}

O comércio exterior entre Brasil e África cresceu mais de sete vezes entre 1995 e 2010, o que significou uma elevação de 659\%; a corrente de comércio passou de US\$ 2,7 bilhões para US\$ 20,5 bilhões. O crescimento do comércio Brasil-África foi superior ao observado no comércio exterior brasileiro como um todo, aumentando o peso relativo da África como parceiro comercial. No mesmo período, as trocas do Brasil com o mundo avançaram em percentual inferior, a soma de exportações e importações passou de US\$ 96,4 bilhões para US\$ 383,6 bilhões, o que representa uma elevação de 298\% (BRASIL, 2014a).

O incremento do comércio exterior entre o Brasil e a África coincidiu com o impulso da diplomacia brasileira na direção do continente africano. A expansão do comércio bilateral e a criação de um número suplementar de embaixadas do outro lado do Atlântico explicitaram os ganhos das iniciativas brasileiras no sentido de mover energias para a nova África (SARAIVA, 2013). O período de maior impulso do comércio internacional com os africanos aconteceu concomitantemente com a transição de governo de Fernando Henrique Cardoso para Luiz Inácio Lula da Silva, quando houve uma mudança no modelo de inserção internacional do Brasil. Naquele momento, a sociedade brasileira assistiu a uma correção de rumos da ação externa compreendida por três linhas de frente: a orientação da política externa para a conquista da reciprocidade real nas relações internacionais, portanto, uma transição para o multilateralismo de reciprocidade entre países centrais e emergentes; o enfrentamento das dependências estruturais do país; e a implementação da proposta de reforçar a América do Sul como polo de poder e plataforma política e econômica de realização de interesses brasileiros (CERVO, 2008).

A corrente de comércio entre o Brasil e a África assistiu a um aumento significativo a partir de 2003, quando houve um salto das trocas comerciais em Free on Board (FOB), a contabilização do valor em dólar exportado até o momento da entrega da mercadoria para o embarque, pronta para transporte, no porto indicado pelo comprador. O resultado positivo desse comércio, no entanto, que era favorável ao Brasil, se alterou. No decorrer do período em estudo, a balança comercial entre a África e o Brasil passou a ser deficitária para os brasileiros. Em 1995, as exportações brasileiras suplantaram as importações da África em US\$ 405 milhões de dólares; ao longo dos últimos anos, no entanto, esse fluxo tomou sentido inverso. O intercâmbio comercial, no fim do governo Luiz Inácio Lula da Silva, caracterizou-se por uma balança comercial deficitária com a África em US\$ 2,03 bilhões. 
Outro ponto relevante neste estudo é o perfil dos produtos comercializados, com grande concentração de commodities, produtos básicos como açúcar, cereais e petróleo (MAIA, 2013). A composição da pauta de produtos importados pelo Brasil também parece concentrada em itens essencialmente básicos, como petróleo bruto. Esse tipo de comércio, caracterizado pelo baixo valor agregado, indica uma perda de oportunidade para as indústrias africanas que poderiam se beneficiar em um nível muito mais apropriado para suas economias caso o perfil exportador fosse de mais ênfase em produtos manufaturados. O equivalente a $85 \%$ das importações brasileiras se refere a petróleo; enquanto mais de 50\% das importações da África consistem em alimentos: açúcar, carne e cereais (VIEIRA, 2011).

Todavia, um dos principais fatores a intrigar observadores é a constatação de que as exportações brasileiras não se diferenciaram consideravelmente, em natureza, dos produtos comprados da África, essencialmente, mercadorias não industrializadas. Na perspectiva de um Estado como o Brasil que dedicou décadas no esforço de um paradigma desenvolvimentista na sua política externa, a expectativa de muitos analistas seria de que o país conseguisse exportar para o mercado africano um percentual significativo de produtos manufaturados. Um dos apelos mais fortes da política brasileira pró-África é que o Brasil exportaria produtos industrializados a preços competitivos. Em países desenvolvidos, a parcela de manufaturados na pauta de exportações representa em grande parte a posição do país na divisão internacional do trabalho (VIEIRA, 2011). Hoje, no entanto, o perfil da balança comercial revela que o Brasil não tem aproveitado a aproximação diplomática com os africanos para abrir mercado para os produtos da indústria.

Os capítulos a seguir analisam o comércio exterior do Brasil com a África nos governos Fernando Henrique Cardoso (1995-2002) e Luiz Inácio Lula da Silva (2003-2010). Apesar de não ser a proposta deste estudo analisar também o governo que sucedeu a Lula, o trabalho traz um breve acréscimo com os indicativos do primeiro mandato de Dilma Rousseff (2011-2014). Outro elemento relevante para o estudo exploratório foram os anúncios de perdão e reescalonamento de dívidas africanas, feitos por Cardoso, Lula e Rousseff. Todas as dívidas eram originárias de convênios de crédito para a exportação de bens e serviços brasileiros, firmados desde os anos 1970.

A prática do perdão de dívidas e a ênfase dada para o relacionamento comercial com a África coincidiram também com a aproximação política entre os atores estatais. A busca por um estreitamento de laços com a África aconteceu no mesmo momento em que o Brasil se interessava em expandir sua inserção internacional, aumentar sua participação em fóruns e 
instituições internacionais, como a Organização Mundial do Comércio (OMC) e o Fundo Monetário Internacional (FMI). Nesse sentido, os votos dos países africanos na eleição do brasileiro Roberto Azevêdo para a direção-geral da OMC, em 2013, pareceram indicar uma bem sucedida política diplomática construída entre o Brasil e a África. O apoio maciço dos países africanos foi considerado decisivo para que o brasileiro saísse vitorioso da disputa. 


\section{O BRASIL NO COMÉRCIO COM O MUNDO E COM A ÁFRICA}

Historicamente o Brasil participa pouco do comércio mundial. As estatísticas da Organização Mundial do Comércio mostram que o país concentra menos de dois por cento de participação nas exportações e importações mundiais desde 1948. O desempenho do Brasil no mercado global revela que o percentual de exportações e importações brasileiras sofreu queda a partir dos anos 1950 e não voltou ao mesmo patamar de antes. Apesar de pequenas oscilações registradas nos anos seguintes, o comércio exterior brasileiro fechou a década de 2010 com menos de 1,5\% das exportações e importações mundiais (OMC, 2014).

Gráfico 1: Participação do Brasil no Comércio Mundial

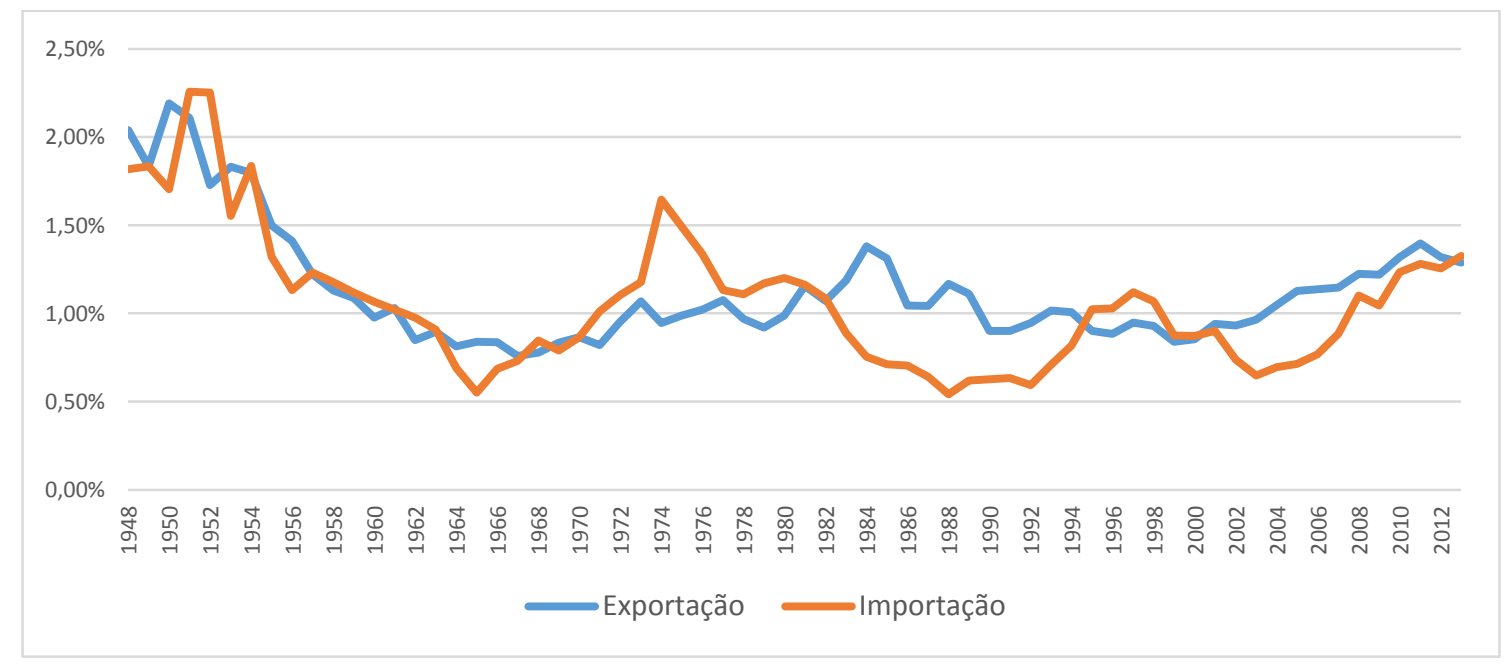

Fonte: Elaboração própria a partir de dados da Organização Mundial do Comércio (OMC, 2014).

O Brasil ocupa apenas a vigésima segunda posição entre os principais exportadores mundiais. Em 2012, a participação brasileira nas vendas de mercadorias alcançou o percentual de 1,3\%. O índice deixou o país atrás do México, que conquistou naquele ano 1,6\% da fatia de mercado global. Os três principais exportadores, China, Estados Unidos e Alemanha, têm sozinhos quase um terço do mercado internacional, 27,3\%. Entre os países à frente do Brasil, ainda estão Coreia do Sul, que detém 3,0\% das vendas internacionais; Rússia com 2,7\% das exportações; e Índia com 1,6\% do comércio de mercadorias pelo mundo (BRASIL, 2013g).

Além de participar pouco do comércio mundial, o Brasil exporta proporcionalmente poucos produtos de alta tecnologia e se destaca como importante fornecedor de commodities para o mercado internacional. O Ministério do Desenvolvimento, Indústria e Comércio Exterior 
utiliza o conceito de fator agregado para classificar os produtos exportados. Dessa forma, o perfil das exportações se divide em três grandes classes. São elas:

a) Produtos básicos: têm baixo valor agregado, normalmente intensivo em mão-de-obra. A cadeia produtiva é geralmente simples e envolve poucas transformações e não há agregação de valor. Nesse grupo estão minério de ferro, grãos e demais produtos da agricultura.

b) Produtos semimanufaturados: são aqueles que passaram por alguma transformação no processo produtivo. Entre eles estão açúcar em bruto e madeira serrada ou cortada. Alguns semimanufaturados são commodities beneficiadas, produtos submetidos a pequenos processos de beneficiamento industrial, como açúcar em bruto, celulose, alumínio em bruto, ouro não monetário (ASSOCIAÇÃO DE COMÉRCIO EXTERIOR DO BRASIL, 2012).

c) Produtos manufaturados: mercadorias caracterizadas pela incorporação de tecnologia, com algum valor agregado. Por exemplo, televisão, computador e avião. Fazem parte também deste grupo, algumas commodities industrializadas, como açúcar refinado, suco de laranja, óleos combustíveis, gasolina. As commodities beneficiadas e industrializadas, diferentemente dos produtos de alta tecnologia, como aviões, não oferecem abertura ao exportador brasileiro na negociação de preços de exportação, uma vez que são eles fixados em bolsas de mercadorias ou pelo mercado internacional (ASSOCIAÇÃO DE COMÉRCIO EXTERIOR DO BRASIL, 2012).

d) Operações especiais: transações especiais de comércio exterior, como compras em free-shop, bagagens provenientes de mudanças, e combustíveis para abastecimento de embarcações e aeronaves em viagem internacional, além de produtos para uso e consumo de bordo (ASSOCIAÇÃO DE COMÉRCIO EXTERIOR DO BRASIL, 2012).

A dependência da exportação de produtos básicos tem longa trajetória na história do Brasil. A economia primário-exportadora era a base do sistema colonial. Nós séculos XVI, 
XVII e XVIII, o país tinha uma economia primário-exportadora conduzida por ciclos de exportação de produtos coloniais: o da cana de a açúcar e, mais tarde, o da mineração de ouro e diamantes (GONÇALVES, 2013. p. 10). Durante o período colonial, Portugal proibiu a produção de bens manufaturados até o século 18, quando a metrópole permitiu a tecelagem para sacos e roupas dos escravos (CARDOSO, 1990, apud GONÇALVES, 2013, p. 11). Estimativas apontam que três commodities respondiam por quase $90 \%$ das exportações do país no período colonial: 56\% de açúcar, 32\% de ouro e diamante (SIMONSEN, 1937, apud GONÇALVES, 2013, p. 12).

O modelo de economia primário-exportadora foi mantido mesmo com a série de transformações políticas, econômicas, sociais e institucionais que o Brasil atravessou depois de sua independência. Os produtos exportados, no entanto, foram sendo substituídos pelo café. O Brasil experimentou, no início do século XIX, o declínio na produção de produtos primários como resultado da queda do preço internacional das principais commodities exportadas. A decadência da economia agroexportadora tradicional foi acompanhada pela expansão da lavoura de café no Rio de Janeiro e, posteriormente, em São Paulo. A quantidade média de sacas exportadas cresceu de pouco mais de 200 mil, entre 1821 e 1825, para mais de 2,5 milhões entre 1851 e 1855. Em 1830, o café superou o açúcar como principal produto exportado pelo Brasil (IBGE, 1990, apud GONÇALVES, 2013, p. 13).

O processo de independência, na verdade, marcou um período em que os dirigentes que se apropriaram do aparato do Estado, plantadores e exportadores de produtos agrícolas ou exploradores de minérios, mantiveram um esquema de portas abertas concebido pelos dirigentes europeus. $\mathrm{O}$ modelo, que se caracterizava pela exportação primária e importação industrial, garantia vantagens para ambos os lados. Para o centro, assegurava a expansão do capitalismo industrial. Na periferia, protegia o domínio da sociedade por uma pequena elite social (CERVO, 2008a, p. 42). As características gerais da economia, entre 1808 e 1930, eram as de um Estado controlado pelo consórcio de latifundiários escravistas, fossem eles usineiros, cafeicultores, plantadores de algodão ou pecuaristas. Essa conjuntura retardou o advento de um capitalismo industrial (PIRES; SOUZA, 2010, p.28).

A Primeira Guerra Mundial e a Grande Depressão de 1929 prejudicaram o comércio exterior não só do Brasil, mas de toda a América Latina. A guerra atrapalhou o fornecimento externo de manufaturados e a depressão atingiu fortemente as exportações primárias de alimentos. As perturbações do comércio exterior causaram impacto no sistema produtivo, que precisou se voltar para a industrialização. Internamente, a crise também significou a mudança 
no controle do poder local, que passou das oligarquias agroexportadoras para as novas elites urbanas, em um processo que fortaleceu o Estado e o seu papel econômico (CERVO, 2008b, p.152).

Foi apenas a partir da década de 1930 que o Brasil experimentou a guinada de sua indústria. Sob o impacto da grande crise de 1929, o país precisou produzir internamente o que antes era importado. O estrangulamento externo, a queda do valor das exportações, gerado pela crise internacional, terminou por forçar o processo de industrialização por substituição de importações, forma predominante da industrialização brasileira. A produção para o mercado interno passou a ser o centro dinâmico da economia (PIRES; SOUZA, 2010, p. 59). Para Gonçalves (2013), a revolução de 1930 foi o ponto de inflexão na trajetória política e na formação econômica do Brasil. Na esfera econômica, a década da ascensão de Getúlio Vargas ao poder marcou a transição da economia agroexportadora para a industrial (GONÇALVES, 2013, p.33).

O Estado, a partir de 1930, passou a representar um papel crescente na economia. A recuperação da crise econômica e a industrialização dependeram, em parte, de um conjunto de iniciativas estatais. Por causa da grave situação das contas externas, o governo decretou monopólio do câmbio, o que também contribuiu para dificultar as importações e, dessa forma, criar condições favoráveis ao desenvolvimento industrial (CANO, 1985, p.173-174, apud CORSI, 2010, p.68). Para acelerar a modernização, o governo isentou de tarifas as importações de equipamentos para setores industriais considerados importantes. Também foram instituídas uma reforma tributária protecionista e uma mudança educacional para incentivar o desenvolvimento de cursos técnicos. A política industrializante amadureceu à medida que a década avançou (CORSI, 2010, p.70).

O fim do Estado Novo de Vargas implicou em uma guinada liberal implementada pelo governo de Eurico Gaspar Dutra. A política econômica do governo Dutra estava centrada no combate à inflação. O governo extinguiu os organismos de controle da economia e abandonou o Plano de Obras e Equipamentos, criado em 1943, para fomentar a indústria de base. O imposto sobre operações cambiais, que fornecia recursos para o fundo de investimento em obras, também foi extinto. As empresas estatais, no entanto, não foram privatizadas, como sugeriam os liberais. As propostas de Dutra buscaram diversificar a economia mantendo o equilíbrio entre agricultura e indústria. A política econômica do governo estava preocupada com os problemas da expansão de infraestrutura e do setor industrial, especialmente no que se refere à energia e aos transportes. Na tentativa de atrair recursos externos, o Brasil baniu a legislação nacionalista 
do Estado Novo, mas nem assim conseguiu atrair capitais externos em montantes significativos. Pelo contrário, o câmbio valorizado acabou por estimular a saída de capitais (CORSI, 2010, p.101-111). Durante os anos de Dutra na presidência da República, a incipiência industrial ainda se refletia em uma pauta de exportações bastante centrada em bens primários. A partir de 1947, a industrialização ascendeu à condição de política governamental de desenvolvimento (CARDOSO, 2013, p. 166-167). O Brasil retomou o viés nacionalista de desenvolvimentista, depois de desiludir-se com as falsas prebendas do mundo liberal (SARAIVA, 2008, p. 226).

Eleito para ocupar novamente a presidência, Getúlio Vargas recuperou o programa econômico do Estado Novo com a incorporação de novos mecanismos. O desenvolvimento da indústria pesada era ponto central, no mesmo tempo em que o governo tentava enfrentar o surto inflacionário e um problemático balanço de pagamentos. A política industrializante tomaria corpo com o lançamento do Plano Nacional de Reaparelhamento Econômico, que previa investimentos na indústria de base, na modernização da agricultura e nos setores de energia e transporte e do Plano Nacional de Eletrificação era ambicioso e previa a duplicação da capacidade instalada do país em dez anos, a implantação da indústria de equipamento elétrico pesado e a criação da Eletrobras com a tarefa de coordenar os investimentos, os financiamentos e as empresas regionais de eletricidade. Finalmente, o projeto de criação da Petrobras pretendia incentivar o desenvolvimento de um setor considerado vital para a economia. Fazia também parte do programa uma série de empreendimentos estratégicos, entre eles o da Companhia Siderúrgica Nacional (CSN) e da Companhia Vale do Rio Doce (CORSI, 2010, p. 117-118). Para dar sustentação financeira aos programas, Vargas assinou a criação do Banco Nacional de Desenvolvimento, o BNDE, atualmente Banco Nacional de Desenvolvimento Econômico e Social (BNDES), em 1952, que passou a desempenhar um papel de destaque na industrialização do país (CARDOSO, 2013, p. 166-168).

Sob a influência de Raúl Prebisch e da Comissão Econômica para a América Latina, a Cepal, os teóricos estruturalistas sustentavam que a desvalorização dos bens primários em relação aos industriais, chamadas por eles de deterioração dos termos de troca, tornava a industrialização substitutiva de importações o único caminho para superar o subdesenvolvimento e as frequentes crises cambiais (CARDOSO, 2013, p. 172-176). Quando Juscelino Kubitschek ganhou as eleições para presidente, ele manteve e aprimorou as propostas de Vargas. O Plano de Metas lançado por ele representou uma das mais amplas ações do Estado na economia ao propor soluções para o estrangulamento nos setores de energia e transportes, e ainda, a criação de um parque industrial mais integrado. O plano visava ao desenvolvimento da 
indústria de base, de bens de intermediários e bens de consumo duráveis. A política petrolífera pretendia substituir as importações de derivados de petróleo com a instalação de pontos de refino no país (CORSI, 2010, p. 131-138).

As políticas cambiais e tarifárias foram usadas como instrumento do desenvolvimento. Para proteger a indústria nacional, o governo tornou ainda mais restritivas as importações de produtos que tinham similares nacionais. Uma lei de tarifas aduaneiras ampliou as taxas em até $150 \%$ para diferentes categorias de produtos. Simultaneamente, facilitava-se a importação de máquinas, matérias-primas e equipamentos para setores considerados prioritários (CORSI, 2010, p. 131-138). Contudo, também durante os anos de governo de Kubitschek, a visão estruturalista se associou à monetarista, que defendia a expansão monetária, e menosprezava o impacto nefasto da inflação na eficiência da economia. Quando Jânio Quadros assumiu a presidência, herdou um país à beira da bancarrota cambial e com inflação crescente (CARDOSO, 2013, p. 168-169).

A despeito do retrocesso democrático e político que representou o Golpe de 1964, o paradigma desenvolvimentista permaneceu vigente. Para Cervo, a vertente desenvolvimentista vai de 1930 a 1989 e, durante décadas, a ideologia foi unanimidade, apesar de alguma divergência no entendimento político. O desenvolvimento associado às forças externas do capitalismo, de vínculos políticos e econômicos com a matriz do sistema, os Estados Unidos, foi tido como recomendável por Eurico Gaspar Dutra, Castelo Branco, Fernando Collor de Melo e Fernando Henrique Cardoso. Por outro lado, o desenvolvimento autônomo, criador de autonomia política e de forte núcleo econômico foi considerado aconselhável por Getúlio Vargas, João Goulart, Ernesto Geisel. Cervo (2008, p. 73-74) considera o presidente Luiz Inácio Lula da Silva uma síntese das duas perspectivas.

O primeiro presidente militar Humberto Castello Branco implementou um abrangente plano de estabilização. O Programa de Ação Econômica do Governo (Paeg) começou a dar resultado a partir de 1968, quando o desenvolvimento industrial experimentou um crescimento vigoroso durante uma década e meia. Esses anos entraram para a história como o tempo do milagre econômico brasileiro, quando o crescimento esteve também associado a alguma redução da inflação e do desequilíbrio externo. O Paeg conseguiu diagnosticar que o modelo de crescimento em um ambiente inflacionário tinha se exaurido. As medidas pretendiam equacionar a restrição do balanço de pagamentos, reduzir a inflação e criar condições institucionais favoráveis à retomada do crescimento econômico. Mesmo com a substituição de presidentes militares, a orientação foi seguida sem grandes desvios até 1973, pelos governos de 
Arthur da Costa e Silva e Emílio Garrastazu Médici. A despeito do aperto monetário e fiscal, contudo, o Paeg não cumpriu as metas estabelecidas. A inflação diminuiu o ritmo, mas ainda assim era alta. O IGP era de 92\% em 1964, ficou em 34\% em 1965 e fechou 1966 em 39\% (HERMANN, 2011, p. 49-54). A política resultou em um crescimento acelerado da economia, no entanto, muitas distorções se acumularam. A inflação gerava entraves à capitalização das indústrias, dificultava a programação financeira das empresas e corroía a arrecadação tributária. Os problemas dificultariam, mais adiante, a manutenção do modelo (CARDOSO, 2013, p. 172176).

O ministro da Fazenda de Médici, então professor de economia da USP, Antonio Delfim Netto, tentou conciliar o combate à inflação com as políticas de incentivo à retomada do crescimento econômico. A reorientação atendia à demanda do governo militar que tentava se legitimar no poder como uma melhor alternativa para o país que a do governo deposto. Em 1968, em mais uma tentativa de estabilizar os preços e motivar o crescimento do país, o governo lança o Plano Estratégico de Desenvolvimento (PED), que tinha como prioridade, além do combate à alta dos preços, o fortalecimento das empresas privadas, a consolidação da infraestrutura e a ampliação do mercado interno com vistas à sustentação da demanda de bens de consumo, principalmente os duráveis. O PED era um plano nitidamente mais desenvolvimentista, acompanhado de previsão de investimentos públicos e políticas para a recuperação dos investimentos privados. A mudança de ênfase na política se refletiu na atividade econômica a partir de 1968, quando o PIB cresceu 9,8\%, mais do que o dobro do resultado ano anterior. As exportações e importações cresceram vigorosamente no período de 1968 a 1973. Os bens manufaturados lideraram o crescimento das exportações e alcançaram um incremento de $639 \%$. A primeira década do regime militar seguiu, dessa forma, o caminho de tentar melhorar as contas externas, através do aumento das exportações e da substituição das importações. O milagre do período foi a combinação de crescimento econômico com a redução do ritmo da inflação e com a transformação dos déficits do balanço de pagamentos em superávits (HERMANN, 2011, p. 64-70).

O período de 1974 a 1984 marcou o auge e também o esgotamento do modelo de crescimento econômico iniciado nos anos 1950, calçado na industrialização por substituição de importações comandada pelo Estado através de investimentos e créditos públicos, e no endividamento externo. Essa fase da história compreende os governos do general Ernesto Geisel, do general João Figueiredo e do primeiro presidente civil depois do golpe, José Sarney (HERMANN, 2011, p. 73-95). Foi também durante esse período que aconteceram as duas 
crises do petróleo. No primeiro, em 1974, a importação de combustíveis representou $23 \%$ da despesa com importações e ameaçou o equilíbrio externo. O governo Geisel optou então por aproveitar a liquidez externa para financiar os ambiciosos programas de investimento estatal. Com a disponibilidade de recursos nos bancos internacionais, as taxas de juros reais estavam negativas.

O II Plano Nacional de Desenvolvimento (II PND) priorizou o setor energético, siderúrgico, petroquímico, de bens de capital e infraestrutura de transportes. Foi construída a hidrelétrica de Itaipu, a maior do mundo até então. Anos à frente, no final da década de 1970, o custo dos financiamentos se revelou muito superior às estimativas iniciais por causa da disparada dos juros internacionais. A estratégia de ampliar o papel de um Estado empresário, às custas de endividamento externo, acabou por levar o Brasil para a crise da dívida (CARDOSO, 2013, p.187-208). O segundo choque do petróleo, em 1979, causou uma nova desaceleração da economia mundial e limitou a margem de manobra das políticas econômicas, no governo de Figueiredo (CAMARGO, 2010, p. 217). Nem a volta de Delfim Neto para a área econômica, desta vez para o ministério do Planejamento, impediu que o Brasil tivesse que recorrer a um empréstimo do Fundo Monetário Internacional (PIRES, 2010, p. 235-236). O forte aumento da inflação e a deterioração das contas públicas e externas eram um sinal da exaustão do II PND. As dificuldades características dos anos de 1981 a 1983 inauguraram um longo período de estagnação da economia que se estendeu até 1990 (HERMANN, 2011, p. 73 95).

Embora tenha permitido a construção de um parque industrial moderno, o modelo de desenvolvimentista por substituição de importações deixou como herança a inflação alta e os efeitos de uma política protecionista prolongada. Para Pinheiro (2013), como o mercado doméstico se manteve isolado da competição internacional durante muitos anos, o país não conseguiu alcançar competitividade internacional em boa parte dos setores comtemplados pela política industrial. Isso acontece porque setores extremamente protegidos tendem a se desenvolver com tecnologia defasada, incapaz de garantir competividade no mercado internacional no longo prazo. Nesse sentido, a experiência industrial brasileira se diferenciou do que fizeram Japão, Coreia do Sul e China, onde foram implementados diversos incentivos para ganhos de produtividade. Na Coreia do Sul, as empresas foram expostas a mecanismos que combinavam incentivos a exportações e punições, como a perda dos benefícios, em caso de as metas não serem alcançadas. Na China, a competividade entre as diferentes regiões 
motivou o incremento de eficiência e também foram impostas metas de vendas para o exterior (PINHEIRO, 2013, p. 397-399).

No Brasil, por outro lado, o Estado, que subsidiava a expansão da indústria e a protegia da concorrência externa, acabou por impedir que a grande parte das empresas conquistassem eficiência. Em contraste a outras iniciativas estatais, a Empresa Brasileira Aeronáutica, a Embraer, instituída em 1969, revelou-se um raro exemplo bem-sucedido de iniciativa industrial promovida pelo governo. A Embraer, desde sua fundação, descumpriu metas de nacionalização de componentes e não se acomodou em vender seus aviões para o mercado doméstico protegido (CARDOSO, 2013, p. 184-187). A Embraer é hoje uma das maiores empresas exportadoras do Brasil e seus jatos protagonizam importantes saldos para a exportação de bens manufaturados e de alta tecnologia.

A despeito das críticas feitas às distorções causadas pela proteção da indústria nacional, entre os anos de 1950 e 1980, o país passou por uma enorme transformação. A economia cresceu a taxas bastante elevadas, se comparadas com o resultado mundial, e deixou de ser predominantemente agrícola para tornar sua produção concentrada na indústria e no setor de serviços. E, apesar de todos os problemas, o modelo desenvolvimentista resultou em uma mudança de padrão histórico no comércio exterior brasileiro. A balança comercial, antes concentrada em produtos básicos, passou a mostrar um crescimento da participação dos manufaturados como consequência do engajamento brasileiro na busca pela industrialização e modernização do setor produtivo. A partir de 1970, o percentual de produtos primários caiu de forma significativa e houve um aumento extraordinário das exportações de produtos semimanufaturados e manufaturados.

A participação dos manufaturados no valor total das exportações deu saltos entre 1960 e 1980. A modernização da estrutura industrial brasileira, característica da era desenvolvimentista, resultou na diversificação da estrutura produtiva e no aumento de produtividade da economia. Assim, o Brasil assistiu a um considerável crescimento da competitividade internacional naquele momento. Em 1979, pela primeira vez na história, os manufaturados corresponderam a uma parcela maior no total das exportações do país. Além disso, o saldo da balança comercial brasileira foi positivo de 1981 e até 1994. O resultado da subtração das importações e exportações voltou a fechar no negativo entre 1995 e o ano 2000 (GONÇALVES, 2013, p. 33-53). 
Tabela 1: Exportações Brasileiras por tipo de produto (1940-1999)

\begin{tabular}{|l|c|c|c|}
\hline & Básicos & Semimanufaturados & Manufaturados \\
\hline $1940-1949$ & $77,8 \%$ & $12,5 \%$ & $9,7 \%$ \\
\hline $1950-1959$ & $90,5 \%$ & $8,4 \%$ & $1,1 \%$ \\
\hline $1960-1969$ & $81,9 \%$ & $10,6 \%$ & $7,2 \%$ \\
\hline $1970-1979$ & $59,8 \%$ & $9,9 \%$ & $28,0 \%$ \\
\hline $1980-1989$ & $34,5 \%$ & $11,2 \%$ & $53,2 \%$ \\
\hline $1990-1999$ & $25,6 \%$ & $16,3 \%$ & $56,6 \%$ \\
\hline
\end{tabular}

Fonte: Gonçalves (2013, p.44)

Nota: o somatório não é igual a 100 devido às Operações Especiais.

A partir dos anos 1980, o país entrou em uma trajetória de forte desestabilização macroeconômica, quando fracassaram sucessivos planos econômicos que tentavam solucionar o problema e combater a inflação. O governo José Sarney naufragou em todas as tentativas de enfrentar a crise cambial e o danoso processo inflacionário. Ele também saiu derrotado dos esforços de renegociação da dívida externa. Diante da disparada da inflação e da asfixia cambial, Sarney decretou a moratória da dívida, o que comprometeu a credibilidade internacional do Brasil por mais de uma década (CARDOSO, 2013, p. 193). A atuação do sucessor, o primeiro presidente eleito democraticamente depois do golpe de 1964, Fernando Collor de Mello, também terminou em fiasco.

O sequestro de ativos financeiros e o congelamento da poupança do Plano Collor I provocaram uma queda do produto interno bruto (PIB) de 4,3\% (CARDOSO, 2013, p. 194). Ademais, Collor adotou as premissas defendidas pelas organizações multilaterais, entre elas o FMI, com a receita inventada pelo Consenso de Washington. Para Bresser Pereira (1991), a expressão 'consenso' talvez fosse forte demais para definir uma espécie de propostas comuns que existiam em Washington e nos países desenvolvidos que diziam respeito à natureza da crise latino-americana e às reformas necessárias para superá-la. Entre as linhas gerais defendidas pelo Consenso de Washington, estavam liberalização financeira, abertura comercial, supressão de restrições ao investimento estrangeiro direto, privatizações e reforma cambial. O receituário liberal foi contemplado pelo Plano Collor I que confiscou e congelou $80 \%$ dos depósitos em conta corrente e poupança, acabou também com subsídios e incentivos fiscais, liberalizou o câmbio, abriu o mercado brasileiro de forma abrupta e iniciou a privatização de empresas estatais (PIRES, 2010, p. 262-269). A despeito da ineficácia do plano para debelar a inflação, a partir de 1991, as reformas implementadas por Collor resultaram em uma acelerada 
acumulação de reservas internacionais que serviriam de suporte fundamental para o que viria a seguir, o Plano Real (CARDOSO, 2013, p. 185).

Com a queda do presidente Collor, que sofreu um processo de impeachment e depois renunciou por causa de denúncias de corrupção, Itamar Franco assume o poder e, meses depois, lançou o Plano Real, com o ministro Fernando Henrique Cardoso à frente da Fazenda. O Real, implementado a partir de junho de 1993, representou uma inovação da política macroeconômica para a história brasileira. O Plano adotou a taxa de câmbio e a poupança externa como instrumentos-chave da estabilização. A abertura comercial e financeira ao exterior estava suficientemente avançada para viabilizar o uso de uma âncora cambial na disciplina dos preços e o ingresso de capital externo servia para financiar o déficit público.

Em janeiro de 1999, durante o governo de Fernando Henrique Cardoso, uma grave crise na Rússia deixou investidores receosos com os mercados emergentes e uma brusca fuga de dólares do Brasil obrigou o Banco Central a mudar o regime cambial de fixo para flutuante. Foi também necessária uma série de mudanças para manter o Real e ajustar a trajetória da economia para recuperar a capacidade de financiamento externo e do governo. A segunda fase do Plano Real implicava basicamente em três grandes alterações de política econômica: o abandono da âncora cambial para a adoção do câmbio flutuante, a criação de metas de inflação e o planejamento de um programa de ajuste fiscal para tentar reverter o déficit e a dívida pública interna (SILBER, 2010, p. 30-35).

Para Gonçalves (2013, p. 54), a política macroeconômica criou um tridente satânico que consistia em manter os juros altos para o controle da inflação e para atrair recursos destinados ao financiamento da dívida pública, além de uma penosa política de superávit primário e do câmbio flutuante. A receita dominou o segundo governo FHC e todo o governo de Luiz Inácio Lula da Silva. De 1995 em diante, o processo de liberalização econômica foi um elemento estrutural deste novo modelo e avançou significativamente, em velocidade, extensão e profundidade. A inserção do Brasil no processo de globalização se deu de forma passiva, sem nenhum ganho de contrapartida. Diante da expansão dos fluxos internacionais de bens, serviços e capital, o país liberalizou e desregulamentou a economia nas esferas comercial, produtiva, tecnológica, monetária e financeira. O resultado foi o aumento da vulnerabilidade externa do país, isto é, na diminuição da capacidade de resistência a choques externos. As políticas, portanto, iniciadas em 1990, e aprofundadas em 1995, marcaram definitivamente a ruptura do modelo desenvolvimentista para a implementação de um modelo de desenvolvimento liberal periférico (GONÇALVES, 2013, p. 53-37). 
Sem um projeto de desenvolvimento, o governo Cardoso ficou marcado pela estagnação da economia e pela interrupção de um ciclo de sessenta anos de desenvolvimento caracterizado por altas taxas de crescimento. O choque de abertura, por outro lado, tirou a comodidade de empresários brasileiros que andavam sob o abrigo de um protecionismo exacerbado. Apesar de crítico tenaz do paradigma neoliberal, Cervo (2008) reconhece que a competição com o mercado externo contribuiu para elevar a produtividade sistêmica da economia brasileira, tanto da indústria, quanto da agricultura e dos serviços (CERVO, 2008a, p. 81). A combinação da abertura com a privatização de empresas prestadoras de serviços públicos representou uma mudança radical do modelo de economia protegida vigente e obrigou o setor privado a se modernizar para enfrentar o novo ambiente de negócios. Para o comércio exterior, a mudança foi percebida no longo prazo. A percepção de que a situação externa do Brasil estava mudando de forma estrutural só se deu no final de 2002, quando o país alcançou um superávit comercial de US\$ 13 bilhões (GIAMBIAGI, 2011, p. 167). O saldo comercial, que entre 1995 e 2000 ficou no vermelho como resultado da abertura da economia e da exposição do mercado brasileiro à concorrência externa, voltou a fechar no positivo ainda em 2001. O superávit da balança perdurou pelos onze anos seguintes e só foi interrompido no último ano do primeiro mandato da presidenta Dilma Rousseff, em 2014.

Gráfico 2: Evolução do Comércio Exterior do Brasil a partir de 1989

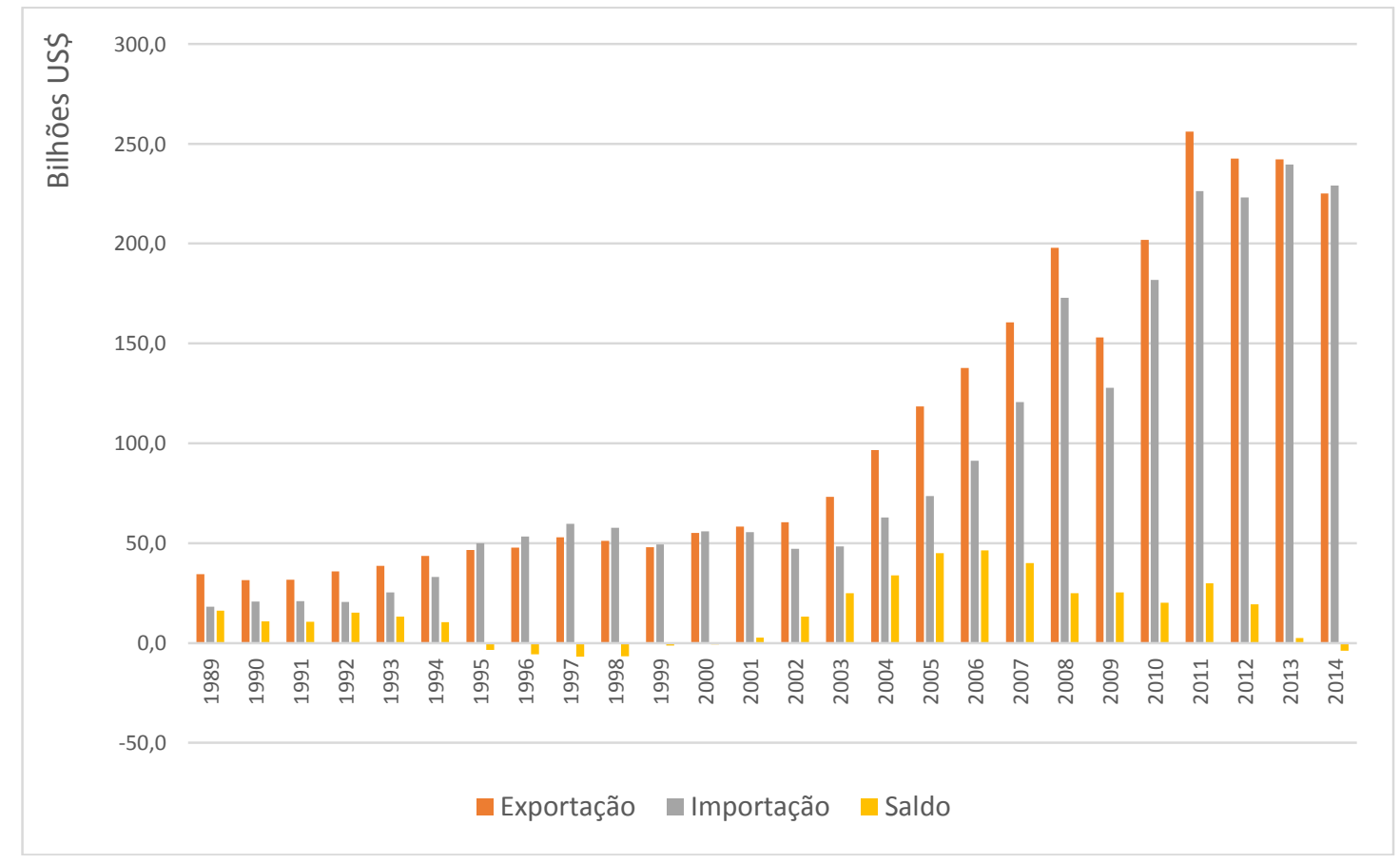

Fonte: Elaboração própria a partir de dados do Aliceweb (BRASIL, 2014a). 
Os superávits comerciais foram significativamente altos na primeira década dos anos 2000. Em 2006, o Brasil registrou o melhor resultado, com um saldo de US\$ 46,5 bilhões. Para Fonseca e Marconini (2006), a conjuntura do comércio a partir de 2001 foi, em grande medida, fruto de condições mundiais positivas, particularmente pelo preço alto das commodities e pelo ingresso da China no mercado internacional. A pujança do comércio e das exportações se deve também em grande medida ao processo de abertura, modernização e reestruturação pelo qual passou o setor produtivo nos anos 1990 (FONSECA; MARCONINI, 2006, p. 6). A partir de 2007, as importações passaram a crescer em percentuais acima das exportações, como reflexo da valorização do real; e assim, os superávits comerciais começaram a diminuir gradativamente (ASSOCIAÇÃO DE COMÉRCIO EXTERIOR DO BRASIL, 2012).

Durante os anos do governo do presidente Lula, a tendência de maior participação de manufaturados no comércio exterior brasileiro se inverteu. A média de manufaturados na balança comercial, que alcançava 56,8\% em 2002, sofreu sucessivas reduções e fechou o ano de 2010 em 45,6\%. A queda na comercialização dos produtos com valor agregado no exterior se refletiu na queda do desempenho da indústria nacional. O peso da indústria de transformação no PIB caiu de 18\%, em 2002, para 16\% em 2010. O crescimento da indústria de transformação ficou abaixo da média de evolução do PIB, que cresceu a uma taxa anual média de $4 \%$, e fícou atrás do crescimento registrado pelos setores de mineração e de agropecuária. Entre 2002 e 2010, a taxa de crescimento real do valor adicionado da indústria de transformação atingiu 2,7\%, enquanto o da mineração ficou em 5,5\% e o da agropecuária em 3,2\% (GONÇALVES, 2013, p.91).

A mudança do perfil da balança comercial na gestão Lula foi uma quebra preocupante no padrão de comércio construído durante a era desenvolvimentista. Para Gonçalves (2013), o Brasil, que antes indicava uma menor dependência em relação às exportações de commodities, sofreu uma alteração de tendência durante o governo do Partido dos Trabalhadores. A alteração do perfil da balança comercial, além da desindustrialização, dessubstituição de importações e reprimarização, também significou um processo de maior dependência tecnológica ao país, que perdeu competitividade internacional (GONÇALVES, 2013, p. 92-109). 
Gráfico 3: Exportações brasileiras por fator agregado (1989-2014)

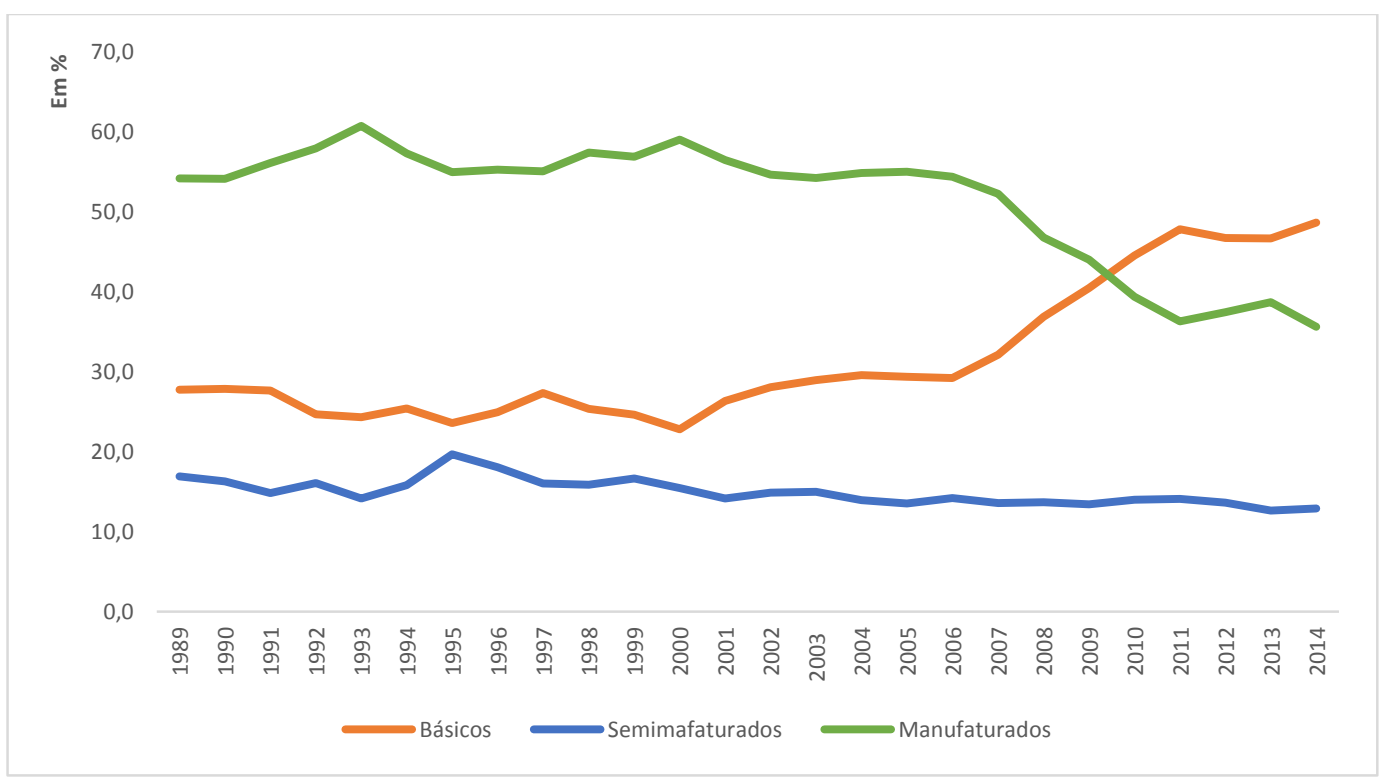

Fonte: Elaboração própria a partir de dados do Aliceweb (BRASIL, 2014a)

O comércio brasileiro com a África também experimentou o mesmo fenômeno de piora do perfil de produtos exportados. Entre os dois lados do oceano Atlântico, houve um significativo crescimento da corrente de comércio, sem, no entanto, implicar em um aumento na venda de produtos de alta tecnologia. O fluxo de comércio entre o Brasil e a África nos anos Lula caracterizou-se fundamentalmente pelas trocas de commodities, produtos básicos como açúcar, cereais e petróleo (MAIA, 2013). O padrão de comércio entre os dois mercados passou a concentrar-se, portanto, na negociação de produtos majoritariamente primários, sem valor sendo agregado pelas cadeias produtivas. Uma média de $85 \%$ das importações brasileiras para a África se refere a petróleo; enquanto mais de 50\% das importações da África consistem em alimentos: açúcar, carne e cereais (VIEIRA, 2011).

O retrato do comércio exterior com os países da África mostra que o Brasil perdeu espaço no segmento de mercado de industrializados. A importação total de mercadorias industrializadas feita pelos países africanos do mercado mundial cresceu acentuadamente ano após ano. Antigos parceiros comerciais do Brasil na África, no entanto, têm preferido comprar de fornecedores na China e na União Europeia por uma série de fatores que prejudicam a competitividade dos produtos brasileiros; entre essas questões está a falta de linhas de crédito para financiar as exportações do Brasil e, segundo o pesquisador Altair Maia, outro fator poderia ser a deficiência do transporte marítimo entre os dois pontos (MAIA, 2013, p. 32).

Maia afirma que, apesar de a África estar a apenas um oceano de distância, e de africanos e brasileiros terem suas costas uma de frente para a outra, a viagem de um contêiner poderia 
custar o dobro do valor no transporte para China, Europa, Japão e Estados Unidos, que estão muito mais distantes do Brasil. Isso acontece porque, segundo o autor, não existiriam rotas regulares de navios e os produtos exportados teriam que viajar muitas vezes até a Europa, onde precisariam de um transbordo, para só depois seguirem até a África (MAIA, 2013).

Um levantamento feito com as operadoras de transporte marítimo que atuam no Brasil, no entanto, mostrou um equívoco na afirmativa de Maia uma vez que existem rotas de navios que fazem entrega de produtos entre os dois continentes, sem que haja necessidade de transbordo em portos na Europa. As empresas Maersk Line, Nile Dutch e CMA CGM mantém rotas periódicas entre o Brasil e a África Ocidental. A Hamburg Süd opera um serviço direto para a África do Sul. A rota da Maersk Line faz o trajeto entre as cidades de Buenos Aires, Rio Grande, Itajaí, Santos, Rio de Janeiro, Lome, Pointe Noire e Luanda, com duas partidas mensais.

Figura 1: Rota de transporte marítimo operada pela Maersk Line

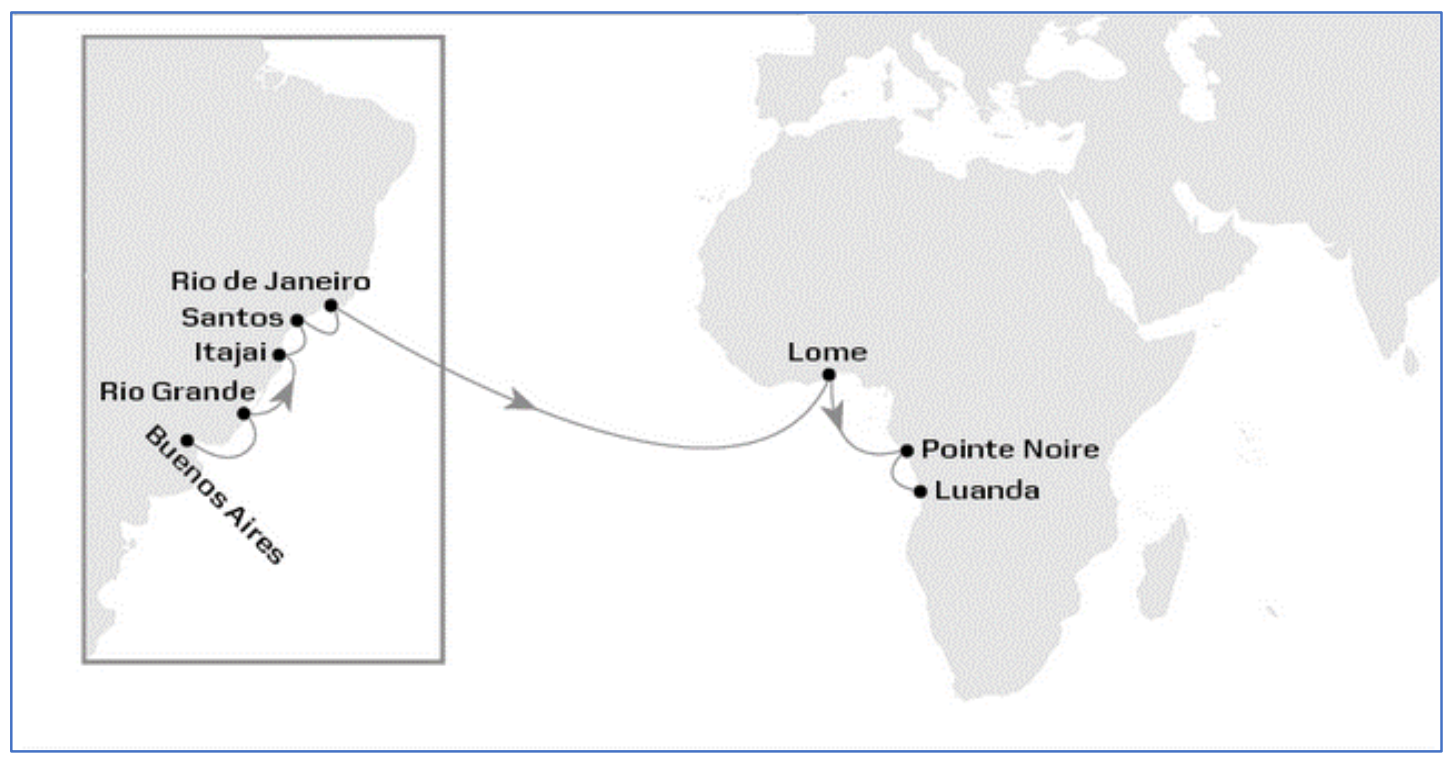

Fonte: Maersk Line, 2014

A Nile Dutch também oferece o transporte direto entre as cidades brasileiras e africanas, sem parada para troca de navio ou transbordo. A rota entre os dois continentes se dá entre as cidades do Rio de Janeiro e de Pointe Noire. O serviço existe há mais de uma década. Segundo a companhia, a rota tornou-se um marco simbólico da expansão econômica dos dois lados do Oceano Atlântico. 
Figura 2: Rota de transporte marítimo operada pela Nile Dutch

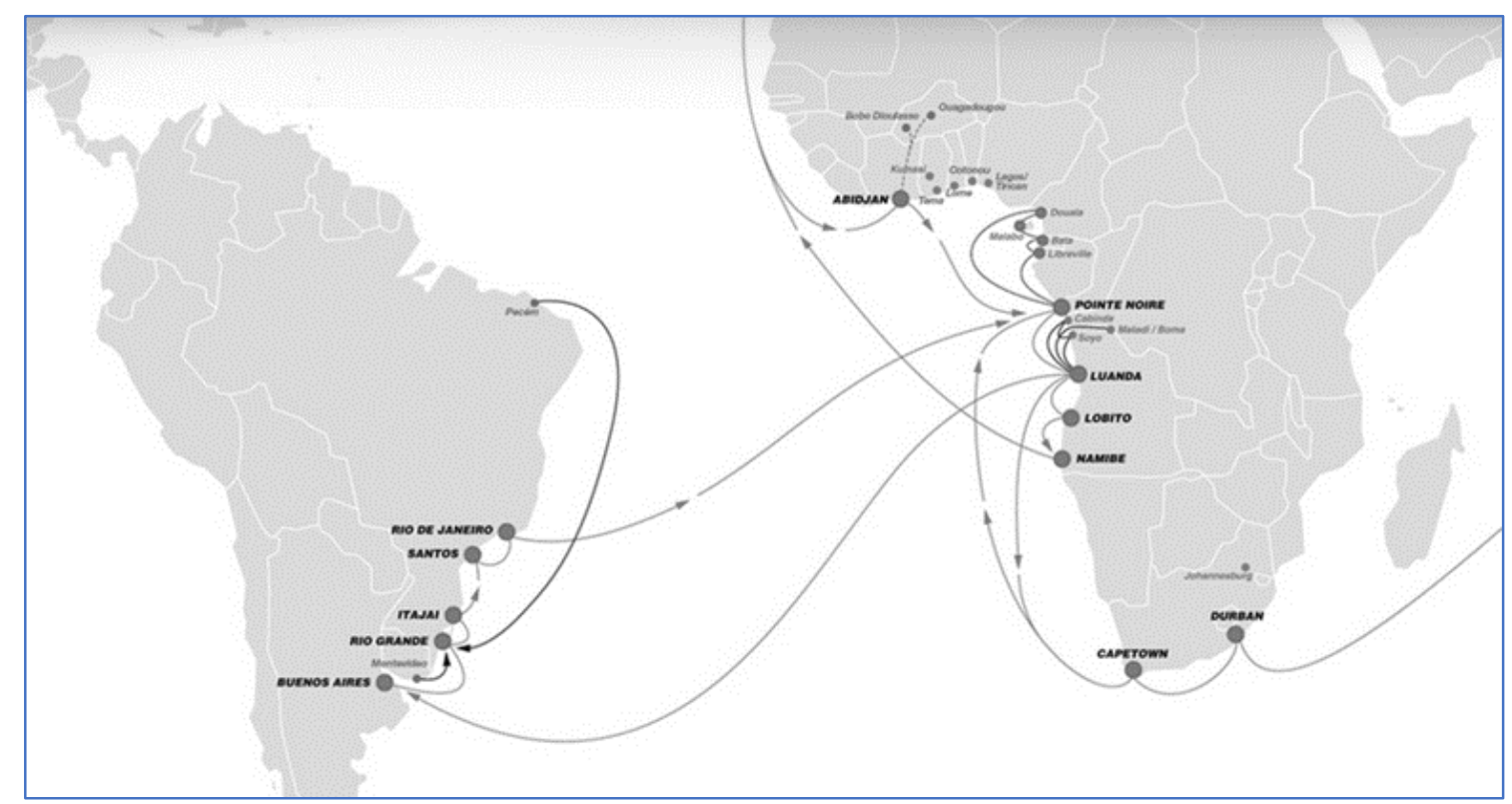

Fonte: Nile Dutch, 2014

Além da Maersk e da Nile Dutch, a CMA-CGM opera o trecho entre Santos-AbidjanTema-Pointe Noire-Luanda, também com frequência quinzenal.

Figura 3: Rota de transporte marítimo operada pela CMA CGM

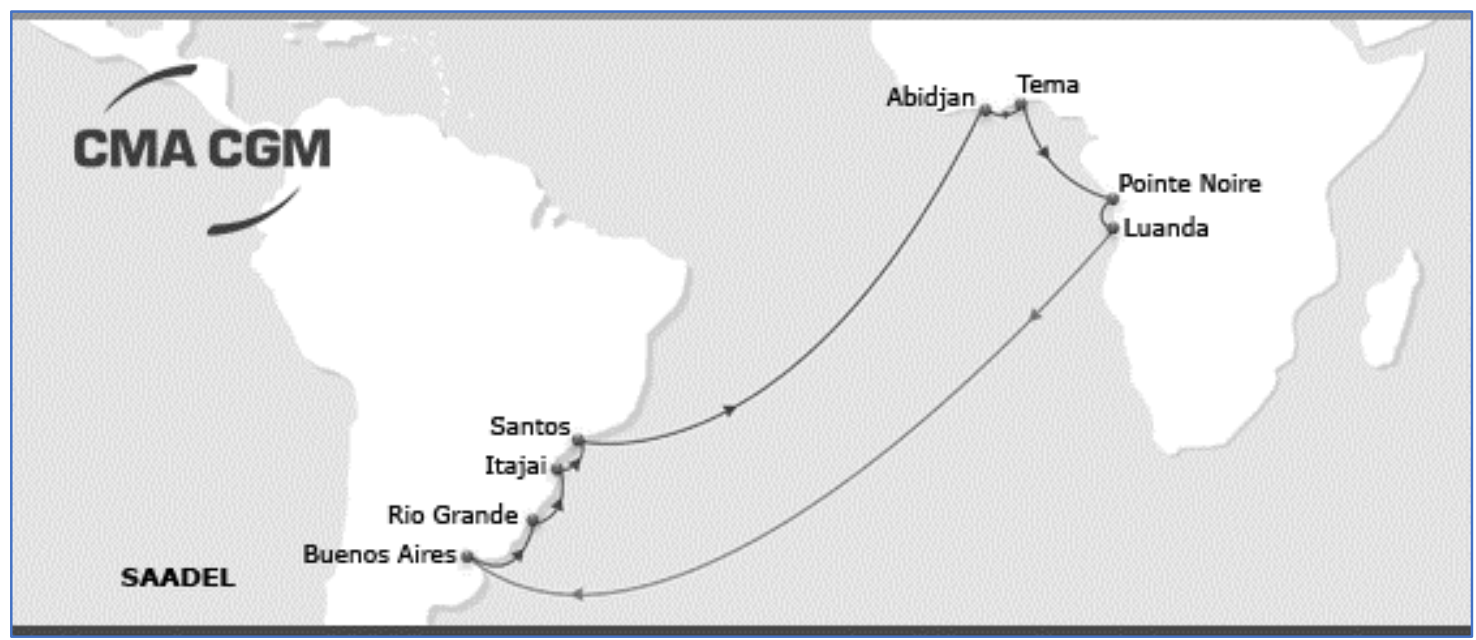

Fonte: CMA CGM, 2014

Outra empresa, a Hamburg Süd oferece um serviço direto entre o Brasil e a África, com saída dos portos de Rio Grande, Itapoá, Navegantes, Paranaguá e Santos com descarga no porto 
de Ngqura, na África do Sul. A empresa não tem serviço para a África com transbordo na Europa.

Figura 4: Rota de transporte marítimo operada pela Hamburg Süd

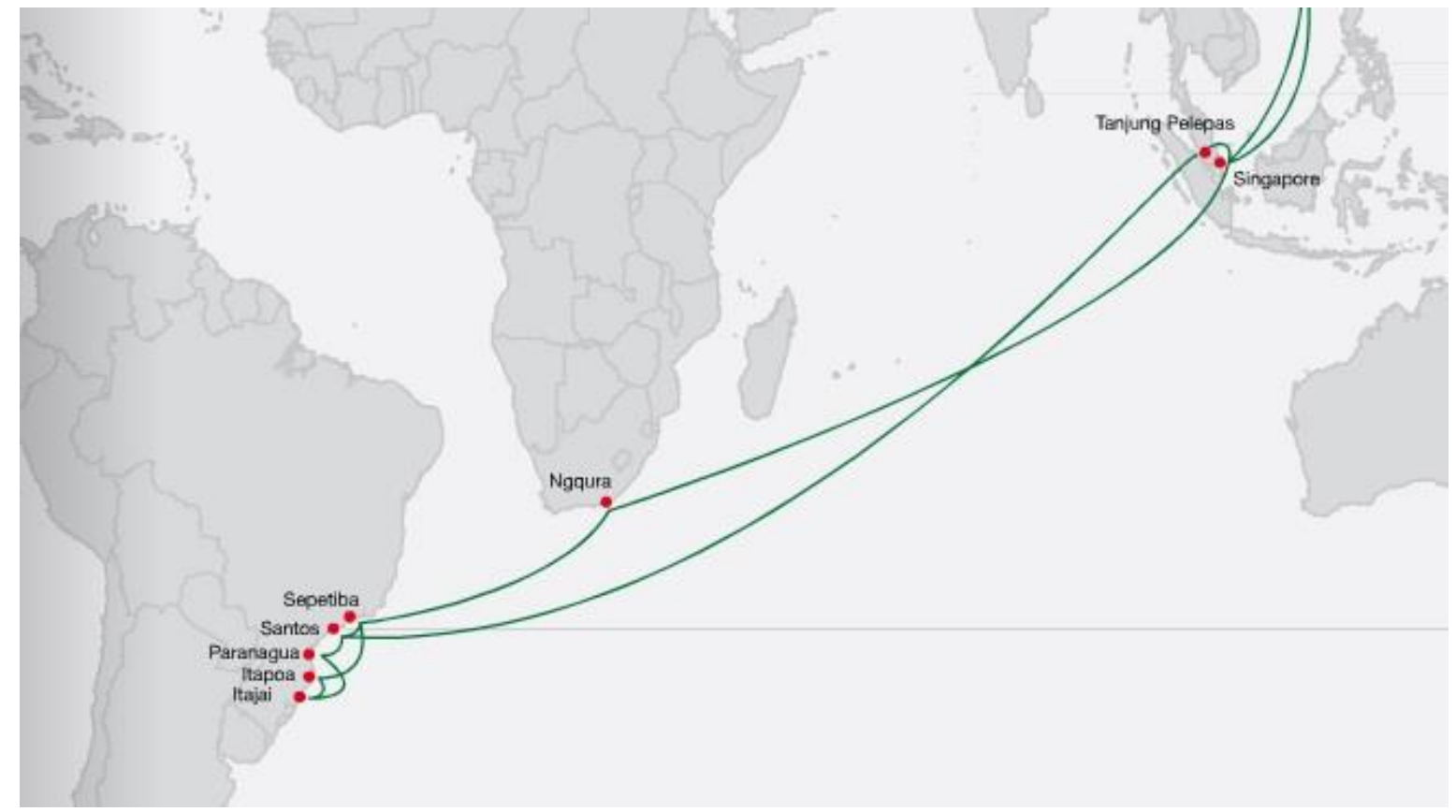

Fonte: Hamburg Süd, 2015

Historicamente os países desenvolvidos são os principais parceiros comerciais do Brasil. A participação da África nas exportações brasileiras esteve quase sempre próxima dos 4\%, desde a década de 1970. No final do governo de Cardoso, o percentual fechou em 3,91\%. Ao final do governo Lula, o índice subiu e terminou em 4,59\%. A trajetória desse comércio ao longo dos governos dos dois mandatários será tema de estudo mais detalhado nos capítulos a seguir. Neste momento, o principal parceiro comercial do Brasil é a China, que ultrapassou a posição antes ocupada pelos Estados Unidos. Na observação dos blocos econômicos, a Ásia é atualmente o principal destino das exportações brasileiras. 
Tabela 2: Principais destinos das exportações do Brasil em 2014

\begin{tabular}{|l|c|c|}
\hline & Valor (US\$ milhões) & Participação (\%) \\
\hline Ásia & 73.513 & 32,7 \\
\hline América Latina e Caribe & 46.045 & 20,5 \\
- Mercosul & 25.054 & 11,1 \\
\hline União Europeia & 42.047 & 18,7 \\
\hline Estados Unidos & 27.144 & 12,1 \\
\hline Oriente Médio & 10.419 & 4,6 \\
\hline África & 9,701 & 4,3 \\
\hline Europa Ocidental & 4.583 & 2,0 \\
\hline
\end{tabular}

Fonte: BRASIL, 2015

Nenhum país africano aparece entre os dez principais compradores de mercadorias brasileiras. Nessa lista, estavam, em 2014, China, Estados Unidos, Argentina, Países Baixos, Japão, Alemanha, Chile, Índia, Venezuela e Itália. Entre os principais fornecedores do Brasil, a Nigéria ocupa o quinto lugar.

Tabela 3: Principais países fornecedores do Brasil em 2014

\begin{tabular}{|l|c|c|}
\hline & Valor (US\$ milhões) & Participação (\%) \\
\hline China & 37.341 & 16,3 \\
\hline Estados Unidos & 34.999 & 15,3 \\
\hline Argentina & 14.143 & 6,2 \\
\hline Alemanha & 13.837 & 6,0 \\
\hline Nigéria & 9.495 & 4,1 \\
\hline Coreia do Sul & 8.526 & 3,7 \\
\hline Índia & 6.635 & 2,9 \\
\hline Itália & 6.310 & 2,8 \\
\hline Japão & 5.902 & 2,6 \\
\hline França & 5.698 & 2,5 \\
\hline
\end{tabular}

Fonte: BRASIL, 2015

Considerado o mercado fornecedor em blocos comerciais, a África ficou atrás de Ásia, União Europeia, América Latina e Estados Unidos, em 2014, como principal local de compras feitas pelo Brasil lá fora. De tudo o que o país importou nesse ano, 7,4\% vieram do continente africano. Os próximos capítulos apresentarão o perfil e os principais produtos dessa balança comercial. 
Tabela 4: Principais mercados fornecedores do Brasil em 2014

\begin{tabular}{|l|c|c|}
\hline & Valor (US\$ milhões) & Participação (\%) \\
\hline Ásia & 71.168 & 31,1 \\
\hline União Europeia & 46.713 & 20,4 \\
\hline América Latina e Caribe & 37.578 & 16,4 \\
- Mercosul & 18.446 & 8,1 \\
\hline Estados Unidos & 35.299 & 15,4 \\
\hline África & 17.061 & 7,4 \\
\hline Oriente Médio & 7.999 & 3,5 \\
\hline Europa Ocidental & 3.961 & 1,7 \\
\hline
\end{tabular}

Fonte: BRASIL, 2015

Os capítulos adiante mostrarão a trajetória do comércio com a África, o detalhamento das trocas de produtos e o perfil das importações e exportações. A pesquisa detalhará ainda a posição da África no comércio exterior brasileiro no governo FHC e Lula. O estudo revelará também como eram as relações internacionais do Brasil com o continente africano nos anos Cardoso e Lula e como isso se refletiu na balança comercial. Finalmente, o exame tentará avaliar se as relações internacionais do Brasil mais intensas com a África, durante o governo Lula, resultaram em aumento e melhora do comércio entre os dois mercados. 


\section{O COMÉRCIO EXTERIOR DO BRASIL COM A ÁFRICA NO GOVERNO FERNANDO HENRIQUE CARDOSO (1995-2002)}

Os anos de governo de Fernando Henrique Cardoso caracterizaram-se por pequenas oscilações na corrente de comércio entre o Brasil e a África. Nas relações com o continente, FHC abandonou relativamente a tradicional política africana construída pelo Brasil durante décadas. Entre as causas do afastamento, segundo análise de Saraiva (2002), estavam os constrangimentos gerados pela adoção do modelo liberal de desenvolvimento. O distanciamento seria resultado também do encantamento de formuladores da política exterior brasileira pelos polos do poder global que, com isso, distanciaram-se de uma das matrizes que confere identidade à inserção do Brasil no mundo: a relevância estratégica, cultural, econômica e identitária do continente africano (SARAIVA, 2002, p.5-9).

Ao longo do governo de Fernando Henrique, a diplomacia brasileira comprometeu-se com a modelagem de uma nova inserção internacional, particularmente orientada por uma maior aproximação econômica e comercial com os países desenvolvidos, tidos como os únicos capazes de garantir ao Brasil o ingresso no eixo dinâmico da economia globalizada (RIBEIRO, 2010, p. 63). As relações internacionais com Estados Unidos e Europa atingiram níveis qualitativos excepcionais no governo FHC. Ao mesmo tempo, enquanto se avançou em direção ao aprimoramento das relações com a Ásia, o sucesso do Mercosul fez as atenções do empresariado convergirem para os vizinhos continentais. Foi esse contexto que o continente africano presenciou durante os anos de Cardoso na presidência, uma realidade que fez com que a posição relativa da África perdesse atrativos (PIMENTEL, 2000, p. 8).

O declínio do contato do Brasil com a África foi uma característica dos anos pós-Guerra Fria, principalmente no âmbito das relações comerciais. Apesar disso, a política externa brasileira fez opções seletivas. Não foi a morte da política para a África, mas o Brasil fez opções menos continentais para se concentrar na região austral do continente (RIZZI, 2008, p. 295296).

A situação política do continente do outro lado do Atlântico é outra razão que justifica o estado sereno do relacionamento. Houve um certo retraimento da presença brasileira no continente africano, motivado principalmente, pela profunda crise que atingiu boa parte daqueles países e pelas prioridades dadas pela diplomacia naquele momento. Entre essas questões, estavam a política de abertura comercial implementada no Brasil e o direcionamento à regionalização do país, o que resultou na ênfase dada ao Mercosul. Para Penna Filho (2013, 
p. 10-11), é incorreto dizer que o Brasil tenha abandonado a África nos anos 1990. África do Sul, Nigéria e Angola, ao lado dos demais membros africanos da Comunidade dos Países de Língua Portuguesa (CPLP), continuaram figurando como parceiros ativos do Brasil (PENNA FILHO, 2013, p.10-11).

O presidente Fernando Henrique incorporou a proposta de criação da CPLP, herdada de seus antecessores Itamar Franco e José Sarney. Desde a década de 1980, acumularam-se sinais de um interesse na institucionalização dos lusófonos; quando observou-se uma ênfase nos temas específicos da língua portuguesa, como a discussão sobre um acordo ortográfico. Em 1989, o ministro da Cultura, José Aparecido de Oliveira passou a liderar a empreitada até o final da presidência de Itamar Franco, quando torna-se Embaixador do Brasil em Portugal para se dedicar à missão de concretizar a Comunidade. Apesar de um certo mal-estar transitório, quando os primeiros protagonistas do projeto deixaram o processo, o Itamaraty e o governo FHC deram continuidade à formação da CPLP, que se consolidou em 1996 (SARAIVA, 2001, p. 23-27).

A formação da CPLP era, no entanto, pouco significativa diante do silêncio diplomático que se estendia pelo continente. Para Saraiva (2002), basta ver a evolução do quadro de diplomatas brasileiros no exterior para aferir a diminuição gradativa da importância estratégica da África para o Brasil. A África esteve na contramão da tendência de ampliação do número de diplomatas acreditados junto aos demais Estados amigos. As três dezenas de diplomatas profissionais que atuavam naquele continente, nas diferentes missões diplomáticas no início da década de 1980, foram reduzidas em cerca da metade. Diplomatas brasileiros foram deslocados da África para outros continentes e áreas de maior prioridade, como a Europa, a América do Sul e os Estados Unidos (SARAIVA, 2002, p. 9-10).

A debilidade do crescimento econômico, característica daqueles anos, se tornou um impeditivo às pretensões diplomáticas do país, com impacto direto sobre as relações com o continente africano, acredita Ribeiro (2007). O Ministério de Relações Exteriores, argumentam membros do corpo diplomático, viu-se obrigado, por restrições orçamentárias, a determinar o fechamento dos postos diplomáticos em Adis Abeba (Etiópia), Dar es Salam (Tanzânia), Iaundê (Camarões), Kinshasa (República Democrática do Congo), Lomé (Togo) e Lusaca (Zâmbia). A redução da presença da diplomacia brasileira acabou por limitar a capacidade da política externa em alavancar objetivos estratégicos de caráter político e econômico na África. A vertente atlântica deixou de representar uma dimensão de relevância para a política externa 
brasileira e o continente africano não foi uma região privilegiada nos anos FHC (RIBEIRO, 2007, p. 129-162).

Tabela 5: Viagens do presidente Fernando Henrique Cardoso à África

\begin{tabular}{|c|l|}
\hline \multicolumn{1}{|c|}{ Data } & Evento \\
\hline 24 a 28.11.1996 & Visitas oficiais às Repúblicas de Angola e da África do Sul \\
\hline 16 a 18.07.2000 & $\begin{array}{l}\text { Participação na III Conferência de Chefes de Estado e de Governo da } \\
\text { Comunidade dos Países de Língua Portuguesa - CPLP, na cidade de } \\
\text { Maputo, República de Moçambique }\end{array}$ \\
\hline 31.08 a 04.09.2002 & $\begin{array}{l}\text { Participação na Cúpula Mundial sobre Desenvolvimento Sustentável em } \\
\text { Johanesburgo, República da África do Sul }\end{array}$ \\
\hline
\end{tabular}

Fonte: Biblioteca da Presidência da República (2015).

A diplomacia presidencial de FHC na África foi também pouco presente. Cardoso visitou o continente africano em apenas três oportunidades. Contudo, foi Fernando Henrique que selou, com uma visita oficial, a reaproximação do Brasil com a África do Sul, depois do fim do regime do apartheid. A política oficial de segregação racial era um contraponto à sociedade brasileira, que sustentava o discurso oficial, falacioso, é verdade, de ter construído uma democracia racial, com convívio harmônico entre as raças. No final dos anos 1970, a África do Sul estava alinhada quase que somente com Estados isolados da comunidade internacional, com os quais tinha em comum acusações de desrespeito aos direitos humanos.

A política do apartheid não era o único argumento a afastar Brasil e África do Sul. Quase instantaneamente em que o governo angolano do Movimento Popular de Libertação de Angola (MPLA) era reconhecido pelo Brasil, o governo sul-africano patrocinava a invasão de Angola com tropas e prosseguia com o apoio às atividades de outro grupo nacionalista que lutava pelo poder, a União para Independência Total de Angola (UNITA). A agressão à Angola contribuiu ainda mais para que a relação entre os dois países se deteriorasse. O Brasil decidiu então se afastar da África do Sul e desestimular também o comércio exterior que tinha ganhado vigor especialmente durante a Segunda Guerra Mundial. O conflito desestabilizou temporariamente os fluxos tradicionais de comércio e, ainda que temporariamente, acabou por abrir novas rotas e permitir certa diversificação de parceiros. Com o término da guerra, houve uma tendência de declínio, mas o comércio permaneceu em um patamar mais elevado do que no período anterior ao conflito mundial (PENNA FILHO, 2008, p. 271) (PENNA FILHO, 2001, p. 69-88). 
Nos anos 1990, com o fim do apartheid e a eleição de Nelson Mandela, o Brasil acompanhou a retomada da aproximação com a África do Sul, em um comportamento semelhante ao adotado pela maior parte dos países do Ocidente. A partir desse momento, a África do Sul passou a ser considerada uma das prioridades da política externa no continente africano, vista como possível aliado no plano multilateral e parceira importante no plano do comércio bilateral. Do ponto de vista do país africano, no entanto, o Brasil estava longe de ser uma de suas prioridades no final da década de 1990. Antes da América Latina, interessavam à agenda externa da África do Sul: o continente africano, os Estados Unidos, a União Europeia e os países asiáticos, especialmente Japão e China. Deste lado do Atlântico, ainda durante a década de 1990, a África do Sul foi apontada pelo Itamaraty como um dos três países prioritários para a política externa brasileira no continente africano. Os outros dois eram Nigéria e Angola (PENNA FILHO, 2001, p. 69-88).

O governo Cardoso enviou para Angola o maior contingente militar brasileiro no exterior desde a II Guerra Mundial. O Brasil fez parte da Missão de Verificação de Paz das Nações Unidas em Angola (UNAVEM), sob a liderança da Organização das Nações Unidas (ONU), que compunha os esforços para promover a distensão da guerra civil que se instalara no país desde a independência em 1975 (GONÇALVES, MANDUCA, 2008). O governo FHC também se preocupou em emitir sinais de solidariedade ao continente africano. Nas proximidades de Luanda, foi instalado um Centro Móvel de Formação Profissional com capacidade para qualificar centenas de estudantes de nível médio por ano. A contrapartida do governo angolano era retribuir com regularidade o pagamento da dívida externa e olhar com simpatia os produtos e as empresas brasileiras (PIMENTEL, 2000, p. 13-14). Para o então ministro de relações exteriores Luiz Felipe Lampreia (1998), a participação do Brasil em forças de paz das Nações Unidas, particularmente em Angola e Moçambique, países africanos de expressão portuguesa, e o envolvimento nos esforços diplomáticos para superação do conflito interno na Guiné Bissau foram parte da expressão de uma maior capacidade e disposição do Brasil em atuar de forma mais ativa e abrangente na vida internacional e regional (LAMPREIA, 1998, p-14).

Apesar do argumento da presença brasileira na África, a percepção de um distanciamento do Brasil existia dentro do Itamaraty. A visita do presidente FHC à África do Sul e à Angola, em 1996, também tinha o intuito de reverter o decréscimo das relações com o continente. A chancelaria brasileira buscava abertamente empreender uma atualização dessas relações. Em artigo escrito para jornal Correio Braziliense, em 1996, Lampreia afirmou que era 
firme o compromisso do Brasil com as relações com a África e que o continente era um objetivo insubstituível da diplomacia brasileira. O intuito era a tentativa de construir uma política africana de resultados nos planos político, econômico e de cooperação (LAMPREIA, 1996, apud RIZZI, 2008, p. 301).

No final do governo FHC, as possibilidades na África começavam a ser percebidas. Em um texto publicado em maio de 2000, o embaixador José Vicente de Sá Pimentel descreve uma crescente mobilização em favor de um resgate da África na política externa. Para o autor, em tempos de paz e democracia no continente do outro lado do Atlântico, e em um ambiente de regras estáveis e previsíveis, a África potencializaria oportunidades, pela facilidade brasileira no diálogo com vários países africanos, pela capacidade técnico-científico-tecnológica em escala com as carências continentais e pela afinidade de experiências históricas. Nesse contexto, o Brasil poderia ser percebido pelos países africanos como um modelo, visto com simpatia pela maioria dos países da África Subsaariana, o que redundava, para Pimentel, em um considerável capital diplomático em debates e votações nos foros mundiais. Ainda segundo o autor, a solidariedade para com a África se apresentava como capaz de agregar valor e substância à política externa do Brasil (PIMENTEL, 2000, p. 22-23).

No meio do segundo mandato de FHC, a diplomacia coletiva do Mercosul concluiu um acordo com a África do Sul para formação de uma zona de livre comércio. O primeiro acordo assinado tinha a finalidade de fortalecer as relações existentes, promover o incremento do intercâmbio comercial e estabelecer as condições para a pretendida área de livre comércio. Foi o primeiro passo para ampliar as possibilidades de acordos para outros países do continente. Mais tarde, durante o governo de Luiz Inácio Lula da Silva, as negociações evoluíram para envolver a união aduaneira formada pela África do Sul, Namíbia, Botsuana, Lesoto e Suazilândia, a Southern African Customs Union (SACU). Um acordo de preferências tarifárias foi assinado em 2008-2009, mas, até 2014, não tinha entrado em vigor (BAUMANN, MACHADO, 2014, p. 95).

Para Baumann e Machado, o Brasil possui uma estratégia pouco ofensiva no que tange a acordos preferenciais de comércio. Esses acordos foram firmados com países de seu entorno e do restante da América Latina (via Aladi) ou com países em desenvolvimento em outras regiões do globo, como Ásia (Mercosul-Índia), África (Mercosul-Sacu e Mercosul-Egito) e Oriente Médio (Mercosul-Israel e Mercosul-Palestina). Contudo, apenas os assinados com Índia e Israel, em 2005 e 2007, respectivamente, estavam em vigor em 2014. Observa-se que o tempo médio para a entrada em vigência tem sido entre três e quatro anos (Ibidem). 
Um importante movimento político do governo FHC ao que se refere às relações com a África foi a renegociação de dívidas de países africanos com o Brasil, que tiveram pouco espaço de cobertura na imprensa. As primeiras negociações de débitos registradas no Sistema de Informações do Congresso Nacional (SICON) dão conta de que, nos anos de 1993 e 1994, ainda durante a presidência de Itamar Franco, a União pediu autorização ao Senado Federal para firmar contratos bilaterais de reescalonamento de dívida ou para contratar operações financeiras destinadas à negociação de débitos com três países: Guiné-Bissau, Mauritânia e Zâmbia (BRASIL, 2014b). Um levantamento feito pelo Senado Federal, apresentado no parecer do senador Ricardo Ferraço (PMDB/ES), mostrou que as concessões evoluíram da inicial remissão de juros de mora e dilatação de prazos originais de amortização à concessão parcial de perdão a valor devido.

Tabela 6: Número de resoluções referentes à renegociação de dívidas de países com o Brasil

\begin{tabular}{|l|l|}
\hline \multicolumn{1}{|c|}{ Governo } & \multicolumn{1}{c|}{ Número de resoluções apresentadas } \\
\hline $\begin{array}{l}\text { Fernando Henrique Cardoso } \\
(1995-2002)\end{array}$ & $\begin{array}{l}\text { 15 resoluções } \\
\text { (13 resoluções eram de países da África; 2 se referiam a Suriname) }\end{array}$ \\
\hline $\begin{array}{l}\text { Luiz Inácio Lula da Silva } \\
(2003-2010)\end{array}$ & $\begin{array}{l}\text { 5 resoluções } \\
\text { 3 resoluções eram de países da África; 1 se referia a Suriname; 1 dizia respeito a Bolívia) }\end{array}$ \\
\hline $\begin{array}{l}\text { Dilma Rousseff } \\
(2011-)\end{array}$ & $\begin{array}{l}\text { 9 resoluções } \\
\text { (todas as resoluções eram de países da África) }\end{array}$ \\
\hline
\end{tabular}

Fonte: BRASIL, 2013c.

Alguns países beneficiados com reestruturação, perdão ou reescalonamento de dívida nos anos de governo de Fernando Henrique Cardoso foram novamente alvo de renegociações nas gestões de Lula e Dilma Rousseff. Em todos os casos, os débitos se referem a vendas de mercadorias brasileiras para o continente africano. Alguns países foram alvo de mais de uma negociação ou reescalonamento de dívidas ainda durante a gestão de Cardoso. Não é possível afirmar, no entanto, se os valores renegociados se referem às mesmas dívidas, uma vez que os pareceres não evidenciam isso. 
Tabela 7: Descrição das dívidas de países da África com o Brasil negociadas pelo presidente Fernando Henrique Cardoso (1995-2002)

\begin{tabular}{|c|c|}
\hline País & Trechos retirados dos projetos de resoluções dos débitos \\
\hline República de Costa do Marfim (2002) & $\begin{array}{l}\text { Créditos oriundos de operações de financiamento do Fundo de Financiamento } \\
\text { à Exportação - FINEX. }\end{array}$ \\
\hline República de Moçambique (2002) & $\begin{array}{l}\text { Crédito proveniente de operações de financiamento às exportações realizadas } \\
\text { ao amparo do extinto FINEX. }\end{array}$ \\
\hline República Islâmica da Mauritânia (2002) & $\begin{array}{l}\text { Dívida decorre de convênios de crédito firmados com a extinta Carteira de } \\
\text { Comércio Exterior do Banco do Brasil - CACEX, que utilizou recursos do } \\
\text { extinto FINEX. }\end{array}$ \\
\hline República de Zâmbia (2001) & $\begin{array}{l}\text { Créditos decorrem de Convênios de Crédito firmados com a extinta Carteira de } \\
\text { Comércio Exterior do Banco do Brasil - CACEX, que utilizou recursos do } \\
\text { extinto FINEX. }\end{array}$ \\
\hline República da Costa do Marfim (2000) & $\begin{array}{l}\text { Créditos decorrem de Convênios de Crédito firmados com a extinta Carteira de } \\
\text { Comércio Exterior do Banco do Brasil - CACEX, que utilizou recursos do } \\
\text { também extinto FINEX. }\end{array}$ \\
\hline República Islâmica da Mauritânia (2000) & A dívida origina-se de empréstimos concedidos pelo extinto FINEX. \\
\hline República de Zâmbia (2000) & $\begin{array}{l}\text { O débito para com o governo brasileiro origina-se de "Convênios de Crédito" } \\
\text { que utilizaram recursos do FINEX. }\end{array}$ \\
\hline República de Gana (1999) & $\begin{array}{l}\text { A dívida teve origem em operações de financiamento à exportação realizadas } \\
\text { na década de mil novecentos e oitenta com recursos do extinto FINEX. }\end{array}$ \\
\hline República do Gabão (1997) & Operações realizadas ao amparo do extinto FINEX. \\
\hline República do Gabão (1996) & $\begin{array}{l}\text { Norma revogada posteriormente pela aprovação de projeto de resolução de } \\
1997 .\end{array}$ \\
\hline República Unida da Tanzânia (2001) & Os débitos são oriundos de financiamentos do FINEX. \\
\hline República de Cabo Verde (2000) & Débitos oriundos de financiamentos do FINEX. \\
\hline República de Moçambique (2000) & $\begin{array}{l}\text { Crédito proveniente de operação de financiamento à exportação realizadas no } \\
\text { âmbito do FINEX. }\end{array}$ \\
\hline
\end{tabular}

Fonte: Elaboração própria a partir da leitura dos pareceres apresentados no Senado Federal. As duas outras proposições apresentadas pelo presidente Cardoso sobre reescalonamento de dívida se referiam a créditos do Suriname.

O perdão e a renegociação de dívidas de países com o Brasil são possíveis graças à legislação aprovada no Congresso Nacional ainda durante o governo de Cardoso. Em 1998, a aprovação da Lei no 9.665 de 19 de junho de 1998 autorizou o Poder Executivo a conceder remissão parcial de créditos externos, em consonância com parâmetros estabelecidos nas Atas de Entendimentos originárias do chamado "Clube de Paris" ou em Memorandos de Entendimentos decorrentes de negociações bilaterais.

O Clube de Paris é uma instituição informal, sem personalidade jurídica, que reúne os principais Estados detentores de créditos externos oficiais, em geral membros da Organização 
para a Cooperação e Desenvolvimento Econômico (OCDE), com o propósito de renegociar a dívida governamental de países em dificuldade financeira. Embora não seja membro do Clube de Paris, o Brasil acompanha as discussões e procura utilizar os acordos firmados como parâmetro de referência para a renegociação de dívidas.

Quase todos os países africanos em processo de reescalonamento de dívidas com o Brasil estão incluídos no programa liderado pelo Banco Mundial, que criou o programa de Iniciativa da Dívida de Países Pobres Altamente Endividados (Heavily Indebted Poor Countries Debt Initiative - HIPC). O programa HIPC reúne países cuja dívida representa uma fração elevada de seu produto interno bruto e, assim, precisam de processos de negociação para reestruturação de seus débitos em termos mais favoráveis. A Iniciativa HIPC prevê o alívio da dívida externa dos países, a concessão de empréstimos concessionais e a adoção de um programa de ajuste estrutural que torne a dívida sustentável e permita implementar programas de desenvolvimento e de combate à pobreza (BRASIL, 2013b, p. 2).

Apesar das negociações de dívidas e dos acordos e parcerias assinados com a África no período, houve um leve declínio na corrente de comércio com o continente africano em 1998 e em 2002, final do governo de FHC. Para Ribeiro (2007), o declínio comercial Brasil-África articulou-se à própria retração no papel do Estado na economia, caracterizada pela desregulamentação e pela ampla privatização registradas ao longo do período (RIBEIRO, 2007, p.164).

Tabela 8: O comércio entre o Brasil e a África nos anos de governo FHC (1995-2002)

\begin{tabular}{|c|c|c|c|c|}
\hline & Exportação & Importação & Saldo & Corrente de Comércio \\
\hline Ano & US\$ FOB & US\$ FOB & US\$ FOB & US\$ FOB \\
\hline 1995 & 1.585 .821 .583 & 1.180 .637 .451 & 405.184 .132 & 2.766 .459 .034 \\
\hline 1996 & 1.527 .022 .348 & 1.690 .473 .093 & -163.450 .745 & 3.217 .495 .441 \\
\hline 1997 & 1.520 .000 .381 & 1.995 .198 .981 & -475.198 .600 & 3.515 .199 .362 \\
\hline 1998 & 1.651 .086 .046 & 1.819 .086 .788 & -168.000 .742 & 3.470 .172 .834 \\
\hline 1999 & 1.336 .476 .992 & 2.223 .842 .002 & -887.365 .010 & 3.560 .318 .994 \\
\hline 2000 & 1.347 .098 .183 & 2.907 .082 .676 & -1.559 .984 .493 & 4.254.180.859 \\
\hline 2001 & 1.989 .031 .346 & 3.330 .949 .802 & -1.341 .918 .456 & 5.319 .981 .148 \\
\hline 2002 & 2.363 .340 .654 & 2.675 .612 .821 & -312.272 .167 & 5.038 .953 .475 \\
\hline
\end{tabular}

Fonte: Elaboração própria a partir de dados do Aliceweb (BRASIL, 2014a).

Não obstante à queda das importações e, consequentemente, da corrente de comércio, houve um acréscimo nas exportações entre 1995 e 2002. A participação do continente africano 
nas vendas de mercadorias do Brasil para o exterior oscilou pouco durante os anos FHC. O percentual estava em 3,41\%, no início do governo, chegou a cair para 2,44\%, em 2000, e alcançou 3,91\% no final do governo. O valor absoluto das exportações para a África cresceu 49,03\%, passou de US\$ 1,5 bilhão, em 1995, para US\$ 2,3 bilhões, em 2002. Para Saraiva, a retomada de uma crescente pauta comercial com os países africanos se deu mesmo sem estímulo governamental (SARAIVA, 2002, p.11-12).

Gráfico 4: Participação das exportações para África no total das exportações do Brasil (19952002)

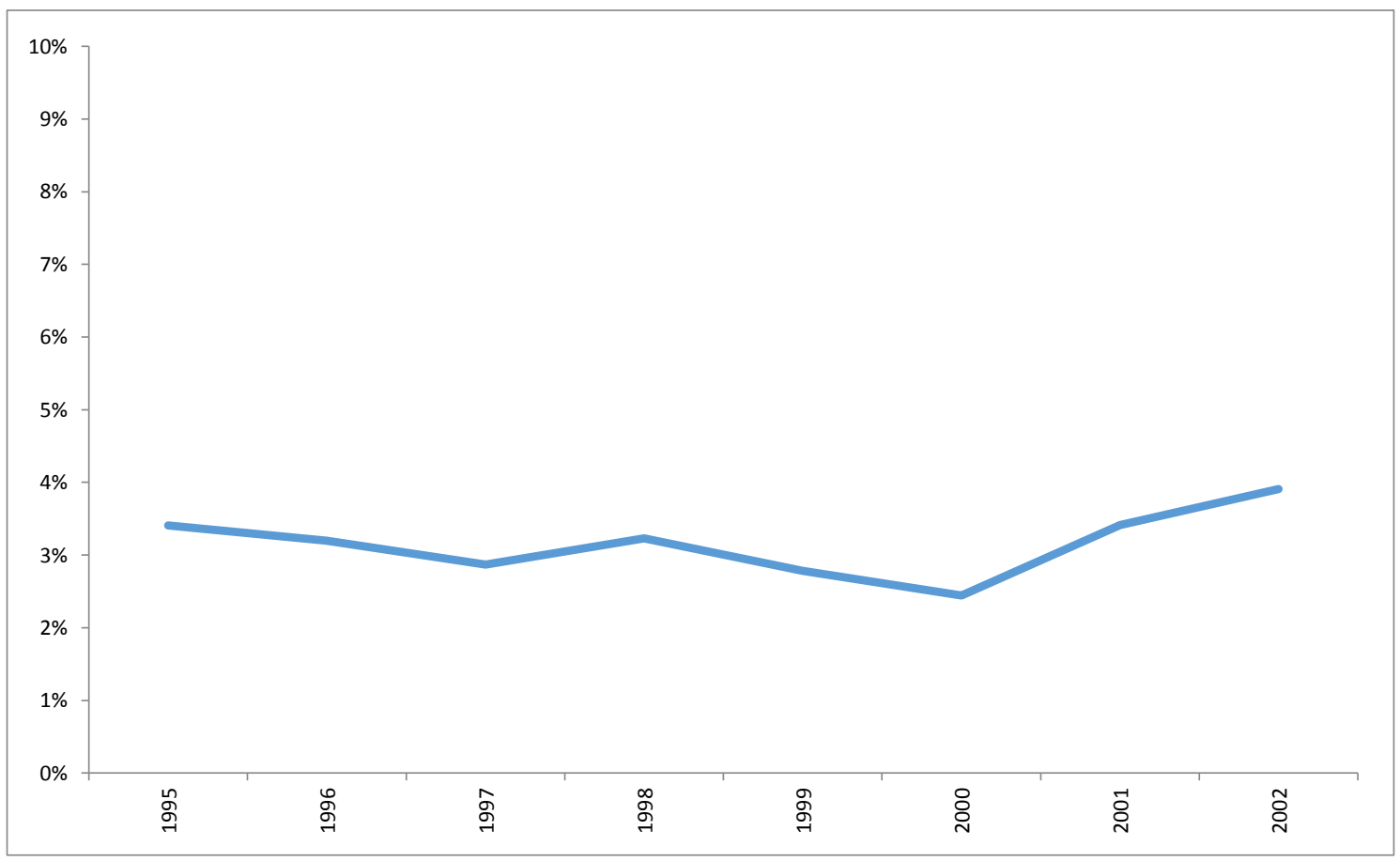

Fonte: Elaboração própria a partir de dados do Aliceweb (BRASIL, 2014a).

A análise da balança comercial, entre 1995 e 2002, revela que houve um aumento da proporção de produtos básicos no total de mercadorias vendidas. Os produtos exportados para a África classificados como básicos cresceram de 9,15\%, em 1995, para 17,86\%, em 2002. Houve queda principalmente no grupo dos semimanufaturados, que saíram de 34,45\% e foram para $13,85 \%$. Entre os produtos manufaturados, o percentual passou de $56,17 \%$ para $68,10 \%$. A piora do perfil das exportações acentuou-se nos governos Lula e Rousseff, quando o volume dos produtos básicos cresceu ainda mais. 
Gráfico 5: Perfil das exportações do Brasil para a África (1995-2002)

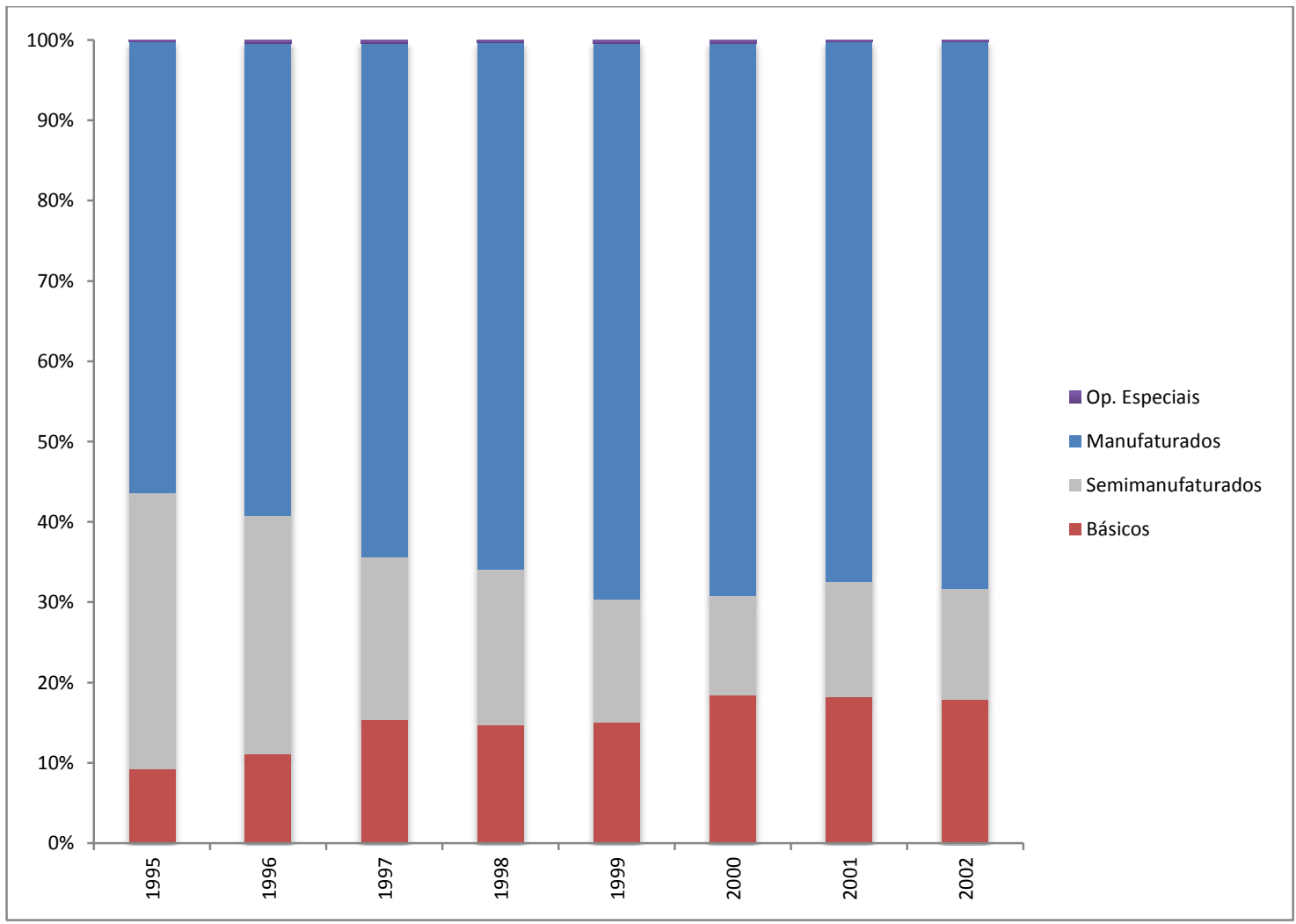

Fonte: Elaboração própria a partir de dados do Aliceweb (BRASIL, 2014a).

Tabela 9: Perfil das exportações do Brasil para a África em porcentagem (1995-2002)

\begin{tabular}{|c|c|c|c|c|}
\cline { 2 - 5 } \multicolumn{1}{c|}{} & Básicos & Semimanufaturados & Manufaturados & Op. Especiais \\
\hline 1995 & $9,15 \%$ & $34,45 \%$ & $56,17 \%$ & $0,23 \%$ \\
\hline 1996 & $11,04 \%$ & $29,75 \%$ & $58,81 \%$ & $0,41 \%$ \\
\hline 1997 & $15,41 \%$ & $20,18 \%$ & $63,99 \%$ & $0,41 \%$ \\
\hline 1998 & $14,73 \%$ & $19,35 \%$ & $65,65 \%$ & $0,27 \%$ \\
\hline 1999 & $15,03 \%$ & $15,37 \%$ & $69,18 \%$ & $0,43 \%$ \\
\hline 2000 & $18,50 \%$ & $12,27 \%$ & $68,75 \%$ & $0,48 \%$ \\
\hline 2001 & $18,23 \%$ & $14,25 \%$ & $67,30 \%$ & $0,23 \%$ \\
\hline 2002 & $17,86 \%$ & $13,85 \%$ & $68,10 \%$ & $0,19 \%$ \\
\hline
\end{tabular}

Fonte: Elaboração própria a partir de dados do Aliceweb (BRASIL, 2014a).

A avaliação dos produtos vendidos pelo Brasil para a África, no período entre 1997 e 2002, mostra uma grande concentração na venda de açúcares, que corresponderam a 24,12\% das exportações para o continente. O segundo item da pauta de exportações alcançou índice de $9,32 \%$, que equivaleu a vendas de açúcar de cana, em bruto. Os demais produtos na lista dos mais vendidos eram minérios de ferro aglomerados e seus concentrados, e óleo de soja em bruto. Em quinto lugar na lista, apareceram veículos automóveis com motor de pistão. Entre os 
dez produtos mais vendidos para a África, estavam semimanufaturados e manufaturados, em sua maioria. A análise das mercadorias vendidas para a África foi feita, neste trabalho, a partir de 1997 pelo fato de que, a partir desse ano, o Brasil mudou a forma de classificação dos produtos para adotar a Nomenclatura Comum do Mercosul (NCM). Antes disso, portanto, a classificação era feita de forma diferente.

Tabela 10: Lista dos vinte produtos mais vendidos para a África no governo FHC (1997*_ 2002)

\begin{tabular}{|c|c|c|c|c|c|}
\hline & NCM & Descrição & Fator Agregado & US\$ & Part. \\
\hline 1 & 17019900 & $\begin{array}{c}\text { Outros açúcares de } \\
\text { cana, beterraba, } \\
\text { sacarose quimicamente } \\
\text { pura, sol. }\end{array}$ & $\begin{array}{c}\text { PRODUTOS } \\
\text { MANUFATURADOS }\end{array}$ & 2.462 .362 .344 & $24,12 \%$ \\
\hline 2 & 17011100 & $\begin{array}{l}\text { Açúcar de cana, em } \\
\text { bruto }\end{array}$ & $\begin{array}{c}\text { PRODUTOS } \\
\text { SEMIMANUFATURADOS } \\
\end{array}$ & 951.101 .572 & $9,32 \%$ \\
\hline 3 & 26011200 & $\begin{array}{l}\text { Minérios de ferro } \\
\text { aglomerados e seus } \\
\text { concentrados }\end{array}$ & PRODUTOS BASICOS & 633.523 .351 & $6,21 \%$ \\
\hline 4 & 15071000 & $\begin{array}{c}\text { Óleo de soja, em bruto, } \\
\text { mesmo degomado }\end{array}$ & $\begin{array}{c}\text { PRODUTOS } \\
\text { SEMIMANUFATURADOS } \\
\end{array}$ & 379.015 .303 & $3,71 \%$ \\
\hline 5 & 87021000 & $\begin{array}{l}\text { Veículos automóveis } \\
\text { para transporte de dez } \\
\text { pessoas ou mais, } \\
\text { incluindo o motorista, } \\
\text { com motor de pistão, } \\
\text { de ignição por } \\
\text { compressão (diesel ou } \\
\text { semidiesel) }\end{array}$ & $\begin{array}{c}\text { PRODUTOS } \\
\text { MANUFATURADOS }\end{array}$ & 212.811 .011 & $2,08 \%$ \\
\hline 6 & 48025290 & $\begin{array}{c}\text { Outros papéis/cartões, } \\
\text { fibra obtida por } \\
\text { processo mecânico <= } \\
\begin{array}{c}10 \%, 40 \mathrm{~g} / \mathrm{m} 2<=\text { peso } \\
<=150 \mathrm{~g} / \mathrm{m} 2\end{array}\end{array}$ & $\begin{array}{c}\text { PRODUTOS } \\
\text { MANUFATURADOS }\end{array}$ & 162.370 .373 & $1,59 \%$ \\
\hline 7 & 87032290 & $\begin{array}{c}\text { Automóveis com motor } \\
\text { explosão, de cilindrada } \\
\text { superior a } 1.000 \mathrm{~cm} 3 \text {, } \\
\text { mas não superior a } \\
1.500 \mathrm{~cm} 3 \text {, superior a } 6 \\
\text { passageiros }\end{array}$ & $\begin{array}{c}\text { PRODUTOS } \\
\text { MANUFATURADOS }\end{array}$ & 158.085 .484 & $1,55 \%$ \\
\hline 8 & 02023000 & $\begin{array}{c}\text { Carnes desossadas de } \\
\text { bovino, congeladas }\end{array}$ & PRODUTOS BASICOS & 153.472 .125 & $1,50 \%$ \\
\hline 9 & 24012030 & $\begin{array}{c}\text { Tabaco não } \\
\text { manufaturado, total ou } \\
\text { parcialmente destalado, } \\
\text { em folhas secas em } \\
\text { secador de ar quente }\end{array}$ & PRODUTOS BASICOS & 134.290 .943 & $1,32 \%$ \\
\hline
\end{tabular}




\begin{tabular}{|c|c|c|c|c|c|}
\hline & & $\begin{array}{c}\text { (flue cured), do tipo } \\
\text { Virgínia }\end{array}$ & & & \\
\hline 10 & 27101159 & Outras gasolinas & $\begin{array}{c}\text { PRODUTOS } \\
\text { MANUFATURADOS }\end{array}$ & 131.190.772 & $1,29 \%$ \\
\hline 11 & 84292090 & Outros niveladores & $\begin{array}{c}\text { PRODUTOS } \\
\text { MANUFATURADOS }\end{array}$ & 128.187 .148 & $1,26 \%$ \\
\hline 12 & 27100029 & Outras gasolinas & $\begin{array}{c}\text { PRODUTOS } \\
\text { MANUFATURADOS }\end{array}$ & 117.343 .843 & $1,15 \%$ \\
\hline 13 & 09011110 & $\begin{array}{l}\text { Café não torrado, não } \\
\text { descafeinado, em grão }\end{array}$ & PRODUTOS BASICOS & 99.112 .061 & $0,97 \%$ \\
\hline 14 & 02071200 & $\begin{array}{c}\text { Carnes de } \\
\text { galos/galinhas, não } \\
\text { cortadas em pedaços, } \\
\text { congelala } \\
\end{array}$ & PRODUTOS BASICOS & 95.227 .812 & $0,93 \%$ \\
\hline 15 & 12010090 & $\begin{array}{l}\text { Outros grãos de soja, } \\
\text { mesmo triturados }\end{array}$ & PRODUTOS BASICOS & 93.821 .606 & $0,92 \%$ \\
\hline 16 & 84143011 & $\begin{array}{c}\text { Motocompressores } \\
\text { herméticos, com } \\
\text { capacidade inferior a } \\
4.700 \text { frigorias/hora, } \\
\text { dos tipos utilizados nos } \\
\text { equipamentos } \\
\text { frigoríficos } \\
\end{array}$ & $\begin{array}{c}\text { PRODUTOS } \\
\text { MANUFATURADOS }\end{array}$ & 92.911 .458 & $0,91 \%$ \\
\hline 17 & 10059010 & $\begin{array}{c}\text { Milho em grão, exceto } \\
\text { para semeadura }\end{array}$ & PRODUTOS BASICOS & 91.314 .659 & $0,89 \%$ \\
\hline 18 & 44071000 & $\begin{array}{c}\text { Madeira de coníferas, } \\
\text { serrada ou fendida } \\
\text { longitudinalmente, } \\
\text { cortada } \\
\text { transversalmente ou } \\
\text { desenrolada, mesmo } \\
\text { aplainada, lixada ou } \\
\text { unida pelas } \\
\text { extremidades, de } \\
\text { espessura superior a } 6 \\
\text { mm }\end{array}$ & $\begin{array}{c}\text { PRODUTOS } \\
\text { SEMIMANUFATURADOS }\end{array}$ & 77.810 .580 & $0,76 \%$ \\
\hline 19 & 29224220 & Sais do ácido glutâmico & $\begin{array}{c}\text { PRODUTOS } \\
\text { MANUFATURADOS }\end{array}$ & 77.389 .798 & $0,76 \%$ \\
\hline 20 & 87060010 & $\begin{array}{c}\text { Chassis com motor para } \\
\text { veículos automóveis } \\
\text { transporte pessoas }>= \\
10\end{array}$ & $\begin{array}{c}\text { PRODUTOS } \\
\text { MANUFATURADOS }\end{array}$ & 73.679 .003 & $0,72 \%$ \\
\hline
\end{tabular}

Fonte: Elaboração própria a partir de dados do Aliceweb (BRASIL, 2014a).

*A análise foi feita a partir de 1997 porque, a partir daquele ano, o Brasil mudou a forma de classificação dos produtos e adotou a Nomenclatura Comum do Mercosul (NCM). Antes disso, a classificação era feita de forma diferente.

Uma análise diferente do modelo de classificação por básico, semimanufaturado e manufaturado, adotado pelo Ministério do Desenvolvimento, Indústria e Comércio (MDIC), 
mostrou que muitas das mercadorias classificadas como detentoras de fator agregado são algumas vezes commodities beneficiadas, produtos submetidos a pequenos processos de beneficiamento industrial no Brasil; ou commodities industrializadas, produtos submetidos a processo de industrialização, mas que o exportador brasileiro não tem participação na negociação de seus preços de exportação, uma vez que são fixados em bolsas de mercadorias ou pelo mercado internacional (ASSOCIAÇÃO DE COMÉRCIO EXTERIOR DO BRASIL, 2012, p. 3-25). Essa constatação foi possível a partir do cruzamento de informações disponíveis na tabela de metodologia de produção de estatísticas de comércio exterior do MDIC que traz 353 produtos classificados como commodities e seus respectivos números na Nomenclatura Comum do Mercosul (NCM).

Açúcar de cana em bruto, óleo de soja em bruto, couro e pele bovina são exemplos de produtos classificados, pela convenção adotada pelo MDIC, como semimanufaturados; isso acontece porque a produção inclui valor de uma cadeia produtiva, ainda que não seja demasiadamente complexa. Suco de laranja, açúcares de cana, beterraba e sacarose quimicamente pura são exemplos de commodities consideradas pela classificação vigente como manufaturado, dividindo a mesma categoria de produtos aviões e veículos, cujas indústrias incorporam alta tecnologia.

O cruzamento de informações mostra que, de 1997 a 2002, a África comprou 176 tipos de commodities do Brasil. Sozinho, esse tipo de mercadoria vendida para a África totalizou $56,90 \%$ de todo o valor exportado, somados os seis anos entre 1997 a 2002. Em termos absolutos, de um total de US\$10,2 bilhões de exportações, US $\$ 5,8$ bilhões eram commodities, como açúcar, minério, soja e carne. 
Gráfico 6: As principais commodities vendidas para a África no governo FHC (1997*-2002)

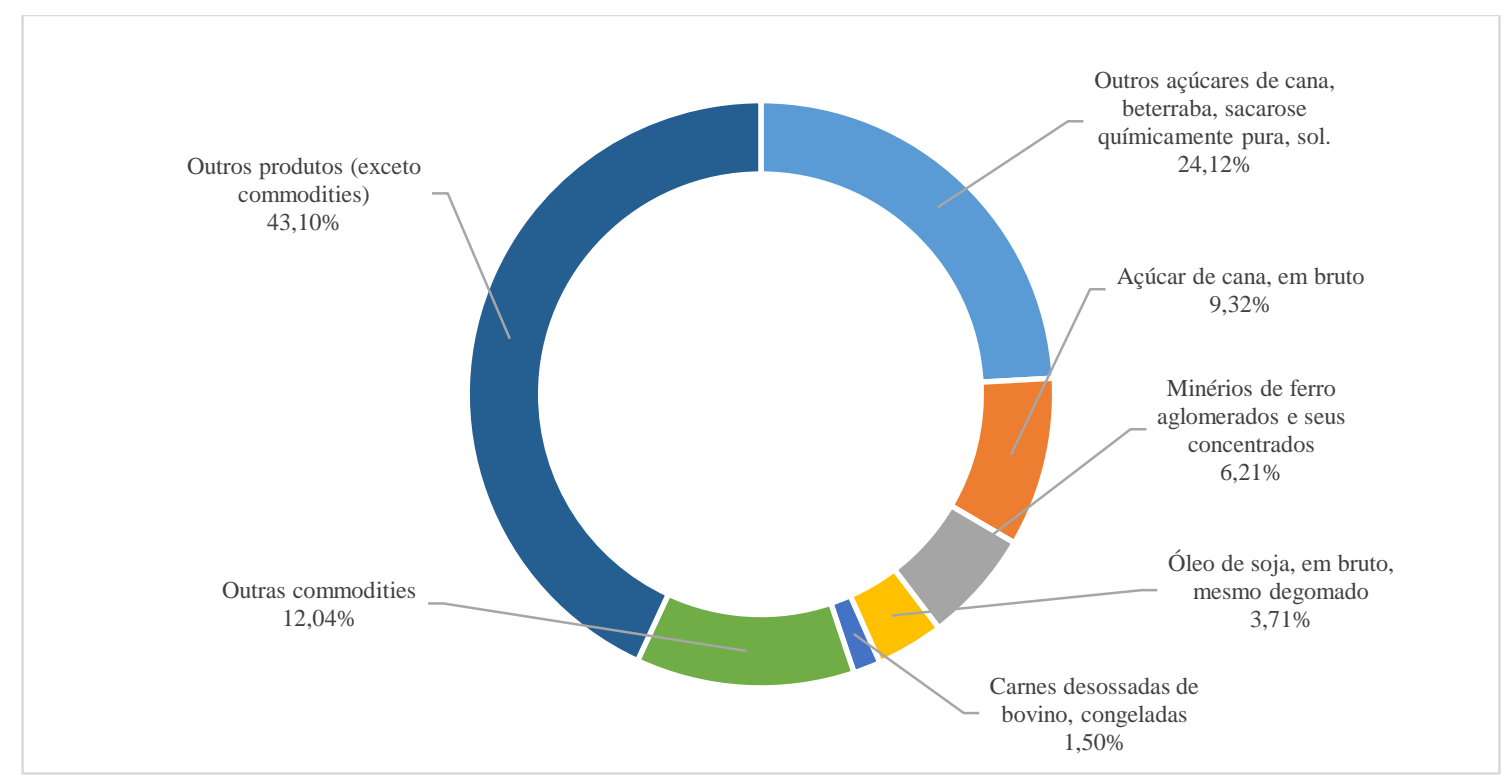

Fonte: Elaboração própria a partir de dados do Aliceweb (BRASIL, 2014a).

*A análise foi feita a partir de 1997 porque, a partir daquele ano, o Brasil mudou a forma de classificação dos produtos e adotou a Nomenclatura Comum do Mercosul (NCM). Antes disso, a classificação era feita de forma diferente.

Durante os oito anos da presidência de FHC, quatro países africanos estiveram na liderança como principais mercados para as exportações do Brasil. Egito, África do Sul, Nigéria e Marrocos aparecem no topo da lista de países que mais compraram produtos brasileiros entre 1995 e 2002. Sozinhos, os quatro representaram mais de $60 \%$ do total das exportações do Brasil para a África ao longo dos anos em estudo. Os quatro países aparecem em posições alternadas no ranking de principais mercados para os produtos brasileiros, como mostram as tabelas a seguir. Na quinta posição, revezaram-se Argélia e Angola, sempre com percentual de participação no comércio abaixo de dois dígitos.

Tabela 11: Os cinco principais destinos das mercadorias brasileiras na África entre 1995 e 2002 / Valores de exportação em dólar (US\$ FOB)

\begin{tabular}{|l|c|c|l|c|c|}
\hline País & $\mathbf{1 9 9 5}$ & Part. & País & $\mathbf{1 9 9 6}$ & Part. \\
\hline Egito & 369.666 .222 & $23 \%$ & África do Sul & 291.885 .594 & $19 \%$ \\
\hline África do Sul & 260.928 .028 & $16 \%$ & Nigéria & 274.540 .212 & $18 \%$ \\
\hline Nigéria & 243.327 .359 & $15 \%$ & Egito & 224.370 .607 & $15 \%$ \\
\hline Marrocos & 175.057 .263 & $11 \%$ & Marrocos & 162.102 .859 & $11 \%$ \\
\hline Argélia & 98.429 .557 & $6 \%$ & Argélia & 115.398 .735 & $8 \%$ \\
\hline
\end{tabular}




\begin{tabular}{|l|c|c|l|c|c|}
\hline País & $\mathbf{1 9 9 7}$ & Part. & País & $\mathbf{1 9 9 8}$ & Part. \\
\hline África do Sul & 331.624 .400 & $22 \%$ & Egito & 383.181 .340 & $23 \%$ \\
\hline Egito & 269.747 .428 & $18 \%$ & Nigéria & 328.038 .680 & $20 \%$ \\
\hline Nigéria & 249.172 .658 & $16 \%$ & África do Sul & 219.718 .260 & $13 \%$ \\
\hline Marrocos & 184.475 .303 & $12 \%$ & Marrocos & 193.482 .833 & $12 \%$ \\
\hline Angola & 81.794 .687 & $5 \%$ & Angola & 120.184 .100 & $7 \%$ \\
\hline
\end{tabular}

\begin{tabular}{|l|c|c|l|c|c|}
\hline País & $\mathbf{1 9 9 9}$ & Part. & País & $\mathbf{2 0 0 0}$ & Part. \\
\hline Egito & 291.877 .495 & $22 \%$ & África do Sul & 302.226 .889 & $22 \%$ \\
\hline África do Sul & 237.219 .071 & $18 \%$ & Nigéria & 246.861 .556 & $18 \%$ \\
\hline Nigéria & 226.811 .486 & $17 \%$ & Egito & 239.573 .595 & $18 \%$ \\
\hline Marrocos & 122.315 .824 & $9 \%$ & Marrocos & 138.637 .303 & $10 \%$ \\
\hline Angola & 64.115 .362 & $5 \%$ & Angola & 106.281 .536 & $8 \%$ \\
\hline
\end{tabular}

\begin{tabular}{|l|c|c|l|c|c|}
\hline País & $\mathbf{2 0 0 1}$ & Part. & País & $\mathbf{2 0 0 2}$ & Part. \\
\hline Egito & 424.553 .649 & $21 \%$ & Nigéria & 507.647 .903 & $21 \%$ \\
\hline África do Sul & 424.055 .007 & $21 \%$ & África do Sul & 478.190 .730 & $20 \%$ \\
\hline Nigéria & 416.870 .692 & $21 \%$ & Egito & 386.053 .503 & $16 \%$ \\
\hline Marrocos & 189.203 .808 & $10 \%$ & Marrocos & 235.009 .166 & $10 \%$ \\
\hline Angola & 142.008 .853 & $7 \%$ & Angola & 199.562 .411 & $8 \%$ \\
\hline
\end{tabular}

Fonte: Elaboração própria a partir de dados do Aliceweb (BRASIL, 2014a).

A análise dos principais compradores de produtos na África mostra uma alta concentração de parceiros comerciais. Entre os mais de cinquenta países africanos, apenas cinco compravam mais de 70\% do total de exportação do Brasil para o continente de 1995 a 2002. Entre os que mais consumiram produtos brasileiros no continente africano, estão os três apontados como prioritários pela política externa do Brasil para a África: África do Sul, Angola e Nigéria. De fato, em termos absolutos, houve um incremento do comércio. No caso da África do Sul, as exportações passaram de US\$260,9 milhões em 1995, para US\$ 478,1 milhões, em 2002; um crescimento de 83\%. As vendas para Angola foram de US\$ 20 milhões para US\$ 199,5 milhões, no mesmo período; cresceram o equivalente a quase dez vezes. As vendas para a Nigéria passaram de US\$243,3 milhões para US\$ 507,6 milhões, um aumento de 109\%. O perfil dos produtos mais vendidos para cada um dos seis países principais compradores será apresentado a seguir. 
Gráfico 7: Perfil dos principais produtos vendidos para África do Sul (1997-2002)

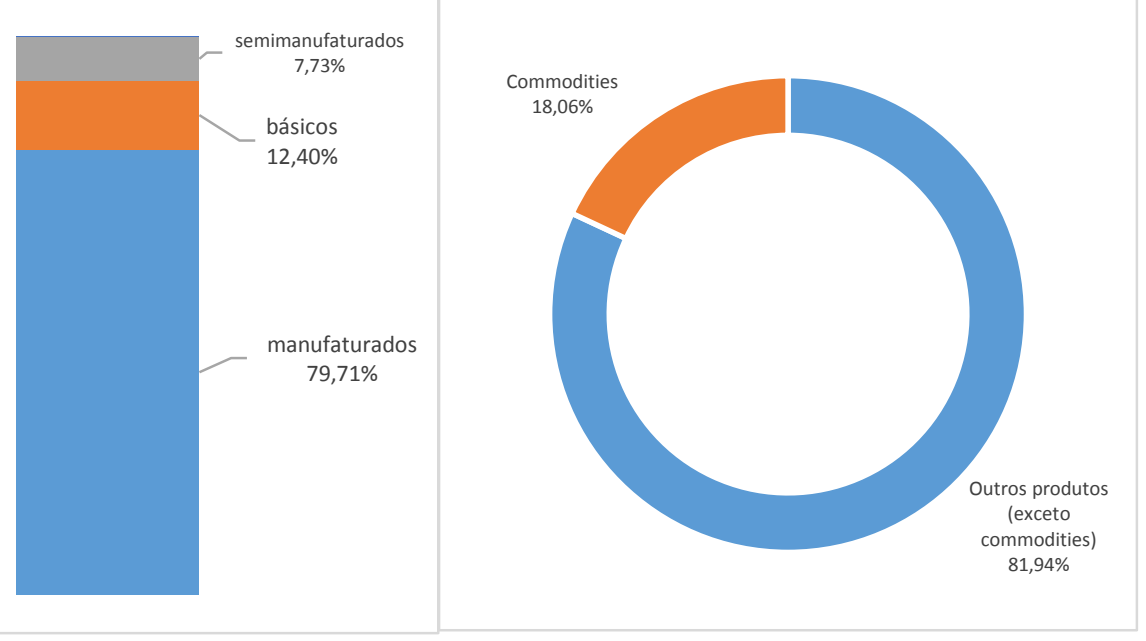

Fonte: Elaboração própria a partir de dados do Aliceweb (BRASIL, 2014a).

Os valores não somam $100 \%$ por causa das operações especiais.

Tabela 12: Lista dos principais produtos vendidos para África do Sul (1997-2002)

\begin{tabular}{|c|c|c|c|c|c|}
\hline & NCM & Descrição & Fator Agregado & US\$ & Part. \\
\hline 1 & 87032290 & $\begin{array}{c}\text { Automóveis com motor explosão, de } \\
\text { cilindrada superior a } 1.000 \mathrm{~cm} 3 \text {, mas } \\
\text { não superior a } 1.500 \mathrm{~cm} 3 \text {, superior a } 6 \\
\text { passageiros }\end{array}$ & $\begin{array}{c}\text { PRODUTOS } \\
\text { MANUFATURADOS }\end{array}$ & 157.731.188 & $7,91 \%$ \\
\hline 2 & 88023090 & $\begin{array}{c}\text { Outros aviões/veículos aéreos, } 2000 \mathrm{~kg} \\
<\text { peso <= } 15000 \mathrm{~kg} \text {, vazios }\end{array}$ & $\begin{array}{c}\text { PRODUTOS } \\
\text { MANUFATURADOS }\end{array}$ & 66.323 .436 & $3,33 \%$ \\
\hline 3 & 87032390 & $\begin{array}{l}\text { Automóveis com motor explosão, } 1500 \\
<\mathrm{cm} 3<=3000 \text {, superior a } 6 \text { passageiros }\end{array}$ & $\begin{array}{c}\text { PRODUTOS } \\
\text { MANUFATURADOS }\end{array}$ & 65.061 .017 & $2,85 \%$ \\
\hline 4 & 26011200 & $\begin{array}{l}\text { Minérios de ferro aglomerados e seus } \\
\text { concentrados }\end{array}$ & $\begin{array}{l}\text { PRODUTOS } \\
\text { BASICOS }\end{array}$ & 56.888 .716 & $2,63 \%$ \\
\hline 5 & 84143011 & $\begin{array}{l}\text { Motocompressores herméticos, com } \\
\text { capacidade inferior a } 4.700 \\
\text { frigorias/hora, dos tipos utilizados nos } \\
\text { equipamentos frigoríficos }\end{array}$ & $\begin{array}{c}\text { PRODUTOS } \\
\text { MANUFATURADOS }\end{array}$ & 52.410 .459 & $2,52 \%$ \\
\hline 6 & 87019000 & Outros tratores & $\begin{array}{c}\text { PRODUTOS } \\
\text { MANUFATURADOS } \\
\end{array}$ & 50.251 .521 & $2,11 \%$ \\
\hline 7 & 87021000 & $\begin{array}{c}\text { Veículos automóveis para transporte de } \\
\text { dez pessoas ou mais, incluindo o } \\
\text { motorista, com motor de pistão, de } \\
\text { ignição por compressão (diesel ou } \\
\text { semidiesel) }\end{array}$ & $\begin{array}{c}\text { PRODUTOS } \\
\text { MANUFATURADOS }\end{array}$ & 42.041 .546 & $1,99 \%$ \\
\hline 8 & 27100029 & Outras gasolinas & $\begin{array}{c}\text { PRODUTOS } \\
\text { MANUFATURADOS }\end{array}$ & 39.723 .436 & $1,87 \%$ \\
\hline 9 & 87089990 & $\begin{array}{c}\text { Outras partes e acessórios para tratores } \\
\text { e veículos automóveis }\end{array}$ & $\begin{array}{c}\text { PRODUTOS } \\
\text { MANUFATURADOS }\end{array}$ & 37.304 .084 & $1,83 \%$ \\
\hline 10 & 02071400 & $\begin{array}{l}\text { Pedaços e miudezas, comestíveis de } \\
\text { galos/galinhas, congelados }\end{array}$ & $\begin{array}{l}\text { PRODUTOS } \\
\text { BASICOS }\end{array}$ & 36.384 .496 & $0,00 \%$ \\
\hline
\end{tabular}

Fonte: Elaboração própria a partir de dados do Aliceweb (BRASIL, 2014a). 
Gráfico 8: Perfil dos principais produtos vendidos para Angola (1997-2002)

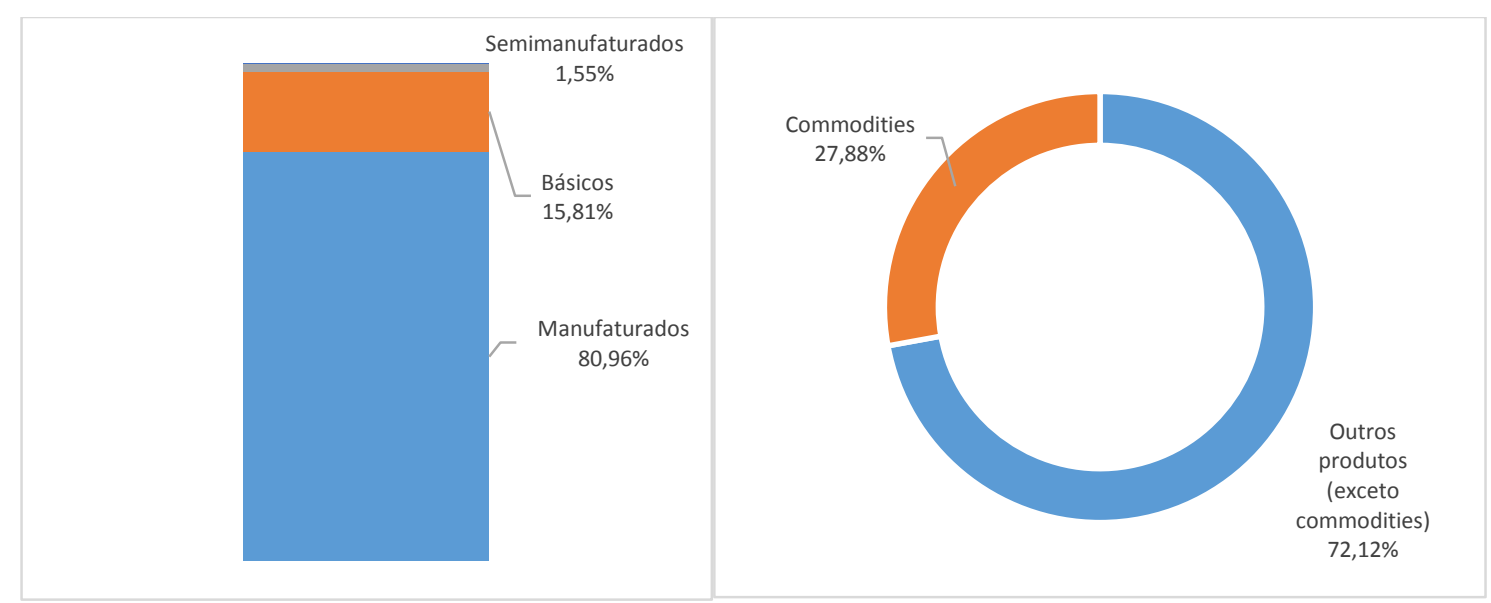

Fonte: Elaboração própria a partir de dados do Aliceweb (BRASIL, 2014a).

Os valores não somam $100 \%$ por causa das operações especiais.

Tabela 13: Lista dos principais produtos vendidos para Angola (1997-2002)

\begin{tabular}{|c|c|c|c|c|c|}
\hline & NCM & Descrição & Fator Agregado & US\$ & Part. \\
\hline 1 & 17019900 & $\begin{array}{l}\text { Outros açúcares de cana, } \\
\text { beterraba, sacarose } \\
\text { quimicamente pura, sol. }\end{array}$ & $\begin{array}{c}\text { PRODUTOS } \\
\text { MANUFATURADOS }\end{array}$ & 106.705 .685 & $14,95 \%$ \\
\hline 2 & 02071200 & $\begin{array}{c}\text { Carnes de galos/galinhas, não } \\
\text { cortadas em pedaços, } \\
\text { congelala }\end{array}$ & PRODUTOS BASICOS & 58.361 .061 & $8,17 \%$ \\
\hline 3 & 88023029 & $\begin{array}{c}\text { Aviões e outros veículos } \\
\text { aéreos, } 7 \text { toneladas }<\text { peso }<= \\
15 \text { toneladas, vazios, a } \\
\text { turboélice }\end{array}$ & $\begin{array}{c}\text { PRODUTOS } \\
\text { MANUFATURADOS }\end{array}$ & 21.192 .000 & $2,97 \%$ \\
\hline 4 & 87021000 & $\begin{array}{l}\text { Veículos automóveis para } \\
\text { transporte de dez pessoas ou } \\
\text { mais, incluindo o motorista, } \\
\text { com motor de pistão, de } \\
\text { ignição por compressão } \\
\text { (diesel ou semidiesel) }\end{array}$ & $\begin{array}{c}\text { PRODUTOS } \\
\text { MANUFATURADOS }\end{array}$ & 19.763 .540 & $2,77 \%$ \\
\hline 5 & 02102000 & $\begin{array}{c}\text { Carnes de bovinos, } \\
\text { salgadas/em } \\
\text { salmoura/secas/defumadas }\end{array}$ & PRODUTOS BASICOS & 18.486 .768 & $2,59 \%$ \\
\hline 6 & 04029900 & $\begin{array}{c}\text { Outros leites, cremes de leite, } \\
\text { concentrados, adocicados }\end{array}$ & $\begin{array}{c}\text { PRODUTOS } \\
\text { MANUFATURADOS }\end{array}$ & 15.832 .596 & $2,22 \%$ \\
\hline 7 & 73030000 & $\begin{array}{l}\text { Tubos e perfis ocos, de ferro } \\
\text { fundido }\end{array}$ & $\begin{array}{c}\text { PRODUTOS } \\
\text { MANUFATURADOS }\end{array}$ & 13.898 .051 & $1,95 \%$ \\
\hline 8 & 17011100 & Açúcar de cana, em bruto & $\begin{array}{c}\text { PRODUTOS } \\
\text { SEMIMANUFATURADOS }\end{array}$ & 12.449 .812 & $1,74 \%$ \\
\hline 9 & 02023000 & $\begin{array}{l}\text { Carnes desossadas de bovino, } \\
\text { congeladas }\end{array}$ & PRODUTOS BASICOS & 12.384 .312 & $1,73 \%$ \\
\hline 10 & 87053000 & $\begin{array}{l}\text { Veículos automóveis de } \\
\text { combate a incêndios }\end{array}$ & $\begin{array}{c}\text { PRODUTOS } \\
\text { MANUFATURADOS }\end{array}$ & 11.983 .846 & $1,68 \%$ \\
\hline
\end{tabular}

Fonte: Elaboração própria a partir de dados do Aliceweb (BRASIL, 2014a). 
Gráfico 9: Perfil dos principais produtos vendidos para Argélia (1997-2002)

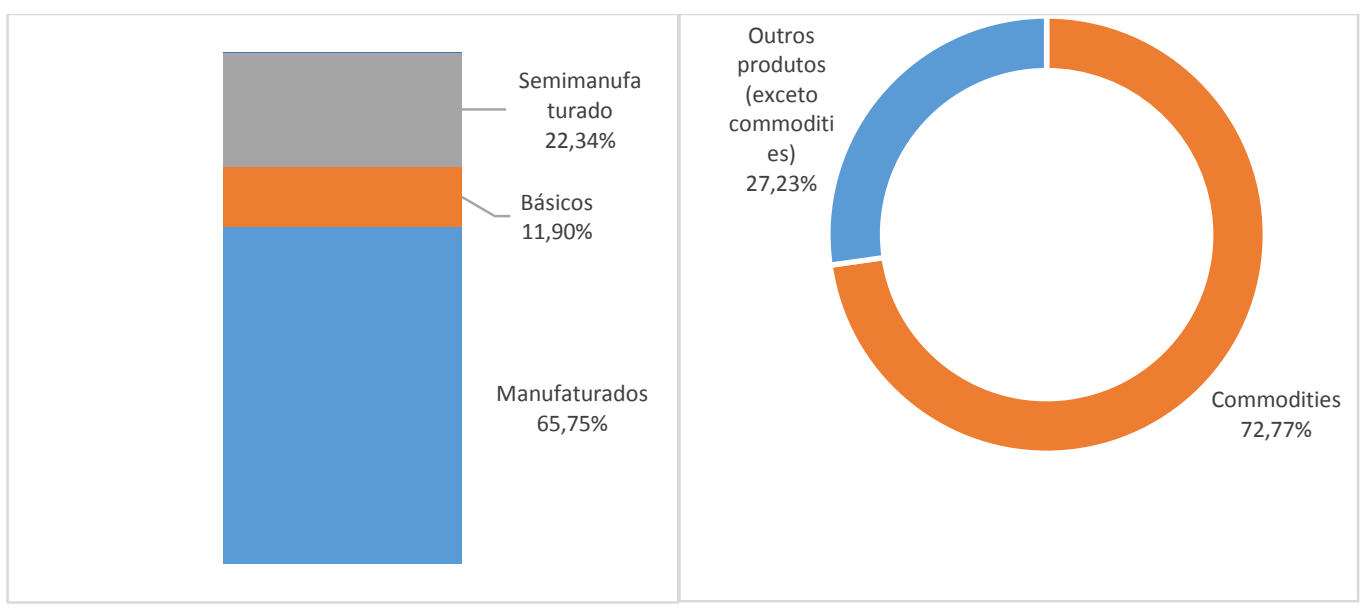

Fonte: Elaboração própria a partir de dados do Aliceweb (BRASIL, 2014a).

Os valores não somam $100 \%$ por causa das operações especiais.

Tabela 14: Lista dos principais produtos vendidos para Argélia (1997-2002)

\begin{tabular}{|c|c|c|c|c|c|}
\hline & NCM & Descrição & Fator Agregado & US\$ & Part. \\
\hline 1 & 17019900 & $\begin{array}{c}\text { Outros açúcares de cana, } \\
\text { beterraba, sacarose quimicamente } \\
\text { pura, sol. }\end{array}$ & $\begin{array}{l}\text { PRODUTOS } \\
\text { MANUFATURADOS }\end{array}$ & 120.240 .679 & $38,68 \%$ \\
\hline 2 & 17011100 & Açúcar de cana, em bruto & $\begin{array}{c}\text { PRODUTOS } \\
\text { SEMIMANUFATURADOS }\end{array}$ & 65.991 .547 & $21,23 \%$ \\
\hline 3 & 73041090 & $\begin{array}{c}\text { Outros tubos de ferro/aço, sem } \\
\text { costura, para oleodutos/gasodutos }\end{array}$ & $\begin{array}{c}\text { PRODUTOS } \\
\text { MANUFATURADOS }\end{array}$ & 23.193 .165 & $7,46 \%$ \\
\hline 4 & 48025290 & $\begin{array}{l}\text { Outros papéis/cartões, fibra obtida } \\
\text { por processo mecânico <= } 10 \%, 40 \\
\mathrm{~g} / \mathrm{m} 2<=\text { peso }<=150 \mathrm{~g} / \mathrm{m} 2\end{array}$ & $\begin{array}{c}\text { PRODUTOS } \\
\text { MANUFATURADOS }\end{array}$ & 17.432 .067 & $5,61 \%$ \\
\hline 5 & 09011110 & $\begin{array}{l}\text { Café não torrado, não } \\
\text { descafeinado, em grão }\end{array}$ & PRODUTOS BASICOS & 12.108 .455 & $3,90 \%$ \\
\hline 6 & 10059010 & $\begin{array}{l}\text { Milho em grão, exceto para } \\
\text { semeadura }\end{array}$ & PRODUTOS BASICOS & 11.251 .200 & $3,62 \%$ \\
\hline 7 & 93062100 & $\begin{array}{c}\text { Cartuchos para espingardas ou } \\
\text { carabinas de cano liso }\end{array}$ & $\begin{array}{c}\text { PRODUTOS } \\
\text { MANUFATURADOS }\end{array}$ & 5.267 .100 & $1,69 \%$ \\
\hline 8 & 04021090 & $\begin{array}{l}\text { Outros leites e cremes, em pó, } \\
\text { com um teor, em peso, de } \\
\text { matérias gordas, não superior a } \\
1,5 \% \text {, concentrados ou } \\
\text { adicionados de açúcar ou de } \\
\text { outros edulcorantes }\end{array}$ & $\begin{array}{c}\text { PRODUTOS } \\
\text { MANUFATURADOS }\end{array}$ & 4.354 .480 & $1,40 \%$ \\
\hline 9 & 24011090 & $\begin{array}{c}\text { Outros tabacos não } \\
\text { manufaturados, não destalados }\end{array}$ & PRODUTOS BASICOS & 4.193 .000 & $1,35 \%$ \\
\hline 10 & 24012030 & $\begin{array}{l}\text { Tabaco não manufaturado, total } \\
\text { ou parcialmente destalado, em } \\
\text { folhas secas em secador de ar } \\
\text { quente (flue cured), do tipo } \\
\text { Virgínia }\end{array}$ & PRODUTOS BASICOS & 4.177 .624 & $1,34 \%$ \\
\hline
\end{tabular}

Fonte: Elaboração própria a partir de dados do Aliceweb (BRASIL, 2014a). 
Gráfico 10: Perfil dos principais produtos vendidos para o Egito (1997-2002)

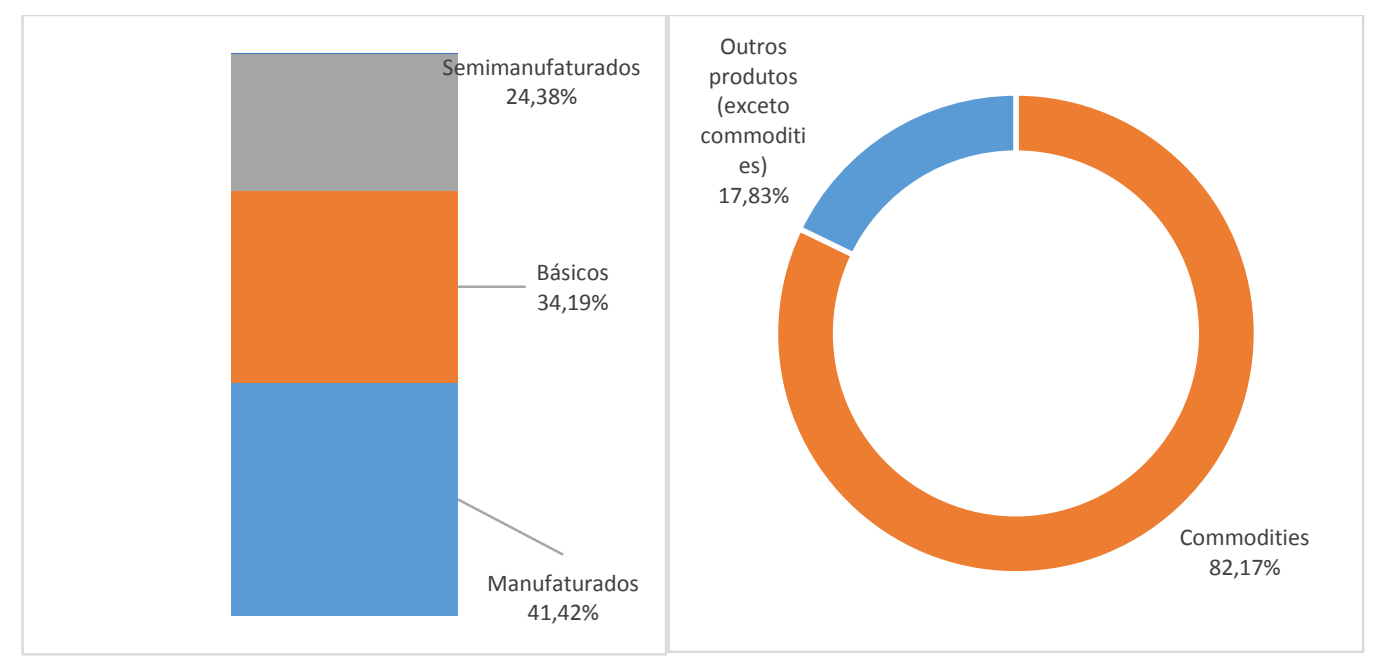

Fonte: Elaboração própria a partir de dados do Aliceweb (BRASIL, 2014a).

Os valores não somam $100 \%$ por causa das operações especiais.

Tabela 15: Lista dos principais produtos vendidos para o Egito (1997-2002)

\begin{tabular}{|c|c|c|c|c|c|}
\hline & NCM & Descrição & Fator Agregado & US\$ & Part. \\
\hline 1 & 17019900 & $\begin{array}{l}\text { Outros açúcares de cana, beterraba, } \\
\text { sacarose quimicamente pura, sol. }\end{array}$ & $\begin{array}{c}\text { PRODUTOS } \\
\text { MANUFATURADOS }\end{array}$ & 465.762 .443 & $23,35 \%$ \\
\hline 2 & 26011200 & $\begin{array}{l}\text { Minérios de ferro aglomerados e seus } \\
\text { concentrados }\end{array}$ & PRODUTOS BASICOS & 393.522 .735 & $19,73 \%$ \\
\hline 3 & 17011100 & Açúcar de cana, em bruto & $\begin{array}{c}\text { PRODUTOS } \\
\text { SEMIMANUFATURADOS }\end{array}$ & 336.908 .761 & $16,89 \%$ \\
\hline 4 & 15071000 & $\begin{array}{c}\text { Óleo de soja, em bruto, mesmo } \\
\text { degomado }\end{array}$ & $\begin{array}{c}\text { PRODUTOS } \\
\text { SEMIMANUFATURADOS }\end{array}$ & 138.088 .256 & $6,92 \%$ \\
\hline 5 & 02023000 & $\begin{array}{l}\text { Carnes desossadas de bovino, } \\
\text { congeladas }\end{array}$ & PRODUTOS BASICOS & 137.498 .452 & $6,89 \%$ \\
\hline 6 & 24012030 & $\begin{array}{l}\text { Tabaco não manufaturado, total ou } \\
\text { parcialmente destalado, em folhas } \\
\text { secas em secador de ar quente (flue } \\
\text { cured), do tipo Virgínia }\end{array}$ & PRODUTOS BASICOS & 60.846 .155 & $3,05 \%$ \\
\hline 7 & 48025290 & $\begin{array}{l}\text { Outros papéis/cartões, fibra obtida } \\
\text { por processo mecânico }<=10 \%, 40 \\
\mathrm{~g} / \mathrm{m} 2<=\text { peso }<=150 \mathrm{~g} / \mathrm{m} 2\end{array}$ & $\begin{array}{c}\text { PRODUTOS } \\
\text { MANUFATURADOS }\end{array}$ & 55.640 .402 & $2,79 \%$ \\
\hline 8 & 84143011 & $\begin{array}{c}\text { Motocompressores herméticos, com } \\
\text { capacidade inferior a } 4.700 \\
\text { frigorias/hora, dos tipos utilizados } \\
\text { nos equipamentos frigoríficos }\end{array}$ & $\begin{array}{l}\text { PRODUTOS } \\
\text { MANUFATURADOS }\end{array}$ & 38.291 .929 & $1,92 \%$ \\
\hline 9 & 73051100 & $\begin{array}{c}\text { Tubos dos tipos utilizados em } \\
\text { oleodutos ou gasodutos, soldados } \\
\text { longitudinalmente por arco imerso, } \\
\text { de seção circular, de diâmetro } \\
\text { exterior superior a } 406,4 \mathrm{~mm} \text {, de } \\
\text { ferro ou aço }\end{array}$ & $\begin{array}{l}\text { PRODUTOS } \\
\text { MANUFATURADOS }\end{array}$ & 24.889 .341 & $1,25 \%$ \\
\hline 10 & 87060010 & $\begin{array}{l}\text { Chassis com motor para veículos } \\
\text { automóveis transporte pessoas >= } 10\end{array}$ & $\begin{array}{c}\text { PRODUTOS } \\
\text { MANUFATURADOS }\end{array}$ & 20.230 .194 & $1,01 \%$ \\
\hline
\end{tabular}

Fonte: Elaboração própria a partir de dados do Aliceweb (BRASIL, 2014a). 
Gráfico 11: Perfil dos principais produtos vendidos para o Marrocos (1997-2002)

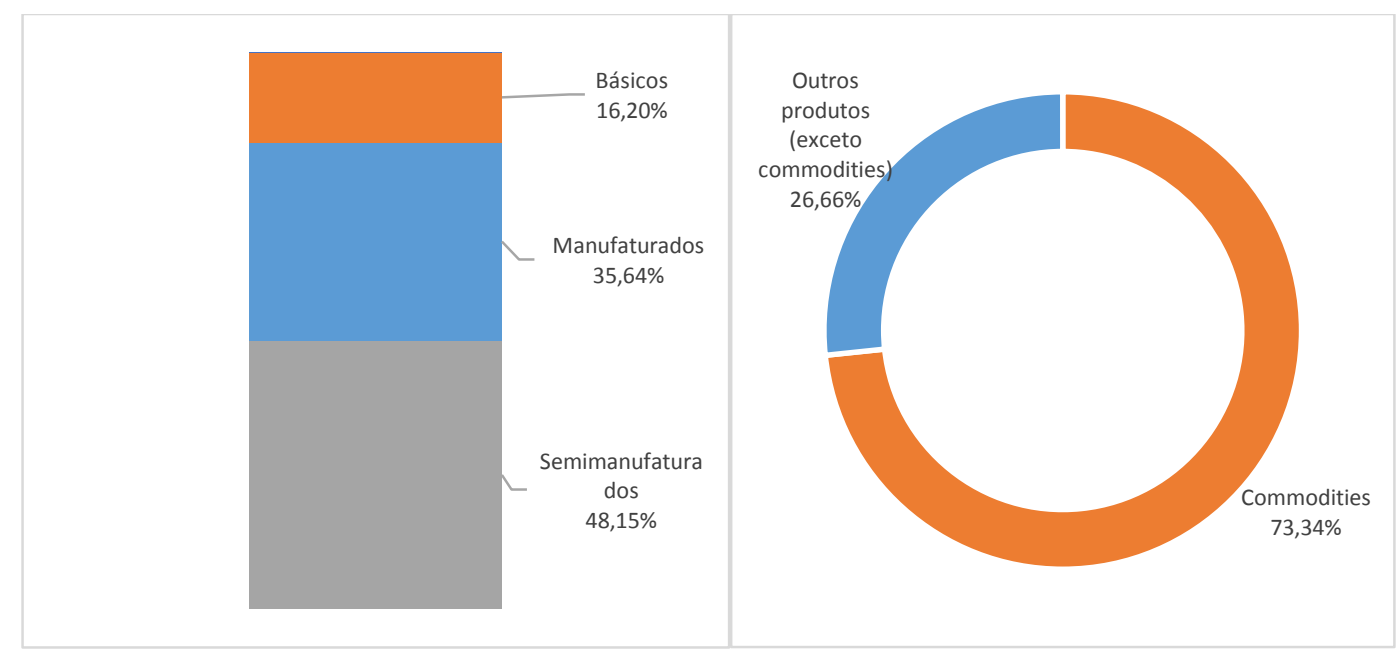

Fonte: Elaboração própria a partir de dados do Aliceweb (BRASIL, 2014a).

Os valores não somam $100 \%$ por causa das operações especiais.

Tabela 16: Lista dos principais produtos vendidos para o Marrocos (1997-2002)

\begin{tabular}{|c|c|c|c|c|c|}
\hline & NCM & Descrição & Fator Agregado & US\$ & Part. \\
\hline 1 & 17011100 & Açúcar de cana, em bruto & $\begin{array}{c}\text { PRODUTOS } \\
\text { SEMIMANUFATURADOS }\end{array}$ & 289.444 .948 & $27,23 \%$ \\
\hline 2 & 17019900 & $\begin{array}{l}\text { Outros açúcares de cana, beterraba, } \\
\text { sacarose quimicamente pura, sol. }\end{array}$ & $\begin{array}{c}\text { PRODUTOS } \\
\text { MANUFATURADOS }\end{array}$ & 181.276 .158 & $17,05 \%$ \\
\hline 3 & 15071000 & $\begin{array}{l}\text { Óleo de soja, em bruto, mesmo } \\
\text { degomado }\end{array}$ & $\begin{array}{c}\text { PRODUTOS } \\
\text { SEMIMANUFATURADOS }\end{array}$ & 126.312 .611 & $11,88 \%$ \\
\hline 4 & 12010090 & $\begin{array}{l}\text { Outros grãos de soja, mesmo } \\
\text { triturados }\end{array}$ & PRODUTOS BASICOS & 83.723 .064 & $7,88 \%$ \\
\hline 5 & 44071000 & $\begin{array}{l}\text { Madeira de coníferas, serrada ou } \\
\text { fendida longitudinalmente, cortada } \\
\text { transversalmente ou desenrolada, } \\
\text { mesmo aplainada, lixada ou unida } \\
\text { pelas extremidades, de espessura } \\
\text { superior a } 6 \mathrm{~mm}\end{array}$ & $\begin{array}{c}\text { PRODUTOS } \\
\text { SEMIMANUFATURADOS }\end{array}$ & 76.575 .569 & $7,20 \%$ \\
\hline 6 & 44152000 & $\begin{array}{l}\text { Paletes simples, paletes-caixas e } \\
\text { outros estrados para carga; taipais } \\
\text { de paletes; de madeira }\end{array}$ & $\begin{array}{c}\text { PRODUTOS } \\
\text { MANUFATURADOS }\end{array}$ & 21.879.359 & $2,06 \%$ \\
\hline 7 & 10059010 & $\begin{array}{l}\text { Milho em grão, exceto para } \\
\text { semeadura }\end{array}$ & PRODUTOS BASICOS & 18.815 .270 & $1,77 \%$ \\
\hline 8 & 44039900 & $\begin{array}{l}\text { Outras madeiras em bruto, mesmo } \\
\text { descascada, desalburnada ou } \\
\text { esquadriada }\end{array}$ & PRODUTOS BASICOS & 16.578 .636 & $1,56 \%$ \\
\hline 9 & 23040090 & $\begin{array}{l}\text { Bagaços e outros resíduos sólidos, } \\
\text { da extração do óleo de soja }\end{array}$ & PRODUTOS BASICOS & 16.431 .875 & $1,55 \%$ \\
\hline 10 & 72101200 & $\begin{array}{l}\text { Produtos laminados planos, de ferro } \\
\text { ou aço não ligado, de largura igual } \\
\text { ou superior a } 600 \mathrm{~mm} \text {, folheados ou } \\
\text { chapeados, ou revestidos, } \\
\text { estanhados, de espessura inferior a } \\
0,5 \mathrm{~mm}\end{array}$ & $\begin{array}{c}\text { PRODUTOS } \\
\text { MANUFATURADOS }\end{array}$ & 15.408 .289 & $1,45 \%$ \\
\hline
\end{tabular}

Fonte: Elaboração própria a partir de dados do Aliceweb (BRASIL, 2014a). 
Gráfico 12: Perfil dos principais produtos vendidos para a Nigéria (1997-2002)

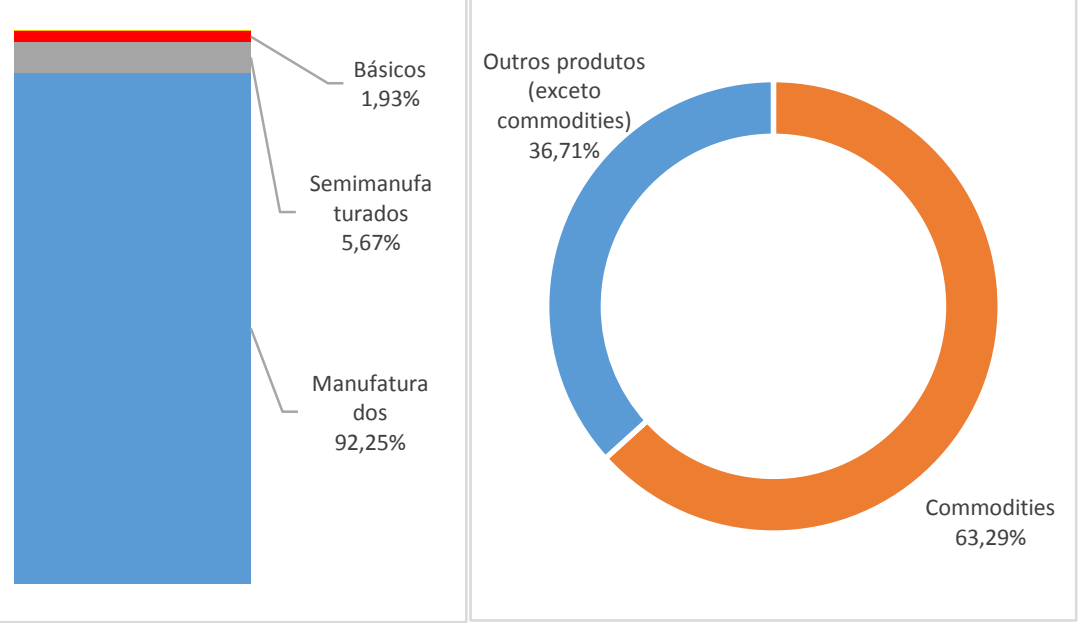

Fonte: Elaboração própria a partir de dados do Aliceweb (BRASIL, 2014a).

Os valores não somam $100 \%$ por causa das operações especiais.

Tabela 17: Lista dos principais produtos vendidos para a Nigéria (1997-2002)

\begin{tabular}{|c|c|c|c|c|c|}
\hline & NCM & Descrição & Fator Agregado & US\$ & Part. \\
\hline 1 & 17019900 & $\begin{array}{l}\text { Outros açúcares de cana, } \\
\text { beterraba, sacarose } \\
\text { quimicamente pura, sol. }\end{array}$ & $\begin{array}{c}\text { PRODUTOS } \\
\text { MANUFATURADOS }\end{array}$ & 913.870 .958 & $46,26 \%$ \\
\hline 2 & 87021000 & $\begin{array}{c}\text { Veículos automóveis para } \\
\text { transporte de dez pessoas ou } \\
\text { mais, incluindo o motorista, } \\
\text { com motor de pistão, de ignição } \\
\text { por compressão (diesel ou } \\
\text { semidiesel) }\end{array}$ & $\begin{array}{c}\text { PRODUTOS } \\
\text { MANUFATURADOS }\end{array}$ & 144.210 .263 & $7,30 \%$ \\
\hline 3 & 27101159 & Outras gasolinas & $\begin{array}{c}\text { PRODUTOS } \\
\text { MANUFATURADOS }\end{array}$ & 131.190.772 & $6,64 \%$ \\
\hline 4 & 17011100 & Açúcar de cana, em bruto & $\begin{array}{c}\text { PRODUTOS } \\
\text { SEMIMANUFATURADOS }\end{array}$ & 94.720 .502 & $4,79 \%$ \\
\hline 5 & 27100029 & Outras gasolinas & $\begin{array}{c}\text { PRODUTOS } \\
\text { MANUFATURADOS }\end{array}$ & 68.172 .993 & $3,45 \%$ \\
\hline 6 & 48025290 & $\begin{array}{c}\text { Outros papéis/cartões, fibra } \\
\text { obtida por processo mecânico } \\
<=10 \%, 40 \mathrm{~g} / \mathrm{m} 2<=\text { peso <=150 } \\
\mathrm{g} / \mathrm{m} 2\end{array}$ & $\begin{array}{c}\text { PRODUTOS } \\
\text { MANUFATURADOS }\end{array}$ & 48.074 .544 & $2,43 \%$ \\
\hline 7 & 27100061 & Óleos lubrificantes sem aditivos & $\begin{array}{c}\text { PRODUTOS } \\
\text { MANUFATURADOS }\end{array}$ & 37.838 .314 & $1,92 \%$ \\
\hline 8 & 25010011 & $\begin{array}{c}\text { Sal marinho, a granel, sem } \\
\text { agregados }\end{array}$ & PRODUTOS BASICOS & 28.538 .677 & $1,44 \%$ \\
\hline 9 & 87042210 & $\begin{array}{c}\text { Chassis com motor diesel e } \\
\text { cabina, } 5 \text { toneladas < carga <= } \\
20 \text { toneladas }\end{array}$ & $\begin{array}{c}\text { PRODUTOS } \\
\text { MANUFATURADOS }\end{array}$ & 27.650 .376 & $1,40 \%$ \\
\hline 10 & 29224220 & Sais do ácido glutâmico & $\begin{array}{c}\text { PRODUTOS } \\
\text { MANUFATURADOS }\end{array}$ & 26.768 .940 & $1,36 \%$ \\
\hline
\end{tabular}

Fonte: Elaboração própria a partir de dados do Aliceweb (BRASIL, 2014a). 
O perfil das mercadorias vendidas para a África do Sul foi o mais positivo na comparação entre os seis principais mercados de destino de mercadorias brasileiras no continente africano. Entre 1997 e 2002, o equivalente a 79,71\% dos produtos vendidos eram de manufaturados, com apenas 18,06\% de commodities. Além disso, a pauta de exportações era bastante diversificada, incluindo automóveis, aviões e compressores. Segundo Penna Filho (2001), além de o comércio entre os dois países crescer continuamente, a pauta bilateral sofreu alterações qualitativas nas últimas décadas. Ficou no passado a característica de um intercâmbio de produtos primários. O entrosamento é grande, particularmente, no setor automobilístico. Em 2001, a venda de aviões modelo ERJ-135 da Embraer para a companhia sul-africana South Africa Airlink, em um negócio de US\$ 1 bilhão, era outro forte indicativo das grandes possibilidades comerciais do Brasil na África do Sul (PENNA FILHO, 2001, p. 69-88).

As vendas para Angola também apresentaram uma pauta positiva. $\mathrm{O}$ equivalente a 80,96\% dos produtos vendidos, entre 1997 e 2002 eram manufaturados; perto de um terço do valor comercializado consistia em commodities. Na pauta de mercadorias, estavam veículos e aviões, mas esses itens correspondiam a menos de $3 \%$ do total vendido para cada um dos itens. As vendas para os demais países africanos refletiram a característica geral apontada no comércio com o continente como um todo: grande participação de commodities, apesar de muitas delas serem classificadas como produtos manufaturados, a exemplo de outros açúcares de cana, beterraba, sacarose quimicamente pura. Das mercadorias comercializadas para Argélia, Egito, Marrocos e Nigéria, o proporcional de commodities passa de dois terços das exportações.

África do Sul, Nigéria e Argélia, importantes mercados de destino de produtos brasileiros, também apareceram no topo da lista dos principais fornecedores, dos quais o país mais importou mercadoria, entre 1995 e 2002. No período, o Marrocos esteve ainda entre os cinco principais países importadores do Brasil, mas com uma participação proporcionalmente pequena, de apenas um dígito. 
Tabela 18: Os cinco principais mercados fornecedores do Brasil na África entre 1995 e 2002. Valores de importação em dólar (US\$ FOB)

\begin{tabular}{|l|r|c|l|c|c|}
\hline País & \multicolumn{1}{|c|}{$\mathbf{1 9 9 5}$} & Part. & País & $\mathbf{1 9 9 6}$ & Part. \\
\hline África do Sul & 336.941 .472 & $29 \%$ & Argélia & 668.430 .006 & $40 \%$ \\
\hline Nigéria & 283.745 .308 & $24 \%$ & África do Sul & 418.411 .517 & $25 \%$ \\
\hline Argélia & 236.591 .570 & $20 \%$ & Nigéria & 254.910 .601 & $15 \%$ \\
\hline Guiné & 53.284 .537 & $5 \%$ & Angola & 140.272 .544 & $8 \%$ \\
\hline Marrocos & 49.029 .220 & $4 \%$ & Marrocos & 42.326 .065 & $3 \%$ \\
\hline
\end{tabular}

\begin{tabular}{|l|r|c|l|c|c|}
\hline País & $\mathbf{1 9 9 7}$ & Part. & País & $\mathbf{1 9 9 8}$ & Part. \\
\hline Argélia & 767.653 .833 & $38 \%$ & Argélia & 623.639 .913 & $34 \%$ \\
\hline Nigéria & 520.281 .896 & $26 \%$ & Nigéria & 611.505 .673 & $34 \%$ \\
\hline África do Sul & 351.396 .860 & $18 \%$ & África do Sul & 287.358 .946 & $16 \%$ \\
\hline Benin & 86.209 .944 & $4 \%$ & Benin & 81.410 .590 & $4 \%$ \\
\hline Marrocos & 50.181 .968 & $3 \%$ & Marrocos & 75.699 .645 & $4 \%$ \\
\hline
\end{tabular}

\begin{tabular}{|l|r|c|l|r|c|}
\hline País & \multicolumn{1}{|c|}{ 1999 } & Part. & País & 2000 & Part. \\
\hline Argélia & 987.738 .002 & $44 \%$ & Argélia & 1.508 .469 .854 & $52 \%$ \\
\hline Nigéria & 738.612 .506 & $33 \%$ & Nigéria & 733.604 .876 & $25 \%$ \\
\hline África do Sul & 172.389 .241 & $8 \%$ & África do Sul & 227.762 .569 & $8 \%$ \\
\hline Costa do Marfim & 66.853 .781 & $3 \%$ & Marrocos & 82.736 .821 & $3 \%$ \\
\hline Marrocos & 58.561 .209 & $3 \%$ & Congo & 74.008 .276 & $3 \%$ \\
\hline
\end{tabular}

\begin{tabular}{|l|r|r|l|r|c|}
\hline País & \multicolumn{1}{|c|}{$\mathbf{2 0 0 1}$} & Part. & País & 2002 & Part. \\
\hline Nigéria & 1.376 .173 .566 & $41 \%$ & Nigéria & 1.094 .550 .433 & $41 \%$ \\
\hline Argélia & 1.097 .793 .670 & $33 \%$ & Argélia & 998.926 .068 & $37 \%$ \\
\hline África do Sul & 285.973 .114 & $9 \%$ & África do Sul & 181.667 .025 & $7 \%$ \\
\hline Angola & 174.837 .212 & $5 \%$ & Marrocos & 146.490 .261 & $5 \%$ \\
\hline Marrocos & 97.323 .006 & $3 \%$ & Gabão & 54.593 .871 & $2 \%$ \\
\hline
\end{tabular}

Fonte: Elaboração própria a partir de dados do Aliceweb (BRASIL, 2014a).

Ao levar em conta as exportações e importações dos principais parceiros comerciais do Brasil no continente africano, foi possível identificar os países com os quais o Brasil tem a balança comercial mais favorável. Para a África do Sul, os resultados negativos registrados de 1995 a 1998 se tornaram superávits crescentes para o Brasil até 2002. Nos anos FHC, a conta foi sempre superavitária a este lado do Atlântico no comércio com Egito e Marrocos. No caso de Angola, há certa irregularidade, uma balança oscilando entre superávits e déficits. As trocas comerciais com os mercados da Argélia e Nigéria registraram os maiores déficits. 
Gráfico 13: A balança comercial do Brasil com os principais compradores de mercadorias na África: África do Sul, Angola, Argélia, Egito, Marrocos e Nigéria (1995-2002)

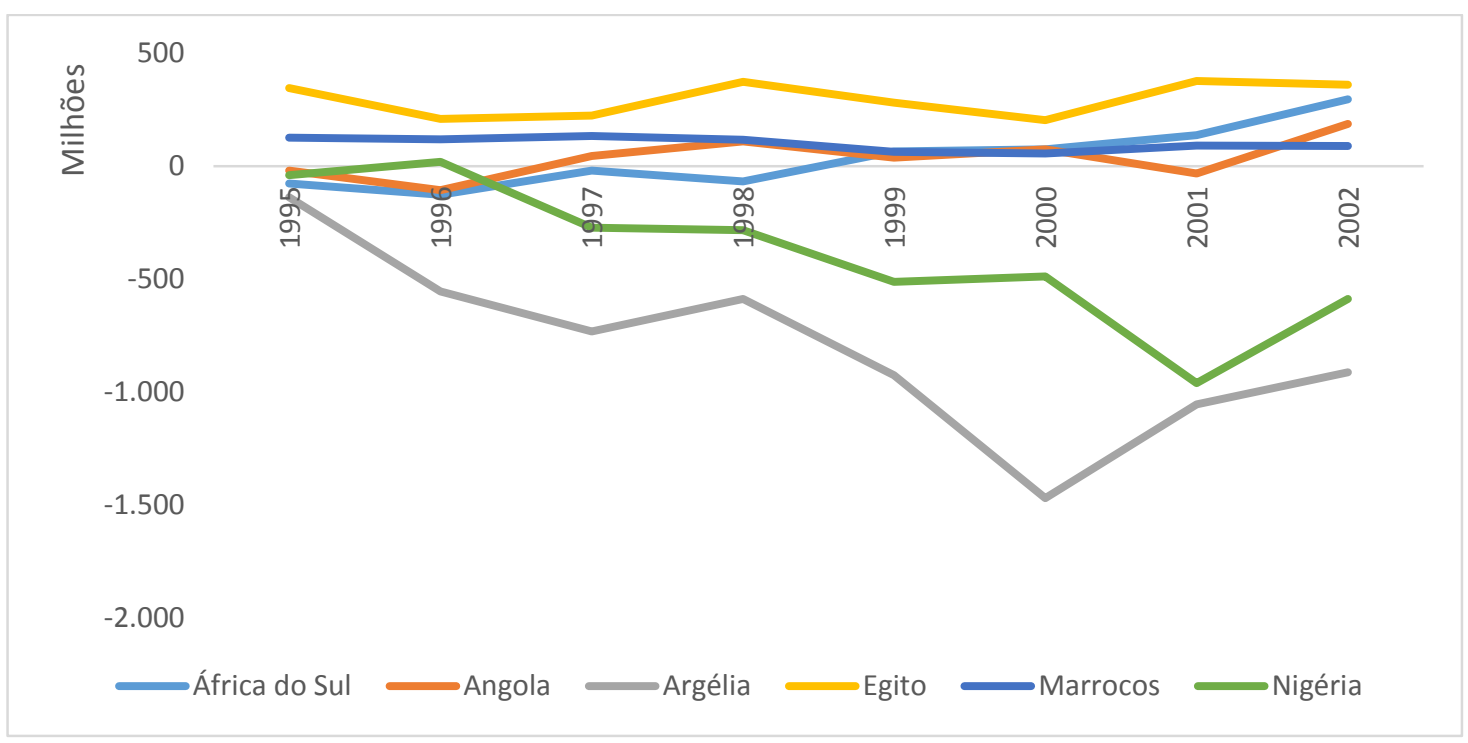

Fonte: Elaboração própria a partir de dados do Aliceweb (BRASIL, 2014a).

Para Santana (2003), as oportunidades de negócios no continente africano poderiam ser aproveitadas com mais agressividade empresarial. Não existe uma correspondente contrapartida de exportações brasileiras com os países de onde o Brasil importa valores elevados de mercadorias. Nesse caso, estão incluídos a Argélia, o Congo Brazzaville e a Costa do Marfim, de onde o Brasil importa uma elevada quantidade de produtos, mas para os quais não exporta em valor proporcional.

A Argélia, um dos países mais ricos da África, importa cerca de $40 \%$ dos alimentos consumidos por sua população, além de veículos e bens de capital, itens que o Brasil poderia vender para lá. O Congo Brazzaville é uma economia fundamentada principalmente na agricultura de subsistência, com poucas indústrias manufatureiras e a quase totalidade dos produtos industrializados são importados da França e da Holanda. E a Costa do Marfim, país próspero do oeste africano em razão de sua produção agrícola e mineral, tem um volume de importações elevado, com predominância de mercadorias oriundas de França, Estados Unidos, Holanda, Gana, Itália e Burkina Faso (SANTANA, 2003, p. 535-536).

O perfil dos produtos importados da África, durante os anos FHC, eram parecidos com o das mercadorias exportadas. A concentração, no entanto, dos produtos básicos e a predominância de commodities foram ainda mais acentuadas. Perto da metade do total importado da África, 48,85\%, consistiram em produtos básicos e 46,01\% eram commodities. Apenas óleos brutos de petróleo totalizaram 40,34\% do valor de todas as compras, mercadoria 
vinda de: Nigéria (75,81\% do total), Argélia (14,80\%), Angola (3,49\%), Congo Brazzaville (2,76\%), Gabão (1,94\%), Líbia (0,49\%), Gana (0,39\%) e Egito (0,33\%).

Tabela 19: Os dez principais produtos importados da África pelo Brasil (1997-2002)

\begin{tabular}{|c|c|c|c|c|c|}
\hline & NCM & Descrição & Fator Agregado & US\$ & Part. \\
\hline 1 & 27090010 & $\begin{array}{c}\text { Óleos brutos de } \\
\text { petróleo }\end{array}$ & PRODUTOS BASICOS & 6.031.096.270 & $40,34 \%$ \\
\hline 2 & 27100019 & Outras naftas & $\begin{array}{c}\text { PRODUTOS } \\
\text { MANUFATURADOS }\end{array}$ & 3.548.718.777 & $23,73 \%$ \\
\hline 3 & 27100011 & $\begin{array}{l}\text { Naftas para } \\
\text { petroquímica }\end{array}$ & $\begin{array}{c}\text { PRODUTOS } \\
\text { MANUFATURADOS }\end{array}$ & 1.035.907.582 & $6,93 \%$ \\
\hline 4 & 27111210 & $\begin{array}{c}\text { Propano em bruto, } \\
\text { liquefeito }\end{array}$ & $\begin{array}{c}\text { PRODUTOS } \\
\text { MANUFATURADOS }\end{array}$ & 426.587 .676 & $2,85 \%$ \\
\hline 5 & 52010090 & $\begin{array}{c}\text { Outros tipos de algodão } \\
\text { não cardado nem } \\
\text { penteado }\end{array}$ & PRODUTOS BASICOS & 400.080 .479 & $2,68 \%$ \\
\hline 6 & 27111300 & Butanos liquefeitos & $\begin{array}{c}\text { PRODUTOS } \\
\text { MANUFATURADOS }\end{array}$ & 264.199 .240 & $1,77 \%$ \\
\hline 7 & 27111910 & $\begin{array}{c}\text { Gás liquefeito de } \\
\text { petróleo (glp) }\end{array}$ & $\begin{array}{c}\text { PRODUTOS } \\
\text { MANUFATURADOS }\end{array}$ & 222.936 .731 & $1,49 \%$ \\
\hline 8 & 52010020 & $\begin{array}{l}\text { Algodão não cardado } \\
\text { nem penteado, } \\
\text { simplesmente } \\
\text { debulhado }\end{array}$ & PRODUTOS BASICOS & 198.414 .255 & $1,33 \%$ \\
\hline 9 & 27101141 & $\begin{array}{c}\text { Naftas para } \\
\text { petroquímica }\end{array}$ & $\begin{array}{c}\text { PRODUTOS } \\
\text { MANUFATURADOS }\end{array}$ & 157.923 .183 & $1,06 \%$ \\
\hline 10 & 27101149 & Outras naftas & $\begin{array}{c}\text { PRODUTOS } \\
\text { MANUFATURADOS }\end{array}$ & 150.769 .510 & $1,01 \%$ \\
\hline
\end{tabular}

Fonte: Elaboração própria a partir de dados do Aliceweb (BRASIL, 2014a).

Gráfico 14: O perfil dos produtos importados da África (1997-2002)

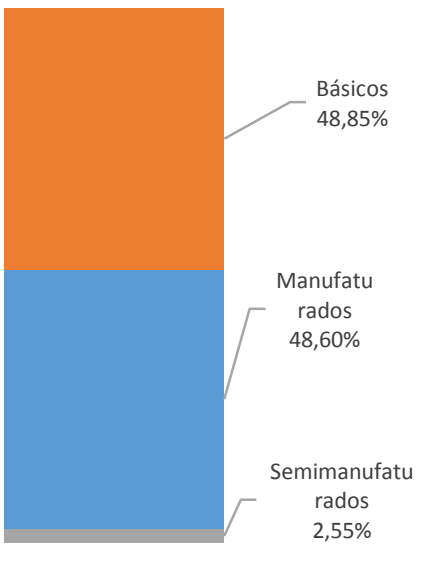

Fonte: Elaboração própria a partir de dados do Aliceweb (BRASIL, 2014a).

Os valores não somam $100 \%$ por causa das operações especiais. 
Gráfico 15: As principais commodities compradas da África (1997-2002)

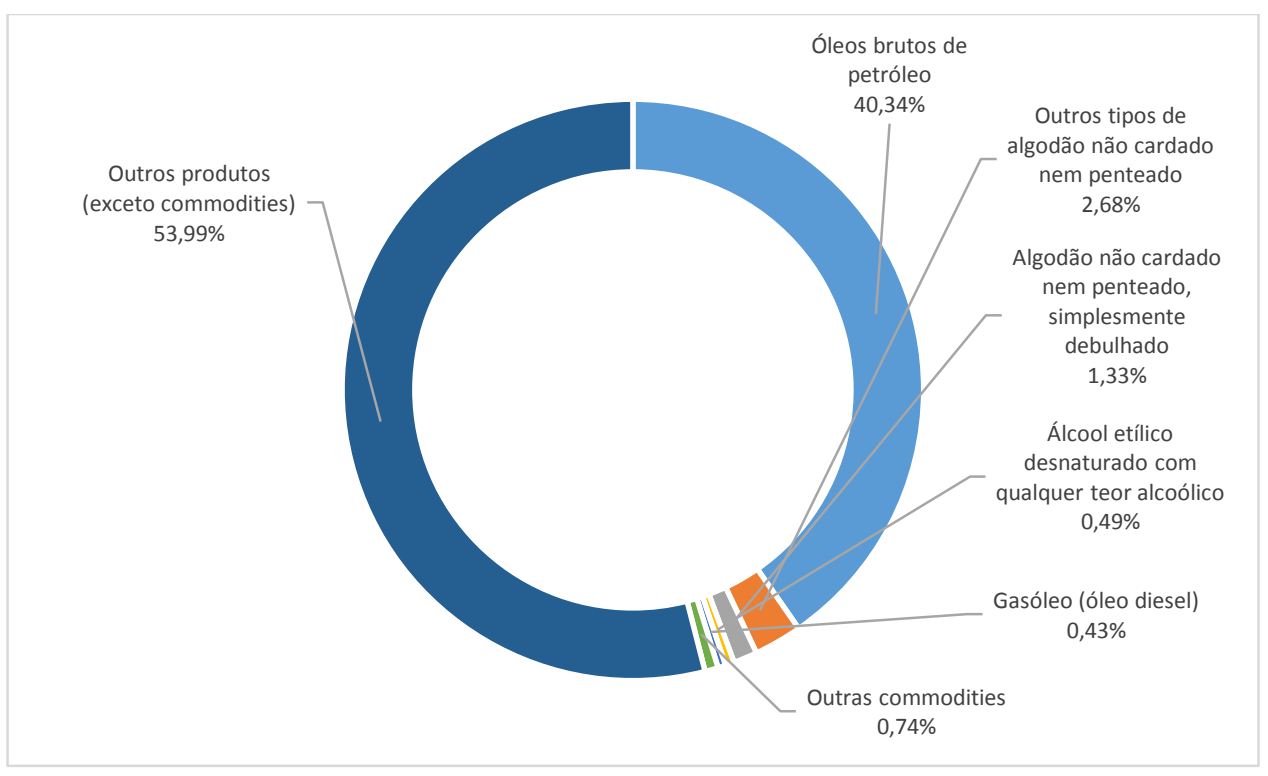

Fonte: Elaboração própria a partir de dados do Aliceweb (BRASIL, 2014a).

Nos anos FHC, o produto manufaturado mais comprado da África eram naftas, seguido por propano em bruto liquefeito, butanos liquefeitos e gás liquefeito de petróleo, todos derivados ou subprodutos do petróleo. Para avaliação do perfil das importações também foi considerado o período entre 1997 e 2002, em função da mudança da classificação dos produtos na balança comercial do Brasil com a adoção da Nomenclatura Comum do Mercosul (NCM).

Ademais, durante os anos de governo de Fernando Henrique, o Brasil começou a registrar déficits na balança comercial com a África. Entre os anos de 1989 e 1995, foram seis anos de superávit e apenas um, 1993, em que este comércio fechou com resultado negativo para o Brasil. A partir de 1996, o superávit se transformou em déficit e seguiu assim durante a maior parte do governo de Lula, com o agravante de que durante os anos de governo do Partido dos Trabalhadores, o valor do déficit comercial se acentuou consideravelmente. 
Gráfico 16: A balança comercial do Brasil com a África (1989-2002)

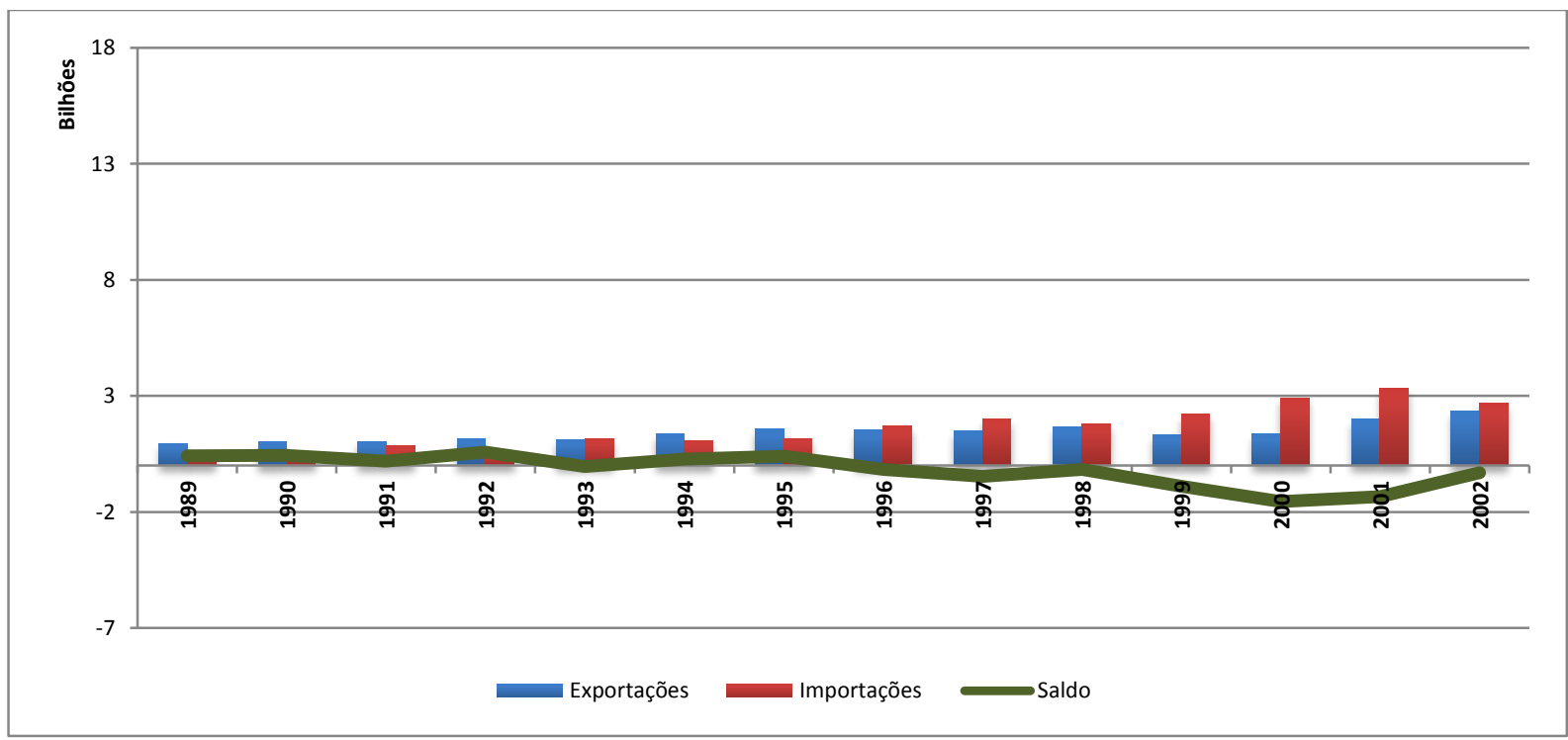

Fonte: Elaboração própria a partir de dados do Aliceweb (BRASIL, 2014a).

O resultado deficitário do comércio Brasil-África repetia o desempenho da balança comercial brasileira como um todo. Na avaliação de Heloísa C. Machado Silva (2005), a política comercial sofreu alterações desde quando Fernando Henrique assumiu a presidência, em 1995, amparado pela alta popularidade do Plano Real. A valorização da moeda brasileira, aliada a uma rápida liberalização tarifária, fez com que a balança comercial fechasse 1995 em déficit, depois de doze anos de superávit comercial. O saldo negativo se repetiu até o ano 2000, reflexo de dificuldades conjunturais e regionais do comércio exterior. No âmbito das dificuldades conjunturais, enquadram-se atritos no âmbito do Acordo Geral Sobre Tarifas Aduaneiras e Comércio (GATT) e da Organização Mundial do Comércio (OMC), quando, na maioria das vezes, o Brasil saiu prejudicado. No âmbito regional, as dificuldades diziam respeito às negociações para a criação da Área de Livre Comércio das Américas (Alca), aos subsídios agrícolas da União Europeia, às dificuldades no entendimento com a Argentina e ao contencioso entre a brasileira Embraer e a canadense Bombardier (SILVA, 2005, p.298).

Para Amado Cervo (2002), o baixo desempenho da balança comercial brasileira também refletia as escolhas de um governo liberal que transformou o comércio exterior em variável dependente da estabilidade monetária. Uma timidez sistêmica nacional, associada a fraquezas políticas e operacionais, reverteu a tendência histórica do comércio exterior brasileiro de gerar superávits (CERVO, 2002, p.16). Para Saraiva (2005), a diplomacia de Cardoso deixou de tratar o comércio exterior como instrumento estratégico de desenvolvimento. Rompendo a tradição de gerar superávits comerciais, o governo agravou a balança de pagamentos. A estratégia de 
abertura desenfreada foi um fracasso ante a vulnerabilidade externa, que se ampliou, reafirmada pelo aumento do abismo da dependência tecnológica, científica e empresarial que se cultivou, além da busca de capitais externos a altos juros internacionais como mecanismo de recomposição da crise do comércio externo (SARAIVA, 2005, p. 72).

No final do governo FHC, era frequente a análise de que o Brasil poderia aumentar o comércio com a África. Santana (2003) acredita que as relações comerciais entre o Brasil e o continente africano se concentravam em grande medida, nos países petrolíferos, como Líbia, Nigéria, Gabão, Argélia, Angola e Congo Brazzaville. A África do Sul despontava como um parceiro de elevado valor estratégico em função de sua posição geográfica e do nível de desenvolvimento industrial, elevado em comparação com outros países africanos (SANTANA, 2003, p. 550-551).

Também o mercado dos países africanos da CPLP foi apontado como potencial para a venda de mercadorias e serviços, como a construção civil e a agropecuária. A Comunidade, criada também com o intuito de promover o comércio, deixou frustrações em termos de intercâmbio comercial. A língua portuguesa comum e o interesse político do governo brasileiro em desenvolver maior cooperação representariam um grande atrativo para impulsionar um comércio de grandes potencialidades. Além disso, contribuiria para aumentar as trocas comerciais, o enfrentamento de questões como o desconhecimento sobre a qualidade dos produtos e serviços brasileiros pelos empresários africanos; e o fato de o setor privado brasileiro não estar familiarizado com as diferenças entre os diversos países africanos e, por isso, tenderia a julgar a África como um todo em função de aspectos negativos ressaltados pela imprensa (SANTANA, 2003, p. 550-551).

Saraiva (2004) argumenta que a promoção comercial do estado nacional é deficiente. Faltava ao Brasil capacitar profissionais no intuito de impulsionar o comércio de produtos nacionais. O conservadorismo do Itamaraty, embora muito positivo no que se refere aos grandes temas de interesse externo, não havia demonstrado capacidades operativa e cooperativa para as novas possibilidades comerciais. Para o autor, burocracia excessiva e centralismo, nesse setor, são nefastos; uma vez que o comércio opera em um espaço de tempo mais breve que o tempo da política internacional. A formação de quadros, mais ambientados com os novos desafios, necessitava ser pensada naquele momento. (SARAIVA, 2004, p. 152-159). 


\section{O COMÉRCIO EXTERIOR DO BRASIL COM A ÁFRICA NO GOVERNO LUIZ INÁCIO LULA DA SILVA (2003-2010)}

O presidente Luiz Inácio Lula da Silva herdou uma década de baixa densidade nas relações do Brasil para a África, quando o continente esteve fora do norte da política externa por ser considerado, pelos formuladores dessa política, como menos relevante à inserção internacional do país. Nos anos Lula, surgiu o propósito de renovar a política africana do Brasil (SARAIVA, 2002, p.5-10). O Executivo de Lula implementou uma evolução do entendimento do papel e da importância da África em relação às dificuldades do governo Cardoso. O escalão mais elevado do governo atuou como um contraponto à baixa apreciação da África por parte da mídia e de agentes sociais e econômicos brasileiros, cuja visão de tragédias e genocídios ganhavam a cor espetacular das telas televisivas, e enquanto as experiências de estabilização e crescimento econômico, assim como as iniciativas políticas de redução da pobreza e das doenças endêmicas, eram silenciadas. Na imprensa brasileira, a África chegava enviesada e embalada por caleidoscópio de discursos intermediários que apenas envergavam a vara para a percepção de um continente envolto em questões de discriminação racial e de preconceitos domésticos brasileiros (SARAIVA, 2008, p.87-91).

Os anos de governo de Lula foram responsáveis por uma retomada vigorosa da aproximação do Brasil com a África. Segundo Penna Filho (2013), é mais adequado falar em retomada porque, durante os dois governos do ex-presidente Cardoso, houve um certo retraimento da presença brasileira no continente africano, motivado principalmente, pela profunda crise que atingiu diversos países africanos e pelas prioridades dadas pela diplomacia de FHC a questões vinculadas aos processos de globalização e regionalização. O Brasil reaproximou-se da África em um momento muito mais favorável do que foi o da década de 1990. No fim do século XX, as transformações internas no continente africano tomaram forma, com a redução drástica das situações de conflito, a conquista da estabilidade política e a retomada do crescimento econômico. Aliada a esses fatores, a perspectiva da política externa de Lula, de enfatizar as relações Sul-Sul, era bastante distinta da de FHC. Ademais, o fenômeno novo do governo Lula na África foi o impressionante crescimento dos investimentos brasileiros no continente (PENNA FILHO, 2013, p. 10-11).

A cooperação com a África da política externa de FHC foi substituída pela solidariedade

com a África nos anos Lula. Nas relações com os países africanos, FHC limitava-se a proclamar uma bem intencionada política de cooperação, não imediatamente seguida de ações. O governo 
Lula, no entanto, proclamou a adoção de uma política de ativa solidariedade com a África, quase que como uma espécie de reconhecimento pelos séculos de tráfico, de escravidão e de exclusão interna dos afrodescendentes no Brasil, e prometeu passar à ação concreta (ALMEIDA, 2004, p. 11). Nos anos Lula, os países da África passaram a figurar como principais destinos da assistência técnica concedida pela Agência Brasileira de Cooperação $(\mathrm{ABC})$, em resposta a demandas provenientes das representações diplomáticas, ou a ofertas configuradas durante visitas presidenciais. A atuação do Brasil na África passou a ser instrumentalizada pelas agências especializadas do Estado, especialmente a Embrapa, na área de produção de alimentos; Fiocruz, no campo da saúde; e Senai, para a projetos de formação profissional (HIRST; LIMA; PINHEIRO, 2010, p.33).

O presidente Lula relançou a política africana do Brasil, que voltou a desempenhar um papel político e econômico no continente. O governo encerrou, em parte, o discurso culturalista que havia permeado historicamente as inflexões do país para substitui-lo pelo da dívida histórica do Brasil com a África. O Brasil tem a maior população afrodescendente fora da África; dessa forma, laços históricos, demográficos e culturais estariam na base da busca de um relacionamento mais próximo, segundo o então ministro de relações exteriores Celso Amorim (2010). Os países africanos de língua portuguesa foram aqueles com os quais o Brasil cultivou relações mais duradouras, sólidas e diversificadas; o estreitamento de relações não se deu, no entanto, apenas com esses países (AMORIM, 2010, p.233-234). Para Saraiva (2012), os dois mandatos ajudaram a construir uma política de mais permanência e continuidade na fronteira atlântica do Brasil (SARAIVA, 2012, p. 97).

Ainda no primeiro ano de mandato, Lula oficializou a criação do Fórum de Diálogo Índia, Brasil e África do Sul (IBAS), uma iniciativa de cooperação Sul-Sul, com a missão de fortalecer a capacidade dos três países em negociações internacionais, lutar pela reforma das Nações Unidas e promover a cooperação técnica em diversas áreas. A aliança entre Índia, Brasil e África do Sul tinha sido estabelecida inicialmente para enfrentar uma questão de propriedade intelectual na área farmacêutica, ainda durante os anos de FHC. Brasil e África do Sul levaram adiante o contencioso das patentes contra os Estados Unidos, defendendo a possibilidade de os países incentivarem a produção interna de remédios contra o HIV a custos menores. O esforço incorporou a Índia, que dentro dos benefícios da "fase de transição" do Acordo Trips, produzia e vendia medicamentos similares aos de indústrias norte-americanas a custos menores. Os governos brasileiro e sul-africano puderam então passar a comprar o coquetel anti-HIV da Índia (GOMES SARAIVA, 2007, p.55-57). 
O interesse pela comunidade africana esteve também associado a motivações políticas do Brasil no tabuleiro mundial. A aspiração por um lugar permanente no Conselho de Segurança das Nações Unidas reforçou o diálogo com os países africanos e levou a diplomacia brasileira a buscar explicitamente apoio à candidatura do país (HIRST; LIMA; PINHEIRO, 2010, p.33). O movimento de ampliação de parcerias era parte da nova dinâmica da política externa brasileira que visava à construção de alianças preferenciais com parceiros no âmbito das relações Sul-Sul (RIBEIRO, 2010, p. 75-76).

Outra iniciativa patrocinada pela diplomacia Lula foi a criação do grupo político do BRIC, congregando Brasil, Rússia, Índia e China, e mais tarde, convergindo para os BRICS, com a entrada da África do Sul. A parceria era parte da ênfase explícita da política econômica externa brasileira, que, desde 2003, passou a fortalecer as relações políticas e econômicas do Brasil com outras grandes economias em desenvolvimento (ABREU, 2007, p. 170).

Nos seus dois mandatos, o presidente Lula empreendeu uma ofensiva diplomática em direção à África (COSTA; VEIGA, 2011, p. 17-18). As viagens oficiais do Executivo visavam à implementação e renovação de projetos bilaterais e ao estabelecimento de acordos de cooperação de âmbito multilateral, pelos quais se deduz a possibilidade de abertura e/ou de ampliação de novos mercados (RIBEIRO, 2007, p. 175-225). Para Ribeiro, desde o pós-Guerra Fria, a política africana do Brasil se caracterizou por um processo de intensidade variável, que reflete os ajustes de agenda (adjustment changes) promovidos pelos governos brasileiros. $\mathrm{O}$ argumento dele é o de que, entre os governos Sarney e Lula, a política externa não chegou a registrar mudanças drásticas de agenda no que se refere às relações com o continente africano, mas de intensidade. Dessa forma, a política se ajustou às variações registradas no plano internacional e na própria agenda diplomática brasileira (RIBEIRO, 2007, p. 222-225).

Em oito anos de mandato, Lula visitou vinte e dois países africanos, constantemente acompanhado por uma comitiva de empresários brasileiros. Em alguns países, esteve mais de uma vez, como na África do Sul, que visitou quatro vezes. Para Moçambique, foram três viagens; para Angola, duas. Algumas escalas renderam críticas sobre os critérios de escolha dos parceiros, como na ocasião do encontro de Lula com Obiang Nguema, de Guiné Equatorial, então com trinta e um anos de governo iniciado por um golpe de Estado. Antes da reunião, o ministro Amorim classificou as referências da mídia às violações contra direitos humanos cometidas por Nguema como pregações moralistas (SZKLARZ, 2010, p.20). 
Tabela 20: Viagens do presidente Luiz Inácio Lula da Silva à África

\begin{tabular}{|c|c|}
\hline Data & Evento \\
\hline 02 a 08.11 .2003 & $\begin{array}{l}\text { São Tomé e Príncipe, São Tomé: Visita oficial } \\
\text { Angola, Luanda: Visita oficial } \\
\text { Moçambique, Maputo: Visita oficial } \\
\text { Namíbia, Windhoek: Visita de Estado } \\
\text { África do Sul, Pretória: Visita oficial }\end{array}$ \\
\hline 26 a 29.07 .2004 & $\begin{array}{l}\text { V Conferência dos Chefes de Estado e de Governo dos Países de Língua } \\
\text { Portuguesa, em São Tomé e Príncipe } \\
\text { Encontro com o Presidente do Gabão, Omar Bongo Ondimba, em } \\
\text { Libreville. Assinatura de Atos. } \\
\text { Encontro com o Presidente da República de Cabo Verde, Pedro Verona } \\
\text { Rodrigues Pires, na Ilha do Sal. Seminário Empresarial com a participação } \\
\text { do primeiro-ministro de Cabo Verde, José Maria Pereira Neves. Sessão } \\
\text { solene na Assembleia Nacional de Cabo Verde por ocasião da Visita de } \\
\text { Estado do senhor Presidente da República. Cerimônia de descerramento de } \\
\text { placa alusiva à doação do Brasil de computadores, por ocasião da Visita de } \\
\text { Estado a Cabo Verde. Assinatura de Atos. }\end{array}$ \\
\hline 10 e 14.04 .2005 & $\begin{array}{l}\text { Reunião de trabalho com o presidente de Camarões, senhor Paul Biya, em } \\
\text { Iaundê, Camarões, e assinatura de atos. } \\
\text { Reunião reservada com o presidente da Nigéria, Olusegun Obasanjo, em } \\
\text { Abuja, Nigéria. Audiência com o secretário-executivo da Comunidade } \\
\text { Econômica dos Estados da África Ocidental (Ecowas), Mohamed Ibn } \\
\text { Chambas, assinatura de atos. } \\
\text { Encontro com o senhor John Agyekum Kufuor, presidente da República de } \\
\text { Gana, em Acra. Assinatura de Atos. Cerimônia de inauguração da Câmara } \\
\text { de Comércio Brasil-Gana. } \\
\text { Reunião privada com o presidente da Guiné-Bissau, Henrique Rosa, em } \\
\text { Bissau. Reunião com o primeiro-ministro da Guiné-Bissau, Carlos Gomes } \\
\text { Júnior. } \\
\text { Reunião privada com o presidente do Senegal, senhor Abdoulaye Wade, em } \\
\text { Dacar. }\end{array}$ \\
\hline 07 a 12.02 .2006 & $\begin{array}{l}\text { Encontro privado dos Chefes de Estado em Argel, Argélia. Assinatura de } \\
\text { Atos. Audiência concedida ao senhor Ahmed Ouyahia, chefe do Governo } \\
\text { Encontro privado com o senhor Mathieu Kerekou, presidente da República } \\
\text { do Benin, em Cotonou. } \\
\text { Encontro privado com o presidente da República de Botsuana, Festus } \\
\text { Mogae, em Gaborone. Encontro com o secretário-executivo da Comunidade } \\
\text { para o Desenvolvimento da África Austral, SADC, Tomaz Salomão. }\end{array}$ \\
\hline
\end{tabular}




\begin{tabular}{|c|c|}
\hline & $\begin{array}{l}\text { Seminário Empresarial Brasil-Botsuana: Oportunidades de Comércio e } \\
\text { Investimentos. Assinatura de Atos. } \\
\text { Sessão Especial da Cúpula da Governança Progressista, em Johanesburgo, } \\
\text { África do Sul. }\end{array}$ \\
\hline 28 a 30.11 .2006 & $\begin{array}{l}\text { I Cúpula África-América do Sul, em Abuja, Nigéria. Encontro com o } \\
\text { presidente do Togo, Faure Gnassingbé. Encontro com o presidente de Gana, } \\
\text { John Agyekum Kufuor. Encontro com o presidente da Argélia, Abdelaziz } \\
\text { Bouteflika. Encontro com o presidente de Moçambique, Armando Emílio } \\
\text { Guebuza. Café da manhã com o presidente da Líbia, Muammar Al- } \\
\text { Khaddafi. }\end{array}$ \\
\hline 15 a 18.10 .2007 & $\begin{array}{l}\text { Encontro com o presidente de Burkina Faso, Blaise Compaoré, } \\
\text { Ouagadougou. Encontro Empresarial. Colóquio "Democracia e } \\
\text { Desenvolvimento na África". Assinatura de Atos. Abertura da Semana do } \\
\text { Cinema Brasileiro em Ouagadougou. } \\
\text { Cerimônia de recepção do presidente Luiz Inácio Lula da Silva pelo } \\
\text { presidente da República do Congo, Denis Sassou Nguesso, em Brazzaville. } \\
\text { Assinatura de Atos. } \\
\text { Reunião de Cúpula do IBAS, em Johanesburgo, África do Sul. Assinatura } \\
\text { de Atos. Encontro Bilateral com o presidente da África do Sul, Thabo Mbeki } \\
\text { Reunião com José Eduardo dos Santos, presidente de Angola, em Luanda. } \\
\text { Assinatura de Atos. }\end{array}$ \\
\hline 19 a 21.04 .2008 & $\begin{array}{l}\text { Encontro com o presidente da República de Gana, John Agyekum Kufour, } \\
\text { em Acra. Assinatura de atos. Cerimônia de descerramento de placa alusiva } \\
\text { à visita às instalações do escritório regional da Embrapa na África. } \\
\text { Cerimônia de abertura da XII Reunião da Conferência das Nações Unidas } \\
\text { sobre Comércio e Desenvolvimento, Unctad. }\end{array}$ \\
\hline 16 e 17.10 .2008 & $\begin{array}{l}\text { Encontro com representantes de quatro empresas brasileiras que operam em } \\
\text { Moçambique. Encontro privado com o presidente da República de } \\
\text { Moçambique, Armando Guebuzae, em Maputo. Assinatura de atos. Sessão } \\
\text { de encerramento do encontro empresarial. Anúncio de entrega de unidade } \\
\text { móvel do Sesi (Cozinha Moçambique) para o governo de Moçambique. } \\
\text { Cerimônia de inauguração de instalações da Fundação Oswaldo Cruz } \\
\text { (Fiocruz), em Maputo. }\end{array}$ \\
\hline 30.06 a 01.07 .2009 & XIII Assembleia da União Africana, em Sirte, na Líbia. \\
\hline 03.07 a 09.07.2010 & $\begin{array}{l}\text { Sessão de abertura da Cúpula Brasil - Comunidade Econômica dos Estados } \\
\text { da África Ocidental, Cedeao, na Ilha do Sal, em Cabo Verde. Encontro com } \\
\text { o presidente de Cabo Verde, Pedro Pires. Encontro com o primeiro-ministro } \\
\text { de Cabo Verde, José Brito. }\end{array}$ \\
\hline
\end{tabular}




\begin{tabular}{|c|c|}
\hline & $\begin{array}{l}\text { Encontro privado com o presidente da Guiné Equatorial, Obiang Nguema } \\
\text { Mbasogo, em Malabo. Assinatura de atos. } \\
\text { Encontro privado com o presidente do Quênia, Mwai Kibaki, em Nairóbi. } \\
\text { Assinatura de atos. Sessão de encerramento do Seminário Empresarial } \\
\text { Brasil-Quênia. } \\
\text { Cerimônia de abertura do Encontro Empresarial Brasil-Tanzânia, em Dar es } \\
\text { Salaam. Reunião privada com o presidente da Tanzânia, Jakaya Mrisho } \\
\text { Kikwete. Assinatura de atos. } \\
\text { Encontro privado com o presidente da Zâmbia, Rupiah Bwezani Banda, em } \\
\text { Lusaca. Assinatura de atos. Cerimônia de encerramento do Seminário } \\
\text { Empresarial Brasil-Zâmbia } \\
\text { Cerimônia de início da jornada para a Copa do Mundo da Fifa Brasil 2014, } \\
\text { em Pretória. Encontro privado com o presidente da África do Sul, Jacob } \\
\text { Zuma. Assinatura de atos. Encerramento do Fórum Empresarial Brasil- } \\
\text { África do Sul. }\end{array}$ \\
\hline 09.11 a 10.11 .2010 & $\begin{array}{l}\text { Visita às instalações do Instituto Nacional de Educação a Distância (INED), } \\
\text { em Moçambique. Aula inaugural por ocasião da instalação do Polo da } \\
\text { Universidade Aberta do Brasil, no INED. Encontro com empresários } \\
\text { brasileiros que atuam em Moçambique. Encontro com o presidente de } \\
\text { Moçambique, Armando Guebuza. Assinatura de atos. Visita às instalações } \\
\text { da futura fábrica de antirretrovirais. }\end{array}$ \\
\hline
\end{tabular}

Fonte: Biblioteca da Presidência da República (2015).

Adicionalmente, a prioridade política atribuída ao continente africano pela política externa brasileira resultou no aumento de embaixadas do Brasil na África, cujo número mais do que dobrou no governo Lula, alcançando o total de 37 de 54 países, em 2011 (SARAIVA, 2012, p. 13). E, mesmo com as dificuldades financeiras da maioria dos africanos, 13 países do continente abriram representações permanentes em Brasília desde 2003, o que deixou a capital federal entre as principais do mundo em número de embaixadas africanas, com 29 representações (AMORIM, 2010, p.234). Para Saraiva (2012), a abertura das embaixadas brasileiras no continente vizinho do Atlântico evidenciou, para o mundo, que o Brasil voltou à África (SARAIVA, 2012, p; 13). Uma das críticas feitas a abertura dos postos davam conta de que a maioria das embaixadas abertas não tinha recursos suficientes para fazer promoção comercial e cultural no continente africano (SZKLARZ, 2010, p. 22).

Outro importante movimento da diplomacia Lula foi o reescalonamento de dívidas de três países africanos: Cabo Verde, Nigéria e Moçambique. A proporção da dívida perdoada de 
Moçambique correspondeu a $95 \%$ do total do débito originado em convênios de crédito para a exportação de bens e serviços, firmados desde 1978 (SUPLICY, 2004). Outros dois países, fora da África, foram beneficiados por resoluções de reescalonamento ou de renegociação de dívida com o Brasil no governo Lula; são eles Suriname e Bolívia. A leitura das resoluções aprovadas pelo Senado Federal sobre esses débitos mostra que, mais uma vez, como aconteceu durante o governo FHC, as dívidas dos países da África se referiam a negócios fechados no âmbito do comércio exterior.

Tabela 21: Descrição das dívidas da África com o Brasil negociadas pelo presidente Luiz Inácio Lula da Silva (2003-2010)

\begin{tabular}{|l|l|}
\hline \multicolumn{1}{|c|}{ País } & \multicolumn{1}{c|}{ Trechos retirados dos projetos de resoluções dos débitos } \\
\hline República de Moçambique & $\begin{array}{l}\text { Dívida proveniente de operações de financiamento a exportações realizadas ao } \\
\text { amparo do extinto Fundo de Financiamento à Exportação (FINEX). }\end{array}$ \\
\hline República Federal da Nigéria & $\begin{array}{l}\text { Dívida proveniente de operações de seguro de crédito à exportação, crédito } \\
\text { concedido nas décadas de } 1970 \text { e 1980, no âmbito do Fundo de Financiamento } \\
\text { à Exportação (FINEX). }\end{array}$ \\
\hline República de Cabo Verde & $\begin{array}{l}\text { Dívida oriunda de convênio de crédito firmado com recursos do extinto Fundo } \\
\text { de Financiamento às Exportações (FINEX). }\end{array}$ \\
\hline
\end{tabular}

Fonte: Elaboração própria a partir da leitura dos pareceres apresentados e disponíveis no site do Senado Federal. As duas outras proposições apresentadas pelo presidente Lula sobre negociação de dívida se referiam a pagamentos do Suriname e a uma autorização para a União aceitar dação de imóvel da Bolívia como parte do pagamento dos juros da dívida externa daquele país.

O argumento do governo brasileiro consistia na defesa de que os acordos possibilitavam reaver parte dos recursos considerados de difícil recuperação e contribuiriam com os esforços da comunidade internacional na renegociação ou no perdão de dívidas dos países pobres altamente endividados. O intuito do acordo seria, portanto, o de dar condições a esses países de retomar à trajetória de desenvolvimento e combate à pobreza. Mais do que isso, a renegociação permitiria a abertura de novas possibilidades para um novo impulso nas relações econômicas e comerciais entre Brasil e os países africanos, quando regularizado o relacionamento financeiro bilateral (BRASIL, 2013b). 
Tabela 22: Descrição de valores de dívida, perdão e reescalomento de dívidas de países da África com o Brasil / Luiz Inácio Lula da Silva (2003-2010)

\begin{tabular}{|l|r|r|r|r|}
\hline \multicolumn{1}{|c|}{ País } & $\begin{array}{c}\text { Total da dívida } \\
\text { (US\$) }\end{array}$ & $\begin{array}{c}\text { Perdão/Remissão } \\
(\%)\end{array}$ & $\begin{array}{c}\text { Dívida } \\
\text { Perdoada } \\
\text { (US\$) }\end{array}$ & $\begin{array}{c}\text { Valor reescalonado } \\
\text { (US\$) }\end{array}$ \\
\hline República de Moçambique & $331,686,015.65$ & $95 \%$ & $315,101,714.87$ & $16,584,300.78$ \\
\hline República Federal da Nigéria & $151,953,792.35$ & $56 \%$ & $84,660,006.35$ & $67,293,786.00$ \\
\hline República de Cabo Verde & $3,895,163.33$ & $31 \%$ & $1,197,962.40$ & $2,697,200.93$ \\
\hline
\end{tabular}

Fonte: Elaboração própria a partir da leitura dos pareceres apresentados e disponíveis no site do Senado Federal.

A política de maior aproximação com a África iniciada no governo Lula pareceu indicar uma bem sucedida política diplomática com o resultado da eleição do brasileiro Roberto Azevêdo para a direção-geral da Organização Mundial do Comércio, em 2013. O apoio maciço dos países africanos foi considerado decisivo para que o brasileiro saísse vitorioso da disputa (ALENCASTRO, 2013).

Tabela 23: O comércio entre o Brasil e a África (1995-2010)

\begin{tabular}{ccccc}
\hline & Exportação & Importação & Saldo & Corrente de Comércio \\
\hline Ano & US\$ FOB & US\$ FOB & US\$ FOB & US\$ FOB \\
\hline 1995 & 1.585 .821 .583 & 1.180 .637 .451 & 405.184 .132 & 2.766 .459 .034 \\
1996 & 1.527 .022 .348 & 1.690 .473 .093 & -163.450 .745 & 3.217 .495 .441 \\
1997 & 1.520 .000 .381 & 1.995 .198 .981 & -475.198 .600 & 3.515 .199 .362 \\
1998 & 1.651 .086 .046 & 1.819 .086 .788 & -168.000 .742 & 3.470 .172 .834 \\
1999 & 1.336 .476 .992 & 2.223 .842 .002 & -887.365 .010 & 3.560 .318 .994 \\
2000 & 1.347 .098 .183 & 2.907 .082 .676 & -1.559 .984 .493 & 4.254 .180 .859 \\
2001 & 1.989 .031 .346 & 3.330 .949 .802 & -1.341 .918 .456 & 5.319 .981 .148 \\
2002 & 2.363 .340 .654 & 2.675 .612 .821 & -312.272 .167 & 5.038 .953 .475 \\
2003 & 2.862 .003 .914 & 3.291 .174 .938 & -429.171 .024 & 6.153 .178 .852 \\
2004 & 4.247 .699 .268 & 6.183 .472 .779 & -1.935 .773 .511 & 10.431 .172 .047 \\
2005 & 5.981 .353 .507 & 6.656 .664 .579 & -675.311 .072 & 12.638 .018 .086 \\
2006 & 7.455 .879 .389 & 8.110 .811 .144 & -654.931 .755 & 15.566 .690 .533 \\
2007 & 8.578 .221 .741 & 11.346 .724 .972 & -2.768 .503 .231 & 19.924 .946 .713 \\
2008 & 10.169 .567 .120 & 15.761 .124 .122 & -5.591 .557 .002 & 25.930 .691 .242 \\
2009 & 8.692 .380 .077 & 8.465 .581 .857 & 226.798 .220 & 17.157 .961 .934 \\
2010 & 9.261 .599 .799 & 11.297 .251 .661 & -2.035 .651 .862 & 20.558 .851 .460 \\
\hline & & & & \\
\hline
\end{tabular}

Fonte: Elaboração própria a partir de dados do Aliceweb (BRASIL, 2014a). 
Para além das relações diplomáticas, o relacionamento comercial do Brasil com a África também cresceu a partir do governo Lula. A importância da África no comércio exterior do Brasil ganhou novo peso. A corrente de comércio chegou a alcançar US\$25,9 bilhões, em 2008, o melhor valor da série. A soma de exportações e importações era de US\$ 5,03 bilhões no último ano do governo FHC, o que mostra um crescimento de mais de $400 \%$ da corrente nos anos Lula. As importações e as exportações cresceram no período, com exceção de 2009, ano do ápice da crise financeira internacional. Apesar da queda, desde 2010, a corrente de comércio voltou ao patamar superior dos US\$ 20 bilhões e, afora as oscilações registradas nos anos seguintes, ainda se manteve acima desse nível. Os déficits da balança comercial, que começaram a ser registrados nos anos Cardoso, acentuaram-se no governo Lula porque as compras brasileiras na África cresceram percentualmente mais do que as vendas para o continente.

A participação da África na cesta de exportações brasileiras cresceu nos anos de governo do Partido dos Trabalhadores. O índice tomou uma curva ascendente e chegou a atingir 5,68\%, em 2009. Logo depois houve um recuo, mas sem que a participação voltasse ao nível anterior. O valor das exportações passou de US\$ 2,8 bilhões, em 2003, para US\$ 9,2 bilhões, em 2010. O avanço registrado foi de $223,61 \%$, bem acima do percentual de crescimento do total das exportações brasileiras, que avançaram $175 \%$ no período, em mais uma demonstração de que o Brasil passou a exportar mais para a África a partir do governo Lula. 
Gráfico 17: Participação das exportações para África no total das exportações do Brasil (19952010)

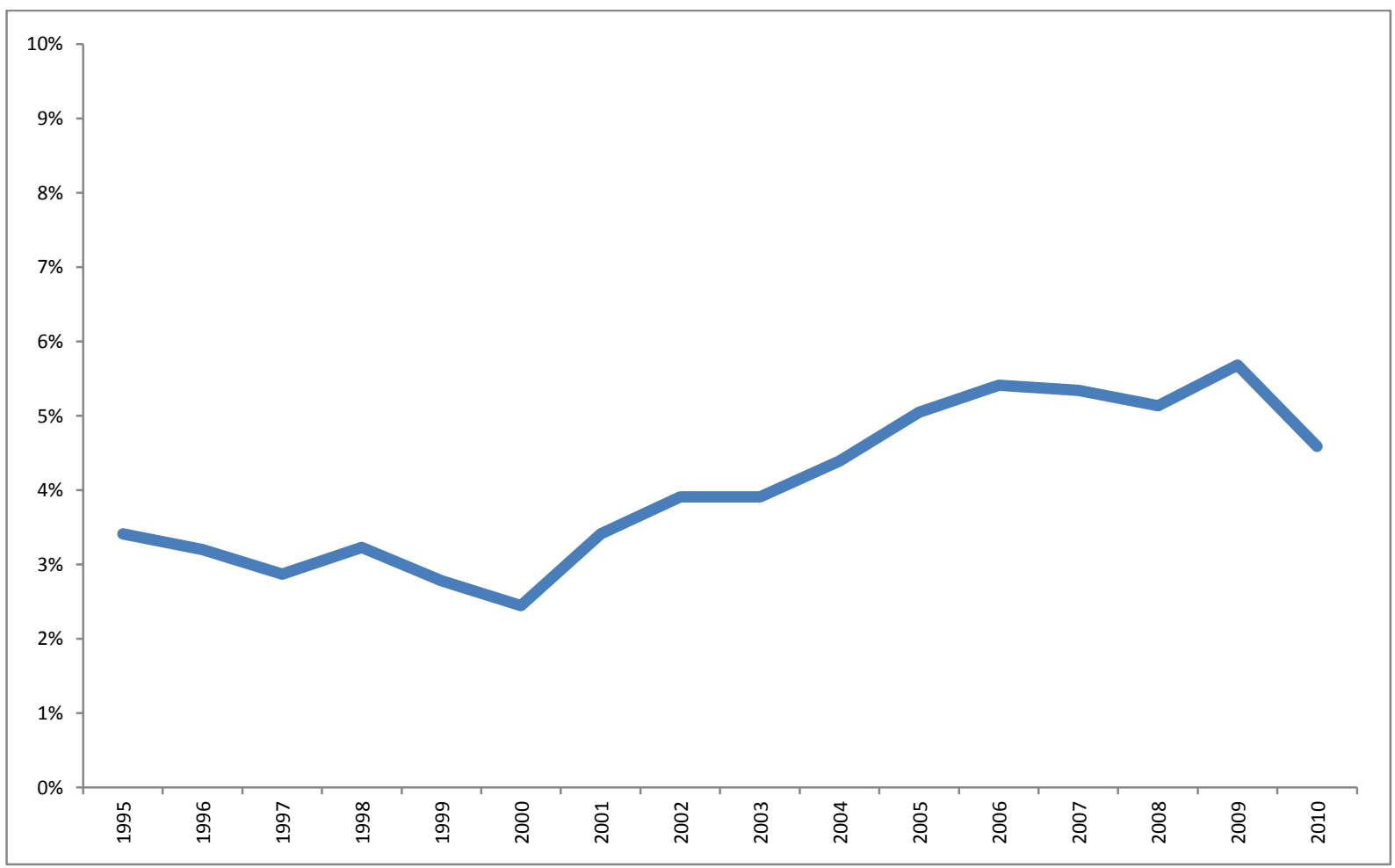

Fonte: Elaboração própria a partir de dados do Aliceweb (BRASIL, 2014a).

O aumento da exportação para a África nos anos de Lula na presidência se mostrou evidente neste estudo. Se durante os anos FHC, as vendas oscilaram pouco e mostravam certa estabilidade; no governo Lula no poder, as exportações cresceram significativamente e em um ritmo acelerado. As vendas para a África deram um salto entre 2003 e 2008, o crescimento foi interrompido apenas em 2009, o ponto mais crítico da crise financeira mundial. Depois disso, o valor voltou a crescer e fechou em US\$ 9,26 bilhões, em 2010. 
Gráfico 18: Participação das importações feitas da África no total das importações do Brasil (1995-2010)

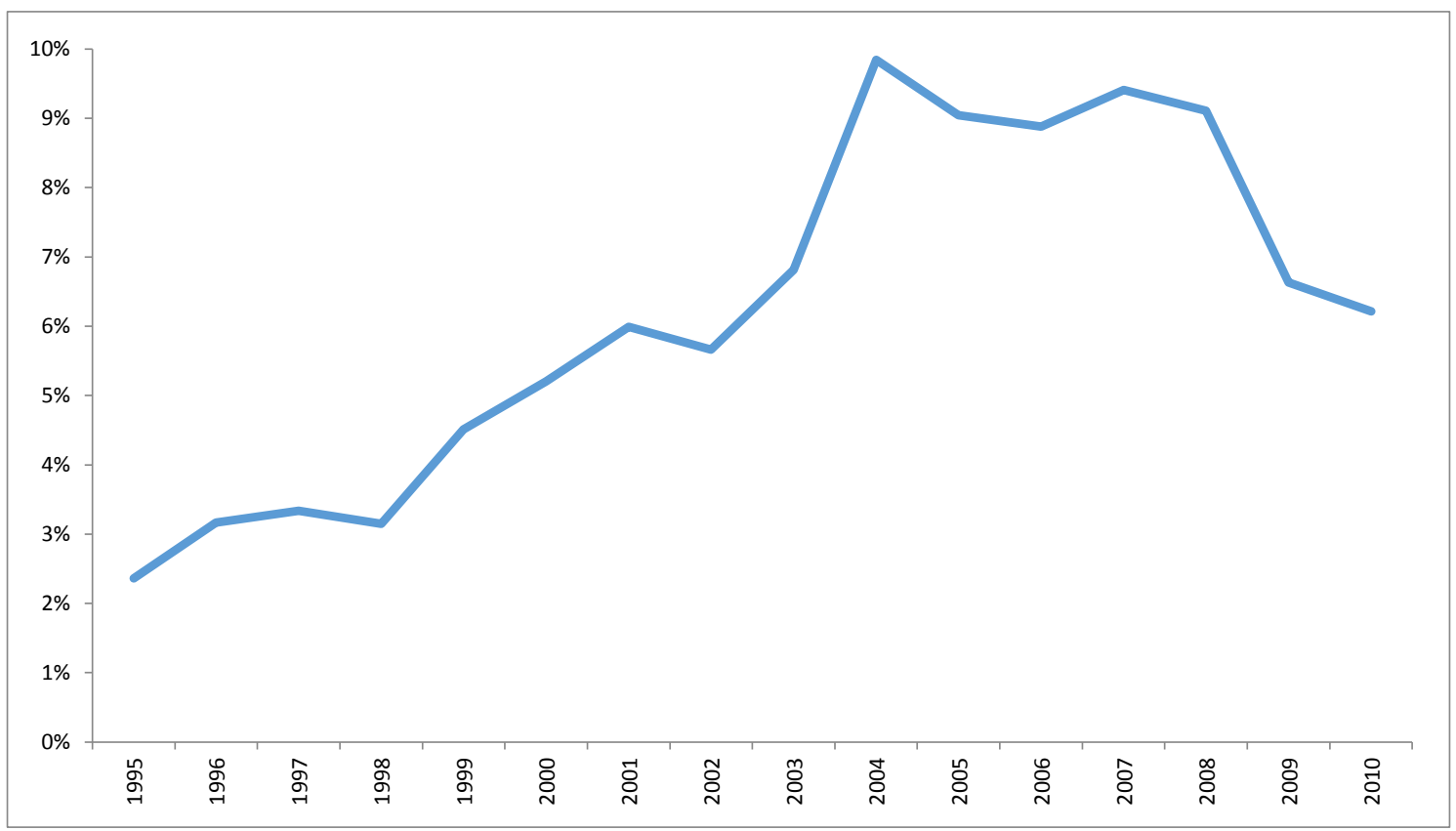

Fonte: Elaboração própria a partir de dados do Aliceweb (BRASIL, 2014a).

A participação da África nas importações brasileiras, que vinha em crescimento desde os anos FHC, tomou novo e vigoroso fôlego, chegando perto de atingir $10 \%$ do total das importações do Brasil, em 2004. O aumento do valor comercializado entre os parceiros, no entanto, veio acompanhado da piora no perfil das mercadorias vendidas. As exportações de produtos básicos, que cresceram no governo Cardoso, avançaram ainda mais e quase dobraram de percentual. Em 2003, 18,58\% do valor exportado pelo Brasil para a África eram de mercadorias classificadas como básicas. O percentual subiu para 31,58\%, em 2010. Houve redução principalmente do comércio de produtos manufaturados, que recuaram de $67,00 \%$ para 47,15\%. Apesar disso, os produtos com valor agregado, somados os manufaturados e semimanufaturados, ainda preservaram a maior parte das exportações do Brasil para o continente africano. 
Gráfico 19: Perfil das exportações do Brasil para a África (1995-2010)

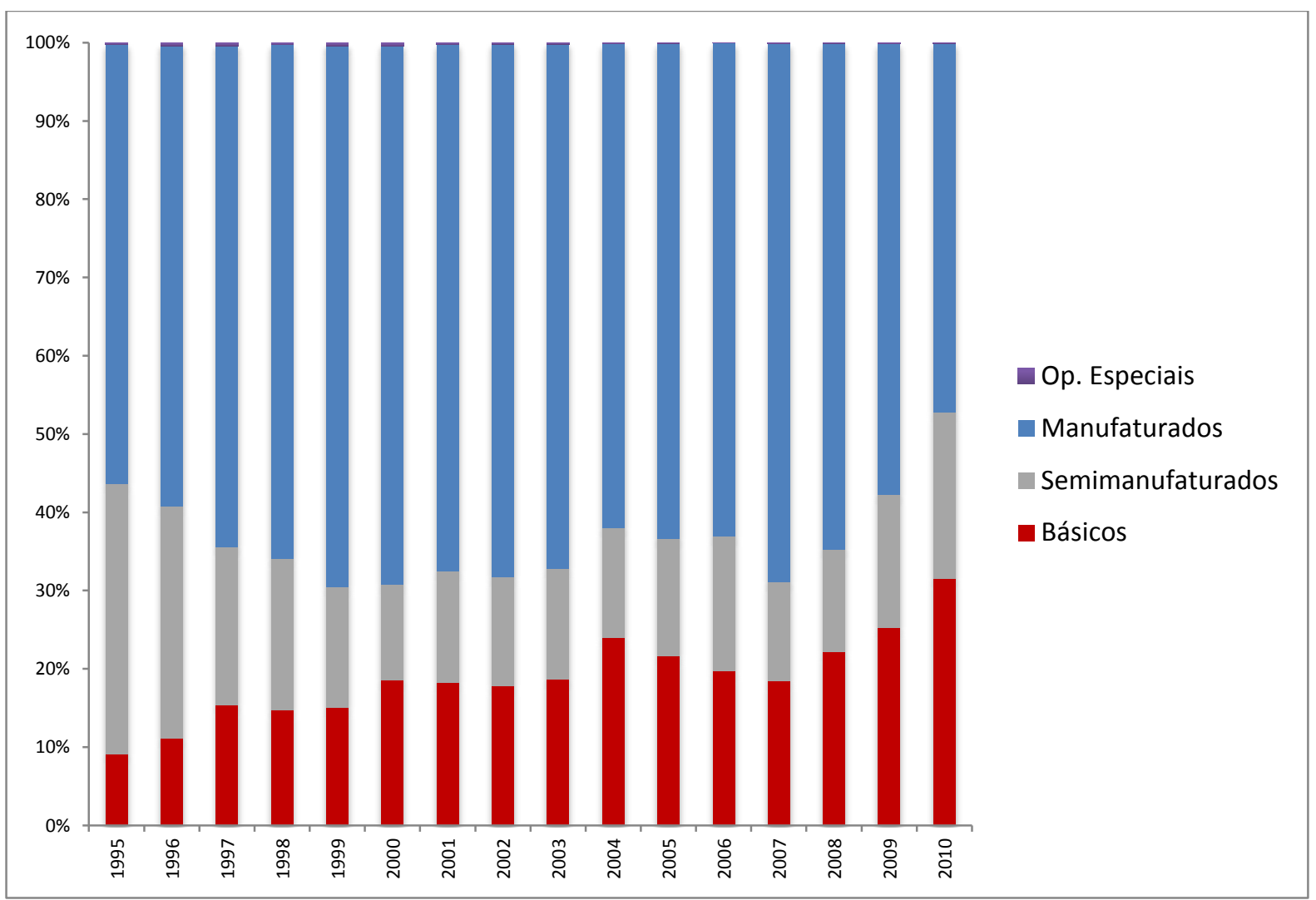

Fonte: Elaboração própria a partir de dados do Aliceweb (BRASIL, 2014a).

Tabela 24: Perfil das exportações do Brasil para a África (1995-2010)

\begin{tabular}{lcccc}
\hline & Básicos & Semimanufaturados & Manufaturados & Op. Especiais \\
\hline 1995 & $9,15 \%$ & $34,45 \%$ & $56,17 \%$ & $0,23 \%$ \\
1996 & $11,04 \%$ & $29,75 \%$ & $58,81 \%$ & $0,41 \%$ \\
1997 & $15,41 \%$ & $20,18 \%$ & $63,99 \%$ & $0,41 \%$ \\
1998 & $14,73 \%$ & $19,35 \%$ & $65,65 \%$ & $0,27 \%$ \\
1999 & $15,03 \%$ & $15,37 \%$ & $69,18 \%$ & $0,43 \%$ \\
2000 & $18,50 \%$ & $12,27 \%$ & $68,75 \%$ & $0,48 \%$ \\
2001 & $18,23 \%$ & $14,25 \%$ & $67,30 \%$ & $0,23 \%$ \\
2002 & $17,86 \%$ & $13,85 \%$ & $68,10 \%$ & $0,19 \%$ \\
2003 & $18,58 \%$ & $14,22 \%$ & $67,00 \%$ & $0,20 \%$ \\
2004 & $23,94 \%$ & $13,99 \%$ & $61,93 \%$ & $0,14 \%$ \\
2005 & $21,61 \%$ & $14,96 \%$ & $63,35 \%$ & $0,08 \%$ \\
2006 & $19,69 \%$ & $17,18 \%$ & $63,05 \%$ & $0,08 \%$ \\
2007 & $18,46 \%$ & $12,56 \%$ & $68,86 \%$ & $0,12 \%$ \\
2008 & $22,12 \%$ & $13,16 \%$ & $64,63 \%$ & $0,09 \%$ \\
2009 & $25,28 \%$ & $16,93 \%$ & $57,66 \%$ & $0,13 \%$ \\
2010 & $31,58 \%$ & $21,16 \%$ & $47,15 \%$ & $0,11 \%$ \\
\hline
\end{tabular}

Fonte: Elaboração própria a partir de dados do Aliceweb (BRASIL, 2014a).

A análise dos produtos vendidos durante os anos Lula para a África mostra uma forte concentração de açúcar de cana em bruto, e outros açúcares de cana, beterraba e sacarose 
quimicamente pura, os mesmos itens que lideravam a lista de produtos mais vendidos também no governo FHC. A proporção das vendas de gasolina, no entanto, cresceu substancialmente, passou de 1,29\% dos anos Cardoso para 5,91\% das vendas para o continente africano nos anos Lula. Anteriormente, o produto era o décimo mais vendido e, mais tarde, passou a ocupar o terceiro lugar. Também aumentou a participação do volume de carnes congeladas desossadas de bovino, que foi de $1,50 \%$ para $5,91 \%$. Houve redução no percentual de vendas de minério de ferro aglomerados e concentrados; e ainda de óleo de soja em bruto. O item veículos e automóveis para transporte caiu de posição, antes era o quinto mais vendido, passou a vigésimo quinto colocado.

Tabela 25: Lista dos vinte produtos mais vendidos para a África no governo Lula (2003-2010)

\begin{tabular}{|c|c|c|c|c|c|}
\hline & NCM & Descrição & Fator Agregado & US\$ & Part. \\
\hline 1 & 17011100 & $\begin{array}{l}\text { Açúcar de cana, em } \\
\text { bruto }\end{array}$ & $\begin{array}{c}\text { PRODUTOS } \\
\text { SEMIMANUFATURADOS }\end{array}$ & 6.911 .250 .366 & $12,07 \%$ \\
\hline 2 & 17019900 & $\begin{array}{l}\text { Outros açúcares de } \\
\text { cana, beterraba, } \\
\text { sacarose } \\
\text { quimicamente pura, } \\
\text { sol. }\end{array}$ & $\begin{array}{c}\text { PRODUTOS } \\
\text { MANUFATURADOS }\end{array}$ & 6.583 .501 .129 & $11,50 \%$ \\
\hline 3 & 27101159 & Outras gasolinas & $\begin{array}{c}\text { PRODUTOS } \\
\text { MANUFATURADOS }\end{array}$ & 3.386.168.738 & $5,91 \%$ \\
\hline 4 & 02023000 & $\begin{array}{l}\begin{array}{l}\text { Carnes desossadas de } \\
\text { bovino, congeladas }\end{array} \\
\end{array}$ & PRODUTOS BASICOS & 3.385.011.158 & $5,91 \%$ \\
\hline 5 & 26011200 & $\begin{array}{l}\text { Minérios de ferro } \\
\text { aglomerados e seus } \\
\text { concentrados }\end{array}$ & PRODUTOS BASICOS & 2.984.978.518 & $5,21 \%$ \\
\hline 6 & 02071400 & $\begin{array}{l}\text { Pedaços e miudezas, } \\
\text { comestíveis de } \\
\text { galos/galinhas, } \\
\text { congelados }\end{array}$ & PRODUTOS BASICOS & 1.496 .339 .169 & $2,61 \%$ \\
\hline 7 & 15071000 & $\begin{array}{l}\text { Óleo de soja, em } \\
\text { bruto, mesmo } \\
\text { degomado }\end{array}$ & $\begin{array}{c}\text { PRODUTOS } \\
\text { SEMIMANUFATURADOS }\end{array}$ & 1.070 .404 .177 & $1,87 \%$ \\
\hline 8 & 02071200 & $\begin{array}{l}\text { Carnes de } \\
\text { galos/galinhas, não } \\
\text { cortadas em pedaços, } \\
\text { congelala }\end{array}$ & PRODUTOS BASICOS & 908.067 .728 & $1,59 \%$ \\
\hline 9 & 87060010 & $\begin{array}{l}\text { Chassis com motor } \\
\text { para veículos } \\
\text { automóveis } \\
\text { transporte pessoas >= } \\
10\end{array}$ & $\begin{array}{c}\text { PRODUTOS } \\
\text { MANUFATURADOS }\end{array}$ & 867.084 .458 & $1,51 \%$ \\
\hline
\end{tabular}




\begin{tabular}{|c|c|c|c|c|c|}
\hline 10 & 24012030 & \begin{tabular}{|l|} 
Tabaco não \\
manufaturado, total \\
ou parcialmente \\
destalado, em folhas \\
secas em secador de \\
ar quente (flue cured), \\
do tipo Virgínia
\end{tabular} & PRODUTOS BASICOS & 799.166 .848 & $1,40 \%$ \\
\hline 11 & 28182010 & Alumina calcinada & $\begin{array}{c}\text { PRODUTOS } \\
\text { MANUFATURADOS }\end{array}$ & 763.574 .347 & $1,33 \%$ \\
\hline 12 & 87012000 & $\begin{array}{l}\text { Tratores rodoviários } \\
\text { para semi-reboques }\end{array}$ & $\begin{array}{c}\text { PRODUTOS } \\
\text { MANUFATURADOS }\end{array}$ & 756.229 .967 & $1,32 \%$ \\
\hline 13 & 10059010 & $\begin{array}{l}\text { Milho em grão, exceto } \\
\text { para semeadura }\end{array}$ & PRODUTOS BASICOS & 600.605 .884 & $1,05 \%$ \\
\hline 14 & 87019090 & Outros tratores & $\begin{array}{c}\text { PRODUTOS } \\
\text { MANUFATURADOS }\end{array}$ & 575.849 .334 & $1,01 \%$ \\
\hline 15 & 88024090 & $\begin{array}{l}\text { Outros aviões e } \\
\text { outros veículos } \\
\text { aéreos, de peso } \\
\text { superior a } 15.000 \mathrm{~kg} \text {, } \\
\text { vazios }\end{array}$ & $\begin{array}{c}\text { PRODUTOS } \\
\text { MANUFATURADOS }\end{array}$ & 568.441 .144 & $0,99 \%$ \\
\hline 16 & 87043190 & $\begin{array}{l}\text { Outros veículos } \\
\text { automóveis com } \\
\text { motor a explosão, } \\
\text { carga <= } 5 \text { toneladas }\end{array}$ & $\begin{array}{c}\text { PRODUTOS } \\
\text { MANUFATURADOS }\end{array}$ & 499.975 .228 & $0,87 \%$ \\
\hline 17 & 87079090 & $\begin{array}{l}\text { Carrocerias para } \\
\text { veículos automóveis } \\
\text { com capacidade de } \\
\text { transporte => } 10 \\
\text { pessoas, ou para } \\
\text { carga }\end{array}$ & $\begin{array}{c}\text { PRODUTOS } \\
\text { MANUFATURADOS }\end{array}$ & 495.601 .593 & $0,87 \%$ \\
\hline 18 & 12010090 & $\begin{array}{l}\text { Outros grãos de soja, } \\
\text { mesmo triturados }\end{array}$ & PRODUTOS BASICOS & 453.292 .585 & $0,79 \%$ \\
\hline 19 & 87042310 & \begin{tabular}{|l|} 
Chassis com motor \\
diesel e cabina, \\
capacidade de carga > \\
20 toneladas \\
\end{tabular} & $\begin{array}{c}\text { PRODUTOS } \\
\text { MANUFATURADOS }\end{array}$ & 452.573 .922 & $0,79 \%$ \\
\hline 20 & 72142000 & $\begin{array}{l}\text { Barras de ferro ou aço } \\
\text { não ligado, a quente, } \\
\text { dentadas, com } \\
\text { nervuras, sulcos ou } \\
\text { relevos, obtidos } \\
\text { durante a laminagem, } \\
\text { ou torcidas após } \\
\text { laminagem }\end{array}$ & $\begin{array}{c}\text { PRODUTOS } \\
\text { MANUFATURADOS }\end{array}$ & 449.880 .361 & $0,79 \%$ \\
\hline
\end{tabular}

Fonte: Elaboração própria a partir de dados do Aliceweb (BRASIL, 2014a).

O primeiro item da pauta de exportações do Brasil para a África que não correspondeu a commodities foi o nono colocado: chassis com motor para veículos automóveis de transporte 
pessoas, com apenas $1,51 \%$ de participação do total vendido. O cruzamento das informações da Nomenclatura Comum do Mercosul (NCM) com a lista de commodities da metodologia de classificação do MDIC revela que 53,45\% do valor das vendas para a África nos anos Lula eram de produtos dessa categoria. Ao todo, foram 189 tipos de commodities comercializadas, em uma lista de 353 itens comercializados pelo Brasil. Nos anos FHC, o percentual foi um pouco maior, 56,90\%. Durante o governo de Lula, o valor comercializado de commodities alcançou US\$ 30,6 bilhões dos US\$ 57,2 bilhões exportados nos oito anos de governo.

Gráfico 20: As principais commodities vendidas para a África no governo Lula (2003-2010)

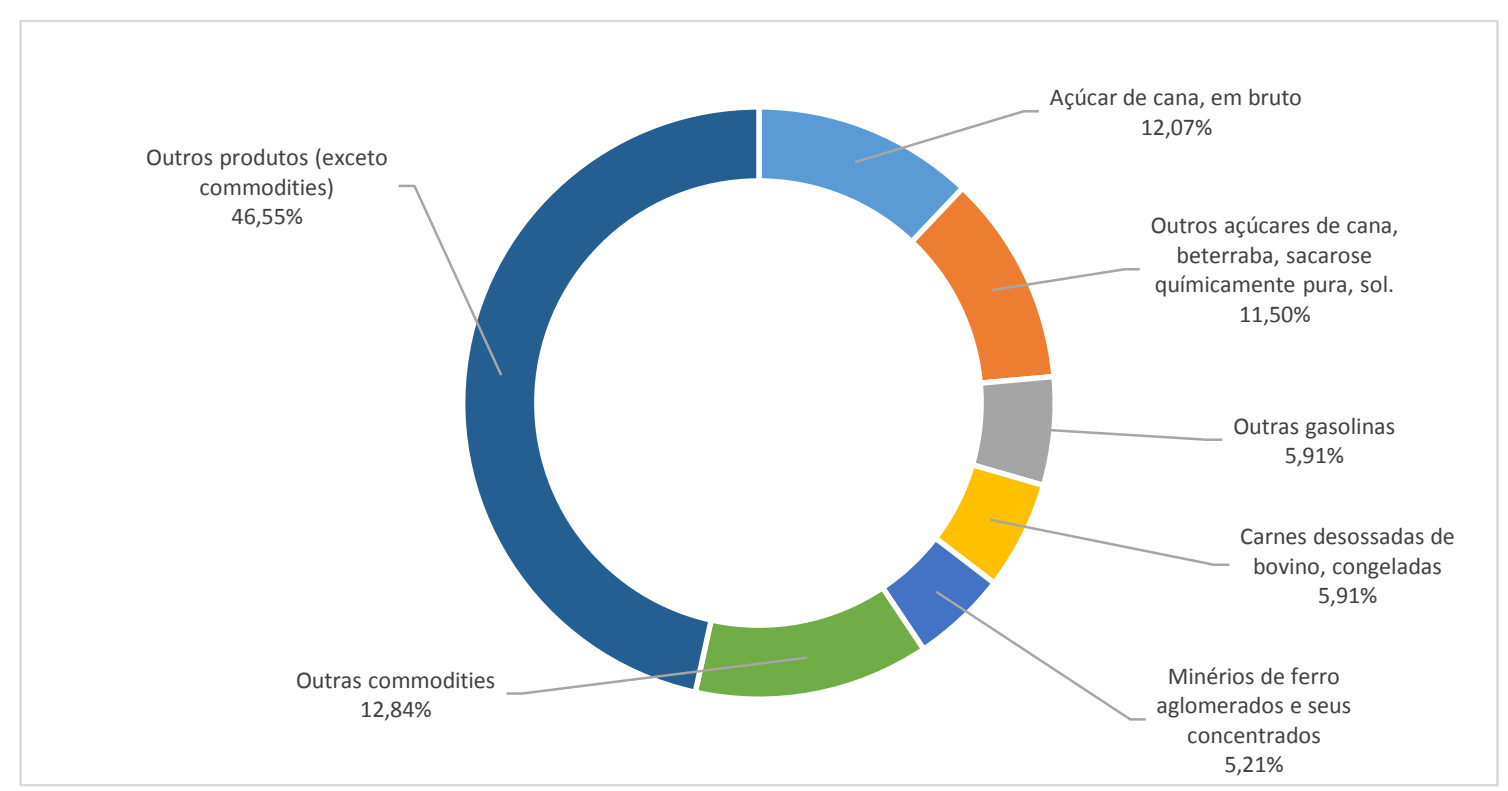

Fonte: Elaboração própria a partir de dados do Aliceweb (BRASIL, 2014a).

Ao longo dos dois mandatos do presidente Lula, nota-se uma concentração das exportações brasileiras em um número pequeno de países na África, a mesma observação feita nos anos FHC. Entre 2003 e 2010, quatro países africanos compraram sozinhos mais da metade do total das exportações feitas pelo Brasil para o continente do outro lado do Atlântico. África do Sul, Nigéria, Egito e Angola se revezaram no topo do ranking de principais destinos. Na maior parte do tempo, o comércio somado desses países ultrapassou os $60 \%$. Apenas nos dois últimos anos de governo Lula, o percentual de concentração geográfica caiu levemente e o percentual do segundo mandato fechou em 55\%. Na quinta posição dos principais compradores de produtos brasileiros, alternam-se Marrocos e Argélia. Esses mesmos seis países são os que aparecem como destaque na análise do período de governo FHC. Existem, no entanto, trocas de posição no ranking. 
Tabela 26: Os cinco principais destinos das mercadorias brasileiras na África entre 2003 e 2010 / Valores de exportação em dólar (US\$ FOB)

\begin{tabular}{|l|c|c|l|c|c|}
\hline País & $\mathbf{2 0 0 3}$ & Part. & País & $\mathbf{2 0 0 4}$ & Part. \\
\hline África do Sul & 733.986 .967 & $26 \%$ & África do Sul & 1.037 .166 .657 & $24 \%$ \\
\hline Nigéria & 469.730 .463 & $16 \%$ & Egito & 623.626 .705 & $15 \%$ \\
\hline Egito & 462.132 .733 & $16 \%$ & Nigéria & 505.235 .218 & $12 \%$ \\
\hline Angola & 235.469 .291 & $8 \%$ & Angola & 357.150 .788 & $12 \%$ \\
\hline Marrocos & 226.505 .090 & $8 \%$ & Marrocos & 348.988 .512 & $12 \%$ \\
\hline
\end{tabular}

\begin{tabular}{|l|r|c|l|c|c|}
\hline País & \multicolumn{1}{|c|}{$\mathbf{2 0 0 5}$} & Part. & País & 2006 & Part. \\
\hline África do Sul & 1.371 .135 .092 & $23 \%$ & África do Sul & 1.462 .736 .565 & $20 \%$ \\
\hline Nigéria & 953.225 .828 & $16 \%$ & Nigéria & 1.373 .624 .268 & $18 \%$ \\
\hline Egito & 868.236 .333 & $15 \%$ & Egito & 1.349 .482 .973 & $18 \%$ \\
\hline Angola & 521.326 .869 & $9 \%$ & Angola & 837.778 .648 & $11 \%$ \\
\hline Marrocos & 414.165 .273 & $7 \%$ & Argélia & 456.723 .333 & $6 \%$ \\
\hline
\end{tabular}

\begin{tabular}{|l|c|c|l|c|c|}
\hline País & $\mathbf{2 0 0 7}$ & Part. & País & $\mathbf{2 0 0 8}$ & Part. \\
\hline África do Sul & 1.757 .857 .900 & $20 \%$ & Angola & 1.974 .575 .752 & $19 \%$ \\
\hline Nigéria & 1.512 .357 .010 & $18 \%$ & África do Sul & 1.754 .848 .262 & $17 \%$ \\
\hline Egito & 1.238 .382 .477 & $14 \%$ & Nigéria & 1.535 .589 .616 & $15 \%$ \\
\hline Angola & 1.218 .235 .629 & $14 \%$ & Egito & 1.408 .639 .245 & $14 \%$ \\
\hline Argélia & 501.249 .282 & $6 \%$ & Argélia & 632.486 .469 & $6 \%$ \\
\hline
\end{tabular}

\begin{tabular}{|l|c|c|l|r|c|}
\hline País & $\mathbf{2 0 0 9}$ & Part. & País & $\mathbf{2 0 1 0}$ & Part. \\
\hline Egito & 1.443 .980 .525 & $17 \%$ & Egito & 1.967 .533 .716 & $21 \%$ \\
\hline Angola & 1.333 .008 .513 & $15 \%$ & África do Sul & 1.309 .974 .026 & $14 \%$ \\
\hline África do Sul & 1.259 .699 .806 & $14 \%$ & Angola & 947.119 .243 & $10 \%$ \\
\hline Nigéria & 1.066 .462 .807 & $12 \%$ & Nigéria & 862.541 .036 & $9 \%$ \\
\hline Argélia & 714.191 .423 & $8 \%$ & Argélia & 838.751 .875 & $9 \%$ \\
\hline
\end{tabular}

Fonte: Elaboração própria a partir de dados do Aliceweb (BRASIL, 2014a).

A África do Sul foi o principal destino das mercadorias brasileiras na África durante cinco anos, nos anos Lula. No período FHC, o país ocupou a posição durante três anos apenas. Angola, que nos anos de Cardoso, surgiu como quinto ou sexto colocado, em alguns momentos; durante o governo Lula, chegou a ocupar o primeiro lugar no topo, em 2008. E Egito, antes quatro vezes principal destino das mercadorias brasileiras na África, nos anos Cardoso, esteve em primeiro em apenas duas oportunidades no período entre 2003 e 2010. 
Gráfico 21: Perfil dos principais produtos vendidos para África do Sul (2003-2010)

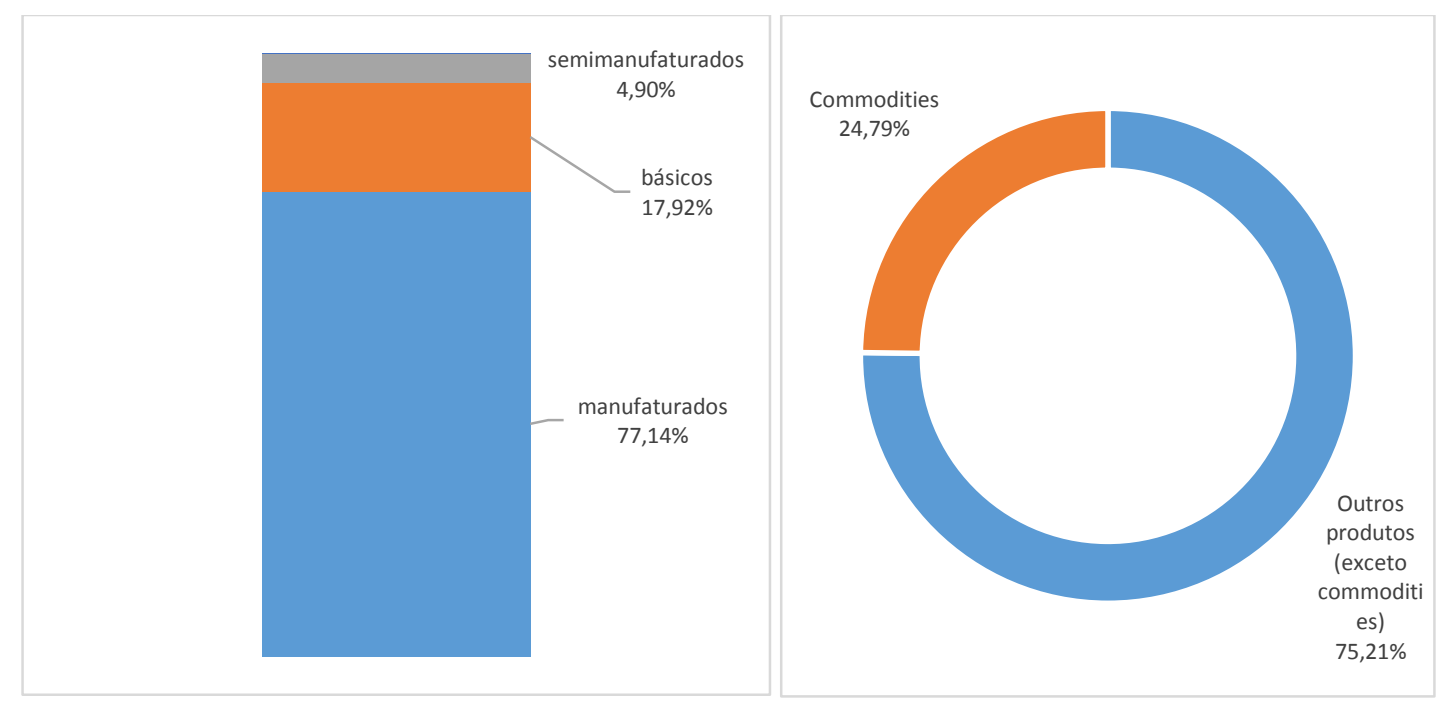

Fonte: Elaboração própria a partir de dados do Aliceweb (BRASIL, 2014a).

Os valores não somam $100 \%$ por causa das operações especiais.

Tabela 27: Lista dos principais produtos vendidos para África do Sul (2003-2010)

\begin{tabular}{|c|c|l|c|c|c|}
\cline { 2 - 6 } \multicolumn{1}{c|}{ NCM } & \multicolumn{1}{c|}{ Descrição } & Fator Agregado & US\$ & Part. \\
\hline 1 & 02071400 & $\begin{array}{l}\text { Pedaços e miudezas, comestíveis de } \\
\text { galos/galinhas, congelados }\end{array}$ & $\begin{array}{c}\text { PRODUTOS } \\
\text { BASICOS }\end{array}$ & 817.124 .432 & $7,65 \%$ \\
\hline 2 & 17019900 & $\begin{array}{l}\text { Outros açúcares de cana, beterraba, } \\
\text { sacarose quimicamente pura, sol. }\end{array}$ & $\begin{array}{c}\text { PRODUTOS } \\
\text { MANUFATURADOS }\end{array}$ & 555.933 .772 & $5,20 \%$ \\
\hline 3 & 87043190 & $\begin{array}{l}\text { Outros veículos automóveis com motor } \\
\text { a explosão, carga <= 5 toneladas }\end{array}$ & $\begin{array}{c}\text { PRODUTOS } \\
\text { MANUFATURADOS }\end{array}$ & 495.552 .481 & $4,64 \%$ \\
\hline 5 & 87079090 & $\begin{array}{l}\text { Carrocerias para veículos automóveis } \\
\text { com capacidade de transporte => 10 } \\
\text { pessoas, ou para carga }\end{array}$ & $\begin{array}{c}\text { PRODUTOS } \\
\text { MANUFATURADOS }\end{array}$ & 384.281 .906 & $3,60 \%$ \\
\hline 6 & 87089990 & $\begin{array}{l}\text { Outras partes e acessórios para tratores } \\
\text { e veículos automóveis } \\
\text { reboques }\end{array}$ & $\begin{array}{c}\text { PRODUTOS } \\
\text { MANUFATURADOS }\end{array}$ & 350.632 .693 & $3,28 \%$ \\
\hline 7 & 15079019 & $\begin{array}{l}\text { Óleo de soja, refinado, em recipientes } \\
\text { com capacidade menor que 5 litros }\end{array}$ & $\begin{array}{c}\text { PRODUTOS } \\
\text { MANUFATURADOS }\end{array}$ & 348.455 .160 & $3,26 \%$ \\
\hline 8 & 24012030 & $\begin{array}{l}\text { Tabaco não manufaturado, total ou } \\
\text { parcialmente destalado, em folhas } \\
\text { secas em secador de ar quente (flue } \\
\text { cured), do tipo Virgínia }\end{array}$ & $\begin{array}{l}\text { PRODUTOS } \\
\text { BASICOS }\end{array}$ & 335.147 .693 & $3,14 \%$ \\
\hline 9 & 87060010 & $\begin{array}{l}\text { Chassis com motor para veículos } \\
\text { automóveis transporte pessoas >= 10 }\end{array}$ & $\begin{array}{l}\text { PRODUTOS } \\
\text { MANUFATURADOS }\end{array}$ & 306.031 .358 & $2,86 \%$ \\
\hline $\begin{array}{l}\text { Outras partes e acessórios de } \\
\text { carrocerias para veículos automóveis }\end{array}$ & $\begin{array}{c}\text { PRODUTOS } \\
\text { MANUFATURADOS }\end{array}$ & 279.616 .660 & $2,62 \%$ \\
\hline
\end{tabular}

Fonte: Elaboração própria a partir de dados do Aliceweb (BRASIL, 2014a). 
Gráfico 22: Perfil dos principais produtos vendidos para Angola (2003-2010)

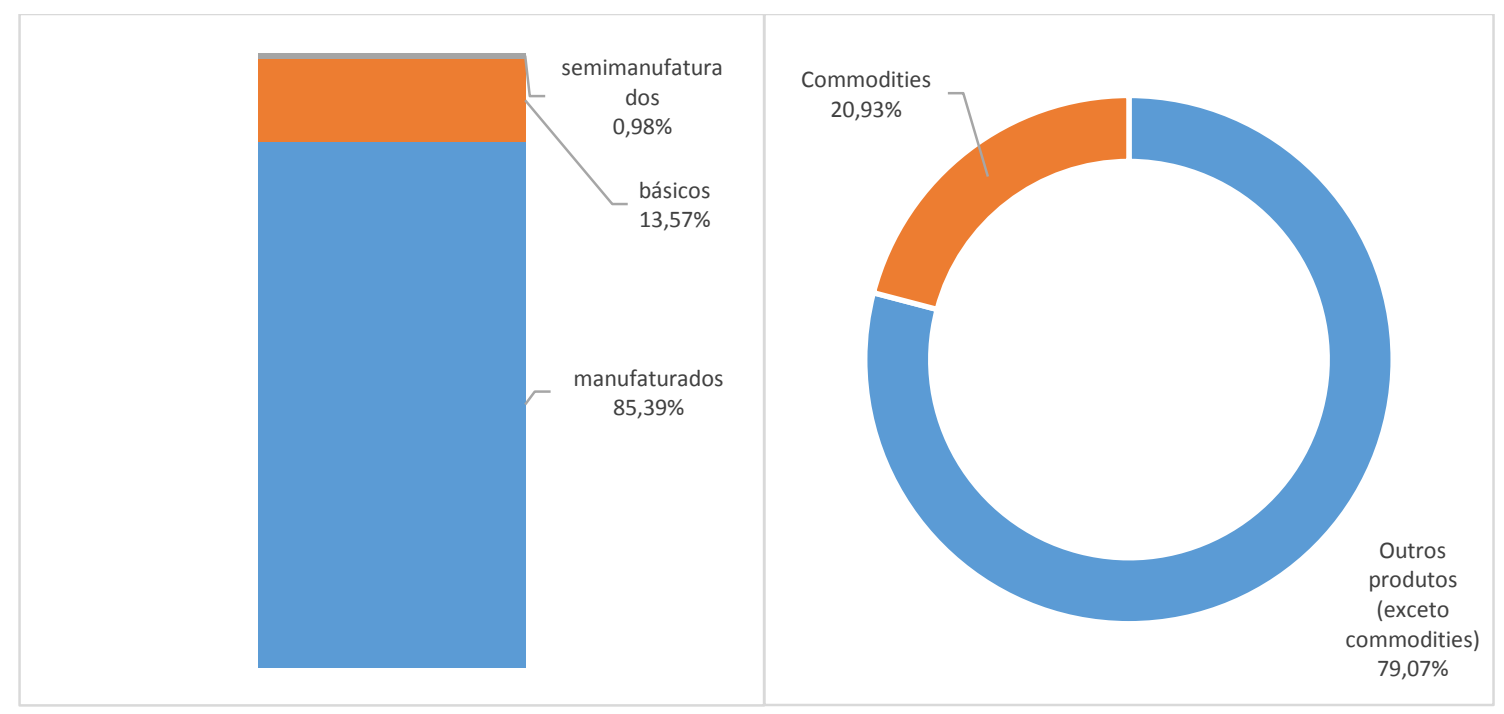

Fonte: Elaboração própria a partir de dados do Aliceweb (BRASIL, 2014a).

Os valores não somam $100 \%$ por causa das operações especiais.

Tabela 28: Lista dos principais produtos vendidos para Angola (2003-2010)

\begin{tabular}{|c|c|c|c|c|c|}
\hline & NCM & Descrição & Fator Agregado & US\$ & Part. \\
\hline 1 & 17019900 & $\begin{array}{l}\text { Outros açúcares de cana, beterraba, } \\
\text { sacarose quimicamente pura, sol. }\end{array}$ & $\begin{array}{c}\text { PRODUTOS } \\
\text { MANUFATURADOS }\end{array}$ & 558.136 .813 & $7,52 \%$ \\
\hline 2 & 87042310 & $\begin{array}{l}\text { Chassis com motor diesel e cabina, } \\
\text { capacidade de carga }>20 \text { toneladas }\end{array}$ & $\begin{array}{c}\text { PRODUTOS } \\
\text { MANUFATURADOS }\end{array}$ & 261.803 .679 & $3,53 \%$ \\
\hline 3 & 02071200 & $\begin{array}{l}\text { Carnes de galos/galinhas, não } \\
\text { cortadas em pedaços, congelala }\end{array}$ & PRODUTOS BASICOS & 235.847 .444 & $3,18 \%$ \\
\hline 4 & 27101159 & Outras gasolinas & $\begin{array}{c}\text { PRODUTOS } \\
\text { MANUFATURADOS }\end{array}$ & 213.636 .908 & $2,88 \%$ \\
\hline 5 & 87012000 & $\begin{array}{l}\text { Tratores rodoviários para semi- } \\
\text { reboques }\end{array}$ & $\begin{array}{c}\text { PRODUTOS } \\
\text { MANUFATURADOS }\end{array}$ & 190.645 .072 & $2,57 \%$ \\
\hline 6 & 72142000 & $\begin{array}{l}\text { Barras de ferro ou aço não ligado, a } \\
\text { quente, dentadas, com nervuras, } \\
\text { sulcos ou relevos, obtidos durante a } \\
\text { laminagem, ou torcidas após } \\
\text { laminagem }\end{array}$ & $\begin{array}{l}\text { PRODUTOS } \\
\text { MANUFATURADOS }\end{array}$ & 160.345 .115 & $2,16 \%$ \\
\hline 7 & 02071400 & $\begin{array}{l}\text { Pedaços e miudezas, comestíveis de } \\
\text { galos/galinhas, congelados }\end{array}$ & PRODUTOS BASICOS & 156.587 .659 & $2,11 \%$ \\
\hline 8 & 94060092 & $\begin{array}{l}\text { Outras construções pré-fabricadas, } \\
\text { com estrutura de ferro ou aço e } \\
\text { paredes exteriores constituídas } \\
\text { essencialmente dessas matérias }\end{array}$ & $\begin{array}{c}\text { PRODUTOS } \\
\text { MANUFATURADOS }\end{array}$ & 149.440 .673 & $2,01 \%$ \\
\hline 9 & 02032900 & Outras carnes de suíno, congeladas & PRODUTOS BASICOS & 136.932 .894 & $1,84 \%$ \\
\hline 10 & 94036000 & Outros móveis de madeira & $\begin{array}{c}\text { PRODUTOS } \\
\text { MANUFATURADOS }\end{array}$ & 135.075 .012 & $1,82 \%$ \\
\hline
\end{tabular}

Fonte: Elaboração própria a partir de dados do Aliceweb (BRASIL, 2014a). 
Gráfico 23: Perfil dos principais produtos vendidos para Argélia (2003-2010)

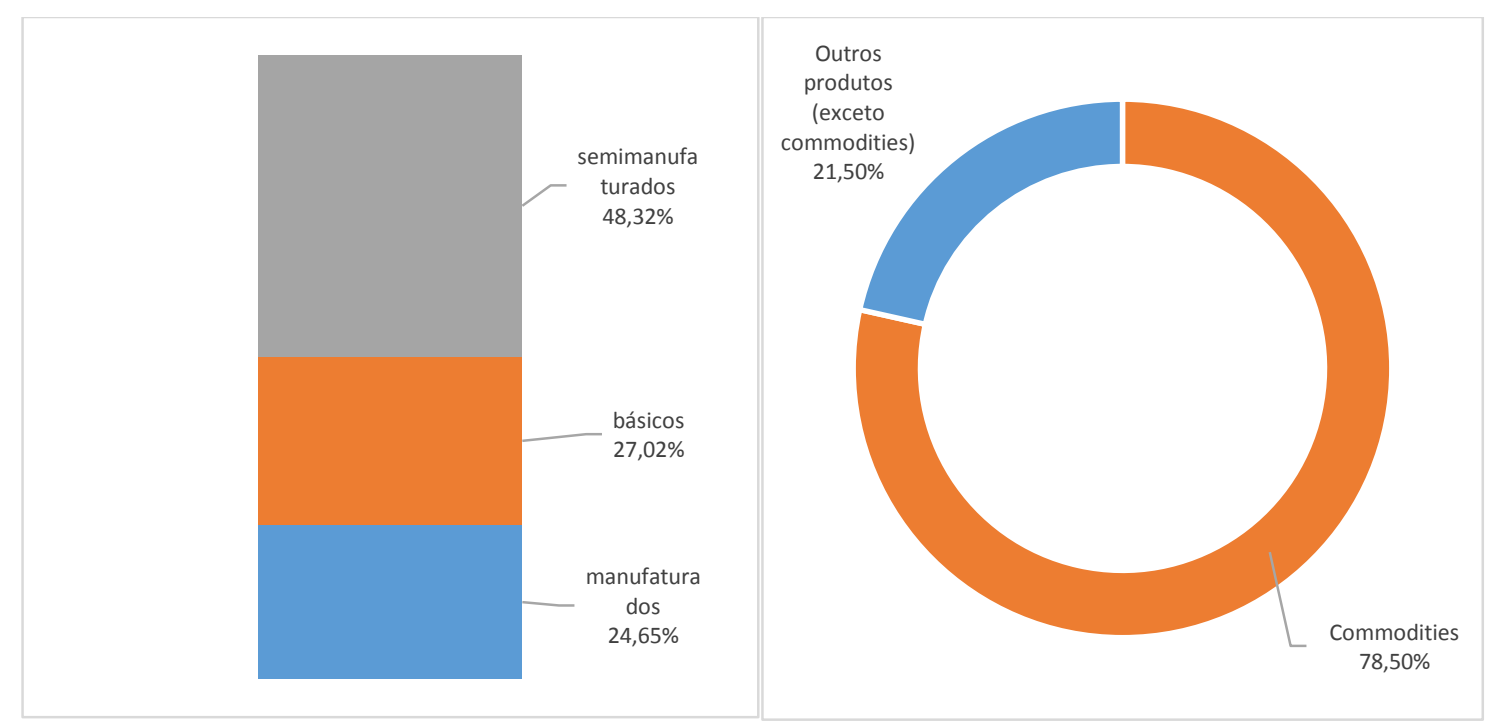

Fonte: Elaboração própria a partir de dados do Aliceweb (BRASIL, 2014a).

Os valores não somam $100 \%$ por causa das operações especiais.

Tabela 29: Lista dos principais produtos vendidos para Argélia (2003-2010)

\begin{tabular}{|c|c|c|c|c|c|}
\hline & NCM & Descrição & Fator Agregado & US\$ & Part. \\
\hline 1 & 17011100 & Açúcar de cana, em bruto & $\begin{array}{c}\text { PRODUTOS } \\
\text { SEMIMANUFATURADOS }\end{array}$ & 1.685 .507 .025 & $41,82 \%$ \\
\hline 2 & 02023000 & $\begin{array}{l}\text { Carnes desossadas de bovino, } \\
\text { congeladas }\end{array}$ & PRODUTOS BASICOS & 751.769 .412 & $18,65 \%$ \\
\hline 3 & 15071000 & $\begin{array}{l}\text { Óleo de soja, em bruto, mesmo } \\
\text { degomado }\end{array}$ & $\begin{array}{c}\text { PRODUTOS } \\
\text { SEMIMANUFATURADOS }\end{array}$ & 261.316 .346 & $6,48 \%$ \\
\hline 4 & 17019900 & $\begin{array}{l}\text { Outros açúcares de cana, } \\
\text { beterraba, sacarose } \\
\text { quimicamente pura, sol. }\end{array}$ & $\begin{array}{c}\text { PRODUTOS } \\
\text { MANUFATURADOS }\end{array}$ & 228.104 .283 & $5,66 \%$ \\
\hline 5 & 10059010 & $\begin{array}{l}\text { Milho em grão, exceto para } \\
\text { semeadura }\end{array}$ & PRODUTOS BASICOS & 122.948 .247 & $3,05 \%$ \\
\hline 6 & 04022110 & $\begin{array}{l}\text { Leite integral, em pó, com um } \\
\text { teor, em peso, de matérias } \\
\text { gordas, superior a } 1,5 \% \text {, sem } \\
\text { adição de açúcar ou de outros } \\
\text { edulcorantes }\end{array}$ & $\begin{array}{l}\text { PRODUTOS } \\
\text { MANUFATURADOS }\end{array}$ & 103.919 .857 & $2,58 \%$ \\
\hline 7 & 10019090 & $\begin{array}{l}\text { Trigo (exceto trigo duro ou para } \\
\text { semeadura), e trigo com centeio }\end{array}$ & PRODUTOS BASICOS & 76.697 .506 & $1,90 \%$ \\
\hline 8 & 87163900 & $\begin{array}{l}\text { Outros reboques e semi- } \\
\text { reboques para transporte de } \\
\text { mercadorias }\end{array}$ & $\begin{array}{l}\text { PRODUTOS } \\
\text { MANUFATURADOS }\end{array}$ & 46.545 .855 & $1,15 \%$ \\
\hline 9 & 85461000 & $\begin{array}{l}\text { Isoladores de vidro para uso } \\
\text { elétrico }\end{array}$ & $\begin{array}{c}\text { PRODUTOS } \\
\text { MANUFATURADOS }\end{array}$ & 46.140 .497 & $1,14 \%$ \\
\hline 10 & 84291190 & $\begin{array}{l}\text { Outros bulldozers e angledozers, } \\
\text { de lagartas }\end{array}$ & $\begin{array}{c}\text { PRODUTOS } \\
\text { MANUFATURADOS }\end{array}$ & 42.659 .669 & $1,06 \%$ \\
\hline
\end{tabular}

Fonte: Elaboração própria a partir de dados do Aliceweb (BRASIL, 2014a). 
Gráfico 24: Perfil dos principais produtos vendidos para o Egito (2003-2010)

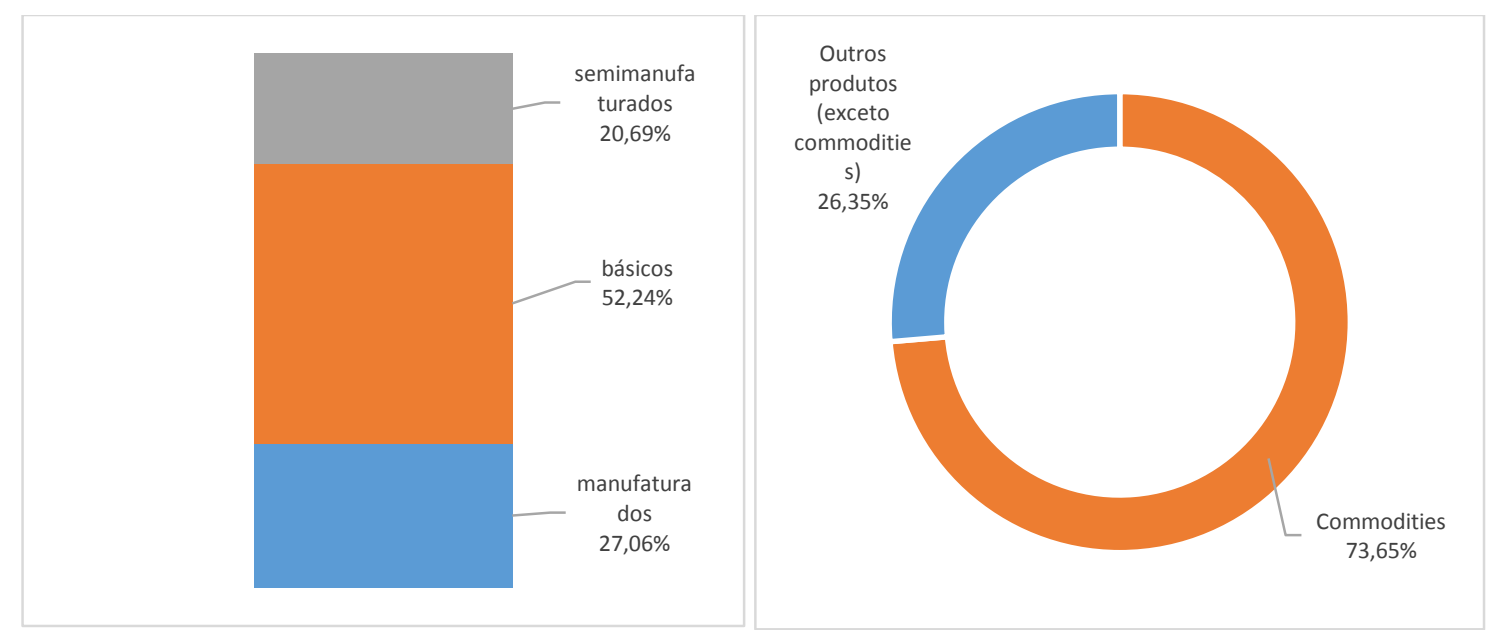

Fonte: Elaboração própria a partir de dados do Aliceweb (BRASIL, 2014a).

Os valores não somam $100 \%$ por causa das operações especiais.

Tabela 30: Lista dos principais produtos vendidos para o Egito (2003-2010)

\begin{tabular}{|c|c|c|c|c|c|}
\hline & NCM & Descrição & Fator Agregado & US\$ & Part. \\
\hline 1 & 02023000 & $\begin{array}{c}\text { Carnes desossadas de bovino, } \\
\text { congeladas }\end{array}$ & PRODUTOS BASICOS & 2.023.485.091 & $21,61 \%$ \\
\hline 2 & 26011200 & $\begin{array}{l}\text { Minérios de ferro aglomerados e } \\
\text { seus concentrados }\end{array}$ & PRODUTOS BASICOS & 1.832.102.029 & $19,57 \%$ \\
\hline 3 & 17011100 & Açúcar de cana, em bruto & $\begin{array}{c}\text { PRODUTOS } \\
\text { SEMIMANUFATURADOS }\end{array}$ & 1.745 .803 .570 & $18,65 \%$ \\
\hline 4 & 28182010 & Alumina calcinada & $\begin{array}{c}\text { PRODUTOS } \\
\text { MANUFATURADOS }\end{array}$ & 464.789.246 & $4,96 \%$ \\
\hline 5 & 02071200 & $\begin{array}{l}\text { Carnes de galos/galinhas, não } \\
\text { cortadas em pedaços, congelala }\end{array}$ & PRODUTOS BASICOS & 370.736 .625 & $3,96 \%$ \\
\hline 6 & 87060010 & $\begin{array}{l}\text { Chassis com motor para veículos } \\
\text { automóveis transporte pessoas } \\
>>=10\end{array}$ & $\begin{array}{c}\text { PRODUTOS } \\
\text { MANUFATURADOS }\end{array}$ & 351.563 .241 & $3,76 \%$ \\
\hline 7 & 88024090 & $\begin{array}{c}\text { Outros aviões e outros veículos } \\
\text { aéreos, de peso superior a } \\
15.000 \mathrm{~kg} \text {, vazios }\end{array}$ & $\begin{array}{c}\text { PRODUTOS } \\
\text { MANUFATURADOS }\end{array}$ & 298.840 .511 & $3,19 \%$ \\
\hline 8 & 24012030 & $\begin{array}{l}\text { Tabaco não manufaturado, total } \\
\text { ou parcialmente destalado, em } \\
\text { folhas secas em secador de ar } \\
\text { quente (flue cured), do tipo } \\
\text { Virgínia }\end{array}$ & PRODUTOS BASICOS & 226.863 .228 & $2,42 \%$ \\
\hline 9 & 17019900 & $\begin{array}{l}\text { Outros açúcares de cana, } \\
\text { beterraba, sacarose } \\
\text { quimicamente pura, sol. }\end{array}$ & $\begin{array}{c}\text { PRODUTOS } \\
\text { MANUFATURADOS }\end{array}$ & 200.250 .775 & $2,14 \%$ \\
\hline 10 & 15071000 & $\begin{array}{l}\text { Óleo de soja, em bruto, mesmo } \\
\text { degomado }\end{array}$ & $\begin{array}{c}\text { PRODUTOS } \\
\text { SEMIMANUFATURADOS }\end{array}$ & 147.521 .960 & $1,58 \%$ \\
\hline
\end{tabular}

Fonte: Elaboração própria a partir de dados do Aliceweb (BRASIL, 2014a). 
Gráfico 25: Perfil dos principais produtos vendidos para o Marrocos (2003-2010)

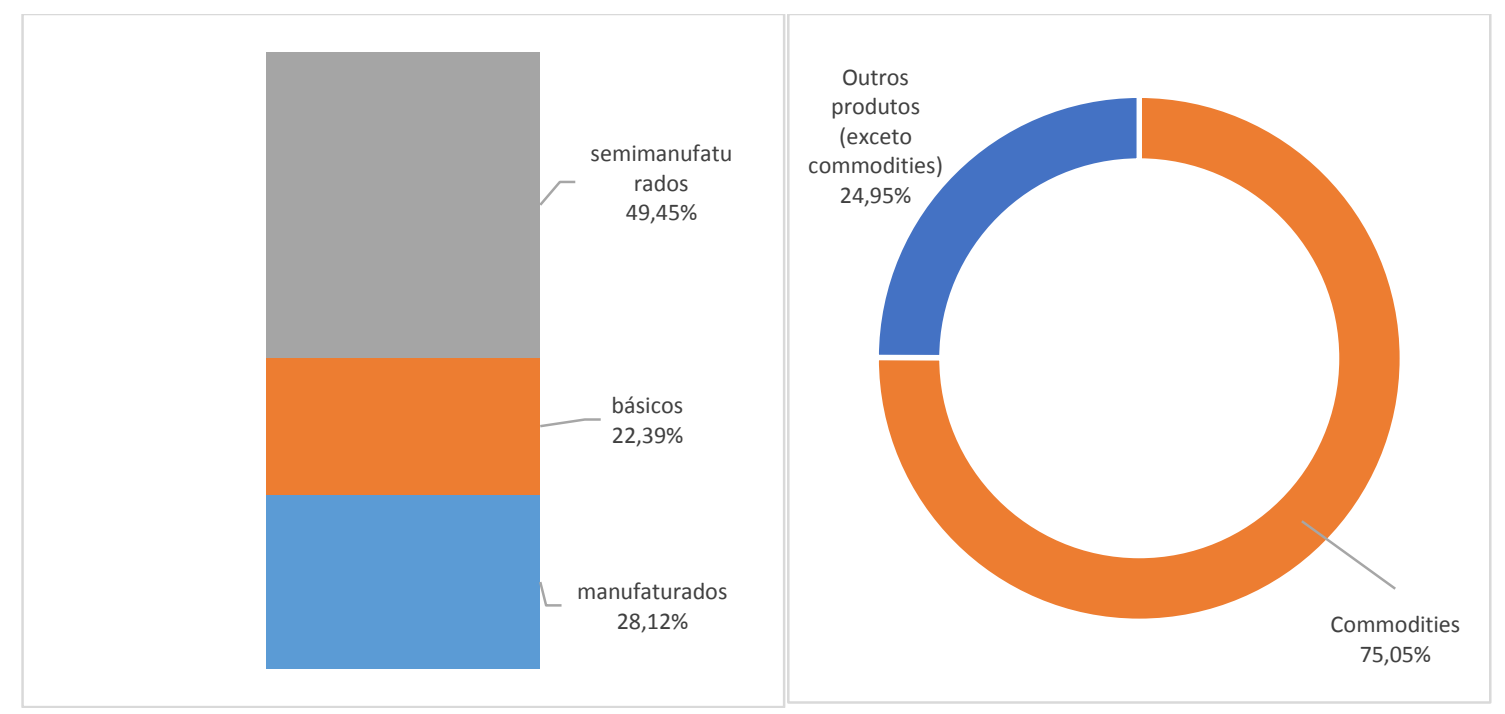

Fonte: Elaboração própria a partir de dados do Aliceweb (BRASIL, 2014a).

Os valores não somam $100 \%$ por causa das operações especiais.

Tabela 31: Lista dos principais produtos vendidos para o Marrocos (2003-2010)

\begin{tabular}{|c|c|c|c|c|c|}
\hline & NCM & Descrição & Fator Agregado & US\$ & Part. \\
\hline 1 & 17011100 & Açúcar de cana, em bruto & $\begin{array}{c}\text { PRODUTOS } \\
\text { SEMIMANUFATURADOS }\end{array}$ & 1.277 .370 .343 & $35,76 \%$ \\
\hline 2 & 17019900 & $\begin{array}{c}\text { Outros açúcares de cana, } \\
\text { beterraba, sacarose quimicamente } \\
\text { pura, sol. }\end{array}$ & $\begin{array}{c}\text { PRODUTOS } \\
\text { MANUFATURADOS }\end{array}$ & 318.341 .056 & $8,91 \%$ \\
\hline 3 & 12010090 & $\begin{array}{l}\text { Outros grãos de soja, mesmo } \\
\text { triturados }\end{array}$ & PRODUTOS BASICOS & 315.359 .606 & $8,83 \%$ \\
\hline 4 & 10059010 & $\begin{array}{l}\text { Milho em grão, exceto para } \\
\text { semeadura }\end{array}$ & PRODUTOS BASICOS & 304.155 .543 & $8,51 \%$ \\
\hline 5 & 15071000 & $\begin{array}{c}\text { Óleo de soja, em bruto, mesmo } \\
\text { degomado }\end{array}$ & $\begin{array}{c}\text { PRODUTOS } \\
\text { SEMIMANUFATURADOS }\end{array}$ & 209.660 .590 & $5,87 \%$ \\
\hline 6 & 72071110 & $\begin{array}{l}\text { Billets de ferro ou aço não ligado, } \\
\text { de seção transversal quadrada ou } \\
\text { retangular, com largura inferior a } \\
\text { duas vezes a espessura, que } \\
\text { contenham, em peso, menos de } \\
0,25 \% \text { de carbono }\end{array}$ & $\begin{array}{c}\text { PRODUTOS } \\
\text { SEMIMANUFATURADOS }\end{array}$ & 112.111 .699 & $3,14 \%$ \\
\hline 7 & 87019090 & Outros tratores & $\begin{array}{c}\text { PRODUTOS } \\
\text { MANUFATURADOS }\end{array}$ & 104.745 .892 & $2,93 \%$ \\
\hline 8 & 44071000 & $\begin{array}{l}\text { Madeira de coníferas, serrada ou } \\
\text { fendida longitudinalmente, } \\
\text { cortada transversalmente ou } \\
\text { desenrolada, mesmo aplainada, } \\
\text { lixada ou unida pelas } \\
\text { extremidades, de espessura } \\
\text { superior a } 6 \mathrm{~mm}\end{array}$ & $\begin{array}{c}\text { PRODUTOS } \\
\text { SEMIMANUFATURADOS }\end{array}$ & 100.888 .252 & $2,82 \%$ \\
\hline 9 & 10019090 & $\begin{array}{l}\text { Trigo (exceto trigo duro ou para } \\
\text { semeadura), e trigo com centeio }\end{array}$ & PRODUTOS BASICOS & 91.113 .769 & $2,55 \%$ \\
\hline 10 & 87012000 & $\begin{array}{l}\text { Tratores rodoviários para semi- } \\
\text { reboques }\end{array}$ & $\begin{array}{c}\text { PRODUTOS } \\
\text { MANUFATURADOS }\end{array}$ & 76.033 .346 & $2,13 \%$ \\
\hline
\end{tabular}

Fonte: Elaboração própria a partir de dados do Aliceweb (BRASIL, 2014a). 
Gráfico 26: Perfil dos principais produtos vendidos para a Nigéria (2003-2010)

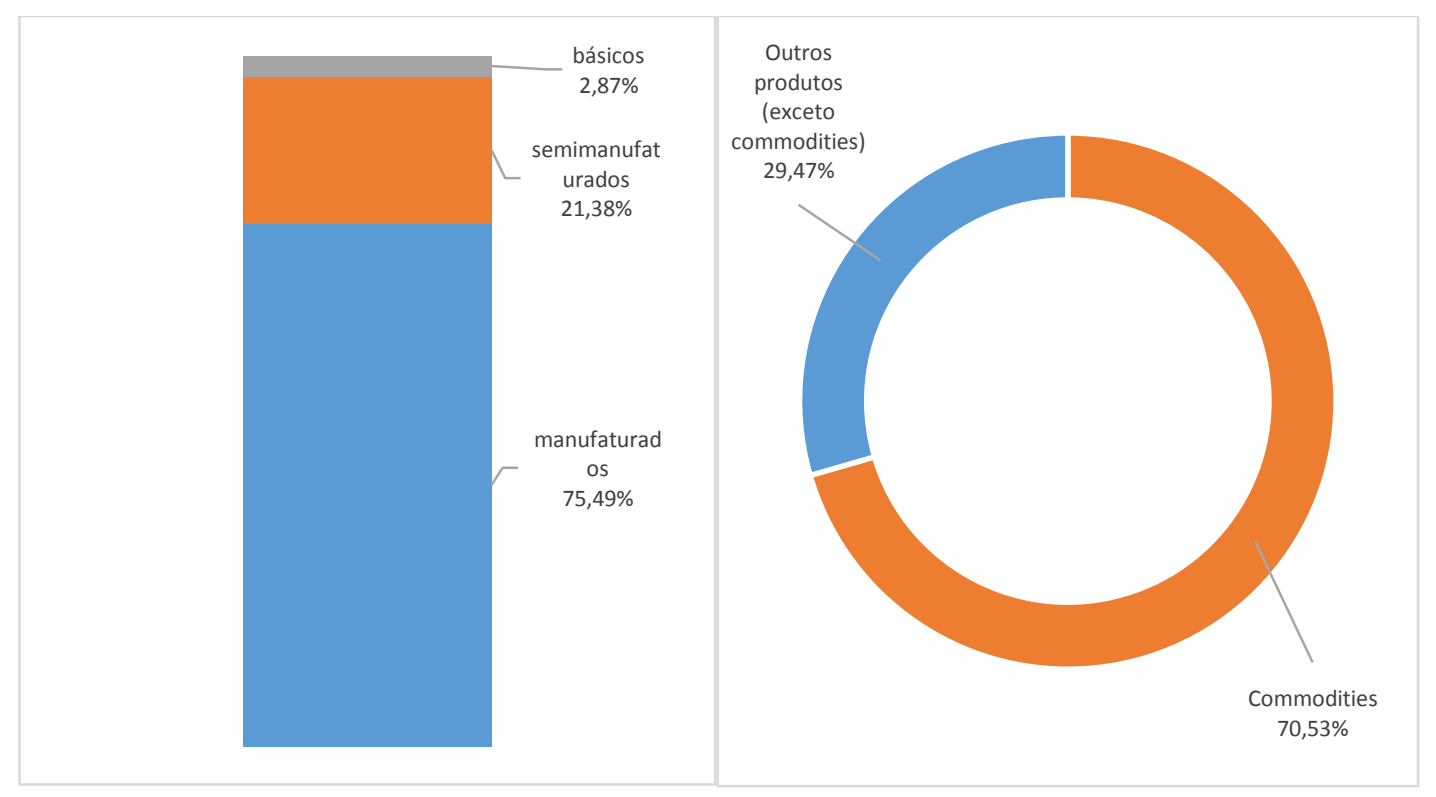

Fonte: Elaboração própria a partir de dados do Aliceweb (BRASIL, 2014a).

Os valores não somam $100 \%$ por causa das operações especiais.

Tabela 32: Lista dos principais produtos vendidos para a Nigéria (2003-2010)

\begin{tabular}{|c|c|c|c|c|c|}
\hline & NCM & Descrição & Fator Agregado & US\$ & Part. \\
\hline 1 & 27101159 & Outras gasolinas & $\begin{array}{c}\text { PRODUTOS } \\
\text { MANUFATURADOS }\end{array}$ & 2.800 .012 .751 & $33,82 \%$ \\
\hline 2 & 17011100 & Açúcar de cana, em bruto & $\begin{array}{c}\text { PRODUTOS } \\
\text { SEMIMANUFATURADOS }\end{array}$ & 1.618 .506 .675 & $19,55 \%$ \\
\hline 3 & 17019900 & $\begin{array}{l}\text { Outros açúcares de cana, beterraba, } \\
\text { sacarose quimicamente pura, sol. }\end{array}$ & $\begin{array}{c}\text { PRODUTOS } \\
\text { MANUFATURADOS }\end{array}$ & 904.621 .821 & $10,93 \%$ \\
\hline 4 & 22071000 & $\begin{array}{c}\text { Álcool etílico não desnaturado, com } \\
\text { volume de teor alcoólico }>=80 \%\end{array}$ & $\begin{array}{c}\text { PRODUTOS } \\
\text { MANUFATURADOS }\end{array}$ & 264.445 .215 & $3,19 \%$ \\
\hline 5 & 29224220 & Sais do ácido glutâmico & $\begin{array}{c}\text { PRODUTOS } \\
\text { MANUFATURADOS }\end{array}$ & 238.211 .084 & $2,88 \%$ \\
\hline 6 & 87021000 & $\begin{array}{l}\text { Veículos automóveis para transporte } \\
\text { de dez pessoas ou mais, incluindo o } \\
\text { motorista, com motor de pistão, de } \\
\text { ignição por compressão (diesel ou } \\
\text { semidiesel) }\end{array}$ & $\begin{array}{c}\text { PRODUTOS } \\
\text { MANUFATURADOS }\end{array}$ & 216.044 .626 & $2,61 \%$ \\
\hline 7 & 39021020 & $\begin{array}{c}\text { Polipropileno sem carga, em forma } \\
\text { primária }\end{array}$ & $\begin{array}{c}\text { PRODUTOS } \\
\text { MANUFATURADOS }\end{array}$ & 132.645 .807 & $1,60 \%$ \\
\hline 8 & 27101931 & Óleos lubrificantes sem aditivos & $\begin{array}{c}\text { PRODUTOS } \\
\text { MANUFATURADOS }\end{array}$ & 104.143 .667 & $1,26 \%$ \\
\hline 9 & 10063011 & $\begin{array}{c}\text { Arroz semibranqueado ou } \\
\text { branqueado, parboilizado, polido ou } \\
\text { brunido }\end{array}$ & PRODUTOS BASICOS & 80.149 .945 & $0,97 \%$ \\
\hline 10 & 72142000 & $\begin{array}{l}\text { Barras de ferro ou aço não ligado, a } \\
\text { quente, dentadas, com nervuras, } \\
\text { sulcos ou relevos, obtidos durante a } \\
\text { laminagem, ou torcidas após } \\
\text { laminagem }\end{array}$ & $\begin{array}{c}\text { PRODUTOS } \\
\text { MANUFATURADOS }\end{array}$ & 78.649 .314 & $0,95 \%$ \\
\hline
\end{tabular}

Fonte: Elaboração própria a partir de dados do Aliceweb (BRASIL, 2014a). 
A avaliação das vendas para os seis principais países compradores de mercadorias brasileiras na África, durante o governo Lula, mostrou Angola como o destino do menor percentual de commodities, 20,93\%; no governo, FHC o índice era de 27,88\%. Angola também comprou mais mercadorias manufaturadas, $85,39 \%$ do total, nos anos entre 2003 e 2010; entre 1997 e 2002, o percentual era de 80,96\%. A África do Sul, que tinha o menor índice de commodities nos anos de governo de Cardoso, aumentou o peso desse tipo de produto nas exportações, o percentual passou de 18,06\% para 24,79\%. Houve também um leve recuo no índice de manufaturados, que era de 79,71\% e ficou em 77,14. As características gerais das exportações feitas para os outros quatro países de destaque, Argélia, Egito, Marrocos e Nigéria, se mostraram bem próximas daquelas percebidas no estudo do comércio nos anos Cardoso: um significativo peso das commodities na cesta de produtos. Para esses quatro países, o percentual desse tipo de mercadoria ultrapassou os $70 \%$. O percentual de manufaturados registrado foi pequeno, abaixo de $30 \%$ para Argélia, Egito e Marrocos. Para a Nigéria, o peso dos manufaturados alcançou 75,49\%. Um alto percentual dessas mercadorias são commodities com algum beneficiamento, como açúcar em bruto, óleo de soja bruto e couro bovino; e também commodities industrializadas, como gasolina, açúcar de cana e óleo diesel. O total de commodities classificadas como do tipo básico, semimanufaturado e manufaturado alcançou $70,53 \%$ do valor exportado.

No comércio com a África do Sul, os dois principais produtos vendidos durante o governo Lula eram commodities. Um contraste ao constatado no estudo do período anterior, quando automóveis e aviões lideravam o topo da lista. No caso de Angola, aviões ocupavam a terceira posição no ranking e desapareceram da lista dos dez mais vendidos no governo Lula. Não houve mudança no item mais procurado pelos angolanos, que permaneceu açúcares de cana, beterraba, sacarose quimicamente pura. O produto mais vendido para o Egito, que era açúcar, portanto manufaturado; passou a ser carnes congeladas desossadas de bovino, classificadas como básicas. Nos demais itens da lista, houve pouca alteração. O açúcar foi o mais procurado pelo Marrocos, como constatado também durante o governo FHC. O Brasil aumentou o peso da venda de gasolina para a Nigéria, o percentual, que era de 6,64\%, passou a $33,82 \%$ e tomou o topo da lista dos itens brasileiros mais procurados pelos nigerianos, reflexo da grande deficiência de refinarias no país africano (ANÁLISE EDITORAL, 2010). 
Tabela 33: Os cinco principais mercados fornecedores do Brasil na África entre 2003 e 2010. Valores de importação em dólar (US\$ FOB)

\begin{tabular}{|l|r|c|l|r|c|}
\hline País & \multicolumn{1}{|c|}{$\mathbf{2 0 0 3}$} & Part. & País & 2004 & Part. \\
\hline Nigéria & 1.521 .661 .990 & $46 \%$ & Nigéria & 3.501 .030 .240 & $57 \%$ \\
\hline Argélia & 1.123 .047 .090 & $34 \%$ & Argélia & 1.944 .465 .672 & $31 \%$ \\
\hline África do Sul & 202.203 .391 & $6 \%$ & África do Sul & 268.097 .881 & $4 \%$ \\
\hline Marrocos & 202.000 .279 & $6 \%$ & Marrocos & 241.036 .838 & $4 \%$ \\
\hline Congo & 63.688 .768 & $2 \%$ & Tunísia & 74.185 .542 & $1 \%$ \\
\hline
\end{tabular}

\begin{tabular}{|l|c|c|l|c|c|}
\hline País & 2005 & Part. & País & 2006 & Part. \\
\hline Argélia & 2.831 .171 .145 & $43 \%$ & Nigéria & 3.918 .295 .644 & $48 \%$ \\
\hline Nigéria & 2.643 .015 .996 & $40 \%$ & Argélia & 1.970 .701 .657 & $24 \%$ \\
\hline África do Sul & 341.547 .475 & $5 \%$ & Angola & 459.499 .620 & $6 \%$ \\
\hline Marrocos & 311.411 .366 & $5 \%$ & África do Sul & 434.860 .919 & $5 \%$ \\
\hline Guiné Equatorial & 290.678 .306 & $4 \%$ & Marrocos & 331.297 .285 & $4 \%$ \\
\hline
\end{tabular}

\begin{tabular}{|l|c|c|l|c|c|}
\hline País & $\mathbf{2 0 0 7}$ & Part. & País & $\mathbf{2 0 0 8}$ & Part. \\
\hline Nigéria & 5.281 .064 .357 & $47 \%$ & Nigéria & 6.704 .379 .120 & $43 \%$ \\
\hline Argélia & 2.236 .411 .459 & $20 \%$ & Argélia & 2.501 .415 .208 & $16 \%$ \\
\hline Líbia & 997.675 .054 & $9 \%$ & Angola & 2.236 .426 .952 & $14 \%$ \\
\hline Angola & 946.332 .224 & $8 \%$ & Líbia & 1.406 .153 .282 & $9 \%$ \\
\hline Marrocos & 532.393 .045 & $5 \%$ & Marrocos & 1.144 .141 .196 & $7 \%$ \\
\hline
\end{tabular}

\begin{tabular}{|c|c|c|c|c|c|}
\hline País & 2009 & Part. & País & 2010 & Part. \\
\hline Nigéria & 4.760 .614 .289 & $56 \%$ & Nigéria & 5.920 .185 .355 & $52 \%$ \\
\hline Argélia & 1.381 .741 .791 & $16 \%$ & Argélia & 2.361 .413 .347 & $21 \%$ \\
\hline Líbia & 835.074 .860 & $10 \%$ & África do Sul & 753.433 .380 & $7 \%$ \\
\hline África do Sul & 433.213 .470 & $5 \%$ & Marrocos & 664.920 .400 & $6 \%$ \\
\hline Marrocos & 339.079 .053 & $4 \%$ & Guiné Equatorial & 509.999 .481 & $5 \%$ \\
\hline
\end{tabular}

Fonte: Elaboração própria a partir de dados do Aliceweb (BRASIL, 2014a).

A maior parte das importações do Brasil veio de poucos países africanos no governo Lula, a mesma concentração geográfica de parceiros percebida no comércio com a África durante os anos Cardoso. Com exceção do Egito, os principais países compradores de produtos brasileiros na África aparecem também entre os que o Brasil mais importa mercadoria. África do Sul, Angola, Argélia, Marrocos e Nigéria aparecem entre os quatro principais fornecedores do Brasil, entre 2003 e 2010. Mais do que isso, a Argélia e a Nigéria polarizaram as importações com um percentual de $71,16 \%$ do total comprado da África pelo Brasil. Sozinha, a Nigéria representou 48,16\% do valor importado entre 2003 e 2010. 
Nos últimos anos, a Nigéria se consolidou como o mais importante mercado de origem de produtos africanos para o Brasil. Em 2006 e 2007, os nigerianos passaram também a ocupar um lugar entre os principais fornecedores brasileiros no mundo. Em 2006 e 2007, a Nigéria apareceu no quinto lugar da lista de origens mais importantes. No final do governo Lula, era o sétimo. Desde 2013, com o significativo aumento das importações brasileiras da Nigéria, o país voltou à quinta posição, atrás apenas de China, Estados Unidos, Argentina e Alemanha (BRASIL, 2015). O mercado brasileiro é o terceiro principal destino das mercadorias da Nigéria. Só Índia e Estados Unidos compram mais da Nigéria do que o Brasil. Mas o Brasil não é um fornecedor tão importante para os nigerianos. Nas importações que a Nigéria faz, os brasileiros aparecem como décimo terceiro na lista dos parceiros mais importantes. Os principais fornecedores para o mercado nigeriano são, na ordem de importância: China, Estados Unidos, Índia, França, Reino Unido, Holanda, Alemanha, Coreia, Bélgica, Emirados Árabes Unidos, Costa do Marfim, Itália e Brasil.

Apesar da alta concentração geográfica no cenário dos principais parceiros na importação, novos países aparecem entre os cinco mais bem colocados, ainda que tenham um percentual pequeno de participação nas vendas. Congo Brazzaville, Guiné Equatorial, Líbia e Tunísia estiveram entre os destaques das origens de mercadorias compradas pelo Brasil; no entanto, o percentual de participação ficou sempre com apenas um dígito.

Gráfico 27: A balança comercial do Brasil com os principais compradores de mercadorias na África: África do Sul, Angola, Argélia, Egito, Marrocos e Nigéria (2003-2010)

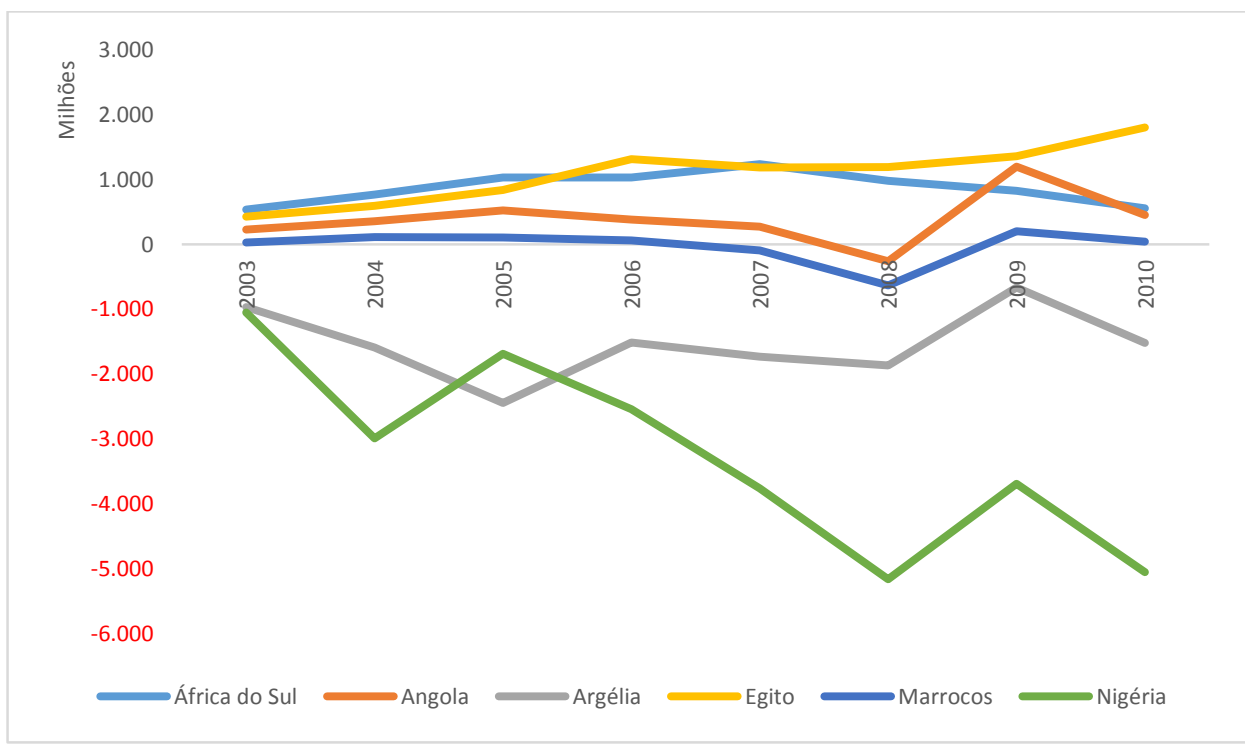

Fonte: Elaboração própria a partir de dados do Aliceweb (BRASIL, 2014a). 
A análise da balança comercial dos seis principais parceiros comerciais brasileiros mostra um resultado superavitário com África do Sul e Egito, durante todos os anos Lula. Com Angola e Marrocos, o resultado foi positivo na maior parte do tempo, as únicas exceções foram um ano de déficit com os angolanos e dois anos com os marroquinos. Os déficits constantes e crescentes registrados entre 2003 e 2010 foram com Argélia e Nigéria. Os valores foram de tal maneira altos e significativos que, se o total do comércio do Brasil com a Argélia e Nigéria fosse excluído da balança com a África, o saldo comercial com o continente teria sido positivo e alto, nos dois mandatos de Lula.

Tabela 34: Balança comercial do Brasil com a África para todos os países e também o total sem Argélia e Nigéria (2003-2010)

\begin{tabular}{|c|c|c|c|c|c|c|c|c|}
\hline & 2003 & 2004 & 2005 & 2006 & 2007 & 2008 & 2009 & 2010 \\
\hline $\begin{array}{l}\text { Balança } \\
\text { Comercial } \\
\text { Brasil-África } \\
\text { (total) }\end{array}$ & -429.171 .024 & -1.935 .773 .511 & -675.311 .072 & -654.931 .755 & -2.768 .503 .231 & -5.591 .557 .002 & 226.798 .220 & -2.035 .651 .862 \\
\hline $\begin{array}{l}\text { Balança } \\
\text { Comercial } \\
\text { Brasil-África } \\
\text { (excluídos } \\
\text { Nigéria e } \\
\text { Argélia) }\end{array}$ & 1.592 .102 .390 & 2.655 .953 .540 & 3.461 .306 .772 & 3.403 .717 .945 & 2.735.366.293 & 1.446 .161 .241 & 4.588 .500 .070 & 4.544 .653 .929 \\
\hline
\end{tabular}

Fonte: Elaboração própria a partir de dados do Aliceweb (BRASIL, 2014a).

O Brasil importa desses destinos praticamente apenas petróleo e derivados. Da Nigéria, 99,72\% do comprado pelo mercado brasileiro se referiam a óleos brutos de petróleo, naftas para petroquímica, gás natural liquefeito, gás liquefeito de petróleo (GLP), butanos liquefeitos, outros propanos liquefeitos e outras naftas. $\mathrm{Na}$ análise da pauta de importações da Argélia, não houve diferença. Do que veio da Argélia, 98,24\% eram óleos brutos de petróleo, naftas para petroquímica, outros propanos liquefeitos e outras naftas.

O peso de petróleo e derivados apareceu como principal característica da pauta de importações da África como um todo. Apenas os óleos brutos de petróleo, produto classificado como básico, representaram 75,50\% de tudo o que foi importado de 2003 a 2010. O percentual representou um salto em relação ao registrado nos anos Cardoso, antes esse percentual era de 40,34\%. As principais origens foram: Nigéria (61,84\%), Argélia (20,15\%), Angola (7,28\%), Líbia $(6,25 \%)$ e Guiné Equatorial (2,80\%). Como constatado no estudo feito do período Cardoso, o produto manufaturado mais comprado pelo Brasil na África foram naftas para petroquímica, com 7,90\% de participação no total importado. Somados, os dois primeiros itens 
da lista alcançaram 83,40\%, em mais uma evidência do domínio do segmento de petróleo nas importações do Brasil na África.

Tabela 35: Os dez principais produtos importados da África pelo Brasil (2003-2010)

\begin{tabular}{|c|c|c|c|c|c|}
\hline & NCM & Descrição & Fator Agregado & US\$ & Part. \\
\hline 1 & 27090010 & Óleos brutos de petróleo & PRODUTOS BASICOS & 53.692 .880 .357 & $75,50 \%$ \\
\hline 2 & 27101141 & Naftas para petroquímica & $\begin{array}{c}\text { PRODUTOS } \\
\text { MANUFATURADOS }\end{array}$ & 5.620 .444 .994 & $7,90 \%$ \\
\hline 3 & 31054000 & $\begin{array}{l}\text { Diidrogeno-ortofosfato de } \\
\text { amônio (fosfato } \\
\text { monoamônico ou } \\
\text { monoamoniacal), mesmo } \\
\text { misturado com hidrogeno- } \\
\text { ortofosfato de diamônio } \\
\text { (fosfato diamônico ou } \\
\text { diamoniacal) }\end{array}$ & $\begin{array}{c}\text { PRODUTOS } \\
\text { MANUFATURADOS }\end{array}$ & 1.141 .841 .417 & $1,61 \%$ \\
\hline 4 & 31031030 & $\begin{array}{l}\text { Superfosfatos, com teor de } \\
\text { pentóxido de fósforo (P2O5) } \\
\text { superior a } 45 \% \text {, em peso }\end{array}$ & $\begin{array}{c}\text { PRODUTOS } \\
\text { MANUFATURADOS }\end{array}$ & 1.096 .350 .195 & $1,54 \%$ \\
\hline 5 & 27111290 & Outros propanos liquefeitos & $\begin{array}{c}\text { PRODUTOS } \\
\text { MANUFATURADOS }\end{array}$ & 967.137 .858 & $1,36 \%$ \\
\hline 6 & 28092019 & Outros ácidos fosfóricos & $\begin{array}{c}\text { PRODUTOS } \\
\text { MANUFATURADOS }\end{array}$ & 741.397.936 & $1,04 \%$ \\
\hline 7 & 25101010 & $\begin{array}{c}\text { Fosfatos de cálcio naturais, } \\
\text { não moídos }\end{array}$ & PRODUTOS BASICOS & 587.788 .983 & $0,83 \%$ \\
\hline 8 & 31053010 & $\begin{array}{c}\text { Hidrogeno-ortofosfato de } \\
\text { diamônio (fosfato diamônico } \\
\text { ou diamoniacal), com teor de } \\
\text { arsênio superior ou igual a } 6 \\
\mathrm{mg} / \mathrm{kg}\end{array}$ & $\begin{array}{c}\text { PRODUTOS } \\
\text { MANUFATURADOS }\end{array}$ & 384.167 .641 & $0,54 \%$ \\
\hline 9 & 18010000 & $\begin{array}{c}\text { Cacau inteiro ou partido, em } \\
\text { bruto ou torrado }\end{array}$ & PRODUTOS BASICOS & 381.544 .675 & $0,54 \%$ \\
\hline 10 & 27011100 & $\begin{array}{l}\text { Hulha antracita, não } \\
\text { aglomerada }\end{array}$ & PRODUTOS BASICOS & 380.750 .088 & $0,54 \%$ \\
\hline
\end{tabular}

Fonte: Elaboração própria a partir de dados do Aliceweb (BRASIL, 2014a). 
Gráfico 28: O perfil dos produtos importados da África (2003-2010)

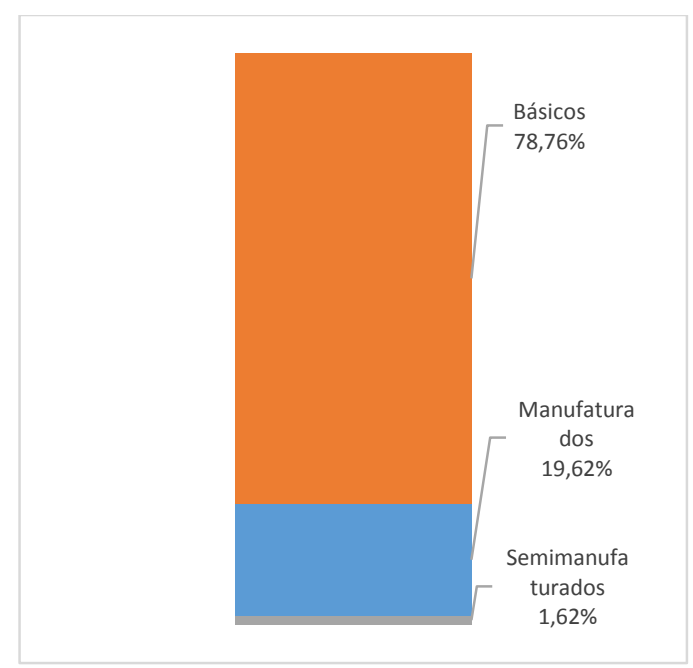

Fonte: Elaboração própria a partir de dados do Aliceweb (BRASIL, 2014a).

Os valores não somam $100 \%$ por causa das operações especiais.

Gráfico 29: As principais commodities compradas da África (2003-2010)

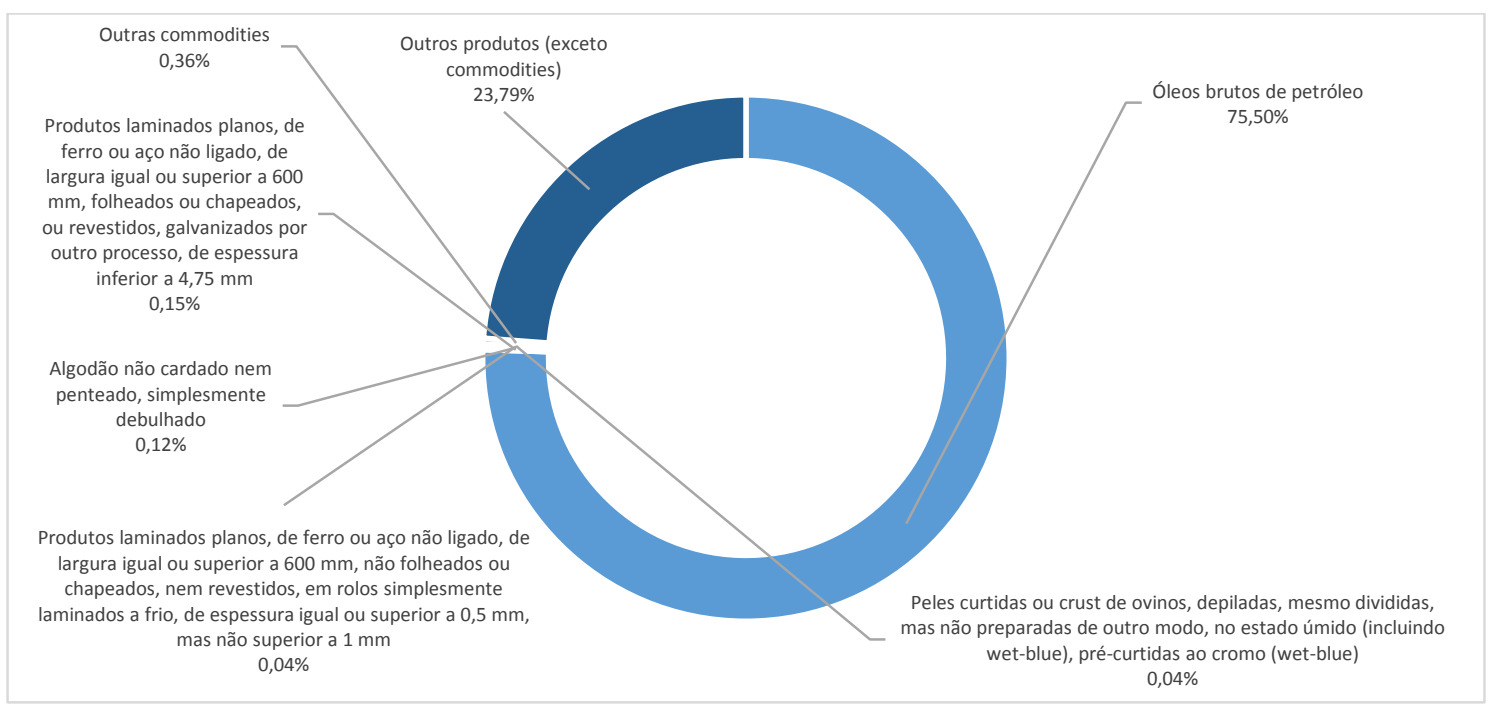

Fonte: Elaboração própria a partir de dados do Aliceweb (BRASIL, 2014a).

Nos anos de governo Lula, cresceu a ênfase na compra de produtos básicos e de commodities produzidas na África. O percentual de básicos, na casa de 48,85\% durante os mandatos de FHC, saltou para 78,76\% nos anos Lula. O percentual de manufaturados despencou de 48,60\% para 19,62\%. Além disso, houve uma disparada no comércio de commodities, que saltou de $46,01 \%$ para $76,21 \%$. O crescimento se deu especialmente pelo aumento da compra de óleos brutos de petróleo, que saltaram de 40,34\% das importações para $75,50 \%$ do total comprado no continente africano. Os números demonstram que o crescimento 
das compras do Brasil em território africano se deu principalmente em razão do comércio de petróleo e derivados.

Mesmo com o aumento do volume financeiro nas trocas com a África, a participação do continente no comércio exterior brasileiro ainda é baixa nas exportações e nas importações. No último ano do segundo mandato, o percentual da África nas exportações era de 4,6\%, atrás de Ásia, América Latina, União Europeia, Estados Unidos e Oriente Médio. Nas importações, os africanos detinham 6,2\% de todas as compras externas do Brasil, atrás de Ásia, União Europeia, América Latina e Caribe, e Estados Unidos.

Gráfico 30: Principais destinos das exportações brasileira em 2010 (\%/participação)

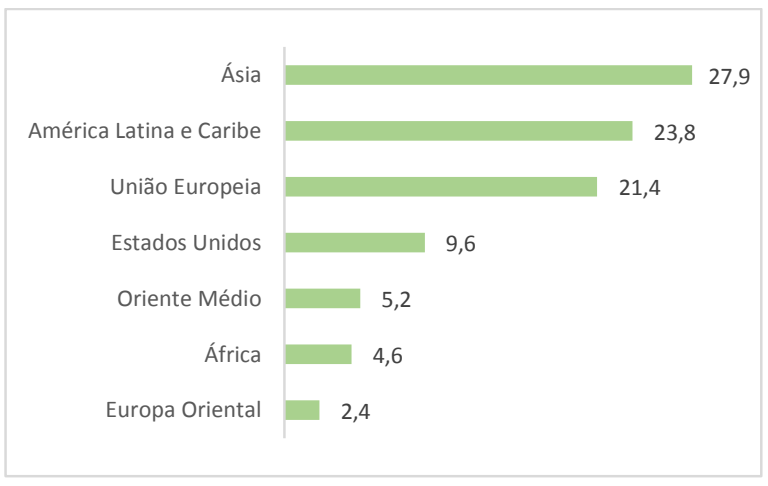

Fonte: BRASIL, 2014c

Gráfico 31: Principais fornecedores do Brasil em 2010 (\%/participação)

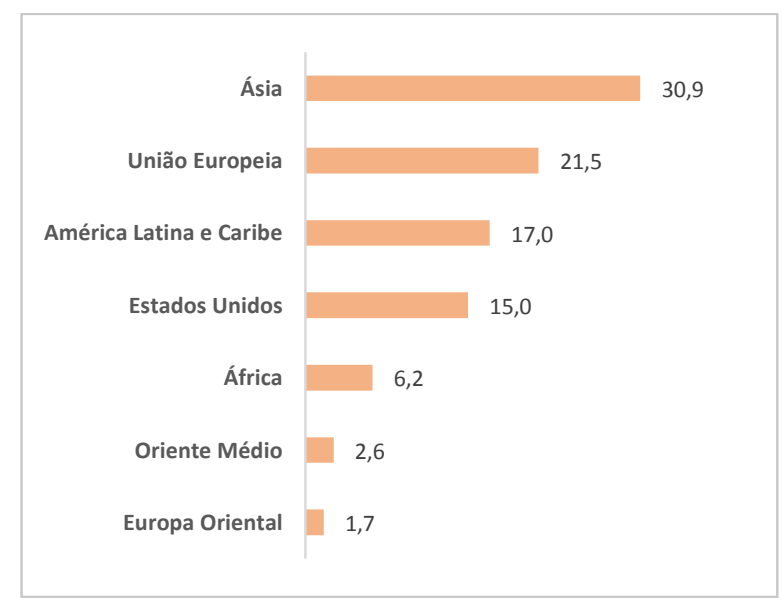

Fonte: BRASIL, 2014c

A despeito do baixo peso relativo da África na balança comercial brasileira, a avaliação do comércio com o continente durante o governo Lula mostra um salto dos valores 
comercializados. As exportações e as importações cresceram e sofreram retração apenas em 2009, possivelmente pelo efeito da crise internacional nas trocas comerciais de todo o mundo. Por outro lado, o déficit comercial se acentuou e pareceu seguir uma direção de crescimento. Durante o governo FHC, o pior déficit foi de US\$ 1,5 bilhões; no governo Lula, o valor chegou a US\$ 5,5 bilhões.

Gráfico 32: A balança comercial do Brasil com a África (1989-2010)

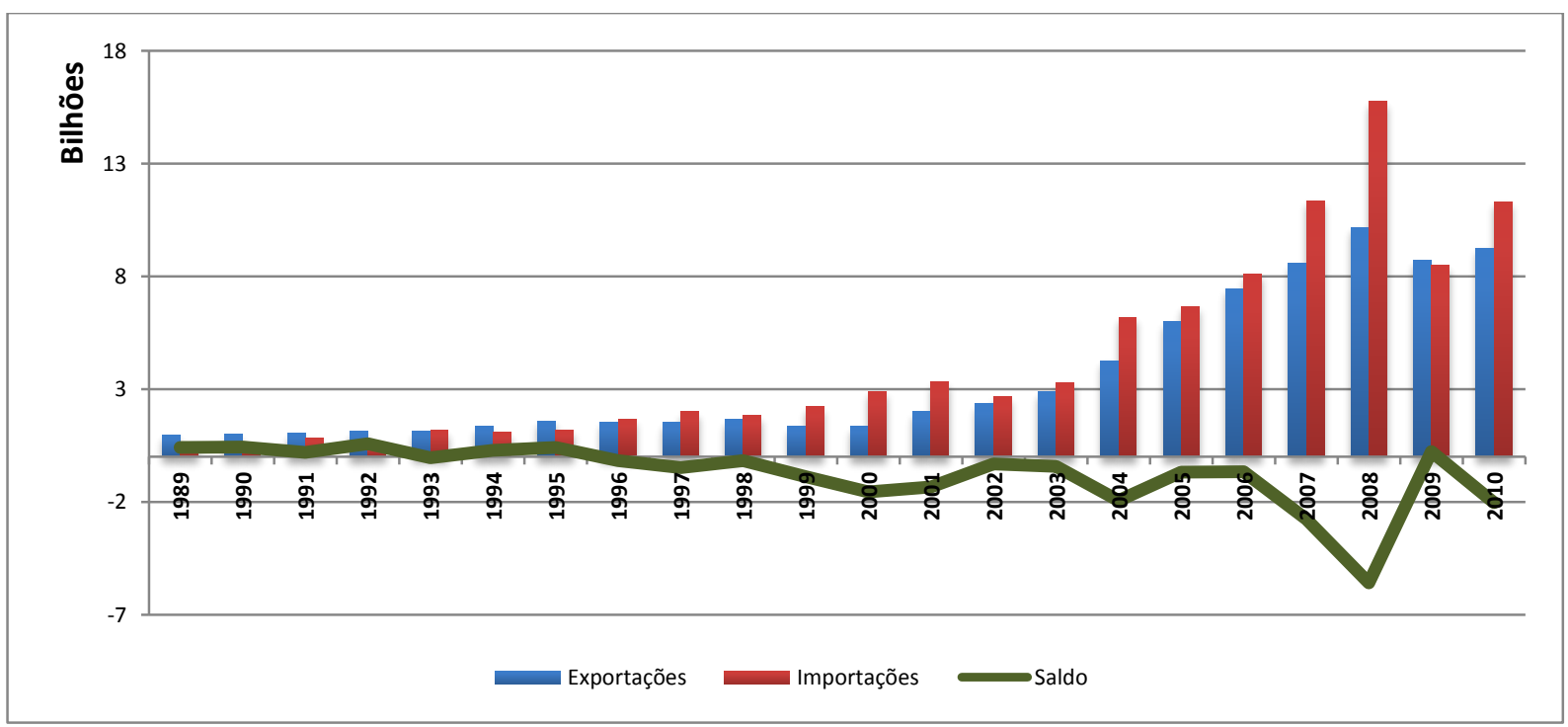

Fonte: Elaboração própria a partir de dados do Aliceweb (BRASIL, 2014a).

A corrente de comércio do Brasil com a África seguiu uma curva de ascensão desde os anos FHC. Nos anos Lula, o crescimento se acentuou consideravelmente, apesar do recuo de 2009. Ao final do governo do PT, o avanço voltou a se repetir. A avalição do período entre 1995 e 2010, revelou que o comércio com a África cresceu em valores significativos. Em 2010, as trocas comerciais equivaleram, em valores absolutos e em dólar, a quase oito vezes mais o que eram em 1995. 
Gráfico 33: O avanço da corrente de comércio entre o Brasil e a África (1995-2010)

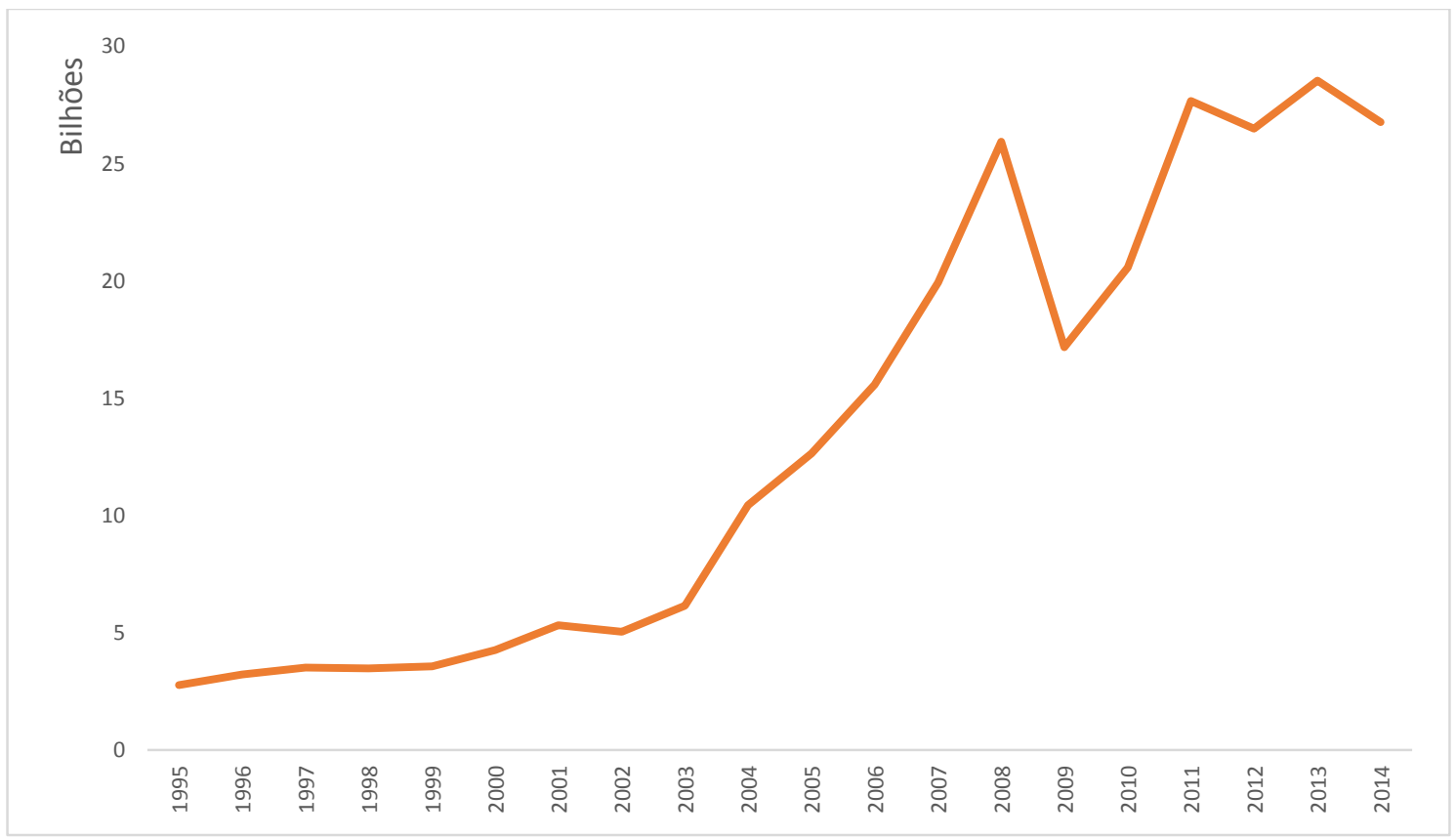

Fonte: Elaboração própria a partir de dados do Aliceweb (BRASIL, 2014a).

Mesmo com o crescimento da corrente de comércio, para Costa e Veiga (2011), a integração da África aos instrumentos de política comercial manejados pelo Brasil deram resultados bastante modestos, no governo Lula. A agenda de promoção comercial da Agência Brasileira de Promoção de Exportações e Investimentos, a Apex-Brasil, subordinada ao Ministério do Desenvolvimento, Indústria e Comércio Exterior (MDIC), tratou a África como um mercado regional na maior parte do tempo, embora o continente integrasse programas setoriais de promoção. Em 2008 e 2009, a APEX promoveu várias missões de exploração de oportunidades e rodadas de negócios em países da África; apenas em 2010, contudo, abriu o primeiro Centro de Negócios no continente africano, em Luanda, Angola, voltado para a provisão de serviços de inteligência de mercado, promoção de negócios e apoio à instalação local de empresas brasileiras. Para os autores, somente no caso das exportações para Angola, financiadas pelo BNDES, pode-se dizer que a África ganhou alguma expressão na política comercial brasileira (COSTA; VEIGA, 2011, p. 17-19).

O principal instrumento de política comercial unilateral utilizado pelo Brasil nas suas relações comerciais com a África, ainda segundo Costa e Veiga, tem sido o financiamento público às exportações. O mecanismo tradicionalmente utilizado, desde a década de 1970, foi o Programa de Financiamento às Exportações, o Proex, instrumento público de apoio às 
exportações brasileiras de bens e serviços que tem o Banco do Brasil como agente financeiro da União. A importância relativa do Proex, acreditam os autores, se explica pelo fato de suas linhas financiarem a exportação de serviços há mais tempo do que o BNDES e contarem com recursos do Tesouro Nacional, que seriam mais adequados para a provisão de créditos a países de risco político relativamente elevado. As linhas de financiamento do BNDES-Exim somente começaram a ser usadas nas exportações para a África a partir de 2007, na sequência da assinatura dos Protocolos de Entendimentos entre Brasil e Angola. A participação dos países africanos no total dos desembolsos do BNDES em financiamentos às exportações passou de 3,6\% do total, em 2007, para 9,2\%, em 2009. Um ano depois, houve forte queda e a participação africana foi a 1,6\% dos desembolsos do BNDES na área de exportação (Ibidem).

O ceticismo em relação ao sucesso do comércio exterior do Brasil com a África tem ainda outro argumento: o de que o Brasil não aproveitou todo o potencial do mercado africano. Apesar de o Brasil aparecer entre os dez principais compradores em volume financeiro da África, o país ocupa apenas a décima sexta posição entre os principais países que exportam para o continente africano e com um percentual pequeno. Segundo dados do Fundo Monetário Internacional (FMI), o Brasil foi o nono principal destino dos produtos africanos no mundo, em 2013, o último dado disponível, atrás apenas de China, Estados Unidos, Espanha, França, Índia, Holanda, Reino Unido e Itália. Em 2013, entre os parceiros mais importantes de onde vêm as mercadorias compradas pela África, apareceram à frente do Brasil: China, França, Estados Unidos, Índia, Alemanha, Itália, Espanha, África do Sul, Arábia Saudita, Coreia do Sul, Reino Unido, Japão, Holanda, Nigéria e Bélgica. 
Gráfico 34: Os dez principais compradores de mercadorias da África no mundo (US\$ milhões/ 2013)

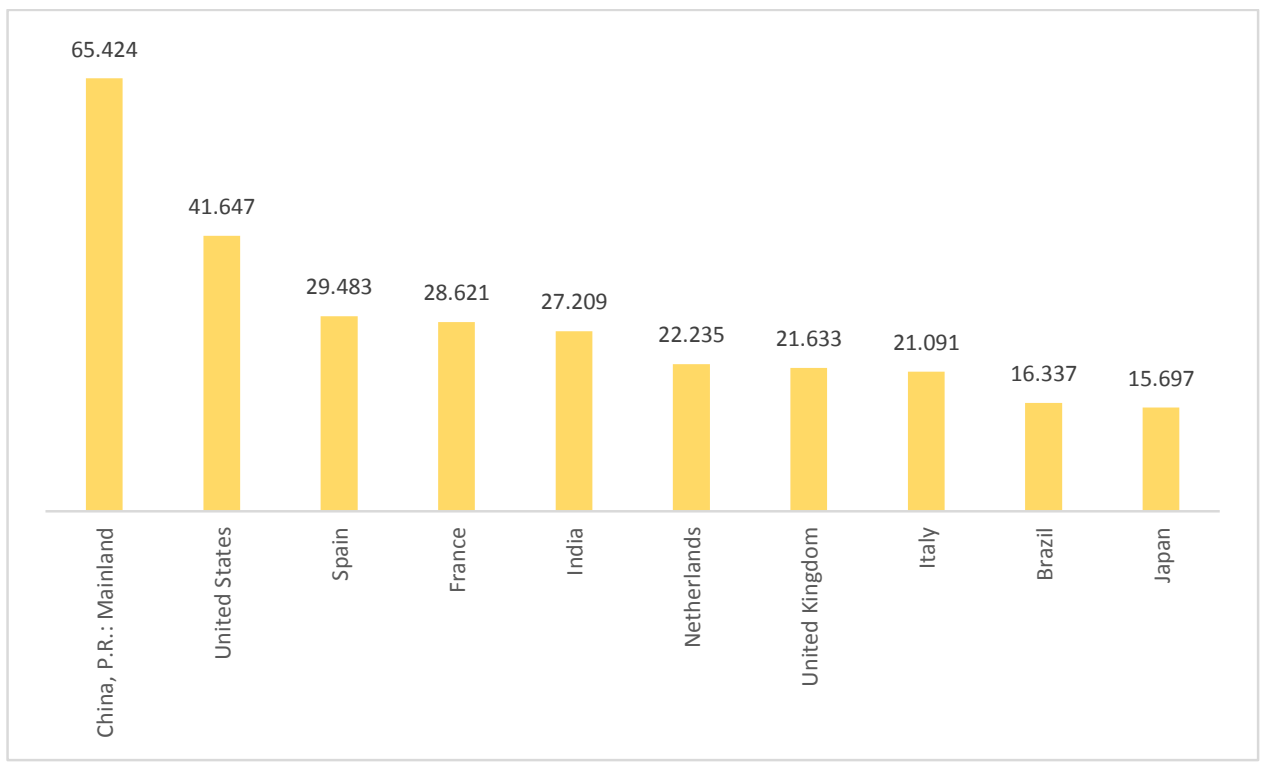

Fonte: Fundo Monetário Internacional: IMF Data Warehouse (2014)

Gráfico 35: Os principais países de origem de produtos comprados pela África (US\$ milhões/ 2013)

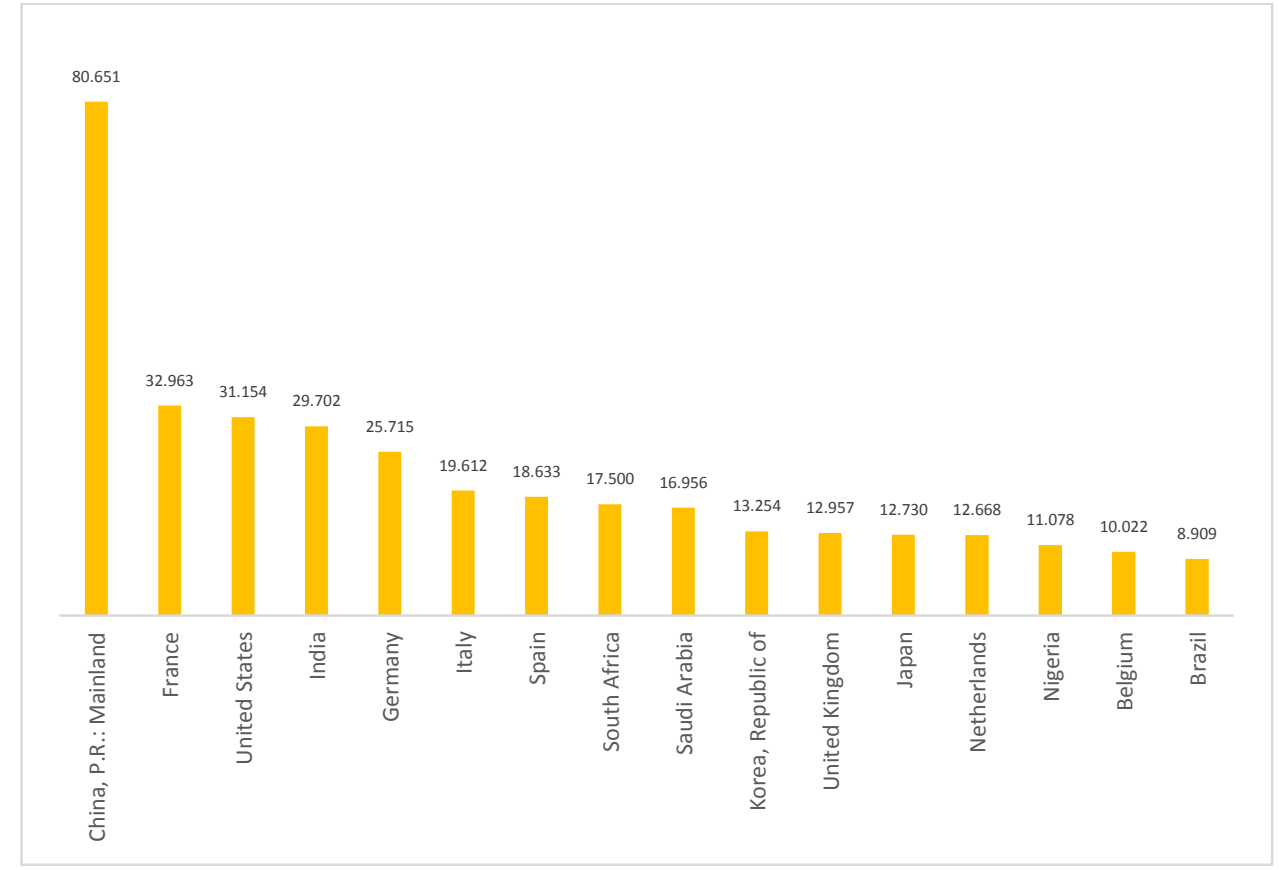

Fonte: Fundo Monetário Internacional: IMF Data Warehouse (2014)

O comércio da África com o mundo apresentou um incremento substancial, principalmente entre 1995 e 2008 . As exportações totais do continente cresceram em cerca de cinco vezes. Para Costa e Veiga (2011), o crescimento pode ser atribuído, em boa medida, ao 
aumento nos preços das commodities, que beneficiou fortemente os países exportadores de petróleo do continente, e à demanda crescente dos países emergentes, especialmente da China, e da própria África (COSTA; VEIGA, 2011, p. 25). O efeito do aumento nos preços das commodities também pode estar associado ao incremento do valor comercializado entre o Brasil e a África, dado o peso das commodities nas trocas nesse comércio, tanto nas exportações quanto nas importações.

Gráfico 36: Índice de preços de commodities* (1995-2014)

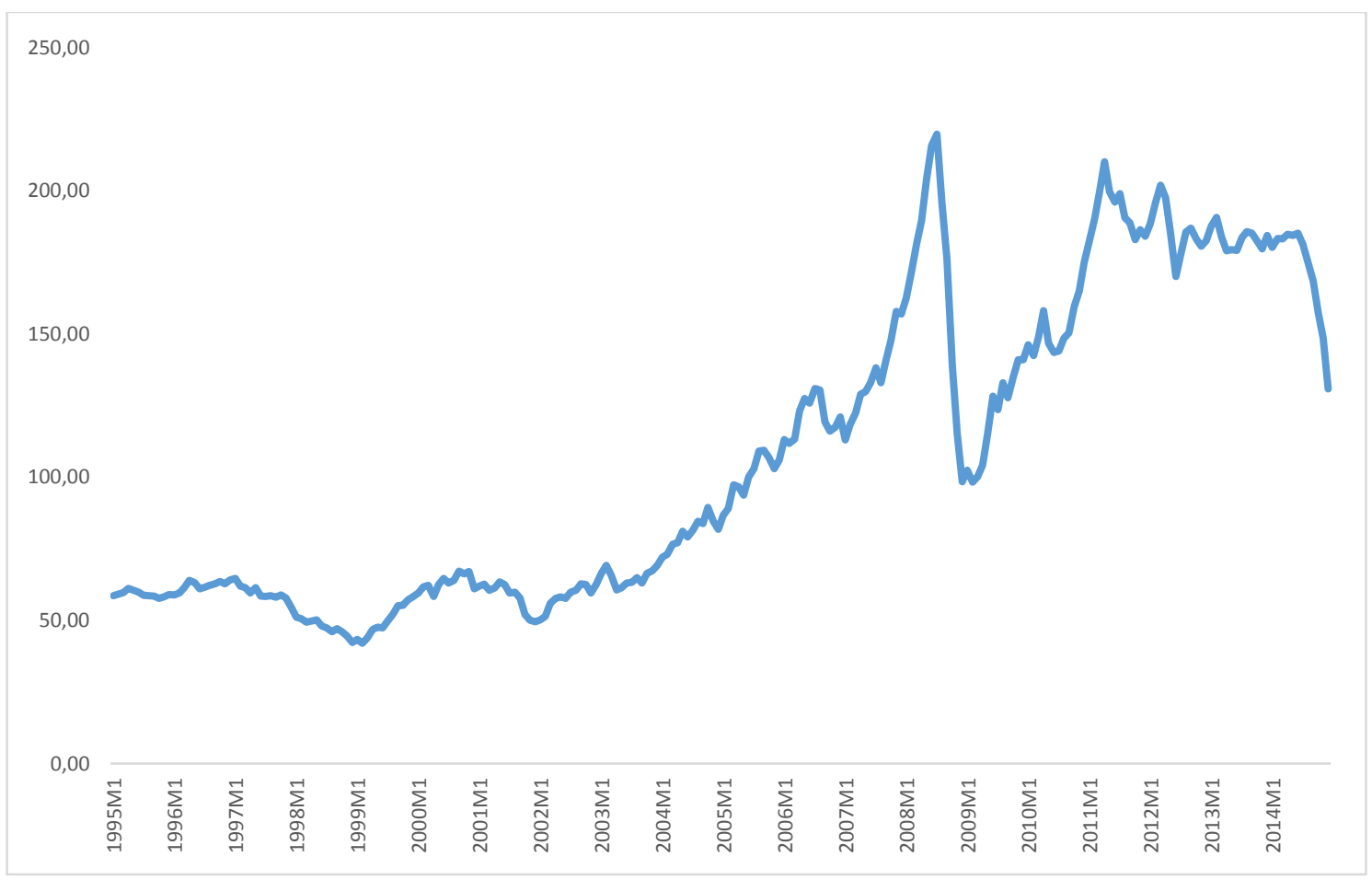

Fonte: Fundo Monetário Internacional (2015)

*All Commodity Price Index, 2005 = 100, includes both Fuel and Non-Fuel Price Indices.

A pauta de exportações, muito concentrada em commodities e com uma ascendente participação dos produtos básicos, configurou-se como outro ponto sensível das trocas comerciais brasileiras e africanas. É possível que o perfil do comércio tenha refletido a própria vocação do Brasil, que consolidou a posição de líder na produção e na exportação de extensa uma lista de produtos agrícolas. O país detém a posição de maior exportador mundial de açúcar, etanol, carne de frango, carne bovina, café, suco de laranja e tabaco, e é segundo maior exportador de soja, óleo de soja e farelo de soja. O Brasil também acumulou progressos em setores em que antes era importador, como algodão, milho, leite e maçã (JALES, 2005, p. 3). Araújo e Negri (2007), acreditam ser compreensível o desejo da sociedade na direção da busca pela inserção internacional em segmentos de maior conteúdo tecnológico, no qual as margens 
de ganho são maiores, os mercados são mais estáveis e os postos de trabalho são mais bem remunerados (ARAÚJO; NEGRI, 2007, p.51).

A análise do comércio exterior do Brasil com a África em dois períodos distintos, nos governos Fernando Henrique Cardoso e Luiz Inácio Lula da Silva, mostrou que o padrão das trocas comerciais pouco se alterou ao longo dos dezesseis anos em estudo. A despeito do acentuado aumento do valor comercializado, permanece a forte concentração geográfica de parceiros comerciais e a ênfase em uma pequena variedade de produtos. Além disso, é bastante significativa a presença dos produtos básicos e das commodities nos dois sentidos do comércio; no caso das importações da África, essa concentração se mostrou ainda maior. 


\section{OS INDICATIVOS DO COMÉRCIO EXTERIOR DO BRASIL COM A ÁFRICA NO PRIMEIRO MANDATO DE DILMA ROUSSEFF (2011-2014)}

A corrente de comércio entre o Brasil e a África, no primeiro mandato da presidenta Dilma Rousseff, bateu recorde histórico. A despeito de pequenas oscilações na série, o valor comercializado seguiu acima do melhor nível registrado durante o governo Lula e alcançou US\$28,5 bilhões, em 2013. Em 2014, as trocas comerciais equivaleram, em valores absolutos e em dólar, a quase dez vezes mais o que eram em 1995. O resultado, no entanto, se deveu ao aumento das importações feitas pelo Brasil na África, as exportações para o continente africano demonstraram uma tendência de queda a partir de 2011.

Tabela 36: O comércio com a África nos anos FHC, Lula e Rousseff (1995-2014)

\begin{tabular}{ccccc}
\hline & Exportação & Importação & Saldo & Corrente de Comércio \\
\hline Ano & US\$ FOB & US\$ FOB & US\$ FOB & US\$ FOB \\
\hline 1995 & 1.585 .821 .583 & 1.180 .637 .451 & 405.184 .132 & 2.766 .459 .034 \\
1996 & 1.527 .022 .348 & 1.690 .473 .093 & -163.450 .745 & 3.217 .495 .441 \\
1997 & 1.520 .000 .381 & 1.995 .198 .981 & -475.198 .600 & 3.515 .199 .362 \\
1998 & 1.651 .086 .046 & 1.819 .086 .788 & -168.000 .742 & 3.470 .172 .834 \\
1999 & 1.336 .476 .992 & 2.223 .842 .002 & -887.365 .010 & 3.560 .318 .994 \\
2000 & 1.347 .098 .183 & 2.907 .082 .676 & -1.559 .984 .493 & 4.254 .180 .859 \\
2001 & 1.989 .031 .346 & 3.330 .949 .802 & -1.341 .918 .456 & 5.319 .981 .148 \\
2002 & 2.363 .340 .654 & 2.675 .612 .821 & -312.272 .167 & 5.038 .953 .475 \\
2003 & 2.862 .003 .914 & 3.291 .174 .938 & -429.171 .024 & 6.153 .178 .852 \\
2004 & 4.247 .699 .268 & 6.183 .472 .779 & -1.935 .773 .511 & 10.431 .172 .047 \\
2005 & 5.981 .353 .507 & 6.656 .664 .579 & -675.311 .072 & 12.638 .018 .086 \\
2006 & 7.455 .879 .389 & 8.110 .811 .144 & -654.931 .755 & 15.566 .690 .533 \\
2007 & 8.578 .221 .741 & 11.346 .724 .972 & -2.768 .503 .231 & 19.924 .946 .713 \\
2008 & 10.169 .567 .120 & 15.761 .124 .122 & -5.591 .557 .002 & 25.930 .691 .242 \\
2009 & 8.692 .380 .077 & 8.465 .581 .857 & 226.798 .220 & 17.157 .961 .934 \\
2010 & 9.261 .599 .799 & 11.297 .251 .661 & -2.035 .651 .862 & 20.558 .851 .460 \\
2011 & 12.224 .792 .600 & 15.436 .247 .556 & -3.211 .454 .956 & 27.661 .040 .156 \\
2012 & 12.212 .624 .157 & 14.266 .074 .678 & -2.053 .450 .521 & 26.478 .698 .835 \\
2013 & 11.087 .040 .582 & 17.446 .394 .849 & -6.359 .354 .267 & 28.533 .435 .431 \\
2014 & 9.701 .013 .694 & 17.060 .825 .799 & -7.359 .812 .105 & 26.761 .838 .571 \\
\hline & & & &
\end{tabular}

Fonte: Elaboração própria a partir de dados do Aliceweb (BRASIL, 2014a). 
O valor das exportações caiu de US\$ 12, 2 bilhões, em 2011, para US\$ 9,7 bilhões, em 2014. Apesar disso, o valor exportado ainda é superior ao registrado no último ano do governo Lula. No entanto, o declínio pode indicar uma tendência de queda para os próximos anos. Outro indicativo relevante percebido na avaliação dos primeiros anos de mandato de Rousseff foi o aumento do déficit comercial com a África. Em 2014, o saldo negativo alcançou US\$ 7,3 bilhões.

Gráfico 37: A balança comercial do Brasil com a África (1989-2014)

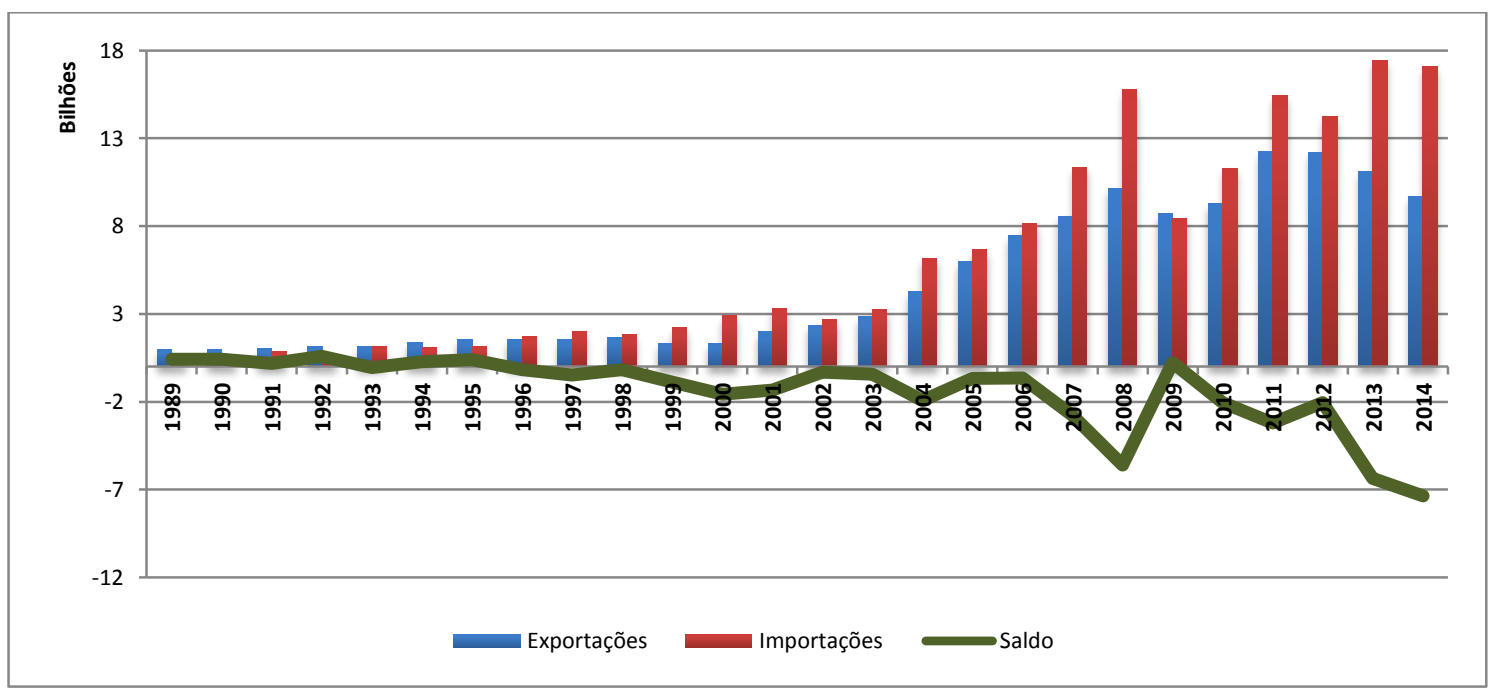

Fonte: Elaboração própria a partir de dados do Aliceweb (BRASIL, 2014a).

Houve oscilação também na participação do continente africano nas vendas de mercadorias do Brasil para o exterior. Ao final do governo Lula, o índice fechou em 4,59\%, e subiu nos dois primeiros anos de Rousseff para depois sofrer uma leve queda. Mesmo contabilizado o pequeno arrefecimento, o percentual de 4,31\% indica, no entanto, que o índice se manteve acima do registrado nos anos de Cardoso. Na análise da participação das importações feitas pelo Brasil com origem no continente africano, notou-se uma forte queda em 2009, ainda durante o governo Lula. Depois disso, e mesmo durante os anos de Rousseff, o percentual oscilou pouco com uma leve tendência de crescimento. 
Gráfico 38: Participação das exportações para África no total das exportações do Brasil (19952014)

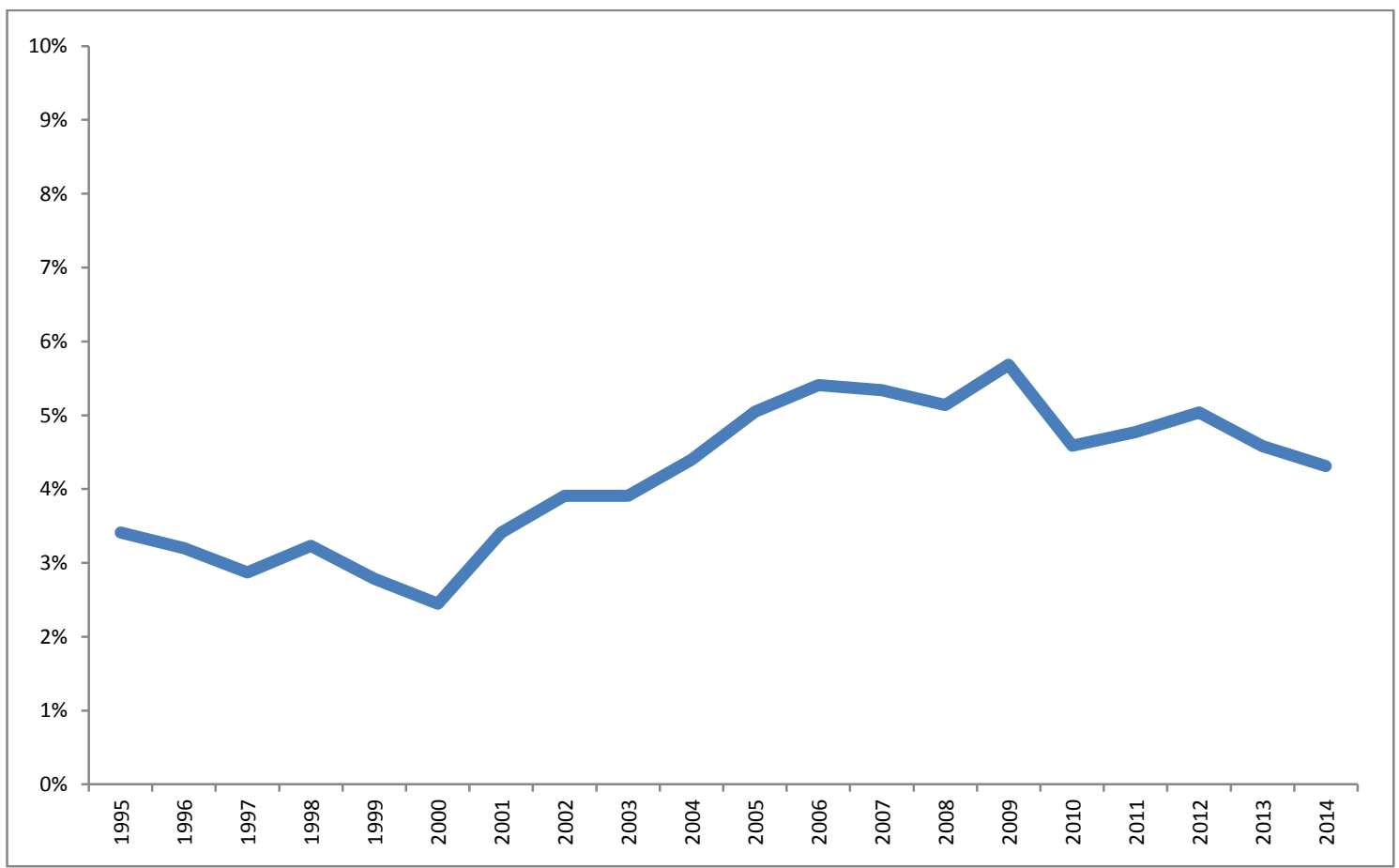

Fonte: Elaboração própria a partir de dados do Aliceweb (BRASIL, 2014a).

Gráfico 39: Participação das importações feitas da África no total das importações do Brasil (1995-2014)

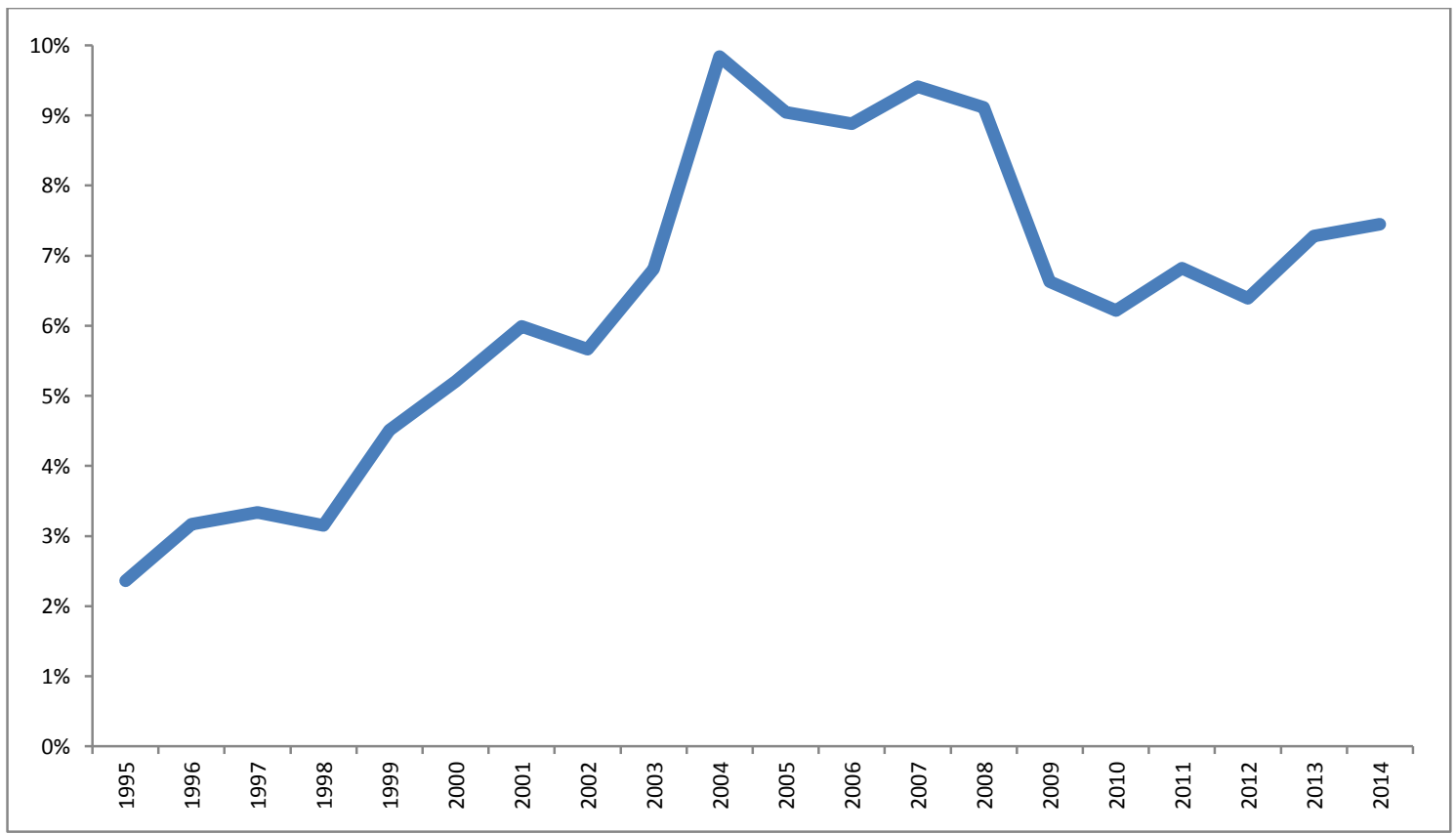

Fonte: Elaboração própria a partir de dados do Aliceweb (BRASIL, 2014a). 
A análise do tipo de produtos comercializados durante o governo Rousseff revelou ainda uma piora mais acentuada no perfil das mercadorias vendidas, tendência que começou com FHC e cresceu nos governos Lula. Os produtos exportados para a África classificados como básicos eram 17,86\%, ao final dos anos FHC; mais tarde cresceram para 31,58\%, em 2010; e passaram para 35,16\%, em 2014.

Tabela 37: Perfil das exportações do Brasil para a África (1995-2014)

\begin{tabular}{ccccc}
\hline & Básicos & Semimanufaturados & Manufaturados & Op. Especiais \\
\hline 1995 & $9,15 \%$ & $34,45 \%$ & $56,17 \%$ & $0,23 \%$ \\
1996 & $11,04 \%$ & $29,75 \%$ & $58,81 \%$ & $0,41 \%$ \\
1997 & $15,41 \%$ & $20,18 \%$ & $63,99 \%$ & $0,41 \%$ \\
1998 & $14,73 \%$ & $19,35 \%$ & $65,65 \%$ & $0,27 \%$ \\
1999 & $15,03 \%$ & $15,37 \%$ & $69,18 \%$ & $0,43 \%$ \\
2000 & $18,50 \%$ & $12,27 \%$ & $68,75 \%$ & $0,48 \%$ \\
2001 & $18,23 \%$ & $14,25 \%$ & $67,30 \%$ & $0,23 \%$ \\
2002 & $17,86 \%$ & $13,85 \%$ & $68,10 \%$ & $0,19 \%$ \\
2003 & $18,58 \%$ & $14,22 \%$ & $67,00 \%$ & $0,20 \%$ \\
2004 & $23,94 \%$ & $13,99 \%$ & $61,93 \%$ & $0,14 \%$ \\
2005 & $21,61 \%$ & $14,96 \%$ & $63,35 \%$ & $0,08 \%$ \\
2006 & $19,69 \%$ & $17,18 \%$ & $63,05 \%$ & $0,08 \%$ \\
2007 & $18,46 \%$ & $12,56 \%$ & $68,86 \%$ & $0,12 \%$ \\
2008 & $22,12 \%$ & $13,16 \%$ & $64,63 \%$ & $0,09 \%$ \\
2009 & $25,28 \%$ & $16,93 \%$ & $57,66 \%$ & $0,13 \%$ \\
2010 & $31,58 \%$ & $21,16 \%$ & $47,15 \%$ & $0,11 \%$ \\
2011 & $30,68 \%$ & $27,40 \%$ & $41,78 \%$ & $0,14 \%$ \\
2012 & $35,65 \%$ & $25,67 \%$ & $38,53 \%$ & $0,15 \%$ \\
2013 & $33,87 \%$ & $24,67 \%$ & $41,27 \%$ & $0,18 \%$ \\
2014 & $35,16 \%$ & $22,64 \%$ & $41,94 \%$ & $0,25 \%$ \\
\hline
\end{tabular}

Fonte: Elaboração própria a partir de dados do Aliceweb (BRASIL, 2014a).

Observada a série histórica dos percentuais de produtos manufaturados, semimanufaturados e básicos, ficou evidente a deterioração da qualidade da pauta de produtos exportados para a África. Em 1999, o equivalente a 68,18\% de tudo que era exportado para a África era manufaturado. O percentual despencou ao longo dos anos e fechou $2014 \mathrm{em} \mathrm{41,94 \% .}$ Com isso, as mercadorias classificadas como básicas ultrapassaram a proporção de um terço das exportações. 
Gráfico 40: Perfil das exportações do Brasil para a África (1995-2014)

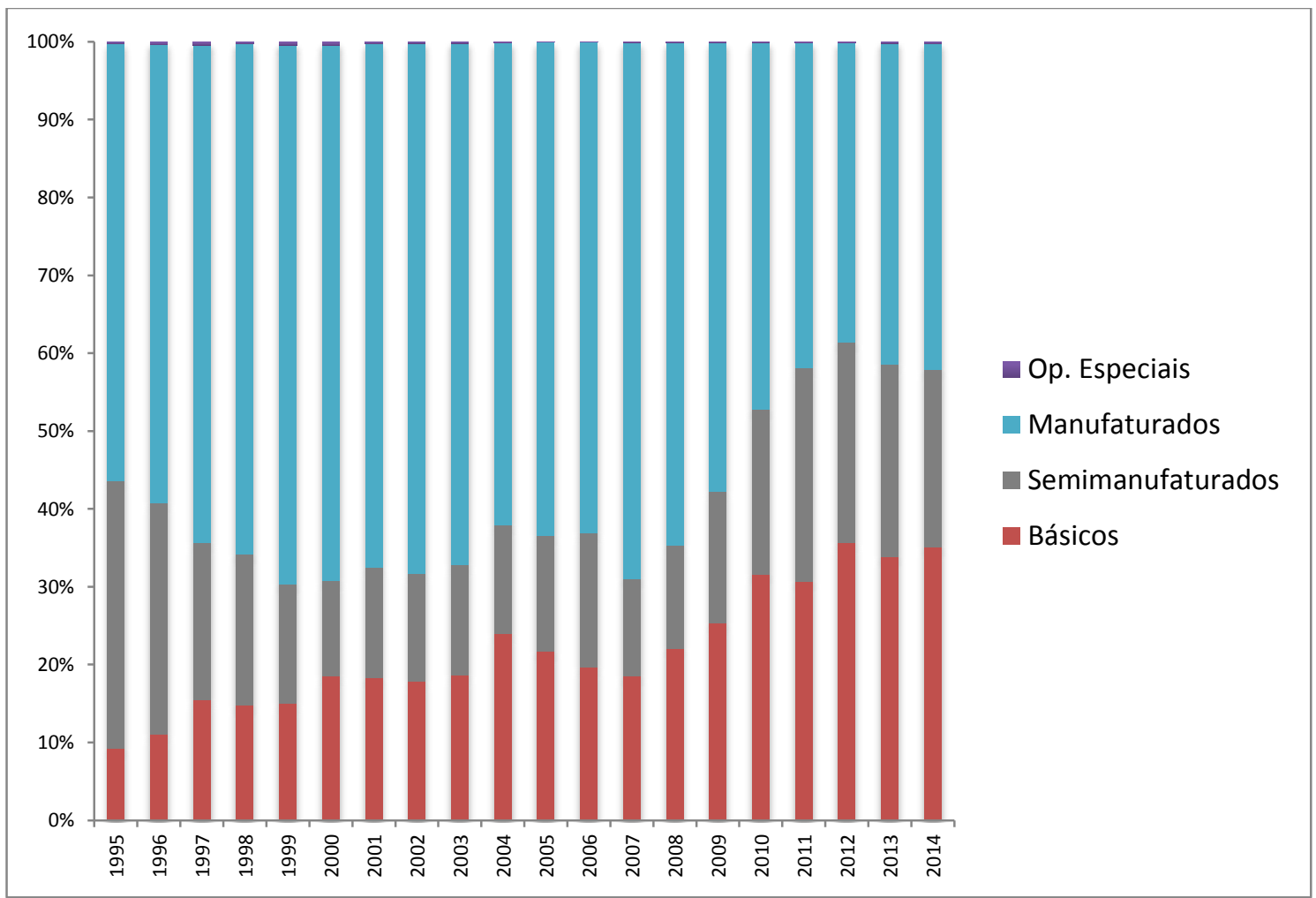

Fonte: Elaboração própria a partir de dados do Aliceweb (BRASIL, 2014a).

Em uma ação parecida com a de seu antecessor, Dilma Rousseff, anunciou o cancelamento de US\$ 840 milhões em dívidas de doze países africanos durante a comemoração dos cinquenta anos da União Africana, em 2013. O perdão dos débitos foi apresentado como uma tentativa de estreitar os laços econômicos com o continente. Rousseff argumentou que o sentido da negociação era o de reestabelecer as relações com esses países, tanto do ponto de vista de investimento quanto de relações comerciais. A liquidação das dívidas, ela defendeu, criaria uma via de mão dupla ao beneficiar o continente africano e também o Brasil (BBC BRASIL, 2013).

O governo argumentou que os acordos possibilitavam reaver parte dos recursos considerados de difícil recuperação e contribuiriam com os esforços da comunidade internacional na renegociação ou no perdão de dívidas dos países pobres altamente endividados. A renegociação permitiria também a regularização do relacionamento financeiro entre os países, abrindo novas possibilidades para uma retomada das relações econômicas e comerciais. 
Tabela 38: Descrição das dívidas da África com o Brasil negociadas pela presidente Dilma Rousseff (2011-2014)

\begin{tabular}{|c|c|}
\hline Países & Decorrência dos débitos \\
\hline $\begin{array}{l}\text { República da Costa do Marfim } \\
\text { República Gabonesa (Gabão) } \\
\text { República de Guiné (Conacri) } \\
\text { República de Guiné-Bissau } \\
\text { República Islâmica da Mauritânia } \\
\text { República Unida da Tanzânia } \\
\text { República da Zâmbia }\end{array}$ & $\begin{array}{l}\text { Dívidas oficiais dos países originadas de financiamentos à exportação } \\
\text { concedidos pela União, com prazo superior a } 1 \text { (um) ano, por meio de } \\
\text { Convênios de Crédito celebrados entre o Banco do Brasil S.A. - Carteira de } \\
\text { Comércio Exterior (CACEX) e os governos desses países, ou garantidos pelos } \\
\text { mesmos, realizados com recursos do então Fundo de Financiamento à } \\
\text { Exportação (FINEX), hoje extinto, cujos créditos passaram a ser geridos pelo } \\
\text { Programa de Financiamento às Exportações (PROEX). }\end{array}$ \\
\hline $\begin{array}{l}\text { República do Congo (Brazzaville) } \\
\text { República do Senegal } \\
\text { República do Sudão }\end{array}$ & $\begin{array}{l}\text { Dívidas oficiais dos países originadas de financiamentos à exportação } \\
\text { concedidos pela União com prazo superior a } 1 \text { (um) ano por meio de Convênios } \\
\text { de Crédito celebrados entre o Banco do Brasil - S.A. - Carteira de Comércio } \\
\text { Exterior (CACEX) e os governos desses países, ou garantidos pelos mesmos, } \\
\text { realizados com recursos do então Fundo de Financiamento à Exportação } \\
\text { (FINEX), hoje extinto, cujos créditos passaram a ser geridos pelo Programa de } \\
\text { Financiamento às Exportações (PROEX). Essas operações, contavam ainda } \\
\text { com garantia do Seguro de Crédito à Exportação do Instituto de Resseguros do } \\
\text { Brasil S.A. (IRB), denominado, em 1997, IRB-Brasil Resseguros S.A., que se } \\
\text { sub-rogou, em parte desses créditos pendentes (non-performing), em } \\
\text { decorrência de indenização securitária. }\end{array}$ \\
\hline República Democrática do Congo & $\begin{array}{l}\text { Dívida originada de financiamento à exportação concedido pela União, com } \\
\text { prazo inferior a } 1 \text { (um) ano por meio de Convênio de Crédito celebrado entre o } \\
\text { Banco do Brasil S.A. - Carteira de Comércio Exterior (CACEX) e o governo } \\
\text { desse país, realizado com recursos do então Fundo de Financiamento à } \\
\text { Exportação (FINEX), hoje extinto, cujos créditos passaram a ser geridos pelo } \\
\text { Programa de Financiamento às Exportações (PROEX). Essa operação contava, } \\
\text { ainda, com garantia do Seguro de Crédito à Exportação do Instituto de } \\
\text { Resseguros do Brasil, denominado, em 1997, IRB-Brasil Resseguros S.A., que } \\
\text { se sub-rogou, em parte, desses créditos pendentes (non-performing), em } \\
\text { decorrência de indenização securitária. }\end{array}$ \\
\hline $\begin{array}{l}\text { República Democrática de São Tomé e } \\
\text { Príncipe }\end{array}$ & $\begin{array}{l}\text { Dívida oficial originada de crédito aprovado pela Câmara de Comércio Exterior } \\
\text { (CAMEX) em } 23 \text { de outubro de } 2007 \text {. Esse crédito foi concedido com recursos } \\
\text { do PROEX/Financiamento para a aquisição de alimentos e outros produtos } \\
\text { essenciais produzidos no Brasil. }\end{array}$ \\
\hline
\end{tabular}

Fonte: BRASIL, 2013b

O anúncio feito pela presidenta Dilma Rousseff prevê perdão de parte das dívidas e também o reescalonamento de valores. A porcentagem perdoada alcançou até $90 \%$ de débitos, caso da dívida do Sudão. Dos doze países alvo das negociações, os projetos de reescalonamento de cinco (República do Congo, Sudão, Gabão, Senegal, São Tomé e Príncipe) receberam 
aprovação do Senado Federal, tornando-se norma jurídica em vigor. Os projetos de resolução de outros quatro (República Democrática do Congo, Costa do Marfim, Zâmbia e Tanzânia) ainda aguardavam a entrada na pauta da Comissão de Assuntos Econômicos do Senado Federal para serem votadas, no início de 2014. As mensagens presidenciais das dívidas da Mauritânia, Guiné-Bissau e Guiné tinham sido ainda encaminhadas ao Senado Federal, segundo a Casa Civil, porque os termos do acordo ainda estavam em negociação com as diplomacias dos países. Por conta disso, portanto, as resoluções sobre essas dívidas ainda não tinham chegado ao Congresso Nacional.

Tabela 39: Descrição de valores de dívida, perdão e reescalomento de dívidas com o Brasil / Dilma Rousseff (2011-2014)

\begin{tabular}{|c|c|c|c|c|}
\hline País & $\begin{array}{l}\text { Total da dívida } \\
\text { (US\$) }\end{array}$ & $\begin{array}{c}\text { Perdão / } \\
\text { Remissão } \\
(\%)\end{array}$ & $\begin{array}{c}\text { Dívida } \\
\text { Perdoada } \\
\text { (US\$) }\end{array}$ & $\begin{array}{c}\text { Valor } \\
\text { reescalonado } \\
\text { (US\$) }\end{array}$ \\
\hline República do Congo & $352,676,103.62$ & $79 \%$ & $\begin{array}{r}278,087,640.6 \\
4 \\
\end{array}$ & $74,588,462.98$ \\
\hline República Unida da Tanzânia & $236,996,036.19$ & $86 \%$ & $\begin{array}{r}203,609,713.6 \\
5 \\
\end{array}$ & $33,386,322.54$ \\
\hline República da Zâmbia & $113,423,004.53$ & $80 \%$ & $90,738,403.62$ & $22,684,600.91$ \\
\hline República do Sudão & $43,581,141.68$ & $90 \%$ & $39,223,027.52$ & $4,358,114.16$ \\
\hline República do Gabão & $27,654,760.40$ & $13 \%$ & $3,569,644.62$ & $24,085,115.78$ \\
\hline República da Costa do Marfim & $9,045,635.40$ & $86 \%$ & $7,782,778.80$ & $1,262,856.60$ \\
\hline República do Senegal & $6,569,351.22$ & $45 \%$ & $2,969,804.75$ & $3,599,546.47$ \\
\hline República Democrática do Congo (RDC) & $4,761,470.98$ & $54 \%$ & $2,555,661.61$ & $1,596,929.53$ \\
\hline $\begin{array}{l}\text { República Democrática de São Tomé e } \\
\text { Príncipe }\end{array}$ & $4,323,293.85$ & $0 \%$ & 0.00 & $4,323,293.85$ \\
\hline República Islâmica da Mauritânia & \multicolumn{4}{|c|}{ Detalhes ainda em negociação. } \\
\hline República de Guiné-Bissau & \multicolumn{4}{|c|}{ Detalhes ainda em negociação. } \\
\hline República da Guiné & \multicolumn{4}{|c|}{ Detalhes ainda em negociação. } \\
\hline
\end{tabular}

Fonte: Elaboração própria a partir da leitura dos pareceres disponíveis no site do Senado Federal. As dívidas da Mauritânia, Guiné-Bissau e Guiné ainda estão em negociação com a diplomacia desses países, segundo a Casa Civil da Presidência da República. Consulta feita à assessoria jurídica da Casa Civil.

A ação solidária da atual diplomacia brasileira rendeu críticas da oposição ao governo no Congresso Nacional e levantou uma série de questionamentos sobre a viabilidade de conceder crédito para exportação de mercadorias brasileiras, sem garantia de que os valores serão pagos. No caso do perdão da dívida da República do Congo, Congo Brazzaville, o senador Aloysio Nunes Ferreira (PSDB/SP), argumentou que o Brasil deveria ter levado em conta o fato de o país, segundo ele, ser governado por uma elite corrupta. No mesmo sentido, o senador Álvaro Dias (PSDB/PR) lamentou que o Brasil esteja apoiando regimes, considerados por ele, como ditatoriais e que esmagam a sua população. Dias afirma que o perdão das dívidas tem 
ainda uma finalidade financeiro-político, uma vez que o objetivo da atitude brasileira seria o de "abrir a perspectiva de o Banco Nacional de Desenvolvimento Econômico e Social (BNDES) continuar oferecendo novos empréstimos a esses países (VALOR ECONÔMICO, 2013).

Ainda será preciso mais tempo de observação e um estudo mais aprofundado para avaliar o resultado das negociações das dívidas da África no comércio exterior brasileiro. Não ficou claro se o perdão de débitos, originários de pagamentos de compras de mercadorias brasileiras não pagas, terá impacto e resultará em uma maior aproximação comercial do Brasil com a África. O que se pode indicar até aqui, diante da análise dos quatro primeiros anos de mandato de Rousseff, é que a exportação brasileira para o continente africano deu sinais de ter tomado uma trajetória cadente. As importações, por outro lado, seguiram em ritmo de crescimento, o que ampliou o déficit comercial do Brasil com a África. 


\section{CONCLUSÕES}

A análise das trocas comerciais do Brasil com a África revelou que os valores negociados sofreram pouca oscilação durante os anos de governo de Fernando Henrique Cardoso, momento que coincidiu com uma fase de abrandamento das relações exteriores entre os dois lados do Atlântico. Os anos de Cardoso caracterizaram-se por um abandono relativo da tradicional política africana construída pelo Brasil durante décadas. A situação dos países africanos, muitos deles enfrentavam crise econômica e institucional, também ajudou a justificar o estado sereno do relacionamento. Houve ainda um certo retraimento da presença brasileira na África, motivado principalmente, pelas dificuldades de boa parte daqueles países e pelas prioridades dadas pela chancelaria brasileira naqueles anos. A diplomacia presidencial de FHC foi pouco presente no continente. Cardoso visitou a África em apenas três oportunidades. Apesar do abrandamento das relações, FHC e a diplomacia coletiva do Mercosul fecharam um acordo com a África do Sul para formação de uma zona de livre comércio. Mais tarde, durante o governo de Luiz Inácio Lula da Silva, as negociações evoluíram para envolver a união aduaneira formada pela África do Sul, Namíbia, Botsuana, Lesoto e Suazilândia. Um acordo de preferências tarifárias foi assinado em 2008-2009, mas que não entrou em vigor até 2014.

Diferentemente dos anos de retraimento das relações com a África no governo FHC, os dois mandatos de Lula foram responsáveis por uma retomada vigorosa da aproximação do Brasil com o continente africano. Com Lula na presidência, a política africana do Brasil ganhou intensidade, o que refletiu os ajustes de agenda (adjustment changes) promovidos pelos governos brasileiros com esses países, desde o fim da Guerra Fria. Em oito anos de mandato, Lula visitou vinte e dois países africanos, constantemente acompanhado por uma comitiva de empresários brasileiros. Foi dado um impulso em direção à África. Inclusive os países governados por ditadores foram cortejados pela diplomacia de Lula, expondo o Brasil às vezes a situações constrangedoras. Entre aqueles procurados por Lula para aproximar os laços diplomáticos, estava a Guiné Equatorial, de Obiang Nguema, então com mais de trinta anos de poder, iniciados com um golpe de Estado.

Para além das relações diplomáticas, o relacionamento comercial do Brasil com a África também cresceu excepcionalmente a partir do governo Lula. A importância do mercado africano no comércio brasileiro com o mundo cresceu. A corrente de comércio alcançou US\$ 25,9 bilhões, em 2008, o mais alto valor no governo Lula e depois US $\$ 28,5$ bilhões, no primeiro mandato de Dilma Rousseff. A soma de exportações e importações era de US\$ 5,03 bilhões no 
último ano do governo FHC, o que mostra um crescimento de mais de $400 \%$ da corrente nos anos Lula. As importações e as exportações cresceram no período, com exceção de 2009, ano do ápice da crise financeira internacional, e houve uma retomada do crescimento nos anos seguintes. No primeiro mandato da presidente Dilma Rousseff, no entanto, o valor exportado registrou queda e as importações cresceram, o que ajudou a elevar o déficit comercial com a África.

A participação do continente africano na cesta de exportações brasileiras cresceu relativamente nos anos de governo do Partido dos Trabalhadores. $\mathrm{O}$ índice tomou uma curva ascendente e atingiu 5,68\%, em 2009. Logo depois houve um recuo, mas sem que a participação voltasse ao nível anterior. O valor das exportações passou de US\$ 2,8 bilhões, em 2003, para US\$ 9,2 bilhões, em 2010. O avanço registrado foi de 223,61\%, bem acima do percentual de crescimento do total das exportações brasileiras, que avançaram $175 \%$ no período. E, ainda que o percentual de participação da África nas exportações tenha apresentado queda nos primeiros anos de mandato de Dilma Rousseff, permaneceu acima do nível dos anos FHC. O peso da África nas importações brasileiras, que vinha em crescimento desde os anos Cardoso, tomou novo e vigoroso fôlego, chegando perto de atingir $10 \%$ do total das importações do Brasil, em 2004.

O aumento do valor comercializado entre os parceiros, no entanto, veio acompanhado da piora no perfil das mercadorias vendidas. A proporção dos básicos começou a aumentar durante o governo FHC, passando de $9,15 \%$ para $17,86 \%$. Nos anos Lula, o percentual foi de 18,58\% para $31,58 \%$. No primeiro mandato da presidente Dilma Rousseff, o índice subiu novamente e terminou 2014 em 35,16\%. Mesmo assim, os produtos com valor agregado, somados os manufaturados e semimanufaturados, ainda preservaram a maior parte das exportações para o continente africano. Os números apontam que o Brasil tem exportado para a África cada vez mais produtos básicos, que consistem em mercadorias com baixo valor agregado com cadeias produtivas geralmente pouco complexas.

A análise dos produtos vendidos para a África mostra uma forte concentração de açúcar de cana em bruto, e outros açúcares de cana, beterraba e sacarose quimicamente pura, e minérios de ferro aglomerados e concentrados, nos períodos analisados. Nos anos Lula, gasolina e carnes desossadas apareceram também entre os cinco produtos mais vendidos para os africanos.

A piora do perfil dos produtos exportados é uma particularidade da balança comercial brasileira como um todo, não apenas com a África, característica que se acentuou na gestão Lula. A mudança é uma quebra preocupante no padrão de comércio que começou a ser 
construído com o esforço do paradigma desenvolvimentista. A alteração do perfil da balança comercial preocupa porque pode causar desindustrialização e um fenômeno de maior dependência tecnológica ao país, que perde em competitividade internacional.

$\mathrm{Na}$ corrente de comércio com a África, houve um significativo aumento do peso no fluxo de commodities. Durante o governo Fernando Henrique Cardos, essas mercadorias, como açúcar de cana, minério de ferro e óleo de soja em bruto, totalizaram 56,90\% de todo o valor exportado para a África. Durante o governo de Luiz Inácio Lula da Silva, o índice ficou bem próximo, 53,45\% das vendas para a África consistiam em commodities.

O perfil dos produtos importados do continente africano não foi muito diferente. No governo FHC, perto da metade do total exportado, $48,85 \%$, consistia em produtos básicos e $46,01 \%$ eram commodities. Houve um forte incremento das commodities importadas da África especialmente nos anos Lula, quando as compras desse tipo de mercadoria cresceram para $76,21 \%$. Os números demonstram que o aumento das compras do Brasil em território africano se deu principalmente em razão do comércio de petróleo e derivados.

A concentração geográfica da balança comercial Brasil-África em poucos países foi outra característica comum constatada no estudo dos anos FHC e Lula. Durante os oito anos de Cardoso na presidência, quatro países africanos estiveram na liderança como principais mercados para as exportações do Brasil. Egito, África do Sul, Nigéria e Marrocos aparecem no topo da lista de países que mais compraram produtos brasileiros entre 1995 e 2002. Sozinhos, os quatro representaram $67,78 \%$ do total das exportações do Brasil para a África ao longo dos anos em estudo. Argélia e Angola alternaram-se na posição de quinto principal destino das mercadorias brasileiras na África, nos anos FHC. Os seis países juntos representaram 77,50\% das exportações para a África no período.

Argélia, Nigéria, África do Sul, Marrocos e Angola apareceram ainda no topo da lista dos principais fornecedores do Brasil na África, de 1995 a 2002. Os cinco países concentraram $88,87 \%$ do valor total importado pelo mercado brasileiro. A concentração geográfica na análise das importações é ainda mais significativa do que a constatada nas exportações. Sozinha, a Argélia deteve 38,65\% do total das importações feitas pelo Brasil na África, entre 1995 e 2002. Somado o percentual da Nigéria, o índice saltou para 70,15\%.

No governo Lula, a concentração de parceiros comerciais apresentou-se, mais uma vez, bastante evidente. África do Sul, Nigéria, Egito e Angola se revezaram nos primeiros lugares do ranking de principais destinos. Os quatro detiveram $62,45 \% \%$ do valor exportado; incluído o quinto colocado, Argélia, o percentual alcançou 69,49\%; com Marrocos, os seis primeiros 
contabilizaram $75,73 \% \%$. A África do Sul foi o principal destino das mercadorias brasileiras na África em cinco dos oito anos de mandato Lula. No período FHC, o país ocupou a posição durante três anos apenas. Angola, que nos anos de Cardoso, surgiu como quinto ou sexto colocado, em alguns momentos; durante o governo Lula, chegou a ocupar o primeiro lugar, em 2008. E Egito, quatro vezes principal destino das mercadorias brasileiras na África, nos anos Cardoso, esteve em primeiro em apenas duas oportunidades no período entre 2003 e 2010 . Entre os que mais fornecem mercadorias para o Brasil, Argélia e Nigéria polarizam as importações com um percentual de $71,16 \%$ do total comprado da África pelo Brasil. Sozinha, a Nigéria representou 48,16\% do valor importado entre 2003 e 2010. Angola, Marrocos, Líbia e África do Sul foram os outros mais bem colocados, os seis juntos acumularam 92,99\% das importações.

A avaliação das vendas para os seis principais países compradores de mercadorias brasileiras na África, entre 2003 e 2010, mostrou Angola como o destino do menor percentual de commodities, 20,93\%; no governo FHC, o índice era de 27,88\%. Angola comprou o maior peso de mercadorias manufaturados, $85,39 \%$, nos anos entre 2003 e 2010 ; entre 1997 e 2002, o percentual era de $80,96 \%$. A África do Sul, que tinha o menor índice de commodities nos anos de governo de Cardoso, aumentou o peso desse tipo de produto nas exportações, o percentual passou de $18,06 \%$ para $24,79 \%$. Houve um leve recuo também no índice de manufaturados, era $79,71 \%$ e ficou em 77,14, nos anos de Lula. As características gerais das exportações para os outros quatro países de destaque, Argélia, Egito, Marrocos e Nigéria, se mostraram bem próximas daquelas percebidas no comércio dos anos Cardoso: um significativo peso das commodities na cesta de produtos.

No estudo dos produtos importados pelo Brasil, notou-se uma expressiva ênfase de petróleo e derivados. Da Nigéria, 99,72\% do valor comprado pelo mercado brasileiro se referiam a óleos brutos de petróleo, naftas para petroquímica, gás natural liquefeito, gás liquefeito de petróleo (GLP), butanos liquefeitos, outros propanos liquefeitos e outras naftas. $\mathrm{Na}$ análise da pauta de importações da Argélia, a situação foi parecida. Do que veio da Argélia, 98,24\% eram óleos brutos de petróleo, naftas para petroquímica, outros propanos liquefeitos e outras naftas. O peso de petróleo e derivados apareceu também como principal característica da pauta de importações da África como um todo. Apenas os óleos brutos de petróleo, produto classificado como básico, representaram 75,50\% de tudo o que foi importado de 2003 a 2010. O percentual representou um salto em relação ao registrado nos anos Cardoso, quando esse percentual era de $40,34 \%$. 
Durante o governo de Fernando Henrique, o Brasil passou a registrar déficits na balança comercial com a África. Antes de FHC na presidência, entre 1989 e 1995, foram seis anos de superávit e apenas um, em 1993, quando o comércio fechou com resultado negativo para o Brasil. A partir de 1996, o superávit se transformou em déficit e seguiu assim durante a maior parte do governo de Lula, com o agravante de que, nos anos de governo do PT, o valor do déficit comercial se acentuou consideravelmente, inclusive no governo de Rousseff. Nos anos FHC, o resultado deficitário do comércio Brasil-África repetia o desempenho da balança comercial brasileira como um todo. Nos anos Lula, o déficit com a África foi uma contradição com os crescentes e robustos superávits registrados na balança comercial brasileira com o mundo. Com FHC, o pior déficit com a África foi de US\$ 1,5 bilhões; no governo Lula, o valor chegou a US\$ 5,5 bilhões. No último ano do primeiro mandato de Rousseff, a diferença entre exportações e importações alcançou resultado negativo de US\$ 7,3 bilhões.

$\mathrm{Na}$ análise da balança com os principais parceiros comerciais do Brasil na África, durante o governo FHC, a conta se mostrou favorável a este lado do Atlântico no comércio com Egito e Marrocos. No caso de Angola, houve certa irregularidade, com oscilações entre superávits e déficits. Para a África do Sul, os resultados negativos registrados de 1995 a 1998 se tornaram superávits crescentes. As trocas comerciais com os mercados de Argélia e Nigéria registraram os maiores déficits. Considerado o período Lula, foram contabilizados resultados superavitários com África do Sul e Egito. Com Angola e Marrocos, o resultado foi positivo na maior parte do tempo; as únicas exceções foram um ano de déficit com os angolanos e dois anos com os marroquinos. Os déficits constantes e crescentes registrados entre 2003 e 2010 foram com Argélia e Nigéria.

Uma controversa iniciativa brasileira nas relações com a África foi o perdão e o reescalonamento de dívidas de países do continente. O levantamento apresentado neste trabalho mostrou que todos os débitos se referiam a vendas de mercadorias brasileiras para a África. Houve renegociações com países africanos desde o governo Fernando Henrique. As concessões evoluíram da inicial remissão de juros de mora e dilatação de prazos originais de amortização à concessão parcial de perdão a valor devido. Alguns países beneficiados com reestruturação, perdão ou reescalonamento de dívida nos anos de governo de Fernando Henrique Cardoso foram novamente alvo de renegociações nas gestões de Lula e Dilma Rousseff. Não foi possível averiguar, no entanto, se os valores se referiam às mesmas dívidas, uma vez que os pareceres apresentados pela Presidência da República ao Congresso Nacional, responsável por votar os pedidos, não evidenciaram isso. 
O governo Cardoso negociou dívidas com oito países africanos: Costa do Marfim, Moçambique, Mauritânia, Zâmbia, Gana, Gabão, Tanzânia e Cabo Verde. O presidente Lula propôs o reescalonamento de dívidas de três: Cabo Verde, Moçambique e Nigéria, um grande produtor e exportador de petróleo, o que levanta dúvidas sobre a real necessidade da ação benevolente brasileira na África. Em visita ao continente africano, em maio 2013, durante a comemoração dos cinquenta anos da União Africana, a presidente Dilma Rousseff anunciou o cancelamento de dívidas de doze países: Costa do Marfim, Gabão, Guiné (Conacri), GuinéBissau, Mauritânia, Tanzânia, Zâmbia, Congo (Brazzaville), Senegal, Sudão, República Democrática do Congo (Kinshasa) e São Tomé e Príncipe. A questão das dívidas perdoadas exigirá no futuro um estudo mais aprofundado e minucioso. O efeito político da simpatia brasileira com a dívida africana pode se refletir em dividendos difíceis de serem mensurados, como foi o decisivo apoio dos países da África na eleição do diplomata brasileira Roberto Azevêdo para a direção-geral da Organização Mundial do Comércio, em 2013.

Finalmente, são inúmeras as oportunidades para o Brasil na África. Dos 54 países africanos, apenas seis concentram mais de $70 \%$ do valor exportado para o continente. O Brasil tem condições de conquistar o mercado dos países com os quais tem uma balança comercial deficitária, especialmente Nigéria e Argélia. Ademais, a infraestrutura marítima apresenta-se como favorável para a exploração dos potenciais desse mercado. Há pouco mais de uma década inexistentes, as rotas marítimas diretas, que atravessam o Atlântico sem escala em grandes portos da Europa, são frequentes, com navios fazendo o trajeto quinzenalmente. Além de tudo, as empresas brasileiras têm a recuperar o espaço perdido no mercado de produtos manufaturados, cujo percentual exportado caiu nos últimos anos. O Brasil está na nona posição entre os principais compradores da África, mas ocupa apenas o décimo sexto lugar entre os países que mais exportam para o continente africano. China, França, Estados Unidos, Índia, Alemanha, Itália, Espanha, África do Sul, Arábia Saudita, Coreia do Sul, Reino Unido, Japão, Holanda, Nigéria e Bélgica vendem mais para a África do que o Brasil. Uma política comercial agressiva e assertiva contribuirá para o esforço de ampliar a importância brasileira nas importações africanas. 


\section{REFERÊNCIAS BIBLIOGRAFIAS}

ABREU, M. P. Comércio Exterior: interesses do Brasil. Rio de Janeiro: Elsevier, 2007. 230 p.

ALENCASTRO, C. Dilma leva Azevêdo à África para agradecer votos na OMC. O Globo, Rio de Janeiro. 24 mai. 2013. Disponível em: <http://oglobo.globo.com/economia/dilma-levaazevedo-africa-para-agradecer-votos-na-omc-8486325>. Acesso em: 1 dez. 2013.

ALMEIDA, P. R. de. Um exercício comparativo de política externa: FHC e Lula em perspectiva. Achegas, Rio de Janeiro, n. 17, mai. 2004a. Disponível em: <http://www.achegas.net/numero/dezessete/paulo_r_a_17.htm\#sthash.EMoEQZL6.dpuf>. Acesso em: 22 jun. 2014

ALMEIDA, P. R. de. Uma política externa engajada: a diplomacia do governo Lula. Revista Brasileira de Política Internacional, Brasília, DF, v. 47, n. 1, p. 162-184, jan./jun. 2004b. Disponível em: $<$ http://www.scielo.br/scielo.php?pid=S0034$73292004000100008 \&$ script=sci_arttext>. Acesso em: 22 jun. 2014.

AMORIM, C. Brazilian foreign policy under President Lula (2003-2010): an overview. Revista Brasileira de Política Internacional, Brasília, DF, v. 53, n. spe, p. 214-240, dez. 2010. Disponível em: $<$ http://www.scielo.br/scielo.php?pid=S0034$73292010000300013 \&$ script=sci_arttext>. Acesso em: 23 jun. 2014.

ASSOCIAÇÃO DE COMÉRCIO EXTERIOR DO BRASIL. Radiografia do comércio exterior brasileiro: passado, presente e futuro. Rio de Janeiro: AEB, jan. 2012. 45 p. Disponível em: $<$ http://www.aeb.org.br/userfiles/file/AEB\%20\%20Radiografia\%20Com\%C3\%A9rcio\%20Exterior\%20Brasil.pdf>. Acesso em: 10 jan. 2015. BAUMANN, R.; OLIVEIRA, I. T. M. (Org.). Os BRICS e seus vizinhos: comércio e acordos regionais. Brasília, DF: Ipea, 2014. 472 p. Disponível em: <http://repositorio.ipea.gov.br/bitstream/11058/3186/1/livro_brics_comercio.pdf>. Acesso em: 2 mar. 2015.

BIBLIOTECA Virtual da Presidência. Disponível em: <http://www.biblioteca.presidencia.gov.br/ex-presidentes/fernando-henriquecardoso/viagens>. Acesso em: 10 mar. 2015. 
BRASIL perdoa quase US\$ 900 milhões em dívidas de países africanos. BBC Brasil.com, 25 mai. 2013a.

Disponível

em:

<http://www.bbc.co.uk/portuguese/noticias/2013/05/130520_perdao_africa_mdb. shtml>. Acesso em: 1 jul. 2013.

BRASIL. Ministério da Fazenda. Secretaria de Assuntos Internacionais. Memorando no 119/2013/SAIN/MF para Aloysio Nunes Ferreira, Senado Federal. Brasília, DF, 4 set. 2013b. p. 17-18.

BRASIL. Senado Federal. Comissão de Assuntos Econômicos. Parecer sobre a Mensagem número 40, de 2013. 2013c. Disponível em: <http://legis.senado.leg.br/mateweb/arquivos/mate-pdf/130747.pdf>. Acesso em: 1 dez. 2013. Parecer à Presidente da República.

BRASIL. Senado Federal. Comissão de Assuntos Econômicos. Parecer sobre a Mensagem número 23, de 2013. 2013d. Disponível em: <http://legis.senado.leg.br/mateweb/arquivos/mate-pdf/126023.pdf>. Acesso em: 1 dez. 2013. Parecer à Presidente da República.

BRASIL. Senado Federal. Consulta de Projetos e Matérias Legislativas. Disponível em: <http://www.senado.gov.br/atividade/Materia/>. Acesso em: 1 dez. 2013e.

BRASIL. Senado Federal. Mensagem número 36, de 2013 (n $205 / 2013$ na origem). 2013f. Disponível em: <http://www.senado.gov.br/atividade/materia/getPDF.asp?t=128692\&tp=1>. Acesso em: 1 dez. 2013.

BRASIL. Ministério do Desenvolvimento, Indústria e Comércio Exterior. Balança Comercial Brasileira: Dados Consolidados 2013. Brasília, DF, 32 p. Disponível em: < http://mdic.gov.br//arquivos/dwnl_1394635352.pdf>. Acesso em: 1 fev. 2013g.

BRASIL. Ministério do Desenvolvimento, Indústria e Comércio Exterior. Secretaria de Comércio Exterior. AliceWeb: Sistema de Análise das Informações de Comércio Exterior. Disponível em: <http://aliceweb.mdic.gov.br/>. Acesso em: 31 dez. 2014a.

BRASIL. Senado Federal. Consulta ao Sistema de Informações do Congresso Nacional (SICON). Disponível em: <http://legis.senado.gov.br/sicon/>. Acesso em: 5 jan. 2014b. 
BRASIL. Ministério do Desenvolvimento, Indústria e Comércio Exterior. Balança Comercial Brasileira: Dados Consolidados 2010. Brasília, DF, 32 p. Disponível em: < http://mdic.gov.br//arquivos/dwnl_1365786999.pdf>. Acesso em: 21 fev. 2014c.

BRASIL. Ministério do Desenvolvimento, Indústria e Comércio Exterior. Balança Comercial Brasileira: Dados Consolidados 2014. Brasília, DF, 49 p. Disponível em: <http://www.desenvolvimento.gov.br/arquivos/dwnl_1423144482.pdf>. Acesso em: 17 fev. 2015.

CABRAL, O. Dilma perdoou dívida de países africanos de olho em 2014. Veja.com, 31 mai. 2013. Disponível em: <http://veja.abril.com.br/noticia/brasil/dilma-perdoou-divida-de-paisesafricanos-de-olho-em-2014>. Acesso em: 1 jul. 2013.

CANÊDO-PINHEIRO, M. Experiências comparadas de política industrial no pós-guerra: lições para o Brasil. In: FERREIRA, P. C. et al. (Org.). Desenvolvimento Econômico: uma perspectiva brasileira. Rio de Janeiro: Elsevier, 2013. cap. 13, p. 381-404.

CARDOSO JÚNIOR, J. C. P. Inserção internacional brasileira: temas de política externa. Brasília, DF: Ipea, v. 1, livro 3, 2010. 536 p. Disponível em: <http://repositorio.ipea.gov.br/bitstream/11058/3275/1/livro03_insercaointernacional_vol1.pd f>. Acesso em: 7 jan. 2015.

CARDOSO, R. F. Politica econômica, reformas institucionais e crescimento: a experiência brasileira (1945-2010). In: FERREIRA, P. C. et al. (Org.). Desenvolvimento Econômico: uma perspectiva brasileira. Rio de Janeiro: Elsevier, 2013. cap. 6, p. 166-210.

CERVO, A. L. Relações internacionais do Brasil: um balanço da era Cardoso. Revista Brasileira de Política Internacional, Brasília, DF, v. 45, n. 1, p. 5-35, jan./jun. 2002. Disponível em: <http://www.scielo.br/pdf/rbpi/v45n1/a01v45n1>. Acesso em: 1 out. 2014.

CERVO, A. L. Inserção internacional: formação dos conceitos brasileiros. São Paulo: Saraiva, 2008. 298 p.

CMA CGM. Empresa de transporte marítimo. Disponível em: <http://www.cmacgm.com.br/site/html/rota_vasco.php?ancora=linhas>. Acesso em: 1 out.2014.

COSTA, K. P. da.; VEIGA, P. M. O Brasil frente à emergência da África: comércio e política comercial. Rio de Janeiro: Centro de Estudos de Integração e Desenvolvimento, jul. 2011, 28 
p. Disponível em: <http://www.cebri.org/midia/documentos/brasilaafricaestudon1.pdf > Acesso em: 15 jan. 2015.

FERGUSON, J. Global shadows: Africa in the neoliberal world order. Durham e Londres: Duke University Press, 2006. 262 p.

FERREIRA, P. C. et al. (Org.). Desenvolvimento Econômico: uma perspectiva brasileira. Rio de Janeiro: Elsevier, 2013. 452 p.

FONSECA, R. G. da.; MARCONINI, M. Desempenho e política comercial: inserção internacional e o comércio exterior brasileiro. Revista Brasileira de Comércio Exterior, Rio de Janeiro, n. 87, 2006.

FUNDO MONETÁRIO INTERNACIONAL. Disponível em: <http://www.imf.org/external/np/res/commod/index.aspx>. Acesso em: $31 \mathrm{dez} .2015$.

FUNDO MONETÁRIO INTERNACIONAL. DATA WAREHOUSE. Disponível em: $<$ http://elibrary-data.imf.org/DataReport.aspx $? c=1449337 \& d=33120 \& \mathrm{e}=170824>$. Acesso em: 9 jan. 2014.

GIAMBIAGI, F. et al. (Org.). Economia brasileira contemporânea: 1945-2010. 2. ed. Rio de Janeiro: Elsevier, 2011. 278 p.

GOMES SARAIVA, M. As estratégias de cooperação Sul-Sul nos marcos da política externa brasileira de 1993 a 2007. Revista Brasileira de Política Internacional, Brasília, DF, v. 50, n. 2, p. 42-59, 2007. Disponível em: <http://www.scielo.br/pdf/rbpi/v50n2/a04v50n2.pdf>. Acesso em: 29 jun. 2014.

GONÇALEZ, J. F. Nigéria. Análise Editorial, 2010. 5 p. Disponível em: $<$ http://www.analisecomercioexterior.com.br/comex06/paises/rankparceiros/nigeria/index.php >. Acesso em: 24. mai. 2010.

GONÇALVES, I. A.; MANDUCA, P. C. A organização militar e a natureza política de uma missão de paz: Um estudo de caso sobre UNAVEM III. In: XIX ENCONTRO REGIONAL DE HISTÓRIA: PODER, VIOLÊNCIA E EXCLUSÃO, 2008, São Paulo. Anais... São Paulo: USP, $2008 . \quad 1 \quad$ CD-ROM $\quad$ Disponível <http://www.anpuhsp.org.br/sp/downloads/CD\%20XIX/PDF/Autores\%20e\%20Artigos/Israel $\% 20$ Aparecido\%20Goncalves\%20e\%20Paulo\%20Cesar\%20Manduca.pdf $>$. Acesso em: 1 fev. 2015. 
GONÇALVES, R. Desenvolvimento às avessas: verdade, má-fé e ilusão no atual modelo brasileiro de desenvolvimento. Rio de Janeiro: LTC, 2013. 200 p.

GUIMARÃES, S. P. Quinhentos anos de periferia: uma contribuição ao estudo da política internacional. 5. ed. Rio de Janeiro: Contraponto, 2007. 206 p.

HAMBURG SÜD. Empresa de transporte marítimo. "Product and Service Guide". Disponível em: < http://productandserviceguide.hamburgsud-line.com/\#/152>. Acesso em 21 fev. 2015.

HIRST, M.; LIMA, M. R. S. de; PINHEIRO, L. A política externa brasileira em tempos de novos horizontes e desafios. Análise de Conjuntura OPSA, n. 12, p. 22-41, dez. 2010. Disponível

em: <http://www.opsa.com.br/images/pdf/analise/81_analises_AC_n_12_dez_2010.pdf>. Acesso em: 15 mar. 2015.

JALES, M. Inserção do Brasil no comércio internacional agrícola e expansão dos fluxos comerciais sul-sul. ICONE, 2005. 17 p. Disponível em: <http://www.lisina.com.br/upload/Inser\%C3\%A7\%C3\%A3o\%20do\%20Brasil\%20no\%20Co m\%C3\%A9rcio\%20Internacional.pdf>. Acesso em: 1 mar. 2015.

LAFER, C. Comércio e relações internacionais. São Paulo: Editora Perspectiva S. A., 1977. LAMPREIA, L. F. A política externa do governo FHC: continuidade e renovação. Revista Brasileira de Política Internacional., Brasília, DF, v. 41, n. 2, p. 5-17, jul./dez. 1998. Disponível em: <http://www.scielo.br/pdf/rbpi/v41n2/v41n2a01.pdf>. Acesso em: 25 jan. 2015.

LESSA, A. C.; OlIVEIRA, H. A. de (Org.). Parcerias Estratégicas do Brasil: a dimensão multilateral e as parcerias emergentes. Belo Horizonte: Fino Traço, v. II, 2013. 240 p.

LIMA, M. F. C.; MELO, V. D. S. de. Revalorização do lugar da África: política de desenvolvimento e as relações sul-sul no governo Lula da Silva. SÉCULO XXI, Porto Alegre, v. 1, n. 1, p. 127-55, jan-dez 2010. Disponível em: <http://sumarioperiodicos.espm.br/index.php/seculo21/article/viewFile/1709/34>. Acesso em: 10 jan. 2015.

MAIA, A. S. et al. As Relações Comerciais Brasil-África: O novo papel do Nordeste Brasileiro. Fortaleza: Expressão Gráfica e Editora, 2013. 96 p. 
MAERSK LINE. Empresa de transporte marítimo. Disponível em: <http://www.maerskline.com/pt-br/shipping-services/routenet/maersk-linenetwork/africa/wafex>. Acesso em: 1 out.2014.

NILE DUTCH. Empresa de transporte marítimo. Disponível em: $<$ https://www.niledutch.com/pt/trades-schedules/south-america-west-africa.aspx >. Acesso em: 1 out.2014.

NEGRI, J. A. de; ARAÚJO, B. C. P. O. de (Org.). As empresas brasileiras e o comércio internacional. Brasília, DF: Ipea, 2006. 416 p. Disponível em: $<$ http://www.ipea.gov.br/portal/index.php?option=com_content\&view=article\&id=5568>. Acesso em: 20 fev. 2015.

OLIVEIRA, H. A. de; LESSA, A. C. (Org.). Relações Internacionais do Brasil: temas e agendas. São Paulo: Saraiva, v. 2, 2006a. 492 p.

OLIVEIRA, H. A. de; LESSA, A. C. (Org.). Relações Internacionais do Brasil: temas e agendas. São Paulo: Saraiva, v. 1, 2006b. 356 p.

ORGANIZAÇÃO MUNDIAL DO COMÉRCIO. Banco de dados pesquisável no comércio internacional de mercadorias e serviços comerciais. Suiça. Disponível em $<$ http://stat.wto.org/StatisticalProgram/WSDBStatProgramSeries.aspx?Language=E>. Acesso em: 15 dez. 2014.

PENNA FILHO, P. África do Sul e Brasil: diplomacia e comércio (1918-2000). Revista Brasileira de Política Internacional, Brasília, DF, v. 44, n. 1, p. 69-93, jan./jun. 2001. Disponível em: <http://www.scielo.br/pdf/rbpi/v44n1/a06v44n1.pdf>. Acesso em: 17 jan. 2015.

PENNA FILHO, P. O Brasil e a África do Sul: o arco atlântico da política externa brasileira (1918-2000). Porto Alegre: FUNAG/MRE, 2008. 364 p.

PENNA FILHO, P. A parceria africana: as relações Brasil-África do Sul. Belo Horizonte: Fino Traço, 2013. 164 p.

PEREIRA, L. C. B. A crise da América Latina: consenso de Washington ou crise fiscal? Pesquisa e Planejamento Econômico, Rio de Janeiro, v. 21, n. 1, p. 3-23, abr. 1991. Disponível em: <http://ppe.ipea.gov.br/index.php/ppe/article/viewFile/883/820>. Acesso em: 10 jan. 2015. 
PIMENTEL, J. V. S. Relações entre o Brasil e a África Subsaárica. Revista Brasileira de Política Internacional, Brasília, DF, v. 43, n. 1, p. 5-23, jan./jun. 2000. Disponível em: <http://www.scielo.br/pdf/rbpi/v43n1/v43n1a01>. Acesso: 1 fev. 2015.

PIRES, M. C. (Coord.). Economia brasileira: da colônia ao governo Lula. São Paulo: Saraiva, 2010. 392 p.

PRODUTO Interno Bruto (PIB) - Taxa de Crescimento Real - Comparação entre Países. Index Mundi. Disponível em: <http://www.indexmundi.com/g/r.aspx?t=0\&v=66\&l=pt >. Acesso em: 1 jul. 2013.

RIBEIRO, C. O. Relações Político-Comerciais Brasil-África (1985-2006), 2007, 243 p. Tese (Doutorado em Ciências Políticas) - Faculdade de Filosofia, Letras e Ciências Humanas, Universidade de São Paulo, São Paulo, 2007. Disponível em: $<$ http://www.teses.usp.br/teses/disponiveis/8/8131/tde-31102007145644/publico/TESE_CLAUDIO_OLIVEIRA_RIBEIRO.pdf>. Acesso em: 1 mar. 2015.

RIBEIRO, C. O. Adjustment Changes: A Política Africana do Brasil no Pós-Guerra Fria. Revista de Sociologia e Política, Curitiba, v. 18, n. 35, p. 55-79, 2010. Disponível em: <http://www.scielo.br/pdf/rsocp/v18n35/v18n35a05.pdf>. Acesso em: 23 jun. 2014.

RIZZI, K. R. Relações Brasil-Angola no Pós-Guerra Fria (1990-2002). Anos 90, Porto Alegre, v. $15, \quad$ n. $27, \quad$ p. 287-324, jul. 2008. Disponível em: <http://www.ufrgs.br/ppghist/anos90/27/27art9.pdf>. Acesso em: 25 jan. 2015.

SANTANA, I. de. Relações econômicas Brasil-África: A Câmara de comércio afro-brasileira e a intermediação de negócios no mercado africano. Estudos Afro-Asiáticos, Rio de Janeiro, v. 25, n. 3, p. 517-555, 2003. Disponível em: <http://www.scielo.br/pdf/eaa/v25n3/a06v25n3.pdf>. Acesso em: 19 jan. 2015.

SANTOS, M. Por uma outra globalização: do pensamento único à consciência universal. 11 . ed. Rio de Janeiro: Record, 2004. 178 p.

SARAIVA, J. F. S. (Org.). Comunidade dos Países de Língua Portuguesa (CPLP): Solidariedade e ação política. Brasília, DF: IBRI, 2001. 208 p.

SARAIVA, J. F. S. Política exterior do governo Lula: o desafio africano. Revista Brasileira de Política Internacional, Brasília, DF, v. 45, n. 2, p. 5-25, jul./dez. 2002. Disponível em: <http://www.scielo.br/pdf/rbpi/v45n2/a01v45n2.pdf>. Acesso em: 22 jun. 2014. 
SARAIVA, J. F. S. A busca de um novo paradigma: política exterior, comércio externo e federalismo no Brasil. Revista Brasileira de Política Internacional, Brasília, DF, v. 47, n. 2, p. 131-162, 2004. Disponível em: <http://www.scielo.br/scielo.php?pid=S0034$73292004000200005 \&$ script=sci_arttext $>$. Acesso em: 7 fev. 2015.

SARAIVA, J. F. S. A África na ordem internacional do século XXI: mudanças epidérmicas ou ensaios de autonomia decisória? Revista Brasileira de Política Internacional, Brasília, DF, v. 51, n. 1, p. 87-104, 2008a. Disponível em: <http://www.scielo.br/scielo.php?pid=S003473292008000100005\&script=sci_arttext>. Acesso em: 29 jun. 2014.

SARAIVA, J. F. S. África parceira do Brasil atlântico: relações internacionais do Brasil e da África no início do século XXI. Belo Horizonte: Fino Traço, 2012. 168 p.

SARAIVA, J. F. S. (Org.). História das relações internacionais contemporâneas: da sociedade internacional do século XIX à era da globalização. São Paulo: Saraiva, 2008b. 348 p.

SARAIVA, J. F. S.; CERVO, A. L. (Org.). O crescimento das Relações Internacionais no Brasil. Brasília, DF: IBRI, 2005. 308 p. Disponível em: $<$ http://funag.gov.br/loja/download/265-

Crescimento_das_Relacoes_Internacionais_no_Brasil_O.pdf>. Acesso em: 18 mar. 2015.

SARAIVA, J. F. S. O lugar da comunidade dos países de língua portuguesa (CPLP) na inserção internacional do Brasil. 2001. 26 p. Disponível em: $<$ http://portal.anpocs.org/portal/index.php?option=com_docman\&task=doc_view\&gid=4606 \&Itemid=356>. Acesso em: 25 jan. 2015.

SARAIVA, M. G. As estratégias de cooperação Sul-Sul nos marcos da política externa brasileira de 1993 a 2007. Revista Brasileira de Política Internacional, Brasília, DF, v. 50, n. 2, p. 42-59, 2007. Disponível em: <http://www.scielo.br/pdf/rbpi/v50n2/a04v50n2.pdf>. Acesso em: 29 jun. 2014.

SATO, E. Economia e política das relações internacionais. Belo Horizonte: Fino Traço, 2012. 236 p.

SAVASINI, J. A. A.; MALAN, P. S.; BAER, W. (Org.). Economia internacional. São Paulo: Saraiva, 1979. $558 \mathrm{p}$. 
SEIBERT, G. Brazil in Africa: Ambitions and Achievements of an Emerging Regional Power in the Political and Economic Sector. Lisboa: Instituto Universitário de Lisboa, Centro de Estudos Africanos, 2011. 16 p. Disponível em: <http://aegis-eu.org/archive/ecas4/ecas4/panels/1-20/panel-8/Gerhard-Seibert-Full-paper.pdf>. Acesso em: 1 jul. 2013.

SILBER, D. S. Tendências da Economia Mundial e da Economia Brasileira. São Paulo: Fipe, 2010.

SILVA, H. C. M. da. Da maturidade do desenvolvimento à consolidação do Modelo Substitutivo de Exportações: (1964-1989). In: SARAIVA, J. F. S.; CERVO, A. L. (Org.). O crescimento das Relações Internacionais no Brasil. Brasília, DF: IBRI, 2005. p. 285-295. Disponível em: $<$ http://funag.gov.br/loja/download/265-

Crescimento_das_Relacoes_Internacionais_no_Brasil_O.pdf $>$. Acesso em: 18 mar. 2015.

SUPLICY, E. Fazer Prevalecer o Progresso com a Solidariedade. Jornal do Brasil, Brasília, 3 set. $2004 . \quad$ Disponível em: $<$ http://www.senado.gov.br/senadores/Senador/esuplicy/Publicacoes/artigos/artigo.asp?data=0 3/09/2004\&codigo=2299>. Acesso em: 1 dez. 2013.

SZKLARZ, E. A ascensão do Brasil: os dois lados da realidade. Nueva Sociedad especial em português,. p. 4-21, dez. 2010. Disponível: < http://library.fes.de/pdf-files/nuso/ep-2010.pdf > . Acesso em: 1 fev. 2014.

ULHÔA, R. Contestado por oposição, perdão à dívida do Congo é aprovado no Senado. Valor Econômico, São Paulo, 10 jul. 2013. Disponível em: <http://www.valor.com.br/politica/3194280/contestado-por-oposicao-perdao-divida-docongo-e-aprovado-no-senado\#ixzz2ZMMHTtNk>. Acesso em: 1 jul. 2013.

VELLOZO JÚNIOR, J. O crescimento das Relações Internacionais no Brasil, Revista Brasileira de Política Internacional, Brasília, DF, v. 48, n. 2, p. 221-223, jul./dez. 2005. Disponível em: $\quad$ <http://www.scielo.br/scielo.php?pid=S003473292005000200014\&script=sci_arttext $>$. Acesso em: 18 mar. 2015.

VIEIRA, M. B. B. The semi-periphery in Africa: the case of Brazil. In: ECAS 2011 - 4TH EUROPEAN CONFERENCE ON AFRICAN STUDIES, 2011, Uppsala. Panel 8: South-South Dialogue: BRIC s African Agenda, 2011. Disponível em: <http://www.aegiseu.org/archive/ecas4/ecas-4/panels/1-20/panel-8/Maira_-_First_draft-(3).pdf>. Acesso em: 4 dez. 2013. 